Aus dem Institut für Tierzucht und Haustiergenetik der Georg-August-Universität Göttingen

\title{
In-vitro-Maturation porciner Oozyten auf Feederlayer-Kulturen mit Antikörpern gegen Inhibin
}

Dissertation

zur Erlangung des Doktorgrades der Fakultät für Agrarwissenschaften der Georg-August-Universität Göttingen

vorgelegt von

Manuela Ropeter-Scharfenstein

geboren in Altenkirchen/Westerwald

Göttingen, im Mai 1999 
Referent:

Prof. Dr. W. Holtz

Korreferent:

Prof. Dr. H. W. Michelmann

Tag der mündlichen Prüfung: 20. Mai 1999 
Für meine Eltern, Henning und Lisa-Marie 


\section{Inhaltstverzeichnis}

Übersicht der verwendeten Abkürzungen

2.1. Oozytentwicklung in vivo und in vitro

2.1.1. Oogenese und Follikulogenese

2.1.1.1. Oogenese (Eizellbildung)___ 5

2.1.1.2. Follikulogenese __ 6

2.1.2. Nukleus- und Zytoplasmareifung___ 7

2.1.2.1. Inhibin als lokaler Regulator der Follikulogenese ___ 10

2.2. Maturation in vitro ___ 11

2.3. Mechanismen, die den meiotischen Block der Oozyten beenden _____ 13

2.4. Gewinnung und Selektion der Kumulus-Oozyten-Komplexe __ 14

2.5. Spermatozoenreifung _ 15

2.5.1. Kapazitation mit anschließender Akrosomenreaktion __ 15

2.5.2. In-vitro- Kapazitation beim Schwein ___ 16

2.6. Reifung, Befruchtung und Kultur porciner Oozyten in vitro ___ 17

2.7. Anforderungen und Möglichkeiten der frühen Embryokultur ___ 22

2.7.1 1. Energetische Versorgung ___ 24

2.7.1.1.1. Aminosäuren 224

2.7.1.1.2. Glucose und Phosphat _ 25

2.7.1.1.3. Serumalbumin 225

2.7.1.1.4. Wachstumsfaktoren __ 26

2.8. Proteinzusätze ___ 26

2.8.1. Follikelflüssigkeit __ 26

2.9. Kultursysteme __

2.9.1. Kokultursysteme 28

2.9.1.1. Eileiterfeederzellen als Kokultur 229

2.9.1.2. Buffalo-Rat-Liver-Zellen als Feederlayer ___ 31

2.10. Beurteilungsmöglichkeiten der Embryonenqualität _____ 31

2.10.1. Morphologische Beurteilung _ 31

2.10.2. Beurteilung durch Essisäure/Alkohol-Präparation___ 31

2.10.3. Fluoreszenzfärbung mit Hoechst A 33342

2.10.4. Fluoreszenzfärbung mit FDA __ 32

3.0. Material und Methoden ___ 33

3.1.Tiermaterial ___ 33

3.2. Medien ____ 33

3.2.1. Transport - und Waschmedium für Ovarien und Oozyten ___ 33

3.2.2. Maturationsmedium _ 35

3.2.3. Waschmedium für Spermatozoen __ 36

3.2.4. Kapazitationsmedium __ 36

3.2.5. Befruchtungsmedium_— 36

3.2.6. Medien der frühen Embryokultur __ 36

3.2.6.1. NCSU-23 _ 37

3.3. Eigene Untersuchungen zur In-vitro-Maturation porciner Oozyten___ 37

3.4. Gewinnung der Oozyten______ 38

3.4.1. Klassifizierung der Kumulus - Oozyten - Komplexe___ 39 
3.5. Proteinquellen __ 39

3.5.1. Fetales Kälberserum (FKS) _ 39

3.5.2. Porcine Follikelflüssigkeit

3.5.3. Nicht Hitze-inaktiviertes Ziegenserum __ 40

3.5.4. Gewinnung des Anti-hInhibin- $\alpha$ Ziegenserums ___ 40

3.6. Einfluß von fetalem Kälberserum (Versuch 1) _ _ 41

3.6.1. Fixierung und Giemsa-Färbung gereifter Oozyten __ 42

3.7. Einfluß von Anti-hInhibin $\alpha$ Ziegenserum (Versuch 2) ___ 43

3.8. Einsatz porciner Follikelflüssigkeit als Basisproteinquelle für Anti hInhibin- $\alpha$

Ziegenserum (Versuch 3) 46

3.8. 1. Fixierung und Färbung der Oozyten mit Lacmoid ___ 47

3.9. Herstellung von Feederlayern ___ 51

3.9.1. Gewinnung der Eileiterzellen für die Feederlayerkultur ___ 51

3.9.1.1. Herstellung der Eileiter - Feederlayer __ 52

3.9.2. Herstellung der Buffalo-Rat-Liver-Feederlayer __ 52

3.10. Einsatz von Eileiter- und Buffalo-Rat-Liver-Feederlavern (Versuch 4) ____ 52

3.11. Eigene Untersuchungen zur In-vitro-Fertilisation in vitro gereifter Oozyten.___ 54

3.11.1. Spermagewinnung ___ 54

3.11.2. Spermaaufbereitung _ 55

3.11.3. Befruchtung der Oozyten___ 55

3.11.4. Die frühe Embryokultur

3.12. Untersuchung der zytoplasmatischen Reife mit Anti- hInhibin- $\alpha$ Ziegenserum gereifter Oozyten durch in-vitro-Fertilisation (Versuch 5)

3.13. Untersuchung der zytoplasmatischen Reife auf Feederlayern gereiften Oozyten durch in-vitro-Fertilisation (Versuch 6)

3.14. Untersuchung von Maturation und Kultur auf Feederlayern in-vitro gereifter und $\begin{array}{ll}\text { fertilisierter Oozyten (Versuch 7)_______ } & 57\end{array}$

3.14.1 Beurteilung der frühen Embryonalstadien ___ 57

3.14.1.1. Morphologische Beurteilung ___ 57

3.14.1.2.Kombinierte FDA- Hoechst-Färbung zur Bestimmung der

Zytoplasmaaktivität

Abb. 9: Mit FDA angefärbte Oozyte. Die hellgrüne Fluoreszenzreaktion weist auf ein enzymatisch aktives

Zytoplasma einer vitalen Oozyte hin

Abb. 10: Mit Hoechst A 3342 angefärbte Zygote. Das Zytoplasma mit Zellkernen (Pfeile) ist bei der Präparation ausgelaufen. Deutlich zu erkennen sind anheftende Spermatozoen an der Zona pellucida

(kleine Pfeile) (Balken $=50 \mu \mathrm{m})$.

Abb. 11: Kombinierte FDA (grün) und Hoechst A 33342 (blau)-Färbung eines Embryos mit drei

Zellkernen (kleine Pfeile)

3.15. Interaktion von Eileiterfeederlayern in Maturation und Kultur porciner Oozyten und Embryonen

(Versuch 8)

3.16. Untersuchung zur Entwicklungsfähigkeit Eileiterfeederlayer-kultivierter Oozyten

(Versuch 9) _______ 61

3.17. Übertragung von 2 Tage alten Embryonen auf Empfängersauen ____ 63

3.17 .1 Embryotransfer ___ _ 63

3.13. Statistische Auswertung _ _ 64

4. Ergebnisse _ _ 65

4.1. Reifung follikullärer Oozyten des Schweines in unterschiedlichen Konzentrationen etalen Kälberserums (FKS) (Versuch 1). 65

4.2. In-vitro-Reifung porciner Oozyten mit Anti - hInhibin- $\alpha$ Ziegenserum und

hitzeinaktiviertem Ziegenserum als Proteinquelle (Versuch 2). 
4.3. In-vitro-Reifung porciner Oozyten mit Anti - hInhibin- $\alpha$ und porciner

Follikelflüssigkeit als Proteinquelle (Versuch 3). 66

4.4. In-vitro-Reifung von Schweineoozyten auf Feederlayern (Versuch 4).

4.5. In-vitro-Befruchtung von Oozyten, die mit einem antikörperhaltigen Ziegenserum in porciner Follikelflüssigkeit gereift wurden (Versuch 5).

4.6. In-vitro-Befruchtung von Oozyten, die mit einem antikörperhaltigen Ziegenserum in porciner Follikelflüssigkeit und zusätzlich auf Eileiter- bzw. BRL- Feederlayern gereift wurden (Versuch 6).

4.7. Einfluß von Eileiter- und BRL- Feederlayern in Kombination verschiedener

Konzentrationen Anti-hInhibins- $\alpha$ oder nicht hitzeinaktiviertem Ziegenserum während der Maturation auf Teilung, Vitalität und Kernmaterial porciner Oozyten nach Befruchtung (Versuch 7).

4.8. Einsatz von Eileiter- und BRL Feederlayern in Maturation porciner Oozyten sowie anschließender Kultur der resultierenden Embryonen nach In-vitro-Fertilisation (Versuch 8). 81

4.9. Eileiterfeederlayer während der In-vitro Maturation und Kultur porciner Ozyten und Embryonen im Vergleich zu in vivo gereiften und in vitro befruchteten Oozyten und Embryonen auf Eileiterfeederlayern mit anschließendem Embryotransfer auf Empfängersauen (Versuch 9). 83

5.0.Diskussion __ 86

5.1. Gewinnung der Ovarien und Oozyten 86

5.2. In-vitro-Maturation porciner Oozyten mit einem Antikörper gegen Inhibin, Eileiterund Buffalo-Rat-Liver - Feederlayern 88

5.3.In-vitro-Entwicklung in vitro gereifter und befruchteter Oozyten 93

5.4. Beurteilungskriterien porciner Embryonen 97

6.0. Zusammenfassung 100

7.0. Summary 104 


\section{Übersicht der verwendeten Abkürzungen}

AnaI

Anti - INH.

ATP

bFGF

BRL

BSA

cAMP

CSF

Da

DMEM

$\mathrm{E}_{2}$

FDA

FKS

FSH

G2-Phase

GV

GVBD

HEPES

IBMX

IGA

IGF

LIF

MI

MII

MIS

MPF

MPGF

M-Phase

$\mathrm{M}_{\mathrm{r}}$

MSA

NCSU23

OMI

PBS
Anaphase I

nicht hitzeinaktiviertes inhibinantikörperhaltiges Ziegenserum

Adenosin Triphosphat

basic Fibroblast Growth Factor

Buffalo Rat Liver

Bovine serum albumin

cyklisches Adenosin $\underline{\text { Monophosphat }}$

Cytostatischer Faktor

Dalton

Dulbecco`s Modified Eagle $\underline{\text { Medium }}$

Östradiol

3`6 - Fluorescein-Diacetyl

Fetales Kälberserum

Follikel $\underline{\text { Stimulierendes Hormon }}$

Gap (Zellzyklus)

Germinales vesiculum; Keimbläschen

Germinal Vesicle Breakdown

eine N-2-Hydroxyethyl piperazin $\mathrm{N}^{\prime}-2$ ethansufat $\underline{\text { Säure }}$

Isobutylmethyl-ㅁanthin

Immunglobulin $\underline{\mathrm{A}}$

Insulin-like Growth Factor

Leukaemia Inhibitory Factor

Metaphase I

Metaphase II

Meiosis Inducing $\underline{\text { Substance }}$

Maturation promoting Factor

Male Pronucleus Growth factor

Mitose (Zellzyklus)

Molekülgewicht

Multiplication Stimulating Activity

North $\underline{\text { Carolina }}$ State University

Oocyte Meiosis Inhibitor

Phosphate Buffered Saline 
PDGF

$\mathrm{pFF}$

PMSG

Promet I

SD

TCM199

TeloI

TGF

ZS

ZS ak.
Platelated Derived Growth Factor

porcine Follikelflüssigkeit

Pregnant $\underline{\text { Mare }}$ Serum Gonadotrophin

Prometaphase I

Standardabweichung

Tissue $\underline{\text { Culture }}$ Medium 199

Telophase I

Transforming Growth Factor

Ziegenserum

Nicht hitzeinaktiviertes Ziegenserum 


\section{Einleitung}

Die In-vitro-Fertilisation (IVF) im Rahmen moderner Biotechnologien ist in manchen Bereichen der Nutztierzucht bereits aus der experimentellen Phase in eine praxisbezogene Anwendung übergegangen. Nachdem BERG (1993) für die In-vitroProduktion für Rinderembryonen ein vollständiges Arbeitsprotokoll entwickelt hat, das sowohl eine In-vitro-Maturation (Reifung) mit anschließender Fertilisation als auch eine Embryonenkultivierung ermöglichte, war aufbauenden Biotechnologien der Weg geebnet. Auch für die Kleinen Wiederkäuer wie Schaf und Ziege existieren Systeme zur Erstellung von Embryonen in vitro (PEREIRA et al., 1995). Dagegen bestehen für eine In-vitro-Maturation von unreifen Oozyten beim Schwein noch Probleme. In vivo gereifte Oozyten können in vitro befruchtet und erfolgreich zu Embryonen kultiviert werden, während in vitro gereifte Oozyten kaum Embryonalstadien hervorbringen

Die physiologische Maturation von Schweineoozyten ist die Basis für eine erfolgreiche Embryonenproduktion. Zu Beginn einer In-vitro-Fertilisation werden unreife Oozyten aus Antralfollikeln gewonnen. Mit dieser Entnahme tritt ein spontanes Ende des meiotischen Ruhestadiums der Oozyte ein, die in der Prophase I im DiktyotänStadium arretiert wurde. Nach Vollendung der Prophase I im Diakinese-Stadium folgen Metaphase I, Anaphase und Telophase I. Im günstigsten Fall wird die Meiose dann weiter bis zur nuklearen Reife der Oozyte, d. h. dem Erreichen der Metaphase II weitergeführt. Trotz dieser erreichten Kernreifung resultiert aus der nicht abgeschlossenen Reifung des Zytoplasmas nur eine geringe Entwicklungskompetenz der Oozyten, wenn sie befruchtet werden. Ferner ist das In-vitro-Milieu nicht adäquat die Vitalität der Oozyten zu erhalten und einen gesunden Embryo hervorzubringen.

Oft wurde bislang bei Schweineoozyten auf eine In-vitro-Maturation verzichtet und mit in vivo gereiften Oozyten gearbeitet (RATH et al., 1993). So ist es möglich nach IVF späte Embryonalstadien (Morulae und Blastozysten) des Schweines in vitro zu erzeugen, um Embryonen für weitere Untersuchungen zu liefern. Allerdings müssen für die Gewinnung dieser Oozyten Jungsauen hormonell stimuliert werden, was sowohl mit erhöhten Kosten als auch vermehrtem Arbeitsaufwand verbunden ist Am Schlachthof fallen Schweineovarien ständig an, so daß eine schnelle und kostengünstige Beschaffung einer großen Anzahl unreifer Oozyten möglich ist. Allerdings bedürfen diese Oozyten der In- vitro- Maturationsphase, um Befruchtungskompetenz zu erlangen. 
In dieser Arbeit lag das Hauptaugenmerk auf einer Optimierung der In-vitroMaturation (IVM) der Oozyten aus präovultorischen Follikeln. Ziel dieser Untersuchung war, durch Supplementierung von Antikörpern gegen das Hormon Inhibin (Anti-hInhibin- $\alpha$ ) im In-vitro-System an Oozyten gebundenes Inhibin abzufangen und somit eine ungehinderte Kernreifung in der Oozyte zu ermöglichen. Dabei sollte eine synchrone nukleare und zytoplasmatische Reifung der Oozyten erzielt werden. Im Verlauf dieser Arbeit wird dieser Antikörper als Anti-INH bezeichnet. Als weiteres Ziel dieser Arbeit wurde die Erhaltung der Vitalität von porcinen Oozyten und Embryonen angesehen. Feederlayer-Systeme wurden hierfür sowohl in der IVM als auch bei der anschließenden Kultivierung eingesetzt.

Mit Hilfe des Antikörpers gegen das reifungshemmende Hormon Inhibin und unter Einsatz verschiedener Feederlayersysteme in der In-vitro- Maturationsphase wurden Reifungs- und Befruchtungserfolge ermittelt. Zur Beurteilung von Reifung und Befruchtung wurden Färbeverfahren und morphologische Klassifizierungen herangezogen.

\section{Literaturübersicht}

\subsection{Oozytentwicklung in vivo und in vitro}

Die Follikel- und Oozytenentwicklung stehen in einer gegenseitigen Wechselbeziehung. Diese Entwicklung verläuft allerdings auf sehr unterschiedlichen Ebenen. Im Folgenden soll die Entstehung der Oozyte selbst, des Follikels sowie der Follikelzellen betrachtet werden. Bei der Oozytentwicklung stehen die nukleare, die zytoplasmatische und die Kumulusreifung im Vordergrund. Alle Entwicklungsvorgänge unterliegen in vivo einer hormonellen Steuerung.

\subsubsection{Oogenese und Follikulogenese}

Die Differenzierung der Oozyte und des Follikels finden synchron statt und bilden zusammen eine funktionelle Einheit. Während bei der Oogenese Differenzierung, Wachstum und Reifung im Vordergrund stehen, hat der Follikel die Aufgabe, die sich entwickelnde Oozyte zu beherbergen und zu ernähren, während er ebenfalls wächst und sich differenziert. 


\subsubsection{Oogenese (Eizellbildung)}

Oozyten haben im Vergleich zu anderen somatischen Zellen des Körpers eine enorme Größe. Mit einem Durchmesser von 80-220 um beim Menschen (MICHELMANN et al.,

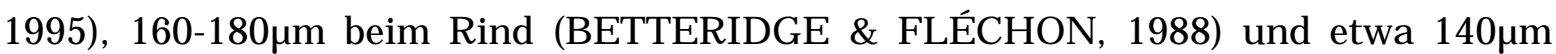
beim Schwein (MOTLIK \& FULKA, 1986) stellen sie die volumenmäßig größten Zellen des Körpers dar. Als weitere Besonderheit sind Oozyten von einer Glykoproteinschicht, der sogenannten Zona pellucida, umgeben. Diese dient zum einen als Schutz vor mechanischen Einwirkungen, zum anderen als Barriere für artfremde Spermien. Der Ursprung dieser Barriere ist vermutlich bei den Meerestieren mit einer extrakorporaler Befruchtung zu suchen, denn im Wasser sind die Eier direkt mechanischen Einflüssen und artfremden Spermien ausgesetzt (ALBERTS et al., 1990).

Die Oogenese beginnt bereits im fetalen Entwicklungsstadium, endet aber erst beim geschlechtsreifen Individuum. Bei der Entwicklung von der Oogonie bis zur befruchtungsfähigen Oozyte kommt es zu Zellproliferationen, Änderungen der Chromosomenkonstellationen sowie biochemischen Veränderungen.

Bereits in der ganz frühen pränatalen Phase eines Säugetieres differenzieren sich primordiale Urkeimzellen zu Vorläufern der weiblichen Gameten, den Oogonien, die zu ihren Zielgonaden (Ovarien) wandern und mit einer mitotischen Proliferation beginnen. Nach der mitotischen Vermehrungsphase treten die Oogonien in die erste meiotische Teilung, der sogenannten Reduktionsteilung, ein. Die nun als primäre Oozyten bezeichneten Eizellen durchlaufen die fünf Stadien der Prophase I (Leptotän, Zygotän, Pachytän, Diplotän, Diakinese), um zwischen dem Diplotän und DiakineseStadium, im sogenannten Diktyotän (Stadium des Germinalen Vesiculums, GV), ihre weitere Entwicklung vorläufig einzustellen. So wird bis zum Eintritt der Pubertät die Meiose I durch Arretierung unterbrochen. In den primären Oozyten hat bis zur Diakinese das Crossing over der Chromosomen bereits stattgefunden, und die Chromosomen verharren in despiralisierter Form bis zur Geschlechtsreife des Individuums. Die Oozyte, die zu diesem Zeitpunkt einen großen Kern, das germinale Vesiculum (= GV, Keimbläschenstadium) besitzt, verharrt in diesem Stadium bis die Meiose in der präovulatorischen Phase des Säugetieres wieder aufgenommen wird.

Diese verlängerte Prophase I wird zur Synthese essentieller Komponenten für die Oozyte genutzt. Die primären Oozyten synthetisieren die azellulläre glykoproteinhaltige Hülle, die Zona pellucida (BLEIL \& WASSARMAN 1980; DUNBAR et al., 1994). DNA-assoziierte Proteine wie Histon H4 und die Mikrotubuli 
der Metaphasespindel aufbauendes Tubulin (MOOR et al., 1983) sowie Rindengranulae werden in der primären Oozyte angereichert. Durch Bindung von Histonen an die DNA eintstehen Nucleosomen, die Grundpartikel des Chromatins. Histon H4 bildet mit Histon H3 den inneren Kern eines Nucleosoms. Weiterhin akkumulieren die primären Oozyten Ribosomen, Glykogen, Lipide und mRNA, die die spätere Proteinsynthese steuert und für die in den frühen Entwicklungsstadien benötigten Proteine codiert (MOORE \& LINTERN-MOORE, 1987; KAPLAN et al., 1982; BACHVAROVA et al., 1985). Diese Vorgänge sind Vorbereitungen für die Embryonalentwicklung (BACHVAROVA \& DE LEON, 1977). Während sich Histon H4 und die ribosomalen Proteine innerhalb des Nukleus akkumulieren, verbleibt das Tubulin im zytoplasmatischen Teil der Oozyte (WASSARMAN \& MROZAK, 1981, WASSARMAN et al., 1981). Die Histone sind für die frühe Embryonalentwicklung notwendig, um zu Beginn der ersten Teilungen und den damit verbundenen schnellen DNA-Synthesen bereitzustehen (MOOR et al., 1983).

\subsubsection{Follikulogenese}

Zum Zeitpunkt der Geburt sind die meisten primären Oozyten von einer einfachen Epithelschicht umgeben und bilden den Primär- oder Primordialfollikel (EPPIG, 1991). Diese Follikelzellen vermehren sich durch mitotische Proliferation zu einer mehrlagigen Kumulusschicht. Die innere Granulosaschicht baut sich säulenartig auf der Zona pellucida auf und wird als Corona radiata bezeichnet. Durch die Sekretion der Granulosazellen bildet sich Follikelflüssigkeit, der Liquor folliculli. So entsteht durch die Flüssigkeitseinlagerung ein Hohlraum im Granulosaepithel, das Antrum folliculi. Im anschließenden Stadium des Sekundärfollikels entwickelt sich das vielschichtige Stratum granulosum um das sich die zweischichtige Theka folliculi bestehend aus Theka interna (innen) und Theka externa (außen) heranbildet. Das Wachstum des Tertiärfollikels wird durch das follikelstimulierende Hormon (FSH) aus dem Hypophysenvorderlappen angeregt. Durch weitere Flüssigkeitseinlagerungen reift der Tertiär- zum Graaf schen Follikel heran. Die Follikelzellen, die die Oozyte umgeben, bleiben erhalten und bilden den Kumulus oophorus. Die Theka interna besteht aus endokrin aktivem Gewebe mit der Fähigkeit zur Steroidsynthese (Östrogenproduktion). Die Follikelflüssigkeit, eiweißreich und hormonhaltig, ähnelt in der chemischen Zusammensetzung und Osmolarität dem Blutplasma (MÉNÉZO \& TESTART, 1975, GOSDEN \& HUNTER, 1988).

Die Zellen der Corona radiata durchdringen die Zona pellucida durch einen oder mehreren zytoplasmatische Fußfortsätze, die durch einen knollenartigen Knopf das 
zytoplasmatische Oolemma nur berühren (Maus, Hamster, Ratte) oder in das periphere Oolemma eingestülpt sind (Kaninchen, Kuh, Schaf) (GILULA et al., 1978; MOTLIK \& FULKA, 1986; THIBAULT et al., 1987).

Die Follikelzellen kommunizieren mit der Oozyte über Gap- Junctions. Die Gap Junctions wurden 1976 von ANDERSON und ALBERTINI mittels Elektronenmikroskopie entdeckt. Gap junctions bestehen aus Transmembranproteinen. Sie bilden Strukturen, die man Connexons bezeichnet. Wenn sich die Connexons in den Plasmamembranen zweier aneinandergrenzender Zellen gegenüberstehen, bilden sie einen durchgehenden wäßrigen Kanal, der die beiden Zellinnenräume verbindet. Die Connexons verbinden sich dabei so, daß die zugehörige Plasmamembran durch eine Lücke (gap) getrennt ist. In elektronenmikroskopischen Aufnahmen, die mit der Gefrierbruchmethode erstellt wurden, erkennt man die Connexons als Intramembranpartikel. Jede Gap Junction kann mehrere hundert derartig zusammengelagerte Connexos enthalten (ALBERTS et al., 1990). Sie erlauben den Austausch von Aminosäuren, Nukleosiden und Phospholipidvorläufern nicht aber von Makromolekülen. Neben dieser Ernährungsfunktion synthetisieren die Follikelzellen Faktoren, die einen steuernden Einfluß auf die Weiterentwicklung des Zellkernes der Oozyte ausüben (STAIGMILLER \& MOOR, 1984).

Mit der Auflösung der interzellulären Verbindungen der Kumulus-Granulosaschicht während der Oozyten- und Follikelreifung durch Einlagerungen von Hyaluronsäure geht eine Unterbrechung der Kommunikation zwischen Oozyte und follikulären Zellen einher. Diese morphologischen Veränderungen stehen in einem engen kausalem Zusammenhang mit der Wiederaufnahme der Meiose in der Oozyte.

\subsubsection{Nukleus- und Zytoplasmareifung}

Mit Eintritt der Pubertät werden in zyklischen Abständen jeweils mehrere Follikel rekrutiert und selektiert, damit deren Oozyten die Meiose wieder aufzunehmen und in die letzte Reifungsphase oder Maturation eintreten. Es handelt sich hierbei um Prozesse, bei denen Hormone über die entsprechenden Rezeptoren an den Granulosazellen auf die Oozyten einwirken. Sehr frühe Untersuchungen von PINCUS \& ENZMANN (1935) zeigen, daß neben diesem hormonellen Stimulus zur Wiederaufnahme der Meiose auch isolierte Oozyten aus Antralfollikeln spontan die Meiose wieder aufnehmen können.

$\mathrm{Zu}$ Beginn des Zyklus geht eine Gruppe an zuvor rekrutierten und selektierten Follikeln, die bereits auf kleine Anstiege von FSH (Follikelstimulierendes Hormon) im 
Serum antworten, ins präantrale Stadium über. In dieser Phase besitzen die Follikel schon mehrere Granulosazellschichten. Die Rezeptoren für FSH in den Granulosazellen vervielfältigen sich und die Granulosazellen beginnen mit der Sekretion von Östradiol-17-Beta $\left(\mathrm{E}_{2}\right)$ durch die Aromatisierung von Androgenen, die von den Theka Zellen geliefert werden. $\mathrm{E}_{2}$ und FSH gemeinsam sorgen für eine weitere Proliferation der Granulosazellen und Zunahme der FSH-Rezeptoren an der Granulosazellplasmamembran (HAFEZ, 1980; TROUNSON \& GARDNER, 1993). Die Auswahl- und Steuerungsmechanismen zur Selektion sowie der Rekrutierung der Follikel bis zur Bestimmung des dominanten Follikels sind bis heute noch nicht vollständig geklärt. Man vermutet einen inhibinabhängigen Rückkopplungsmechanismus zu FSH (vgl. Kap. 2.1.2.1.). Der dominante Follikel ist in der Lage, Androgene in Östrogene umzuwandeln. Die anderen rekrutierten Follikel wachsen nicht mehr heran und gehen in Atresie über. Intraovarielle Wachstumsfaktoren wie der Insulin-like-growth factor (IGF), Epidermal growth factor (EGF) und die Inhibin-Familie werden für die Regulation des Prozesses der Follikeldominanz und Atresie verantwortlich gemacht. Der dominante Follikel wächst beständig weiter und sezerniert kontinuierlich $\mathrm{E}_{2}$ und Inhibin, die einen negativen Feedback auf die FSH-Produktion und somit auf ein Absinken des FSH Spiegels im Serum nach sich ziehen (TROUNSON \& GARDNER, 1993).

Die Oozyte im Tertiärfollikel hat die Meiose I bis zur Metaphase II fortgesetzt und bleibt nach der Ovulation bis zur Befruchtung in diesem Stadium arretiert. Oozyten müssen, um eine vollständige Befruchtungsfähigkeit zu erlangen, synchron sowohl eine nukleare als auch zytoplasmatische Reifung vollenden. Eine Oozytenreifung auf nuklearer Ebene umfaßt die Auflösung der Kernmembran (Germinal vesicle breakdown=GVBD), die Kondensierung des Chromatins zu getrennten Bivalenten und die Verteilung der homologen Chromosomenpaare auf Oozyte und Polkörperchen in der ersten meiotischen Teilung (Mc GAUGHEY et al., 1979).

Die Entwicklung der Oozyte vom Diktyotänstadium bis zum befruchtungsfähigen Ei in der Metaphase II wird als meiotische Maturation bezeichnet. Nur Oozyten, die 80\% ihrer endgültigen Größe erreicht haben (WASSARMAN et al., 1981; THIBAULT et al., 1987; SZÖLLÖSI, 1993), sind in der Lage, die Arretierung im Diktyotänstadium aufzuheben und den Übergang im Zellzyklus aus der G2 in die M Phase zu erreichen (CYERT \& KIRSCHNER, 1988; LABBE et al., 1989). Diese Eigenschaft der Oozyten wird als meiotische Kompetenz bezeichnet (THIBAULT et al., 1987; SZÖLLÖSI, 1993, HIRAO et al., 1994). Sie tritt nur ein, wenn die Regulation durch einen zytoplasmatischen Faktor, den sogenannten Maturation Promoting Factor (MPF), 
erfolgt. Als erste berichteten MATSUI und MARKERT (1971) über die Existenz dieses proteinartigen, zytoplasmatischen Faktors. Sie injizierten diese Substanz in die Oozyten von Xenopus laevis und erzeugten damit eine Chromosomenkondensation, die Auflösung der nuklearen Membran und eine Formation zweier meiotischer Spindeln (FULKA et al., 1994), d.h die gleichen Effekte, wie sie auch mit Progesteron entstehen würden.

Folglich ist der MPF für den Austritt aus der meiotischen Prophase verantwortlich (EVANS et al., 1983). Der MPF hat eine entscheidene Funktion bei der normalen Zellteilung, da er den Übertritt der Zellen aus der G2-Phase in die M-Phase auslöst. Die Prophase der Meiose I gleicht der G2-Phase einer mitotischen Zellteilung, denn die DNA hat sich repliziert und wird transkribiert, die Kernhülle ist intakt und der mitotische Spindelapparat noch nicht ausgebildet.

Arbeiten an Hefepilzen sowie an Seeigel- und Froschoozyten zeigen, daß das Fortschreiten des Zellzyklus von der G2- zur M-Phase hauptsächlich auf Aktivitätsveränderungen des p34-Proteins, einem Produkt des cdc2-Gens (cell division cycle), in Kombination mit weiteren Eiweißstoffen zurückzuführen ist. So wird über cAMP eine Proteinkinase A aktiviert, die für eine Phosphorilierung des Proteins p34 verantwortlich gemacht wird. Durch die Bindung von Cyclin B an p34 wird ein aktiver MPF-Komplex gebildet. Allerdings ist stark phosphoriliertes p34 nicht in der Lage, Cyclin zu binden, so daß es erst nach einer Senkung des cAMP-Spiegels zur Bildung von aktivem MPF kommt, der für den Fortgang der Meiose verantwortlich ist. Der MPF ist somit eine Kinase, die eine Kaskade von Phosphorylierungen initiiert (HERRLER \& BEIER, 1998).

SZÖLLÖSI (1993) beschreibt den MPF als einen Faktor, der aus zwei Komponenten besteht:

1. Eine katalytische Untereinheit aus einem $34 \mathrm{kD}$ Protein, welches das Produkt des Hefe - Gens $\mathrm{cdc}_{2} / \mathrm{cdc}_{28}$ (cdc=cell division control) ist (LABBE et al., 1989).

2. Eine regulatorische Untereinheit aus einem $45 \mathrm{kD}$ Protein, welches Cyklin B genannt wird und ein homologes Produkt des Hefegens cdc 13 darstellt.

Das reife Zytoplasma der Oozyte muß eine Anordnung der kortikalen Granulae in der Peripherie der Oozyte vollzogen haben (CRAN \& CHENG, 1985; 1986). Der Interspezies Vergleich bezüglich der Anzahl der kortikalen Granulae zeigt, daß das Schwein wesentlich mehr Granulae besitzt als Maus, Ratte und Kaninchen (CRAN \& CHENG, 1985). Die Granulae tragen zur Bildung des Polyspermieblocks bei, indem sie nach Fusion einer Spermatozoe mit der Oozyte das Eindringen weiterer Spermatozoen verhindern helfen. 
Weiterhin muß das reife Oozytenzytoplasma einen Faktor synthetisieren, der für die Dekondensation des eingedrungenen Spermienkopfes sorgt. Hierbei handelt es sich um den sogenannten Male-Pronucleus-Growth-Faktor (MPGF) (MOOR, et al., 1983).

Nach Erreichen der Metaphase I wird ein Polkörper in den perivitellinen Raum der Oozyte ausgeschleust und die Eizelle wird in der Metaphase II durch den cytostatischen Faktor (CSF) abermals arretiert. Nur eine eingedrungene Spermatozoe ist in der Lage, die Arretierung aufzuheben und die Meiose der Oozyte vollenden zu lassen. Findet diese Spermienpenetration nicht statt, stirbt die Oozyte -je nach Spezies- mehr oder weniger schnell ab.

Erste grundlegende Erkenntnisse zu den Befruchtungsvorgängen wurden von GURDON 1968 und 1973 extrakorporal an Xenopus laevis erforscht.

\subsubsection{Inhibin als lokaler Regulator der Follikulogenese}

Ein Faktor, der für die Hemmung der Follikel-und Oozytenentwicklung verantwortlich gemacht wird, ist das Inhibin.

Durch Inhibin wird die Freisetztung von Follikelstimulierendem Hormon (FSH) aus dem Hypophysenvorderlappen gehemmt. Die Bioaktivität von Inhibin in Form einer Unterdrückung der FSH-Produktion durch die hpophysären Zellen wurde zuerst von De JONG \& SHARP (1976) beschrieben. Inhibin wird von den Granulosazellen synthetisiert und sezerniert und akkumuliert sich in der Follikelflüssigkeit (BICSAK et al., 1986; MOORE et al., 1994). Duch die Isolierung und Aufreinigung von Inhibin aus Follikelflüssigkeit wurde festgestellt, daß Inhibin zu Mitgliedern der Transforming Growth Factor- $\beta$-Familie gehört, die auf extragonadales Gewebe eine parakrine und autokrine Wirkung ausübt (MASON et al., 1985; FINDLAY, 1993; FINDLAY et al. 1993).

Es konnte weiterhin gezeigt werden, daß Inhibin in vivo signifikante Veränderungen der FSH Werte mit einhergehenden Änderungen der Follikulogenese induziert.

So vermindert Inhibin den post-ovulatorischen FSH-Anstieg bei der Ratte und unterdrückt die Rekrutierung der Follikel für den nächsten Zyklus. Beim weiblichen Rhesusaffen verhindert eine Injektion mit Follikelflüssigkeit $\mathrm{zu}$ Beginn der Follikelphase eine Follikelrekrutierung gefolgt von einer unzureichenden Lutealphase. In vitro zeigen die Lutealzellen dieser behandelten Tiere eine verminderte hCGSensibilität (STOUFFER \& HODGEN, 1980). Inhibin-immunisierte Schafe und Rinder zeigen eine zahlenmäßig gesteigerte Ovulationsrate und Follikelentwicklung, indem die Wirkung von Inhibin durch Antikörper neutralisiert wird (HENDERSON et al., 
1984; GLENCROSS et al., 1994; O’SHEA et al., 1994). Neuere Arbeiten von DIETRICH et al., 1993 und 1995 an der Ziege belegen, daß durch eine Immunisierung der Tiere mit einer humanen Inhibin $\alpha$-Untereinheit die Zahl der Follikel drastisch erhöht werden konnte. Weiterhin konnten dreimal soviele Embryonen von immunisierten Ziegen durch die unblutige Spülung des Uterus gefunden werden als bei Kontrolltieren ohne Immunisierung.

Im In-vivo-Modell wurde bewiesen, daß das Glykoproteinhormon Inhibin einen negativen Feedback auf die Sekretion von FSH bewirkt (MOORE et al., 1994).

Der quantitative Inhibingehalt ist von der Follikelgröße und dem Follikelstatus abhängig. In der Follikelflüssigkeit atretischer Follikel sind geringere Mengen an bioaktivem Inhibin vorhanden (SCOTT et al., 1980), während der Inhibingehalt in großen Follikeln erhöht ist (ROTTEN, 1993).

Durch Inhibin kann der Follikel direkt mit der Hypophyse in einer Feedback Beziehung kommunizieren, so daß auf diese Weise über FSH bestimmt werden kann, wieviele der wachsenden Follikel auch zur Ovulation kommen dürfen (FINDLAY et al., 1992; FINDLAY, 1994).

Auch in vitro ist Inhibin in der Lage, FSH-Konzentrationen und somit deren maturationsfördernde Wirkung negativ zu beeinflussen (FINDLAY et al., 1993). Die In-vitro-Maturation bei Rattenoozyten wurde durch den Zusatz von Inhibin unterdrückt (O et al., 1989).

\subsection{Maturation in vitro}

Die oben angesprochene meiotische Kompetenz wird in vivo während der Entwicklungsperiode der Antrumformation erreicht (MOTLIK et al., 1984). Hat der Follikel in der Mitte des Zyklus eine spezies-spezifische Größe erreicht, nimmt die Oozyte nach Freisetzung aus dem Follikel spontan die Meiose wieder auf (PINCUS \& ENZMANN, 1935, CHANG, 1955 a,b; EDWARDS, 1965). SZÖLLÖSI (1993) gibt an, daß die Oozyten von Hausschwein, Schaf, Ziege und Kuh ihre meiotische Maturation wieder aufnehmen, wenn ihre Follikel eine Größe von 3mm im Durchmesser erreicht haben. Dagegen können menschliche Oozyten erst reifen, wenn die Follikel zu einer Größe von mindestens $15 \mathrm{~mm}$ herangewachsen sind.

Im Rahmen der Tierzucht und Humanmedizin besteht großes Interesse, Oozyten in vitro zu reifen. Aber nur mit einer physiologisch ablaufenden In-vitro-Maturation wird die Grundlage für ein weiteres embryonales Wachstum geschaffen. 
CANIPARI et al. stellten 1984 fest, daß Mäuseoozyten im Follikel nach einer 2-10 tägigen Kultur auf Fibroblasten-Monolayer ebenfalls die Meiose wieder aufnehmen. Aus dieser Studie wurde deutlich, daß das Erreichen der meiotischen Kompetenz zwar von einem gentischen Programm der Oozyte abhängt, das aber durch das Follikelwachstum initiiert wird. In-vitro-Kulturen intakter Follikel haben gezeigt, daß bis zur Ovulationsinduktion durch LH die Präsenz der Granulosazellen für die meiotische Arretierung verantwortlich ist. Diese Zellen synthetisieren den „oocyte meiosis inhibitor“(OMI), ein Polypeptid mit einem Molekulargewicht von ca. 2000 Da, der für den meiotischen Block verantwortlich ist (MATTIOLI et al., 1994).

Wie in Kapitel 2.1.1.2. ausführlich beschrieben wurde, sind Follikelzellen in der Lage, Oozyten in Primordialfollikeln über Jahre zu arretieren und das Wachstum zu blockieren (THIBAULT et al., 1987). Die Follikelzellen sind somit Regulatoren der ovariellen Funktionen (DING \& FOXCROFT, 1992).

Für die Wiederaufnahme der Meiose in der Oozyte spielt der intrazelluläre cAMP (cyclisches Adenosin-Monophosphat)-Gehalt eine dominante Rolle, der sowohl durch OMI als auch anderen Faktoren beeinflußt wird. Die Arretierung der Meiose erfolgt durch hohe cAMP Gehalte (SCHULTZ, 1987; MATTIOLI et al., 1994). Beweis dafür, daß cAMP und Follikelzellen in engem Zusammenhang stehen, sind die Ergebnisse von RACOWSKY (1985). Sie setzte die Chemikalie Forskolin als Stimulator der Adenylatcyclase zur Erhöhung der cAMP-Gehalte und somit zu einer Hemmung der Kernreife ein. In kumulusfreien Oozyten blieb die gewünschte Wirkung aus. Eine Purinbase, Adenosin, und eine Purinnucleotid, Hypoxanthin, sind in vitro auch potentielle Inhibitoren von cAMP Phosphodiesterase. Sie sind in der Follikelflüssigkeit als niedermolekulare Substanzen entdeckt worden und fungieren als Inhibitoren der meiotischen Maturation, wenn Kumulus-Oozyten-Komplexe isoliert und kultiviert werden (EPPIG \& DOWNS, 1988).

LARSEN et al. (1986) erkannten, daß die Innigkeit der Verbindung des KumulusOozyten-Komplexes durch Hyaluronsäureeinlagerungen mit voranschreitender Maturation immer lockerer wird. Konsequenz der sich lösenden Zellverbände ist, daß die Kommunikation der eizellumgebenden Zellen und der Oozyte selbst unterbrochen wird.

EPPIG (1979b) stellt fest, daß im Maturationsmedium unbedingt eine Serumkomponente mit einem hohen Molekulargewicht von mehr als 10000 vorhanden sein muß, um diese Kumulusexpansion durch Hyaluronsäureeinlagerungen zu induzieren. Serum im Maturationsmedium verhindert eine spontane Härtung der 
Zona pellucida. Oozyten im Medium ohne Serum sind nicht penetrationsfähig (EPPIG \& SCHROEDER, 1986).

Hormone spielen in vivo die fundamentale Rolle bei der Erlangung der meiotischen Kompetenz der Oozyten. Auch bei der Reifung in vitro ist der Erfolg einer synchronen nuklearen und zytoplasmatischen Reifung unter anderem von zugesetzten Hormonen abhängig (OSBORN \& MOOR, 1983). Das steroide Muster im Medium bei der In-vitroMaturation soll dem der Follikelflüssigkeit aus präovulatorischen Follikeln entsprechen: Die Östrogenspiegel müssen hoch, die Progesteronspiegel niedrig sein (STAIGMILLER \& MOOR, 1984). Hormonzusätze sind im Maturationsmedium für porcine Oozyten notwendig, um eine nukleare Maturation und Kumulusexpansion der Kumulus-Oozyten Komlpexe zu erzielen (MEINECKE \& MEINECKE-TILLMANN 1979;HILLENSJO \& CHANNING, 1980; YOSHIDA et al, 1989). Die Anwesenheit der Kumuluszellen wiederum spielt eine entscheidene Rolle für die Befruchtungsfähigkeit der Oozyten. Nur kumulusumhüllte Oozyten zeigen gute Fertilisationsraten und die Ausbildung von Vorkernen (KIKUCHI et al., 1991; 1993).

Bei der spontanen Aufnahme der Meiose in vitro findet zwar eine nukleare Reifung der Oozyten statt, allerdings scheint die zytoplasmatische Reifung auszubleiben (EPPIG \& SCHROEDER, 1986; MATTIOLI et al., 1988b).

\subsection{Mechanismen, die den meiotischen Block der Oozyten beenden}

Wenn die Oozyte ihre spezies-spezifische Größe zur Initiierung der Weiterentwicklung erreicht hat, ist eine hormonelle Stimulation für die anstehenden morphologischen und metabolischen Veränderungen verantwortlich. Durch diese Stimulation findet eine Unterbrechung der Gap junctions zwischen Oozyte und Corona radiata statt. Die Meiose-Inhibitoren (Oocyte Maturation Inhibitor = OMI, Adenosin), die bisher über die Corona radiata auf die Oozyte einwirken konnten, werden dadurch ausgeschaltet (SZÖLLÖSI, 1993). Der Zusammenbruch der interzellullären Verbindungen über die Gap Junctions induziert sehr schnell die Auflösung der Kernmenmbran des germinalen Vesikulums. Durch das Verschwinden der meiotischen Inhibitoren erfolgt eine Erniedrigung der cAMP-Gehalte in der Oozyte und die Wiederaufnahme der Meiose.

Nach Erreichen der Metaphse II und einem physiologisch gereiften Zytoplasma hat die Oozyte ausreichend Male Pronucleus Growth Faktor (MPGF) akkumuliert, der sie befähigt, einen eingedrungenen Spermienkopf zu dekondensieren und den männlichen Vorkern auszubilden (DING et al., 1992a). Bei der IVF erleichtert die Anwesenheit von 
Kumuluszellen die Spermienpenetration und somit die männliche Vorkernbildung (BALL et al., 1983; KIKUCHI et al., 1993). BÖTTCHER et al. (1990) schreiben den Kumuluszellen vielfältige Funktionen zu. So fungieren sie als Mediatoren wachstumstumsfördernder Substanzen und bestimmter Strukturproteine. Sie sezerniern sowohl reifungshemmende als auch reifungsfördernde Faktoren und haben Ernährungs- und Schutzfunktionen für die Oozyten.

\subsection{Gewinnung und Selektion der Kumulus-Oozyten-Komplexe}

Ausgangsmaterial für die Gewinnung der Oozyten waren Ovarien geschlachteter peripuberaler Jungsauen. Die pathologisch unveränderten Eierstöcke befanden sich in der Follikelphase ohne Gelbkörper.

NAGAI et al. (1983) sehen einen engen Zusammenhang zwischen der Maturationsrate porciner Oozyten und der Umgebungstemperatur während der Ovariensammlung am Schlachthof. So erhielten die Autoren im Winterhalbjahr, wenn die Oozyten unter $20^{\circ} \mathrm{C}$ abkühlten, schlechte Reifungsergebnisse. PRATHER et al. (1991) bestätigen diese Aussage, indem sie die Vorkernbildung von Oozyten beobachten, die entweder bei $29^{\circ}$ oder $36^{\circ} \mathrm{C}$ transportiert worden waren. Bei höheren Temperaturen konnten sie signifikant bessere Befruchtungsraten feststellen.

Im Gegensatz dazu stehen Untersuchungen von ROSENKRANS (1993), in denen lediglich die nukleare Reifungsrate nach In-vitro-Maturation bestimmt wurde. Die besten Maturationsraten wurden nach einem Ovartransport in nur $20^{\circ} \mathrm{C}$ warmem Transportmedium erzielt.

Zur Eizellgewinnung bieten sich zwei unterschiedliche Methoden an. HAMANO \& KUWAYAMA (1993) vergleichen die Follikelaspiration der Oozyten mit dem Schneiden der Follikel. Die Ergebnisse zeigen, daß sowohl Qualität als auch Quantität der Oozyten mit der Schneidemethode erhöht werden können. Da beim Schneiden der Follikel keine physikalischen Kräfte auf die Oozyten durch Sog oder Ähnliches ausgeübt werden, wird bei diesen Oozyten der Kumulus oophorus bei der Gewinnung nicht in Mitleidenschaft gezogen und bleibt weitgehend intakt. 


\subsection{Spermatozoenreifung}

\subsubsection{Kapazitation mit anschließender Akrosomenreaktion}

Nach Vollendung der Passage durch den Ductus epididymidis hat eine epididymale Reifung der Spermatozoen stattgefunden (YANAGIMACHI, 1988). Mit dieser Reifung erlangen die Spermien die Fähigkeit, sich zu bewegen.

Schon sehr früh haben der chinesisch-amerikanische Reproduktionsbiologe M.C. CHANG (1951, 1969) und der australische Physiologe C.R. AUSTIN (1951, 1960) erkannt, daß eine vollständige Befruchtungsfähigkeit erlangt werden kann, indem ein abschließender Maturationsprozeß der Spermien innerhalb des weiblichen Genitaltraktes stattfindet, der als Kapazitation bezeichnet wird (SALING, 1989).

Die Kapazitation der Spermatozoen beinhaltet eine strukturelle und biochemische Veränderung der Plasmamembran sowie der äußeren akrosomalen Membran. Cholesterin Konzentrationen der Spermatozoen werden erniedrigt (DAVIS, 1981) und Proteine oder Kohlenhydrate gehen den Plasmamembranen verloren (POIRIER \& JACKSON, 1981; LOPEZ et al., 1985; WILSON \& OLIPHANT, 1987;). Die Schlüsselereignisse der Kapazitation sind der Efflux von Cholesterin und der Influx von Kalziumionen (TÖPFER-PETERSEN et al., 1996). Ziel ist es auch in vitro diese Oberflächenantigene (Cholesterin-Konzentrationen, Proteine und Kohlenhydrate), sog. Surface-coat-Moleküle von der Spermienzellmembran zu entfernen Diese Entfernung soll eine extreme Membrandepolarisation zur Folge haben (AUSTIN, 1975; OLSON \& HAMILTON, 1978; WILLIAMS, 1972, YANAGIMACHI et al., 1973).

Es kommt zu einer Änderung der Lipid- und Glykoproteinzusammensetzung der Spermaplasmamembran, einer Steigerung der Stoffwechselrate mit einhergehender Erhöhung der Motilität der Spermien zu einer sogenannten Hypermotilität (FIRST \& PARRISH, 1987; PARRISH et al., 1988; YANAGIMACHI, 1988; 1989). Kapazitierte Spermatozoen weisen also eine Aktivitätssteigerung auf, mit der sie schneller, kräftiger und zielstrebiger werden (BEIER, 1992). Die Penetration des KumulusZellverbandes und der Zona pellucida muß zu einem beträchtlichen Anteil diesen mechanischen Aktivitäten zugeschrieben werden (BEDFORD, 1983).

HUNTER \& HALL (1974) konnten zeigen, daß der Eileiter bezüglich der Kapazitation von Eberspermien eine wesentliche Rolle spielt. Aufgrund des hormon-abhängigen Kapazitationsverlaufes fördert das östrogendominante Milieu der Follikel und Eileiter die Kapazitation. 
Nur wenn die Kapazitation abgelaufen ist, kann es zum endgültigen Reifungsschritt der Spermatozoen kommen, der Akrosomenreaktion. Es handelt sich hierbei um Veränderungen der Membranverhältnisse im vorderen, akrosomalen Bereich der Spermatozoen, der sie dazu befähigt, die Zona pellucida und Eizellmembran zu penetrieren. Das Akrosom, welches unter anderem das für die Fertilisation wichtige Enzym Hyaluronsäure und die Protease Akrosin enthält, ist als Organell des Spermienkopfes während der Spermatogenese aus dem Golgi-Apparat der Spermatide entstanden (BEIER, 1992). Das mit Enzymen gefüllte, membranumschlossene Organell sitzt wie eine Kappe auf dem vorderen Teil der reifen Spermatozoe. Bei abgeschlossener Kapazitazitation haben sich zwischen Plasmalemm der Spermatozoen und äußerer Akrosomenmembran Ionenkanäle gebildet.

Die Akrosomenreaktion ist ein kationen-abhängiger Prozeß. Calcium- und KaliumIonen spielen hierbei eine Schlüsselrolle. Hohe Konzentrationen an Kalium steigern die Fähigkeit der Spermatozoen, die Oozyten zu penetrieren. Ferner werden die intrazellulären Konzentrationen an freien $\mathrm{Ca}^{2+}$-Ionen in den Spermatozoen erhöht, was zur Akrosomenreaktion führt (SUZUKI et al., 1994a). Calciumstabilisatoren wie Caseinphosphopeptide können diesen Effekt weiter unterstützen (ABE et al., 1994; MORI et al., 1994). Der entscheidene Schritt der Akrosomenreaktion ist die partielle Auflösung und die Membranfusion der äußeren Akrosomenmembran mit dem Plasmalemm. Hierbei entstehen als Übergangsstadium bis zur völligen Ablösung größerer Akrosomenteile vesikuläre Membranstrukturen, zwischen denen sich Öffnungen bilden, durch die der Inhalt des Akrosoms in die nächste Umgebung fließen kann. Dabei handelt es sich um lytische Enzyme wie z. B. Akrosin und andere Proteasen, Hyaluronidase, $\beta$-Glukuronidase und N-Acety-Glukosaminidase.

\subsubsection{In-vitro- Kapazitation beim Schwein}

Zur Simulation der In-vivo-Bedingungen inkubierte RATH (1992) Eberspermatozoen im porcinen östrischen isolierten und ligierten Uterus. Überraschenderweise waren die nachfolgenden In-vitro-Befruchtungsraten schlechter als nach einer Inkubation der Spermatozoen in TCM199. Außerdem wurde eine erhöhte Inzidenz von sogenannten Head-to-Head-Aggregationen der Spermatozoen beobachtet, die im ligierten Uterus kapazitiert wurden. Es handelt sich hierbei um eine Aggregation von Spermatozoen, die sich mit den Köpfen gegenseitig verbinden. Sie soll durch eine überstürzte Akrosomenreaktion forciert werden und limitiert somit die Befruchtungsraten (HAMANO et al., 1989). Ferner wurden im ligierten Uterus erhöhte Kontaminationen 
beobachtet, so daß diese Form der physiologischen Simulation einer Kapazitation keine Verbesserungen für das In-vitro-System bringt.

Eine hohe Inkubationsdichte der Spermien während der In-vitro-Kapazitation zeigte in den Untersuchungen von NAGAI et al. (1984) gute nachfolgende Penetrationsraten der Oozyten. Die Autoren führen dies auf eine Akkumulation von Taurin und Hypotaurin aus den Eberspermatozoen (VAN der HORST \& GROOTEN, 1966) zurück. HAMANO et al. (1989) konnten diese Ergebnisse nicht bestätigen. Sie beobachteten, daß Substanzen, die Eberspermatozoen stimulieren, durch lebende Spermien während der Inkubation im Kapazitationsmedium akkumuliert werden, hitzestabil sind und ein niedriges Molekulargewicht haben. Ohne diese Substanzen zu benennen zu können, wurden aber Taurin oder Hypotaurin ausgeschlossen.

\subsection{Reifung, Befruchtung und Kultur porciner Oozyten in vitro}

Die ersten Maturationsversuche mit porcinen Oozyten wurden von EDWARDS (1965) durchgeführt. Es wurde deutlich, daß die Oozytenreifung ein Schlüsselereignis für die nachfolgende In-vitro-Fertilisation darstellt.

Nach Entnahme aus dem Follikel nehmen die Oozyten des Schweines innerhalb der folgenden 20-24 Stunden in geeigneten Kulturmedien die Meiose wieder auf, was durch den Germinal vesicle breakdown (GVBD) gekennzeichnet ist. Voraussetzung ist, daß eine aktive Proteinbiosynthese zur Erhaltung der Oozyte besteht (MOOR \& CROSBY, 1986; HUNTER \& MOOR, 1987), die wiederum nur durch Etablierung physiologischer Kultivierungssysteme zur Erhaltung der Vitalität der Oozyten gegeben ist.

Die üblicherweise benutzen Basis-Kulturmedien zur Oozytenreifung sind TCM199 (NAGAI et al., 1988; MATTIOLI et al., 1989; YOSHIDA et al., 1989; YOSHIDA et al., 1990; WANG et al., 1991; WANG et al., 1992), modifizierte Krebs-Ringer Bikarbonatlösung (SATO et al., 1978; IRITANI et al., 1978; NAGAI et al., 1984) und modifiziertes Waymouth`s MB752/1-Medium (KIKUCHI et al., 1995). Die Arbeitgruppe von ABEYDEERA et al. $(1997,1998)$ benutzen das North Carolina State University 23 (NCSU 23) bereits als Maturationsmedium, welches erstmals von PETTERS und REED (1993) zur Kultur von porcinen Embryonen propagiert wurde.

Die Osmolarität des Reifungsmediums sollte nicht mehr als $305 \mathrm{mOsm} / \mathrm{kg}$ aufweisen (McGAUGHEY, 1975; 1977; FUNAHASHI et al., 1994b)

Als Proteinzuusätze zu diesen Medien wurden Fetales Kälberserum (FKS) (MINATO \& TOYODA, 1982), porcine Follikelflüssigkeit (pFF), porcine Amnionflüssigkeit (NAGAI et al., 1990), bovines Serumalbumin (BSA) (McGAUGHEY, 1977) sowie 
Schweinekastratenserum (TSAFRIRI \& CHANNING, 1975; ENG et al., 1986) verwendet. Zusätzlich ist eine gleichzeitige Supplementierung von Gonadotropinen notwendig, um die meiotische Reifung zu initiieren (MEINECKE \& MEINECKETILLMANN; 1979; YOSHIDA et al., 1989; NAGAI et al., 1990; FUNAHASHI \& DAY, 1993) und, um die von vielen Arbeitsgruppen beschriebenen OozytenMaturationshemmer zu neutralisieren. Eine Entfernung der hormonellen Zusätze zum Zeitpunkt des Germinal vesicle breakdowns (20-22 h nach Kulturbeginn) soll die Fähigkeit der Oozyten einen männlichen Vorkern nach der Befruchtung auszubilden verbessern (FUNASHASHI \& DAY, 1993, FUNAHASHI et al. 1994c). Angaben zu Reifungszeiten der In-vitro-Maturation variieren stark zwischen den Arbeitsgruppen (36 h = WANG et al., 1994; $39 \mathrm{~h}=$ OCAMPO et al., 1994; $44 \mathrm{~h}=$ MATTIOLI et al., 1988a, 46 h, MATTIOLI et al., 1988b; KIKUCHI et al., 1991; 48 h = PRATHER et al., 1991). Vergleichende Studien von MINATO \& TOYODA (1982) haben gezeigt, daß die In-vivo-Reifungzeiten von $48 \mathrm{~h}$ mit den In-vitro-Zeiten bei optimalen Kultivierungsbedingungen übereinstimmen sollten. Somit unterscheidet sich das Schwein extrem von anderen Spezies, deren Oozyten wesentlich kürzer für die Invitro-Reifung inkubiert werden müssen (McGAUGHEY et al., 1977; MATTIOLI, 1994). In-vivo-Studien haben gezeigt, daß $12 \mathrm{~h}$ nach einer Behandlung mit humanem Chorion Gonadotropin (hCG), wenn Nagetiere bereits ovulieren, beim Schwein noch immer ein Germinales vesiclulum mit ersten Hinweisen auf eine Chromatin-Dekondensierung besteht (MOTLIK \& FULKA, 1976). 24 h nach hCG-Injektion, wenn die Oozyten von Schaf und Rind schon ihre Reifung vollendet haben, erreichen die Oozyten des Schweines erst die Prometaphase oder Metaphase I (HUNTER \& POLGE, 1966). Das bedeutet, daß der Nukleus von Schweineoozyten dreimal solange wie der von Nagetieren und doppelt so lange wie der von Schaf oder Rind zum Reifen benötigt (MATTIOLI et al., 1988b).

Die Reifungszeit scheint einen wichtigen Einfluß auf die kortikale Reaktion zu haben. In-vivo-Studien von HANCOCK (1959) und HUNTER (1967) haben gezeigt, daß eine Befruchtung mit kapazitierten Spermien nach sowohl 30 als auch nach 50 Stunden nach hCG in hohen Polyspermieraten beim Schwein resultiert. Im ersten Fall (30 Stunden post hCG) hat die kortikale Reaktion noch nicht stattgefunden im zweiten (50 Stunden post hCG) sind die entlassenen kortikalen Granulae zu alt und werden von CRAN \& CHENG (1985) als sehr dunkel und somit überreift beschrieben.

Die Arbeitsgruppen von NAGAI et al. (1984) und MATTIOLI et al. (1988a), können beide gute Ergebnisse bezüglich der Vorkernbildung beobachteten, obwohl sie mit langen von 44 Stunden (MATTIOLI et al.1988a) bzw. kurzen von 28-29 Stunden 
(NAGAI et al.1984) Maturationszeiten der Schweineoozyten arbeiteten. Als Begründung wurde von MATTIOLI et al. (1988a) angegeben, daß es zwischen dem verwendeten Tiermaterial beider Arbeitsgruppen genetische Unterschiede gibt, die eine unterschiedliche Reifungszeit der Oozyten mit sich bringen.

Weiterhin wurde versucht, unreife, kumulusfreie Oozyten im GV-Stadium zu befruchten (PERRAULT et al., 1988; YOSHIDA, 1993; GRUPEN et al., 1995). Es wurde eine Spermadekondensierung beobachtet, woraus geschlossen werden konnte, daß die dekondensierenden Faktoren, wie z. B. reduzierte Glutathion-Gehalte im Zytoplasma der Oozyten vorhanden sind. Dagegen ist es porcinen Spermatozoen nicht möglich, unreife, aber kumulusintakte Oozyten zu penetrieren (FUNAHASHI \& DAY, 1993). Eine expandierte Kumulusmasse hingegen verbessert sowohl die Spermamotilität als auch die Oozytenqualität. Der expandierte Kumulus unterstützt in vitro die Spermakapazitation und Akrosomenreaktion (COX, 1991), wenn zusätzlich noch Coffein im Fertilisationsmedium enthalten ist.

Befruchtungsmedien ohne Coffein führen nur zu geringen Sperma-Penetrationsraten (WANG et al., 1991; SUZUKI et al., 1994b). Coffein erhöht die für die Kapazitation notwendigen intrazellulären Calciuminonen in den Spermatozoen (MORI et al., 1993; TÖPFER-PETERSEN et al., 1996). Sind Coffein (GARBERS et al., 1973; BAMBA \& KOJIMA, 1978; FRASER, 1979) und Bicarbonat (TAJIMA et al., 1987) zugleich im Fertilisationsmedium dann treten synergistische Effekte auf. Die Motilität von Eberspermatozoen wurde erhöht und die Plasmamembran der Spermatozoen wurde in Vorbereitung auf die Fusionsprozesse mit der Oozyte destabilisiert (HARRISON et al., 1993). SUZUKI et al. (1994b) schreiben vor allem Bicarbonat im Fertilisationssystem beim Schwein den positiven Effekt zu.

Über die Inkubationstemperaturen von Schweineoozyten herrschen in der Literatur unterschiedliche Meinungen. Während ENG et al. (1986) eine bessere Polkörperformation beobachten, wenn die Oozyten bei $39^{\circ} \mathrm{C}$ statt bei $37^{\circ} \mathrm{C}$ kultiviert wurden, zeigten BETANCOURT et al. (1993), daß eine Inkubation der zu reifenden Oozyten bei $37^{\circ} \mathrm{C}$ zu keinerlei Polyspermie bei hoher Befruchtungsrate führte. ENG et al. (1986) fanden heraus, daß eine Inkubation in einem $\mathrm{CO}_{2}$-begasten bicarbonatgepufferten Medium die Grundlage einer problemlosen In-vitro-Maturation beim Schwein darstellt.

Neben der nuklearen muß auch eine zytoplasmatische Reifung in vitro erzielt werden. Die Überprüfung des erfolgreichen Ablaufes dieser Form der Reifung gestaltet sich als schwierig, so daß zumeist die männliche Vorkernbildung als Indiz dafür benutzt wird. DING \& FOXCROFT (1994) beschreiben, daß eine Reifung porciner Oozyten in 
follikelzell-konditionierten Medien gute Erfolge bezüglich der Vorkernbildung und somit einer zytoplasmatischen Reifung liefert. Ähnliche Ergebnisse von DING et al. (1992b), MATTIOLI et al., (1988a, b), ZHENG \& SIRARD (1992), NAGAI et al., (1993) ABEYDEERA (1998) bestätigen diese Ergebnisse. DING \& FOXCROFT (1994) betonen allerdings, daß nur FSH ohne LH im konditionierten Medium diese guten Ergebnisse liefert, während MATTIOLI et al. (1988a) beide Hormone einsetzen.

Neben der nuklearen und zytoplasmatischen Reifung in vitro ist die Kumulusreifung mit einhergehender Expansion eine weitere Voraussetzung der In-vitro-Maturation. Die Zellen des Kumulus oophorus werden als Ergebnis von HyaluronsäureEinlagerungen unter anderem durch die Stimulation durch FSH getrennt und die zellverbindende Substanz durch Schleim ersetzt (EPPIG, 1979a). Auch ein in vivo ovuliertes Säugerei besitzt diese muzifizierten Kumulusmassen (EPPIG, 1980). Wahrscheinlich spielt diese Muzifizierung für die Passage der ovulierten Oozyte durch den Eileiter eine wichtige Rolle (SZÖLLÖSI, 1993). Die Expansion des Kumulus oophorus wird von vielen Autoren als ein Hinweis auf sowohl nukleare als auch zytoplasmatische Reifung angesehen (GILULA et al., 1978; LEIBFRIED \& FIRST, 1979; EPPIG, 1980; SÜSS et al, 1988; WERT \& LARSEN, 1988; CHEN et al.,1990). YOSHIDA et al. (1992) halten diese Korrelation für sehr unwahrscheinlich, da man nach der In-vitro-Maturation hohe Raten an expandierten Oozyten, ohne Manifestation der Metaphase II beobachten kann.

Es wurde beobachtet, daß die Kumulusexpansion in vitro schneller stattfindet als in vivo, womit die schlechten Entwicklungsraten bei der In-vitro-Befruchtung im porcinen System erklärt werden könnten. Das lange Beibehalten der intrazellulären Verbände während der Maturation scheint also beim Schwein eine sehr wichtige Rolle zu spielen, um einer überstürzten Reifung vorzubeugen (MOTLIK et al., 1986; MATTIOLI et al., 1988b). SZÖLLÖSI (1980) vermutet, daß sobald die Gap junctions zwischen der Oozyte und der Corona radiata verschwinden, eine gleichzeitige Entlassung der Kortikalen Granulae einhergeht, so daß die unreife Oozyte durch Veränderungen der Zona verfrüht nicht mehr penetrierbar ist. Dieser Vermutung steht allerdings die hohe Rate an Polyspermie bei der porcinen In-vitro-Fertilisation entgegen.

Der Epidermal growth factor (EGF) ist ein potentieller Stimulator der Kumulusexpansion (DOWNS et al., 1988). VANDERHYDEN (1993) stellte fest, daß die Oozyten von Maus und Ratte als Antwort auf EGF einen Faktor sezernieren, der den Kumulus zur Expansion befähigt. Die Oozyte des Schweines sezerniert ebenfalls diesen Faktor, allerdings ist die Kumulusexpanision dieser Spezies von ihm 
unabhänig, so daß geschlossen werden kann, daß die Regulation der Kumulusexpansion beim Schwein unterschiedlich zu der von Nagetieren ist.

Bei der In-vitro-Fertilisation von Schweineoozyten resultiert die hohe Polyspermierate unter anderem aus der fehlenden kortikalen Reaktion. Unzulänglichkeiten in der Invitro-Maturation scheinen hierfür der Grund zu sein. CRAN \& CHENG (1986) schlagen deshalb eine Supplementierung von Calciumionophore zum Medium vor, da die Dispersion der kortikalen Granulae vom intracellullären Calciumgehalt abhängt. Die Senkung der Polyspermierate kann auch durch eine Insemination mit einer Spermiendichte von 2 x $10^{3}$ erreicht werden (RATH, 1992). Auch porcine Follikelflüssigkeit soll während der Maturation einen entscheidenen Effekt auf die Senkung der Polyspermierate haben (FUNAHASHI et al., 1994a)

Die Untersuchungen von OCAMPO et al. (1994) und KIKUCHI et al. (1995) zeigen, daß porcine Spermatozoen in vitro bereits 3 Stunden nach Zugabe zum Medium die Oozyte erreichen und kurz darauf in das Ooplasma eindringen. Durch die Fusion mit der Zona pellucida wird die Arretierung aus der Metaphase II aufgehoben. 6-9 Stunden danach findet die Ausschleusung des zweiten Polkörpers und 12-18 Stunden später die männliche und weibliche Vorkernbildung statt, während DING et al. (1992a) bereits schon nach 8 Stunden den männlichen und weiblichen Vorkern identifizieren können. 24 Stunden später kann die Verschmelzung (Syngamie) der Vorkerne beobachtet werden.

In der Embryonalentwicklung in vitro zeigen Schweineembryonen einen sogenannten Zellblock; daß heißt, sie entwickeln sich nur sehr schlecht über das 2-4 Zellstadium hinaus (DAVIS, 1985; REED et al., 1992; PETTERS, 1992). Außerdem erstreckt sich die Phase des 4-Zell-Stadiums beim Schwein über einen großen Zeitraum (POLGE, 1982). Der Grund ist eine unzureichende Aktivierung des embryonalen Genoms in diesem Zellteilungsstadium, indem die Steuerung der Proteinsynthese vom maternalen auf das fetale Genom umgeschaltet wird (GANDOLFI \& MOOR, 1987, BARNES \& EYESTONE, 1990). Schweineembryonen zeigen nach In-vitro-Fertilisation nur eine geringe Fähigkeit zu einer weiteren Entwicklung (TORRES \& RATH, 1992). Eine Möglichkeit, die In-vitro-Zellblock-Barriere $\mathrm{zu}$ überwinden ist, die in vitro erzeugten Embryonen in situ in einen Eileiter zurückzutransferieren (WHITTINGHAM \& BIGGERS, 1968). Weiterhin kann eine Embryokultur auf Feederlayern, die aus Eileiterzellen bestehen, über diesen Entwicklungsblock hinweghelfen (WHITTINGHAM \& BIGGERS, 1968). Daraus kann geschlossen werden, daß die Zusammensetzung herkömmlicher Kulturmedien nicht optimal ist (GANDOLFI \& MOOR, 1987). 
TROUNSON et al. (1994) empfehlen einen regelmäßigen Mediumwechsel, um einer Ammoniumtoxität innerhalb des Mediums vorzubeugen. Weiterhin schlagen die Autoren vor, immer eine größere Anzahl von Embryonen zusammen zu kultivieren, um so den auto- und paracrinen Effekt zu nutzen.

\subsection{Anforderungen und Möglichkeiten der frühen Embryokultur}

Die Entwicklung eines Embryos ist ein sehr komplexer Prozeß, der auf einem genetischen Programms basiert. Es besteht aus einer hierarchischen Anordnung regulierender Gene, die das Zellschicksal und die Differenzierung bestimmen (GANDOLFI, 1994).

Studien haben gezeigt, daß Eileiterzellen oder Eileiterflüssigkeiten speziesunspezifische Substanzen enthalten, die eine geeignete Umgebung für die Entwicklung porciner Embryonen darstellen. WISEMAN et al. (1992) finden in Eileiterflüssigkeit meßbare Konzentrationen der Wachstumsfaktoren Insulin-like growth factor I und II (IGF I und -II), die während des Östrus signifikant erhöht sind. Dabei verlaufen die Konzentrationen im Blutplasma und in der Eileiterflüssigkeit nicht parallel, so daß davon ausgegangen werden kann, daß beide Flüssigkeiten unabhängig voneinander gebildet werden.

Gonadotropin stimulierte Kumulus-Oozyten-Komplexe sezernieren das Mucopolysaccarid Hyaluronsäure (EPPIG, 1979b), das kurz vor der Befruchtung in die Eileiter entlassen wird. SATO et al. (1990) und MIYANO et al. (1994) berichten, daß Hyaluronsäure eine vitalitätsfördernde Aktivität auf Mäuse- und Schweineoozyten ausübt.

Den synthetischen Medien fehlen offensichtlich Faktoren, die eine synchrone Kernund Zytoplasmareifung ermöglichen (THIBAULT et al., 1975; MASUI \& CLARKE, 1985, EPPIG \& SCHROEDER, 1986; BÖTTCHER et al., 1992).

TSAFRIRI \& CHANNING (1975) beobachten, daß TCM199 mit zusätzlich Supplementierungen von Pyruvat, Lactat und Insulin bessere Reifungsraten erzielt als ohne.

Embryonen produzieren Faktoren, die ihre Entwicklung gegenseitig auf paracrine Weise unterstützt (TROUNSON et al., 1994). Eine zu geringe Menge an Embryonen in einer zu großen Mediummenge schlägt sich bei der Maus in reduzierten Entwicklungsraten nieder. Als optimal wird in der Untersuchung von KATO \& TSUNODA (1994) ein 1:1 Verhältnis (1 Embryo/1ul Medium) angesehen. Ein Ansteigen der Gruppengröße hat keinen negativen Effekt. Der Zusatz von EGF, TGF- $\alpha$ 
oder $-\beta$ hat einen stimulierenden Einflu $\beta$ auf die Embryoentwicklungsrate, so da $\beta$ die Autoren darauf schließen, daß diese Wachstumfaktoren als paracrine Faktoren in Frage kommen.

Alle Zellen der Säugetiere werden durch aktiven Sauerstoff, der gebildet wird, wenn molekularer Sauerstoff als Elektronenfänger während oxidativer Reduktionen der Zellen benutzt wird, geschädigt. Superoxid-Anionen sind die häufigsten Formen des aktiven Sauerstoffs, die durch viele Enzymsysteme gebildet werden. Superoxid Anionen reagieren mit Proteinen oder Lipiden (NODA et al., 1991). Sauerstoffradikale sind extrem reaktionsfreudig und schädigen die Zellen durch Fettperoxidation, Enzyminaktivierung und Beschädigungen der DNA (TROUNSON, 1992). RIEGER et al.(1992) betonen, daß diese Sauerstoffradikalbildung Embryonen in vitro massiv negativ beenflußt.

Es ist bekannt, daß reduzierte Sauerstoffspannungen $\left(\begin{array}{llllll}5 \% & \mathrm{O}_{2}, & 5 \% & \mathrm{CO}_{2}, & 90 \% & \mathrm{~N}_{2}\end{array}\right)$ während der Kultur durch die Reduktion von Sauerstoffradikalbildung (PEURA, 1993) sich sehr positiv auf die Entwicklungsrate von Schweinembryonen auswirken (FUNAHASI et al., 1994a). PINYOPUMMINTR \& BAVISTER (1994a, 1995) fordern für die Kultur von Rinderembryonen eine höhere Sauerstoffspannung von 20\%. Freie Radikale werden durch Enzyme wie Superoxid-Dismutase reduziert oder durch Radikalfänger wie Taurin eliminiert (LIU et al. 1995). Auch Glutathion spielt zum Schutz der Zellen gegen Sauerstoffschädigungen in der Zellkultur eine entscheidende Rolle (MEISTER \& ANDERSON, 1983, GRUPEN et al., 1995).

Der $\mathrm{CO}_{2}$-Begasung in Kombination mit einem bicarbonat-gepufferten Medium schreiben ENG et al. (1986) bei der IVM und IVF eine wichtige Rolle zu. $\mathrm{CO}_{2}$ wird vorwiegend in Aminosäuren und Proteinen inkorporiert. Dieses findet wahrscheinlich durch Pyruvat-Carboxylase gesteuerte Kondensation von Kohlendioxid zu Oxalacetat statt.

Studien von KANE (1975) zeigen, daß eine N-2-ㅂydroxyethyl Piperazin N'-2

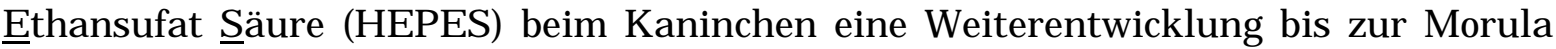
zwar unterstützt, eine Entwicklung bis zur Blastozyste allerdings nur mit Bicarbonat möglich war.

Untersuchungen von Eileiterflüssigkeit zeigen, daß sie hohe Bicarbonatkonzentrationen enthält (VISHWAKARMA, 1962; HAMNER, 1973; MAAS et al., 1977).

Eine Studie von WALKER et al. (1989) zeigt, daß der Zusatz von HEPES die Entwicklungskapazität von Embryonen in Langzeitkulturen drastisch reduziert. Zum einen hat HEPES einen direkten toxischen Effekt. Wenn HEPES-gepuffertes Medium 
Licht ausgesetzt wird, nimmt die Produktion zytotoxischer Produkte zu (ZAIGLER et al., 1985). Weiterhin führen die Autoren an, daß ein Ersatz von Natriumbicarbonat durch HEPES zu einer Imbalance der Bicarbonationen im Medium führt.

Die Inkubationstemperatur von Gameten ist von der Kerntemperatur der jeweiligen Spezies abhängig. LENZ et al. (1983) haben am Rind gezeigt, daß die körperähnlichen Inkubationstemperaturen bezüglich der Gameteninteraktion vorteilhafter sind als höhere oder niedrigere Temperaturen.

ENG et al. (1986) und TROUNSON (1992) bestätigen diese Aussage am Schwein und raten, daß in weiteren Studien die Kernkörpertemperatur beachtet werden sollte. So werden Schweinegameten von NAITO et al. (1989) und HAJDU et al. (1994) bei $39^{\circ} \mathrm{C}$ erfolgreicher als bei $37^{\circ} \mathrm{C}$ kultiviert

Hohe NaCl-Konzentrationen ohne Anwesenheit von Glutamin verhindern bei der Maus eine Embryonalentwicklung in vitro (TROUNSON et al., 1994). Für die verschiedenen Kultivierungsphasen porciner Oozyten und Embryonen gelten unterschiedliche Toleranzen bezüglich der Osmolarität. McGAUGHEY (1975; 1977) sowie FUNAHASHI et al., (1994b) berichten, daß eine Osmolarität von $305 \mathrm{mOsmol} / \mathrm{kg}$ bei der Kultivierung von Oozyten nicht überschritten werden sollte, da sonst eine nukleare Reifung nicht gewährleistet ist. REED et al. (1992) sehen allerdings keine Probleme bei der Kultivierung von Schweinembryonen bei hohen Osmolaritäten.

\subsubsection{Energetische Versorgung}

\subsection{Aminosäuren}

Die Anwesenheit von Aminosäuren im Medium ist für die Embryonalentwicklung als Energiequelle absolut notwendig (TROUNSON et al, 1994).

Neben Glutamin als Energielieferant (ROSENKRANS et al., 1989) agiert Taurin als ein Osmoregulator, indem es Zellen mit seiner antioxidativen Wirkung vor toxischen Substanzen schützt (SPINDLE, 1995, KANE et al., 1992). Taurin und sein Vorläufer Hypotaurin sind schwefelhaltige ß-Aminosäuren, die auch im weiblichen Reproduktionstrakt in großen Konzentrationen vorkommen (MEIZEL et al., 1980).

CHANG et al. (1976) untersuchten die Aminosäuregehalte in kleinen, mittleren und großen Follikeln sowie die Gehalte im Serum von Sauen. Bezüglich Taurin stellten sie

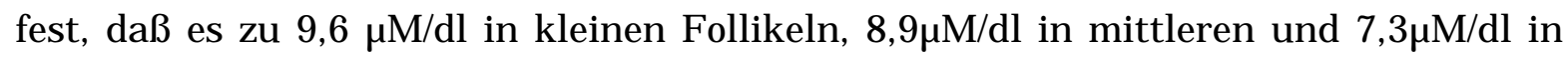
großen Follikeln enthalten ist. Das Serum enthält sogar $18 \mu \mathrm{M} / \mathrm{dl}$. 


\subsection{Glucose und Phosphat}

FLOOD \& WIEBOLD konnten 1988 zeigen, daß der frühe Schweineembryo (1-4-Zeller) den Pentose-Phosphat-Zyklus im Glucosemetabolismus nutzt. Die Glucose wird in den späteren Embryonalstadien wie Morula und Blastozyste auch durch die Glycolyse genutzt. Das Produkt der Glycolyse ist Pyruvat oder Lactat, die das embryonale Wachstum beim Schwein unterdrücken (DAVIS \& DAY, 1978).

Dihydrogenphosphat und Glucose haben in Kombination suppressiven Einfluß auf die Entwicklung des präimplantativen Embryos. Die biochemische Erklärung für dieses Phänomen liegt wohl in einer inadäquaten Energiebereitstellung infolge der Behinderung der mitochondrialen oxidativen Phosphorilierung begründet, die maßgebend die Quelle für das Adenosin-Triphosphat (ATP) darstellt (SCHINI \& BAVISTER, 1988; SESHAGIRI \& BAVISTER, 1989, PINYOPUMINTR \& BAVISTER, 1991). Phosphat ist durch seine Fähigkeit, drei glykolytische Enzyme zu aktivieren (Glukokinase, Phosphofruktokinase und Glyceraldehyd-3-Phosphat Dehydrogenase) stimulierend für die Glykolyse (WU, 1965), so daß ein Wettstreit mit der mitochondrialen Respiration entsteht. Man spricht hierbei auch vom Crabtree-Effekt (CRABTREE, 1929; KOOBS, 1972). Die Behinderung der Respiration resultiert in einer limitierten Energiebereitstellung, was sich wiederum in einem reduzierten embryonalen Wachstum niederschlägt.

PETTERS et al. (1990) konnten diese destruktiven Effekte bei der Kultivierung von Schweineembryonen in Gegenwart von Glucose und Phosphat nicht bestätigen.

\subsection{Serumalbumin}

Die Reinheit von BSA variiert stark zwischen den Chargen; die Reste von Fettsäuren im BSA könnten einen trophischen (ernährenden) Effekt auf die Embryonen ausüben. Die Arbeiten von MIYANO et al., (1994) zeigen, daß BSA sowohl inhibierende als auch stimulierende Faktoren auf die Embryonenentwicklung enthält.

EBERHARDT et al. (1994) erkennen, daß fettsäure-freies BSA (Cat. Nr. A-0281, Sigma Chemical Co., St. Louis, MO) aus einer 95\%igen Alkohohl Präparation bessere Ergebnisse bezüglich der Entwicklungsfähigkeit von Schweineembryonen zeigt, als das üblicherweise verwendete BSA Fraction V. BECKMANN (1991) kann für die porcine In-vitro-Entwicklung keine unterschied bezüglich der BSA-Chargen finden. 


\subsection{Wachstumsfaktoren}

Insulinrezeptoren existieren schon im frühen Embryo (WATSON et al, 1992). Durch Insulin wird der Aminosäuretransport (KAYE et al., 1986), die Mitose (GARDNER \& KAYE, 1991) und die Proteinsynthese (HARVEY \& KAYE, 1988; SAITO \& NIEMANN, 1991) unterstützt. Der Zusatz von Insulin zum Maturationsmedium verbessert die Kumulusexpansion und die Fertilisationsraten (ZHANG et al., 1991). Während THIBODEAUX et al., (1995) berichten, daß Insulin, Transferrin und Natriumselenit einen großen Einfluß auf die embryonale Proliferation ausüben, konnten EBERHARDT et al. (1994) diesen Effekt nur in Zusammenhang mit BSA erkennen. Auf der Zelloberfläche wird die Rezeptorenanzahl für Insulin-like-growth factor durch den Zusatz von Insulin gesteigert, so daß dem Insulin von GRAHAM et al. (1990) eine große Bedeutung bei der IVF zugesprochen wird.

DIAMOND et al. (1985) erkennt, daß eine hohe Insulinkonzentration im Follikel der Frau auf gut fertilisierbare Oozyten hinweist. DORINGTON et al. (1987) weisen darauf hin, daß IGF-I zu den lokalen Faktoren gehört, die von den Granulosazellen des Follikels selber gebildet werden und als Verstärker der Gonadotropinwirkung fungieren.

Transferrin wird die Fähigkeit zugeschrieben, Eisen in die Zelle zu transportieren. In Kombination mit Insulin und Natriumselenit kann es die Wirkung von Aminosäuren unterstützen (PRATTEN et al., 1988; ZHANG \& ARMSTRONG, 1990).

\subsection{Proteinzusätze}

Serum wird bei der In-vitro-Fertilisation als Proteinquelle eingesetzt. Dabei ist der Einfluß auf die Embryonenentwicklung beim Einsatz von östrischem Serum besser. BÖTTCHER et al. (1992) führen dies auf die hohen Östradiol- und Progesteronwerte im Vergleich zum sonst benutzten Kälberserum (FKS) zurück. Blutseren werden weiterhin zur Verhinderung der Klebrigkeit der Embryonen in der Zellkultur eingesetzt (PALASZ et al., 1995).

\subsubsection{Follikelflüssigkeit}

Die Follikelflüssigkeit ist das natürliche Milieu für das Wachstum und die Reifung der Oozyten im Follikel. Sie steht im ständigen Stoffaustausch mit dem Blut (EDWARDS, 1974). Die Zusammensetzung der Follikelflüssigkeit ändert sich während des 
Follikelwachstums nicht nur hinsichtlich ihres Eiweißgehaltes, sondern auch bezüglich ihres Hormongehaltes (DIELEMANN et al., 1983, MAURER \& WISE, 1990). Follikelflüssigkeit enthält hyaluronsäureähnliche Glycosaminoglykane, die die Vitalität porciner Oozyten in vitro erhalten (SATO et al., 1990) und somit die Anzahl degenerierter Oozyten reduzieren (MIYANO et al., 1994). Follikuläre Wachstumsfaktoren unterstützen das embryonale Wachstum in autokriner Weise. Diese Wachstumsfaktoren stehen mit den Gykosoaminoglykanen in positiver Interaktion und induzieren so eine höhere Zellproliferations- und Entwicklungsrate von Embryonen (SATO et al., 1991).

Weiterhin befinden sich in der Follikelflüssigkeit Immunglobuline, vorwiegend IgA. Die Gehalte sind bei Jungsauen höher als bei Altsauen. Die Funktion dieser Immunglobuline ist allerdings weitgehend unbekannt (HUSSEIN \& BOURNE, 1984). Es wird vermutet, daß sie die Oozyten zum Zeitpunkt der Ovulation vor Infektionen schützen (WHITMORE \& ARCHBALD, 1977).

Ein weiterer Effekt der Follikelflüssigkeit wurde von NAITO et al. (1988) sowie RATH et al. (1995) untersucht. Die Autoren erkannten, daß porcine Follikelflüssigkeit die Oozyten in eine verbesserte Befruchtungskonstitution überführen, so daß die Rate an männlicher Vorkernbildung nach IVF beim Schwein signifikant erhöht werden konnte. DING et al. (1992b) untersuchten die Hormongehalte in Follikelflüssigkeiten und fanden heraus, daß kleine Follikel höhere Testosteron- als Progesteronkonzentrationen aufweisen und bereits Östradiol enthalten.

Follikelflüssigkeit besteht zum größten Teil aus zuckerhaltigen Komponenten. Diese follikulären Glycosaminoglycane oder Mucopolysaccharide sind eine Mischung aus Chondroitinsulphat, Heparansulphat (NAITO et al., 1990), Dermatansulfat und Hyaloronsäure (WISE et al.,1994). Weiterhin enthalten sie N-Acetylglucosamine oder N-Acetygalctosamine (EDWARDS, 1974; AX \& RYAN, 1979; NAITO et al., 1990).

Die Kumulusexpansion wird den Glycosoaminoglykanen mit einem Molekulargewicht von $>200000$ in der Follikelflüssigkeit zugeschrieben. Sie sind 15 Minuten bei $100^{\circ} \mathrm{C}$ und 30 Minuten bei $56^{\circ} \mathrm{C}$ hitzebeständig und zeigen eine hohe Toleranz gegen wiederholtes Einfrieren und Auftauen (DAEN et al., 1994).

In-vitro-gereifte Schweineoozyten weisen eine geringe Fähigkeit auf, einen männlichen Vorkern auszubilden, es sei denn, sie wurden in porciner oder boviner Follikelflüssigkeit kultiviert. Die aktiven Faktoren sind also nicht spezies-spezifisch (NAITO et al., 1988, 1989; EPPIG \& SCHROEDER, 1986).

Trotzdem ergeben sich innerhalb der Literatur Unstimmigkeiten bezüglich des reifungsfördernden Effekts porciner Follikelflüssigeit. RACOWSKY \& McGAUGHEY 
(1982) erklären diese widersprüchlichen Angaben durch Unzulänglichkeiten der Färbemethoden in der Beurteilung der meiotischen Phasen. Sie finden weder in der Follikelflüssigkeit noch in den Membranen der Granulosa-Zellen OMIsynthetisierende Faktoren.

Dagegen ist es WESTERGAARD (1988) gelungen, in großen präovulatorischen Follikeln der Frau und des Rindes ein LH-Peak abhängiges Auftreten einer „MeiosisInducing-Substance“ (MIS) nachzuweisen.

\subsection{Kultursysteme}

Porcine Oozyten und Embryonen unterscheiden sich $\mathrm{zu}$ den Gameten anderer Säugetiere durch einen hohen Anteil an Fetten im Zytoplasma, so daß eine längere Invitro-Kultivierung diese Zellen alsbald erschöpfen läßt. Die Arbeit von YOUNGS et al. (1994) zeigt die Zusammensetzung einer in vivo entwickelten porcinen Blastozyte. Diese Embryonen weisen im Gegensatz zu anderen Säugetierembryonen hohe

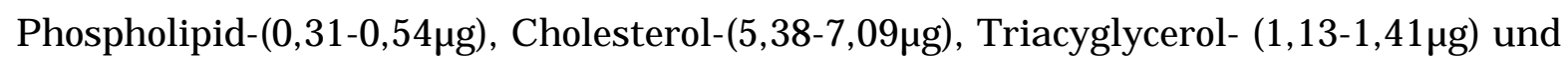
Fettsäurengehalte auf.

Somit müssen die Kulturbedingungen für unreife porcine Oozyten den hoch spezifischen Ansprüchen bezüglich des Lipidgehaltes der Zelle angepaßt werden (HOMA et al., 1986).

Lipide liefern nicht nur Nährstoffe für die Zelle, sondern spielen auch bei der Modifikation der physikalischen Eigenschaften und der biologischen Funktionen der Zellmembranen eine entscheidene Rolle (STUBBS \& SMITH, 1984). Auch die Fähigkeit vieler Membranproteine Hormonrezeptoren auszubilden, beruht auf der Zusammensetzung der Fettsäuremuster der Membranlipide (HIRATA et al., 1979).

\subsubsection{Kokultursysteme}

Eine Möglichkeit, Embryonenen zu kultivieren, ist der Einsatz von Kokultursystemen. Hierbei handelt es sich um sogenannte Helfer- oder Ammenzellen, die durch die Sezernierung von embryotrophen Faktoren ins Kulturmedium die Vitalität der kultivierten Zellen unterstützten.

Neuere Arbeiten von BEHBOODI et al. (1995) und GROCHOLOVÁ et al. (1995) haben abermals gezeigt, daß sich Kokultursysteme unterstützend auf die Vitalität von Säugerembryonen auswirken können.

KANE et al. (1992) schreiben Kokultursystemen drei hauptsächliche Eigenschaften zu: 
1. Die Helferzellen produzieren mitogene Substanzen (Gewebe-spezifische und/oder nicht spezifische embryotrophe Substanzen) für die Embryonen.

2. Sie liefern ein weites Spektrum an Faktoren, die die embryonale Zelldifferenzierng unterstützen.

3. Sie nehmen embryotoxische Substanzen aus dem Kulturmedium auf.

Embryo-suppressive Substanzen wie Glucose (TAKAHASHI \& FIRST, 1992), Hypoxanthine (LOUTRADIS et al., 1987), Phosphat (PINYOPUMMINTR \& BAVISTER, 1991) oder Sauerstoff (RIEGER, 1992) werden entfernt oder inaktiviert.

Der Anteil fragmentierter Blastomeren ist in Kokultursystemen reduziert (SCHINI \& BAVISTER, 1988, BONGSO et al, 1989; WIEMER et al., 1989).

Kokultursysteme sind für viele praktische Ansätze nützlich. Allerdings ist das Spektrum der sezernierten Faktoren nicht bestimmbar, so daß aufgrund dieser Systeme keine genauen Angaben über die Ansprüche des Embryos in vitro geäußert werden können (PEURA, 1993).

Somatische Zellen als Feederlayer können die Embryoentwicklung durch eine Konstanthaltung leicht varierender physio-chemischer Bedingungen positiv beeinflussen (BAVISTER, 1992).

\subsubsection{Eileiterfeederzellen als Kokultur}

Porcine Eileiterzellen sezerniernen neben IGF-1 und IGF-2 auch EGF in das Kulturmedium (HENDRICKS \& LEE, 1992; WEISMAN et al., 1992) und unterstützen so die Weiterentwicklung von Embryonen auch über den In-vitro-Zellblock hinweg (GANDOLFI \& MOOR, 1987; REXROAD, 1989; WHITE et al., 1989).

Dabei spielt der sezernierte Wachstumsfaktor EGF in der porcinen IVF eine besondere Rolle. ARELLANO et al. (1993), SINGH \& ARMSTRONG (1994) und IM \& PARK (1995) bestätigen, daß die Anwesenheit des Epidermal growth factor (EGF) in vitro sowohl die Maturation porciner Oozyten als auch deren Kumulusexpansion verbessern kann. Die Autoren stellen EGF in der Oozyte, im Kumulus und in den Granulosazellen fest. So konnte nachgewiesen werden, daß EGF Polyspermie verhindern kann und die Ausbildung normaler Pronuclei unterstützt. Untersuchungen mit Eileiterflüssigkeit zeigen ähnlich positive Einflüsse. Eileiterflüssigkeit stellt ein physiologisches Medium für die Befruchtung und frühe Embryonalentwicklung dar (HUNTER, 1990). Hier ist die Aminosäure Glycin die Hauptkomponente (IRITANI et al., 1974).

Eileiterkokulturen sezerniern die embryo-vitlitätsfördernde Hyaluronsäure ins Zellkulturmedium (CARNEY et al., 1990; MIYANO et al.,1994). 
Der Eileiterfeederlayer liefert in den Untersuchungen von CHOI et al. (1995) signifikant bessere Ergebnisse bezüglich der Entwicklungsrate von Schweineembryonen. DUMOULIN et al. (1992) und MEIZEL et al. (1980) finden hohe Konzentrationen der Aminosäure Taurin in der Eileiterflüssigkeit von Mäusen, NARIMOTO et al. (1991) entdeckten Superoxiddismutase in der Eileiterflüssigkeit.

BAVISTER (1988) und KRISHER et al. (1989a,b) bestätigen KANE et al. (1992), daß Eileiterzellen eine wichtige Rolle bei der Entfernung toxischer Substanzenen aus der Nähe des frühen Embryos spielen. Auch GANDOLFI et al. (1993) sehen durch die Eileiterzellen einen Schutz vor toxischen Substanzen, sowie einen stimulierenden Effekt durch die Anwesenheit von hohen Konzentrationen Hypotaurin (KAYE, 1986), Superoxiddismutase (NODA et al. 1991; NARIMOTO et al.,1991) und Transferrin (NASR-ESFAHANI \& JOHNSON, 1992).

Der förderliche Effekt der Eileiterzellen ist nicht Spezies-spezifisch (WHITE et al., 1989; PAVASUTHIPAISIT et al., 1994). NAGAI \& MOOR (1990) finden reduzierte Vorkommen von Polyspermie, wenn die Fertilisation in Anwesenheit von Eileiterzellen stattfindet. Grund dafür soll ein löslicher Faktor sein, der aus der Eileiter-Kokultur stammt und die Anzahl der Spermien, die die Oozyte penetrieren, senkt (KANO et al., 1994). NAGAI \& MOOR (1990) stellen weiterhin die Hypothese auf, daß eine Kombination von einer Kokultur mit Eileiterzellen und Follikelflüssigkeit, die Polyspermierate noch weiter reduzieren kann. KRISHER et al. (1989 a,b) benutzten Mäuseeileiter in einer In-vitro-Organkultur, um frühe Embryonen des Schweines bis zum Blastozystenstadium zu überführen.

Das Zyklusstadium der Eileiterspendertiere hat einen Effekt auf die Morphologie und die Vitalität der Eileiterzellen. Beim Rind ist die Gewinnung am 4. - 6. Zyklustag bezüglich der Benutzung als Kokulturzellen am günstigsten (THIBAUDEAUX et al., 1991b).

Ein weiterer förderlicher Effekt durch die Kokultur mit Eileiterzellen könnte die Reduzierung der Sauerstoffkonzentration im Medium durch die Zellen sein ( NAGAO et al., 1994).

Eileiterzellen sezernieren einen spezifischen Faktor wie das $97 \mathrm{Kda}$ östrus-assozierte Glycoprotein (MALAYER et al., 1988; BOICE et al., 1990; GERENA \& KILIAN, 1990). Dieses Glycoprotein bindet an den Embryo und verbessert somit seine Entwicklungskapazität (BOICE et al., 1992).

Auch nicht spezifische Wachstumsfaktoren werden vom Eileiter gebildet. WATSON et al. (1992) berichten über die Produktion von Plateled-derived-growth-factor (PDGF), Aktivin, Insulin-like growth-factor (IGF) und basic Fibroblast growth factor (bFGF). 


\subsubsection{Buffalo-Rat-Liver-Zellen als Feederlayer}

BRL-Zellen in Form eines Feederlayers unterstützen die Entwicklung von Rinderembryonen (LIU et al., 1995). Auch REHMANN et al. (1994) zeigen, daß die BRL-Zellen als eine kommerziell erwerbliche Zellinie eine gute Alternative zu einer Eileiterzellkokultur bezüglich der Entwicklung von Rinderembryonen darstellt. Sie führen den embryotrophen und embryoregulierenden Einfluß der BRL-Zellen auf die Sekretion eines weiten Spektrums an Faktoren zurück.

BRL-Zellen synthetisieren den Leukaemia inhibitory factor (LIF; KURZROCK et al., 1991), den Transforming growth factor- $\beta$ (TGF; MASSAGUÉ et al., 1985) und haben eine „Multiplication stimulating activity“ (MSA; DULAK \& TEMIN, 1973). Die MSA ist sowohl strukturell als auch funktionell dem IGF II ähnlich (MARQUARDT et al., 1988). Es handelt sich um eine Polypeptid-Familie, die der im Serum vorhandene Multiplication Stimulating Activity identisch ist und die Proliferation serumabhängiger Zellen in serum-freien Medien unterstützten (DULAK \& TEMIN, 1973).

\subsection{Beurteilungsmöglichkeiten der Embryonenqualität}

\subsubsection{Morphologische Beurteilung}

Zumeist erfolgt eine Beurteilung der Embryonenqualität durch eine subjektive Klassifizierung ihres morphologischen Erscheinungsbildes in Anlehnung an LINDNER \& WRIGHT (1983) und KAUFFHOLD \& THAMM (1985). Die Blastomerenanzahl und deren Kompaktheit im einzelnen Embryo wird hierzu herangezogen. Allerdings führen diese Beurteilungsparameter gerade bei Schweineembryonen zu Fehldeutungen. Sehr oft liegt eine große Anzahl an Blastomeren vor, die jedoch Degenerationserscheinungen nach Fragmentation oder auch parthenogenetischen Ursprungs sein können. Es gilt also, die Anzahl vitaler Blastomeren durch ihre mitotisch aktiven Kerne in einem lebenden Zytoplasma zu bestätigen.

\subsubsection{Beurteilung durch Essisäure/Alkohol-Präparation}

WURTH et al. (1994) unterscheiden mittels der Aceto-Orcein Färbung nach Fixierung in Essigsäure/Alkohol zwischen pyknotischen und mitotisch aktiven Kernen. Eine Methode zur Präparation der Metaphase-Chromosomen wurde von MIZOGUCHI \& DUKELOW (1981) vorgestellt. Es handelt sich dabei um eine sehr elegante Giemsa- 
Färbetechnik, die eine Präparation des Karyotypes ohne Zerreißen der zytoplasmatischen Membranen erlaubt.

\subsubsection{Fluoreszenzfärbung mit Hoechst A 33342}

Das DNA-spezifische Fluorochrome Hoechst A 33342 kann zur Sichtbarmachung von Chromatin in Oozyten und Embryonen genutzt werden. Es handelt sich hierbei um den Fluoreszenzfarbstoff Benzimid, 2-[4Hydroxyphenyl]-5-[4-methyl-1-piperazinyl] 2,5’bi-1H-bizimidazole (Sigma, Steinheim). Mittels dieser Methode ist es möglich, nach vorangegangener morphologischer Beurteilung von Embryonen die Anzahl der Kerne zu kontrollieren (VIUFF et al., 1991). Mitotisch aktive Kerne können als hellblaue, scharf umrandete Strukturen identifiziert werden.

\subsubsection{Fluoreszenzfärbung mit FDA}

Eine Vitalitätsbeurteilung mittels FDA (3`6-Fluorescein-Diacetate) wurde bereits in den 70er Jahren von SCHILLING et al. beschrieben (SCHILLING \& DÖPKE, 1978; SCHILLING et al., 1979, SCHILLING \& SMIDT, 1979). Mit Hilfe dieser Färbemethode ist es möglich, sowohl die Integrität der embryonalen Plasmamembranen als auch eine zytoplasmatische Enzymaktivität nachzuweisen Lebensfähige Embryonen entwickeln nach nur kurzer Inkubationszeit in diesem Fluochrom nach UV-Anregung eine leuchtend hellgrüne Fluoreszenz, während tote Embryonen keine Farbreaktion aufweisen. 


\subsection{Material und Methoden}

\subsection{Tiermaterial}

Ausgangsmaterial für die Gewinnung unreifer Oozyten waren pathologisch nicht veränderte Ovarien nicht tragender Jungsauen vom lokalen Schlachthof. Es handelte sich also um Eierstöcke in der Follikelphase ohne Corpora lutea oder Corpora albicantia. Die peripuberalen Spendertiere mit einem durchschnittlichen Gewicht von 100-130 kg wurden der routinemäßigen Schlachtkette zugeführt.

Nach Abtrennung der Ovarien vom Genitaltrakt wurden sie in $500 \mathrm{ml}$ Transportmedium mit Antibiotika (100I.E./ml Penicillin; 100 $\mu \mathrm{g} / \mathrm{ml}$ Streptomycin, Gibco BRL, Eggenstein, Vgl. Kap. 3.2.1.) im Thermosgefäß bei $25-30^{\circ} \mathrm{C}$ zwischengelagert und innerhalb von zwei Stunden ins Labor transportiert.

\subsection{Medien}

Da im Rahmen dieser Arbeit ein sehr großes Spektrum an Medien verwendet wurde, sollen im Folgenden die einzelnen Formulierungen der verschiedenen Medien beschrieben werden. Bei der Medienherstellung wurde nur Reinstwasser (Ampuwa, Fresenius AG, Bad Homburg) mit geringer elektrischer Leitfähigkeit verwendet, so daß einer Kontamination mit mit Elektrolyten wie Metallionen vorgebeugt wurde (NAGAO et al., 1995). Alle Chemikalien wurden von der Firma Sigma, Deisenhofen bezogen und waren zellkulturgetestet. Andere Firmenprodukte sind ausgewiesen.

\subsubsection{Transport - und Waschmedium für Ovarien und Oozyten}

PBS (Phosphate buffered saline) diente ohne FKS (Fetales Kälberserum) als Transport- und mit 2\% FKS als Waschmedium und wurde nach folgendem Rezept selbst hergestellt: 
Tabelle 1.: Zusammensetzung des PBS - Mediums.(DULBECCO \& VOGT, 1953)

\begin{tabular}{cc}
\hline Komponenten & $\begin{array}{c}\text { Menge } \\
\mathrm{mg} / \mathrm{l} \text { Ampuwa }\end{array}$ \\
\hline Lösung I (800ml) & 8000 \\
$\mathrm{NaCl}$ & 200 \\
$\mathrm{KCl}$ & 1150 \\
$\mathrm{Na}_{2} \mathrm{HPO}_{4}$ & 200 \\
$\mathrm{KH}_{2} \mathrm{PO}_{4}$ & \\
$\underline{\text { Lösung II (100ml) }}$ & 100 \\
$\mathrm{CaCl}_{2}$, wasserfrei & \\
Lösung III (100ml) & 100 \\
$\mathrm{MgCl}_{2}$ x $6 \mathrm{H}_{2} \mathrm{O}$ & \\
\hline
\end{tabular}

Lösung I, II und III wurden separat angesetzt und im Autoklaven (112, KSG, Olching) autoklaviert. Nach Abkühlung der drei Komponenten wurden sie miteinander vermischt und ergaben insgesamt ein Volumen von $1000 \mathrm{ml} .100 \mathrm{mg} / \mathrm{l}$ sterile Calciumchloridlösung und $70 \mu \mathrm{g} / \mathrm{ml}$ Kanamycin wurden supplementiert. Der pH-Wert wurde mit $1 \mathrm{M} \mathrm{NaOH}$ bzw. $\mathrm{HCl}$ und einem Digital-pH-Meter (pH 526, WTW, Weilheim) mit Ingold Meßelektrode (Inlab 423, pH Einstabmeßkette $60 \mathrm{~mm}$, Steinbach/Taunus) auf pH 7,4 eingestellt. Die Osmolarität (Osmomat 030, Gonotec, Knauer, Berlin) des Ovartransportmediums betrug $280 \mathrm{mOsm} / \mathrm{kg}$.

Das Waschmedium für die Oozyten ( $\mathrm{pH} 7,4,280 \mathrm{mOsm} / \mathrm{kg})$ wurde zusätzlich mit $2 \%$ FKS supplementiert und mit einer Millipore Druckfiltrationseinheit mit Filtropur 0,2 $\mathrm{S}$ - Glockenfiltern (Sarstedt, Nümbrecht) steril filtriert und bei $5^{\circ} \mathrm{C}$ in $100 \mathrm{ml}$ Portionen in dunklen Flaschen über maximal 4 Wochen im Kühlschrank bei $5-8^{\circ} \mathrm{C}$ aufbewahrt. 


\subsubsection{Maturationsmedium}

10ml TCM199 mit Earle`s Salts und L-Glutamin (Tissue Culture Medium 199,

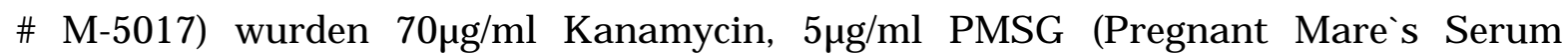
Gonadotropin, Intergonan , Intervet, Toenisvorst) und $2 \mu \mathrm{g} / \mathrm{ml}$ hCG (human Choronic Gonadotropin, Ovogest, Intervet, Toenisvorst), $10 \mu \mathrm{l} / \mathrm{ml}$ einer Insulin ( $5 \mu \mathrm{g} / \mathrm{ml})$ -

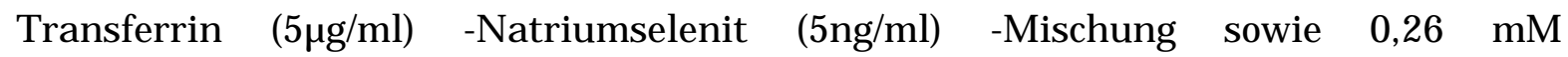
Natriumpyruvat zugesetzt. Das Reifungsmedium wurde auf eine Osmolarität von $280 \mathrm{mOsm} / \mathrm{kg}$ eingestellt wurde. Als Puffersystem dienten 25mM $\mathrm{NaHCO}_{3}$.

Dieses Medium wurde mit 10\% Protein unterschiedlicher Herkunft supplementiert. Dazu gehörten porcine Follikelflüssigkeit (pFF), Hitze-inaktiviertes östrisches Ziegenserum (ZS) und Fetales Kälberserum (FKS). ZS und pFF wurden weiterhin unterschiedliche Konzentrationen antiinhibinhaltigen Ziegenserums (Anti-INH) zugefügt. Weitere Versuchsansätze beinhalten den Einsatz von Eileiter- bzw. BRLFeederlayern in Kombination mit unterschiedlichen Proteinquellen.

Vor der Benutzung wurde das jeweilige Medium mit einem 0,2 $\mu$ m Spritzenfilter (Sarstedt, Nümbrecht) in Vierlochschalen (Nunc, Wiesbaden, GLW, Würzburg) steril filtriert und im Brutschrank bei $39^{\circ} \mathrm{C}$ und $5 \% \mathrm{CO}_{2}$ für mindestens zwei Stunden auf einen $\mathrm{pH}-$ Wert von 7,4 äquilibriert. 


\subsubsection{Waschmedium für Spermatozoen}

Einen Tag vor Gebrauch wurde physiologische Kochsalzlösung (0,9\% NaCl) mit 0,1\% BSA (,Bovines S Serum Albumin Fraction V, Sigma, Deisenhofen, \# A-9647) und 70 $\mu \mathrm{g} / \mathrm{ml}$ Kanamycin (Sigma, Deisenhofen) supplementiert. Der pH-Wert der Waschlösung wurde mit 0,01M HCl auf 7,2 eingestellt. Das Medium wurde mit 0,2 $\mu \mathrm{m}$ Filtropur S - Filtern (Sarstedt, Nümbrecht) steril filtriert und in lichtundurchlässigen sterilen 100ml Glasflaschen mit Stopfen und Parafilm (GLW, Würzburg) bis zum Gebrauch bei $5-8^{\circ} \mathrm{C}$ im Kühlschrank aufbewahrt.

\subsubsection{Kapazitationsmedium}

50ml TCM199 mit L-Glutamin (Sigma, Deisenhofen, \# M-5017) wurde mit 70 $\mathrm{g} / \mathrm{ml}$ Kanamycin (Sigma, Deisenhofen), 2,92 mM Calciumlaktat (Sigma, Deisenhofen), 0,91 mM Natriumpyruvat (Sigma, Deisenhofen) und 3,05 mM D-Glucose (Sigma, Deisenhofen) angereichert. Als Serumkomponente wurde Hitze-inaktiviertes FKS (Fetales Kälberserum, Gibco BRL, Eggenstein) eingesetzt. Das Medium wurde mit 0,2 $\mu \mathrm{m}$ Filtropur S - Filtern (Sarstedt, Nümbrecht) steril filtriert und in lichtundurchlässigen sterilen 100ml Glasflaschen mit Stopfen und Parafilm bis zum Gebrauch bei $5-8^{\circ} \mathrm{C}$ im Kühlschrank aufbewahrt.

\subsubsection{Befruchtungsmedium}

Das Befruchtungsmedium entsprach bis auf den Zusatz von 2,01mM Caffein (Sigma, Deisenhofen) dem Kapazitationsmedium. Caffein wurde erst 40 Minuten vor Gebrauch des Mediums hinzugefügt. Das Medium wurde mit 0,2 $\mu$ m Filtropur S-Filtern (Sarstedt, Nümbrecht) steril filtriert.

30 Minuten vor Insemination der Oozyten wurde das Befruchtungsmedium mit Caffein im Brutschrank bei $5 \% \mathrm{CO}_{2}, 39^{\circ} \mathrm{C}$ und $100 \%$ Luftfeuchte äquilibriert, nachdem es bereits ohne Caffein über Nacht im Brutschrank aufbewahrt worden war.

\subsubsection{Medien der frühen Embryokultur}

Es wurde ein modifiziertes Krebs-Ringer-Medium (№rth $\underline{\text { Carolina }}$ South $\underline{\text { United, }}$ NCSU-23)- für die In-vitro-Kultivierung in vitro fertilisierter Schweineembryonen 
verwendet. Das Medium enthielt die Aminosäuren Glutamin, Taurin und Hypotaurin (PETTERS et al., 1990; PETTERS \& REED, 1991; ILLERA et al., 1992).

\subsubsection{NCSU-23}

500ml Ampuwa (Fresenius AG, Bad Hamburg) wurden 114,73mM NaCl (Sigma, Deisenhofen), 4,78mM KCl (Sigma, Deisenhofen), 1,70mM CaCl 2 (Sigma, Deisenhofen) wasserfrei, $1,19 \mathrm{mM} \quad \mathrm{KH}_{2} \mathrm{PO}_{4} * 2 \quad \mathrm{H}_{2} \mathrm{O}$ (Sigma, Deisenhofen), $1,19 \mathrm{mM} \quad \mathrm{MgCl}_{2} * 7 \mathrm{H}_{2} \mathrm{O}$ (Sigma, Deisenhofen) und 25,07mM $\mathrm{NaHCO}_{3}$ (Sigma, Deisenhofen)zugesetzt. Diese NCSU-23-Basislösung wurde steril filtriert und bei $5-8^{\circ} \mathrm{C}$ im Kühlschrank gelagert.

Vor Gebrauch des Kulturmediums wurden 5,5mM Glucose (Sigma, Deisenhofen), 4\% BSA (Sigma, Deisenhofen), 10\% FKS (Gibco BRL, Eggenstein), 7,0mM Taurin (Sigma, Deisenhofen), 5,0mM Hypotaurin (Sigma, Deisenhofen), 1,0mM Glutamin (Sigma, Deisenhofen) sowie $5 \mu \mathrm{g} / \mathrm{ml}$ Insulin (Sigma, Deisenhofen) und Transferrin (Sigma, Deisenhofen) als auch 5ng/ml Natriumselenit (Sigma, Deisenhofen) hinzugefügt. Dieses komplette Medium wurde mit einem 0,2um Spritzenfilter steril filtriert. Jeweils $400 \mu \mathrm{l}$ des Embryokulturmediums wurden in 4-Loch Schalen (NUNC, Wiesbaden, GLW, Würzburg) gegeben und für mindestens 4 Stunden im Brutschrank bei $5 \% \mathrm{CO}_{2}$, $39^{\circ} \mathrm{C}$ und $100 \%$ Luftfeuchte äquilibriert.

\subsection{Eigene Untersuchungen zur In-vitro-Maturation porciner Oozyten}

Die im Folgenden vorgestellten Versuche sowie die Etablierung von Methoden erstreckten sich über einen Zeitraum von 3 1/2 Jahren.

Es wurden insgesamt 10011 Oozyten der Klassen I und II aus Schweineovarien vom Rosdorfer Schlachthof gewonnen.

In allen Versuchen wurden die Oozyten nach Gewinnung aus den Ovarien klassifiziert. Es wurden nur Oozyten der Klassen I und II (vgl. Kap. 3.4.1.) in die Versuchsgruppen aufgenommen. In Versuch 1 und 2 wurden die Oozyten auch nach der Reifung aufgrund ihres morphologischen Erscheinungsbildes der Kumulusexpansion erneut beurteilt. Hierbei wurde die Intensität der Expansion des Kumulus oophorus beurteilt (vgl. Kap. 3.6., Abb. 1). Innerhalb der ersten 4 Versuche wurde weiterhin das Erreichen der Metaphase II, also eine abgeschlossene nukleare Reifung der Oozyten beurteilt. Dazu wurde für die Versuche 1 und 2 die Giemsa-Färbung herangezogen, die dann von der Lacmoid-Färbung abgelöst wurde. 
Alle weiteren Versuche beschäftigten sich schwerpunktmäßig mit der Befruchtungsfähigkeit in vitro gereifter Oozyten, wobei im 5. und 6. Versuch lediglich die morphologisch bestimmte Teilungsrate erfaßt wurde. Erst in den sich anschließenden Versuchen wurden die Hoechst- und FDA-Färbungen herangezogen, um genauere Aussagen über die Embryonenqualität zu erhalten.

\subsection{Gewinnung der Oozyten}

Klare, gut durchblutete Follikel mit einem Durchmesser von 2-6mm wurden in einer auf der Wärmeplatte (Medax, Schütt,Göttingen, $39^{\circ} \mathrm{C}$ ) stehenden Petrischale (Greiner GmbH, Frickenhausen, Durchmesser 100mm) mit einer Skalpellkinge in $10 \mathrm{ml}$ Waschmedium angeschnitten (Tabelle 1). Die Oozyten aus jeweils 10 Ovarien gelangten auf diese Weise mit der Follikelflüssigkeit in das Waschmedium.

Das Waschmedium wurde dann mit einer sterilen Pasteurpipette aus der Petrischale in ein steriles, im $39^{\circ} \mathrm{C}$ warmen Wasserbad stehendes Reagenzglas pipettiert. Nach dem Absinken der Oozyten wurde fast der gesamte Überstand aus dem Reagenzglas verworfen und durch frisches, $39^{\circ} \mathrm{C}$ warmes Waschmedium ersetzt.

Nach 7 Minuten wurde dann das Sediment unter einem Mikroskop (M8, Wild

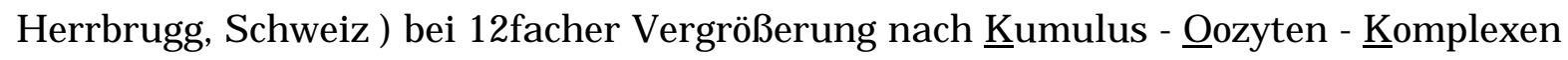
(KOK) durchsucht. Nur Oozyten mit nicht expandiertem Kumulus oophorus wurden mit Hilfe einer 140 $\mu$ m feinen, ausgezogenen Pasteurpipette mit Maturationsmedium dreimal gewaschen und in die Kultur des jeweiligen Versuchsansatzes überführt. Anschließend wurden mindestens 20 Kumulus-Oozyten-Komplexe in einer Vierlochschale in 400 $\mu$ l Maturationsmedium für 46 Stunden im Brutschrank (Water Jacketed Incubator, Forma Scientific, USA) bei $39^{\circ} \mathrm{C}$ und $5 \% \mathrm{CO}_{2}$ kultiviert. Das Medium wurde jeweils mit 400ul Mineralöl (\# M-8410, Sigma, Deisenhofen) überschichtet.

Von der Gewinnung der Oozyten bis zum Beginn der In-vitro-Maturation vergingen weniger als zwei Stunden. 


\subsubsection{Klassifizierung der Kumulus - Oozyten - Komplexe}

Die Klassifizierung der Kumulus - Oozyten - Komplexe wurde in Anlehnung an LEIBFRIED und FIRST (1979) anhand der unterschiedlichen Anzahl von Kumuluszellschichten durchgeführt.

Kategorie I: Oozyten, die von einem kompakten, nicht expandierten Kumulus oophorus mit drei oder mehr Zellschichten umgeben sind und ein gleichmäßig granuliertes Zytoplasma haben .

Kategorie II: Oozyten mit einem kompakten nicht expandierten Kumulus oophorus von weniger als drei Zellschichten und teilweise ungleichmäßiger Granulation des Zytoplasmas.

Kategorie III: Oozyten, die lediglich von der Corona radiata umgeben sind.

Kategorie IV: Oozyten ohne anhaftende Zellschichten an der Zona pellucida.

Für die Versuche wurden nur Oozyten der Kategorien I und II verwendet.

\subsection{Proteinquellen}

Innerhalb dieser Arbeit wurden die Effekte unterschiedlicher Proteinquellen in Form von Blutseren, Follikelflüssigkeit oder Feederlayern allein und in Kombination auf die nukleare Reifung von Schweineoozyten und die Weiterentwicklung von befruchteten Schweineoozyten untersucht.

\subsubsection{Fetales Kälberserum (FKS)}

Das FKS-Serum (Gibco BRL, Eggenstein) wurde kommerziell in 500ml Portionen tiefgefroren bezogen. Das gefrorene Serum wurde nach Antauen der Kontaktfläche zwischen Glasflasche und Serum mit $60^{\circ}$ warmen Wasser in einem $37^{\circ} \mathrm{C}$ warmen Wasserbad bis zur vollständigen Verflüssigung aufgetaut (Biochrom NEWS, 1995) und unter der Reinraumwerkbank in kleine Glasfläschchen steril zu 5 und $10 \mathrm{ml}$ portioniert, mit Stopfen und Parafilm (GLW, Würzburg) luftdicht verschlossen und bei $-20^{\circ} \mathrm{C}$ bis zum Gebrauch tiefgefroren. 


\subsubsection{Porcine Follikelflüssigkeit}

Die Ovarien peripuberaler Jungsauen wurden auf dem Rosdorfer Schlachthof innerhalb von 60 Minuten nach der Tötung der Tiere gewonnen und in $500 \mathrm{ml} 4^{\circ} \mathrm{C}$ kaltem PBS-Medium mit 5ml Penicillin/Streptomycin Lösung (= 100I.E./ml Penicillin; $100 \mu \mathrm{g} / \mathrm{ml}$ Streptomycin, Gibco BRL, Eggenstein) aufbewahrt. Nach 2-21/2 Stunden wurden Follikel einer Größe von 2-6mm mit einer $5 \mathrm{ml}$ Spritze und einer 21g Kanüle punktiert und die Follikelflüssigkeit aspiriert. Die Follikelflüssigkeit wurde in auf $4^{\circ} \mathrm{C}$ abgekühlten 10ml Reagenzgläsern gesammelt und für 30 Minuten bei $600 \mathrm{x} \mathrm{g}$ und $4^{\circ} \mathrm{C}$ zentrifugiert. Der Überstand aus allen Reagenzgläsern wurde in ein steriles Becherglas gegeben und in sterilen Glasfläschchen mit Stopfen und Parafilm bei $-20^{\circ} \mathrm{C}$ bis zur Verwendung portioniert tiefgefroren.

\subsubsection{Nicht Hitze-inaktiviertes Ziegenserum}

Einer in der Brunst befindlichen weibliche Burenziege mit einem Progesteronwert $<0,1 \mathrm{ng} / \mathrm{ml}$ wurden aus der Vena jugularis 50ml Blut entnommen. Das in einem 50mlRöhrchen befindliche Blut wurde über Nacht bei $4^{\circ} \mathrm{C}$ aufbewahrt und am nächsten Tag zweimal bei 500 x g für 20 Minuten in einer Zentrifuge (Labofuge III, Heraeus Christ, Osterode a. Harz) zentrifugiert. Das erhaltene Serum wurde in Eppendorfgefäße zu je $1 \mathrm{ml}$ portioniert und bei $-20^{\circ} \mathrm{C}$ bis zur Verwendung tiefgefroren.

\subsubsection{Gewinnung des Anti - hInhibin- $\alpha$ Ziegenserums}

Inhibin verhindert das Voranschreiten der Meiose vom Stadium des germinalen vesikulums bis zur Metaphase II und senkt die Befruchtungsfähigkeit der Oozyten. Innerhalb dieser Arbeit sollte mittels eines Antikörpers gegen Inhibin das Inhibin von und aus den Granulosazellen abgefangen und somit seine Aktivität neutralisiert werden. Der Antikörper gegen Inhibin (Anti- Inhibin) akkumuliert sich im Serum, das von Ziegen stammt, die gegen Inhibin immunisiert worden waren

Die Immunisierung geschah an weiblichen Burenziegen der institutseigenen Herde. Sie wurden zu Beginn der Paarungssaison mit rekombinantem humanem hINH $\alpha$ (Pharmacia Genetic Engineering, La Lolla, CA) behandelt. Das Antigen (100ug hINH $\alpha$ / Ziege) wurde in 5.5M Urea - 0.1 M Tris (pH 8) in Emulsion mit Freund's Adjuvants (Gibco BRL, Eggenstein) intramuskulär appliziert. Das Blut der immunisierten Ziegen 
wurde mittels ELISA auf den Inhibin-Antikörpertiter untersucht (HENNIES et al.,1992).

Für den vorliegenden Versuch wurde das Serum eines Tieres ausgewählt, das sowohl eine gute Antikörperreaktion (hoher Antikörpertiter im ELISA) als auch eine deutlich erhöhte Ovarreaktion aufwies. Um einer Zerstörung der gebildeten Antikörper gegen Inhibin im Blutserum vorzubeugen, wurde auf die sonst übliche Seruminaktivierung durch Erhitzung auf $56^{\circ} \mathrm{C}$ für 30 Minuten (CHANG, 1949) verzichtet.

Zur Herstellung des Kontrollserums wurde eine östrische, weibliche Ziege ausgewählt, die nicht mit Inhibin behandelt war und sich in Brunst befand. Der Progesteronwert im Blut betrug $<1 \mathrm{ng} / \mathrm{ml}$ Serum.

Aus der Vena jugularis wurden $200 \mathrm{ml}$ Blut in sterilen $50 \mathrm{ml}$ Röhrchen aufgefangen. Nach ca. 3 Stunden bei Raumtemperatur wurde das Blut bei $4^{\circ} \mathrm{C}$ über Nacht aufbewahrt. Am folgenden Tag wurde das Serum zweimal für $20 \mathrm{~min}$ bei $500 \mathrm{x} \mathrm{g}$ zentrifugiert. Die Hälfte des Serums wurde bei $56^{\circ} \mathrm{C}$ für $30 \mathrm{~min}$ im Wasserbad hitzeinaktiviert. Anschließend wurden die Ziegenseren, dem Versuchsaufbau entsprechend, gemischt und in 1 ml-Portionen bei $-20^{\circ} \mathrm{C}$ bis zur Verwendung tiefgefroren.

\subsection{Einfluß von fetalem Kälberserum (Versuch 1)}

In diesem Versuch (Tabelle 2) wurde der Zusatz von Fetalem Kälberserum (FKS) in unterschiedlichen Konzentrationen (0, 1, 5 und 10\%) zum Reifungsmedium untersucht und mit Hilfe der Giemsa-Färbung das Erreichen der Metaphase II (Maturationsrate = Anzahl Metaphase II-Oozyten/Anzahl kultivierte Oozyten * 100). beurteilt. Vor Beginn der Kultivierung wurden die Oozyten nach ihrem morphologischen Erscheinungsbildes in vier Güteklassen unterteilt.

Nach Beendigung der In-vitro-Reifungsphase erfolgte zuerst eine morphologische Beurteilung des expandierten Kumulus oophorus und Klassifizierung in vier Kategorien (I= sehr gute Expansion des Kumulus; II= gute Expansion des Kumulus; $\mathrm{III}=$ mittlere Expansion des Kumulus; IV= geringe Expansion des Kumulus, Abb. 1). Insgesamt gingen 936 Oozyten in den Versuch ein. Die Versuche wurde viermal wiederholt. 


\begin{tabular}{cc}
\hline Versuchsgruppe & $\begin{array}{c}\text { FKS-Konzentrationen } \\
(\%)\end{array}$ \\
\hline 1 & 0 \\
2 & 1 \\
3 & 5 \\
4 & 10 \\
\hline
\end{tabular}

Tabelle 2: Reifung follikulärer Oozyten des Schweines in unterschiedlichen Konzentrationen fetalen Kälberserums (Versuch 1)

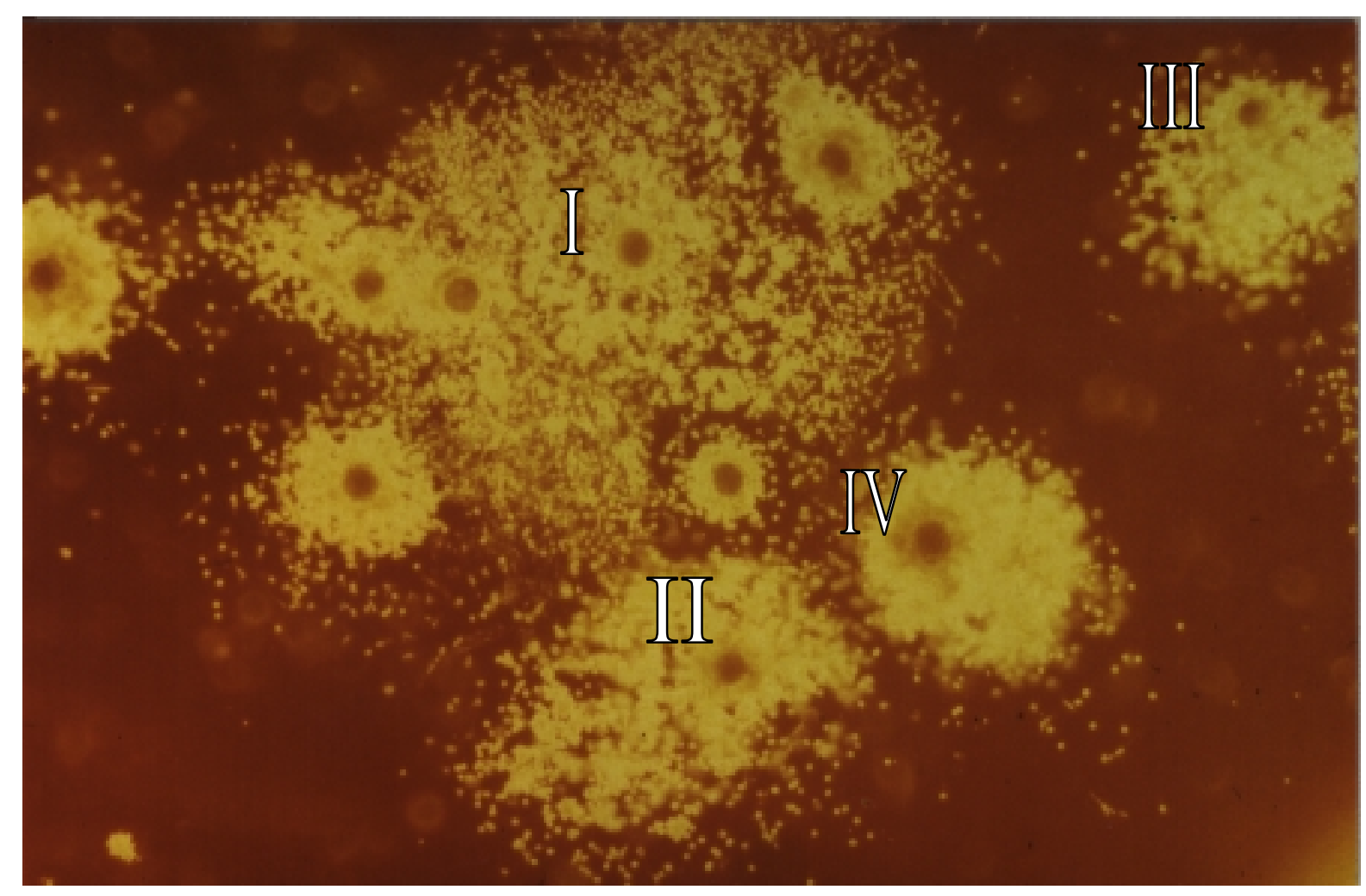

Abb.1: Ausgezeichnet (I), gut (II), mäßig (III) expandierte Kumulus- OozytenKomplexe, sowie eine Oozyte ohne Expansion des Kumulus oophorus (IV)

\subsubsection{Fixierung und Giemsa-Färbung gereifter Oozyten}

Die für die Färbung vorgesehenden Objektträger wurden für 15 Minuten in einem Färbekasten Hellendahl (GLW, Würzburg) mit einen Äther-Alkohol-Gemisch (1:1, Merck, Darmstadt) gereinigt. Danach wurden die Objektträger mit einem staub- und 
fusselfreien Tuch getrocknet und bis zur Verwendung in einer Objektträgerbox gelagert.

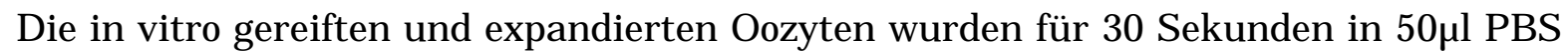
+2\%FKS + 80I.E Hyaluronidase-Drops (\# H-2251 aus Schafhoden, Sigma, Deisenhofen) inkubiert und die anhaftenden Kumulusmassen mit einer Mikropasteurpipette entfernt. Bei besonders fest anhaftenden Zellen, insbeondere der Corona radiata, wurden die Oozyten in $1 \mathrm{ml} 2 \%$ FKS-haltigem PBS-Medium mit 80I.E. Hyaluronidase für 3 Minuten im Reagenzglas geschüttelt (Mixomat, Hersel, Bonn).

Die Darstellung der Metaphase II geschah nach der Tarkowski-Methode (TARKOWSKI, 1966). Dazu wurden die Oozyten in $2 \mathrm{ml} 39^{\circ} \mathrm{C}$ warmer, hypotoner 1,1\%iger Natriumcitratlösung für 5 Minuten inkubiert. Danach wurden sie zentral auf dem Objektträger so plaziert, daß sie nur noch mit wenig hypotonem Natriumcitrat benetzt waren, allerdings ohne auszutrocknen.

Das Auftropfen von 50ul eiskalter Eisessig/Alkohollösung (1:3, v:v) auf die Oozyten brach das Zytoplasma der Oozyten auf und schwemmte die Chromosomen aus. Nach Trocknung auf der Wärmepatte wurden die Objektträger mit den Chromosomen für 56 Minuten in frischer 2\%iger Giemsalösung gefärbt, mit Aqua Dest gespült und erneut getrocknet. Anschließend wurden die Präparate mit einem Tropfen Eindeckmedium (DPX, Gurr, BDH, England) und Deckgläschen fixiert.

Die Chromosomenuntersuchung fand auf einem Phasenkontrastmikroskop (Axioskop Zeiss, Göttingen) bei 400facher Vergrößerung statt.

\subsection{Einfluß von Anti-hInhibin $\alpha$ Ziegenserum (Versuch 2)}

In einem zweiten Versuch sollte der Einfluß eines Ziegenserums, das Antikörper gegen Inhibin (Anti-hInhibin $\alpha$ Ziegenserum) enthielt, untersucht werden (Tabelle 3.).

In diesem Versuch wurden von 1872 mit Giemsa angefärbten Oozyten (Abb. 2) 1430 wiedergefunden und deren Chromosomenkonstellation beurteilt (Tabelle 9). Das entspricht einer Wiederfindungsrate von 76\%. Der Versuch wurde neunmal wiederholt.

Das verwendete „Anti-Inhibin“ wurde von immunisierten Ziegen gewonnen und lag somit als Bestandteil von Ziegenserum vor, welches nicht hitzeinaktiviert wurde, um so einer eventuellen Zerstörung der Antikörper vorzubeugen (Anti-INH). Dieses antikörperhaltige Serum wurde einem hitzeinaktivierten östrischen antikörperfreiem Ziegenserum (ZS) in den Konzentrationen von 0,1 und $1 \%$ zugesetzt, so daß die Proteinquelle im Medium in der Summe 10\% ergab. Als Kontrolle diente Ziegenserum 
ohne Anti-Inhibin (ZS ak) welches ebenfalls nicht hitzeinaktiviert und in analogen Konzentrationen zum antiinhibinhaltigen Ziegenserum eingesetzt wurde (1\%, 0,1\%). In weiteren vergleichenden Versuchsgruppen kamen porcine Follikelflüssigkeit (pFF) und FKS zu jeweils $10 \%$ zum Einsatz.

Zuerst wurde nach der Reifung der Oozyten die Ausprägung des expandierten Kumulus oophorus in einem Vier-Klassensystem ( $\mathrm{I}=\mathrm{sehr}$ gute Expansion des Kumulus; II= gute Expansion des Kumulus; III= mittlere Expansion des Kumulus; IV= schlechte Expansion des Kumulus) bewertet. Danach erfolgte die Bestimmung der Maturationsrate mittels Giemsa-Färbung.

Tabelle 3: In-vitro Reifung porciner Oozyten mit Anti-hInhibin- $\alpha$ Ziegenserum und hitzeinaktiviertem Ziegenserum als Proteinquelle (Versuch 2)

\begin{tabular}{cc}
\hline Versuchgruppe & Proteinquelle \\
\hline 1 & $10 \% \mathrm{pFF}$ \\
2 & $10 \% \mathrm{FKS}$ \\
3 & $10 \% \mathrm{ZS}$ \\
4 & $9 \% \mathrm{ZS}+\quad 1 \% \mathrm{ZS}$ Anti-INH \\
5 & $9,9 \% \mathrm{ZS}+0,1 \% \mathrm{ZS}$ Anti-INH \\
6 & $9 \% \mathrm{ZS}+\quad 1 \% \mathrm{ZS}$ ak \\
7 & $9,9 \% \mathrm{ZS}+0,1 \% \mathrm{ZS} \mathrm{ak}$ \\
\hline
\end{tabular}




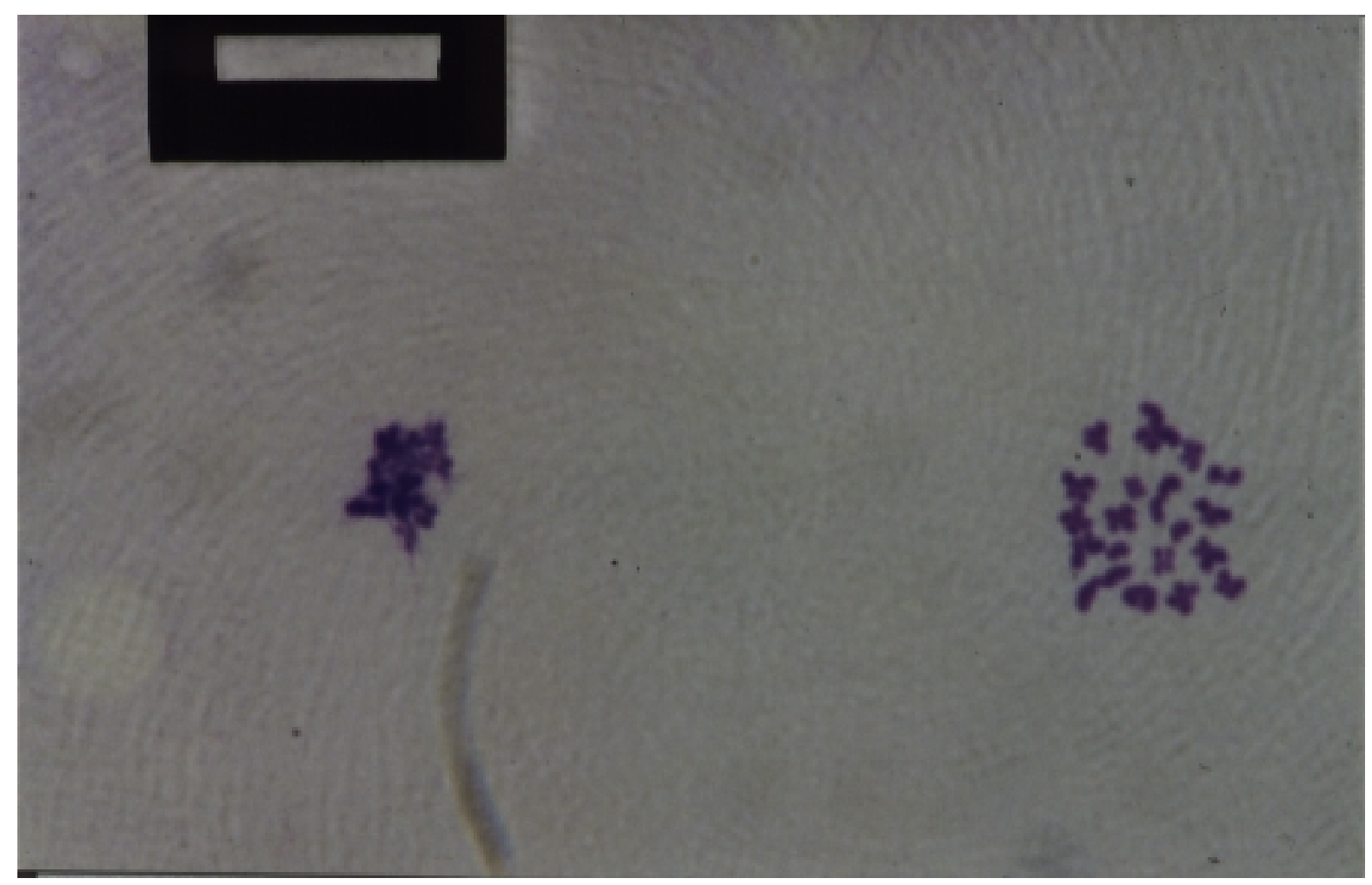

Abb. 2: Mit Giemsa angefärbte Oozyte in der Metaphase II; Links degenerierter Chromosomensatz, der als Polkörperchen ausgeschleußt wird, rechts intakter Chromosomensatz der Oozyte $($ Balken $=50 \mu \mathrm{m})$ 


\subsection{Einsatz porciner Follikelflüssigkeit als Basisproteinquelle für Anti hInhibin- $\alpha$ Ziegenserum (Versuch 3)}

Mittels der Lacmoid-Färbemethode war es im Gegensatz zur Giemsa-Färbung, wo die Oozyten während des Färbeprozesses leicht verloren gehen konnten, möglich, alle eingesetzten Oozyten auch wiederzufinden und zu beurteilen. Ferner konnte mittels dieser Färbung auch das Voranschreiten der Meiose beurteilt werden, da die einzelnen meiotischen Stadien exakt identifiziert werden konnten (Abb. 3 bis 8). Im Gegensatz zu Versuch 2 diente hier porcine Follikelflüssigkeit als Basisproteinquelle und nicht hitzeinaktiviertes Ziegenserum. Die Maturationsrate wurde mit Hilfe der Lacmoidfärbung ermittelt. Mit dieser Färbemethode können alle meiotischen Phasen erfaßt werden (Germinal vesicle; GV/ Germinal vesicle breakdown, GVBD/ Prometaphase I/ Metaphase I/ Anaphase I/ Telophase I/ Metaphase II).

Tabelle 4: In-vitro Reifung porciner Oozyten mit Anti-hInhibin- $\alpha$ Ziegenserum und porciner Follikelflüssigkeit als Proteinquelle (Versuch 3)

\begin{tabular}{|c|c|}
\hline Versuchsgruppe & Proteinquelle \\
\hline 1 & $10 \%$ porcine Follikelflüssigkeit \\
\hline 2 & $\begin{array}{c}5 \% \mathrm{pFF}+5 \% \text { anti }- \text { inhibinhaltiges } \\
\text { Ziegenserum }\end{array}$ \\
\hline 3 & $\begin{array}{c}9 \% \mathrm{pFF}+1 \% \text { anti }- \text { inhibinhaltiges } \\
\text { Ziegenserum }\end{array}$ \\
\hline 4 & $\begin{array}{c}9,9 \% \mathrm{pFF}+0,1 \% \text { anti - inhibinhaltiges } \\
\text { Ziegenserum }\end{array}$ \\
\hline 5 & $\begin{array}{c}5 \% \mathrm{pFF}+5 \% \text { nicht hitzeinaktiviertes } \\
\text { Ziegenserum }\end{array}$ \\
\hline 6 & $\begin{array}{c}9 \% \mathrm{pFF}+1 \% \text { nicht hitzeinaktiviertes } \\
\text { Ziegenserum }\end{array}$ \\
\hline 7 & $\begin{array}{c}9,9 \% \mathrm{pFF}+0,1 \% \text { nicht hitzeinaktiviertes } \\
\text { Ziegenserum }\end{array}$ \\
\hline
\end{tabular}


In Versuch 3 mit vier Wiederholungen wurde die nukleare Reifung von 483 Schweineoozyten nach Kultur in Maturationsmedien mit verschiedenen Serumanteilen bzw. pFF oder $10 \%$ reiner pFF (Tabelle 4) überprüft. Nach Ablauf der Reifungszeit wurden die expandierten Kumulus-Oozyten-Komplexe nach Entfernung der Kumulusmassen (vgl. Kap. 3.6.1) fixiert und mit Lacmoid gefärbt, um ihren meiotischen Status zu untersuchen.

\subsection{Fixierung und Färbung der Oozyten mit Lacmoid}

Nach der Maturation der Oozyten über einen Zeitraum von 46 Stunden, wurden die expandierten Kumulus-Oozyten-Komplexe für 30 Sekunden in 80 I.E. Hyaluronidase (Sigma, Deisenhofen) inkubiert und durch Auf- und Abpipettieren mit einer fein ausgezogenen Pasteurpipette von noch anhaftenden Kumuluszellen befreit. Danach wurden sie in einem 10 $\mu$ l Tropfen PBS-Medium ohne Serumzusatz zu maximal 20 Oozyten auf einem fettfreien Objektträger (Vgl. Kap. 3.6.1.) positioniert. Eine Fettmischung aus Vaseline und Paraffin (9:1 w/w) wurde mit einer 10ml Spritze und 21g Kanüle beiderseits des Tropfens aufgetragen, um das Deckgläschen über den Oozyten zu fixieren. Um einem Abschwemmen der Deckgläschen in der Fixierlösung vorzubeugen, wurden zwei Streifen $60^{\circ} \mathrm{C}$ warmes Vaseline/Paraffin-Gemisch (1:1 w/w) auf die Kanten des Deckgläschens mit einer großlumigen Pasteurpipette aufgetragen. Die Objektträger wurden anschließend 24 Stunden in Essigsäure - Alkohol (1:3) fixiert und mit 1\% (v/w) Essigsäure-Lacmoid (Sigma, Deisenhofen) gefärbt.

Die Beurteilung der meiotischen Phasen der angefärbten Oozyten erfolgte am frischen Präparat unter einem Phasenkontrasmikroskop (Zeiss Axioskop, Göttingen) bei 400facher Vergrößerung. 


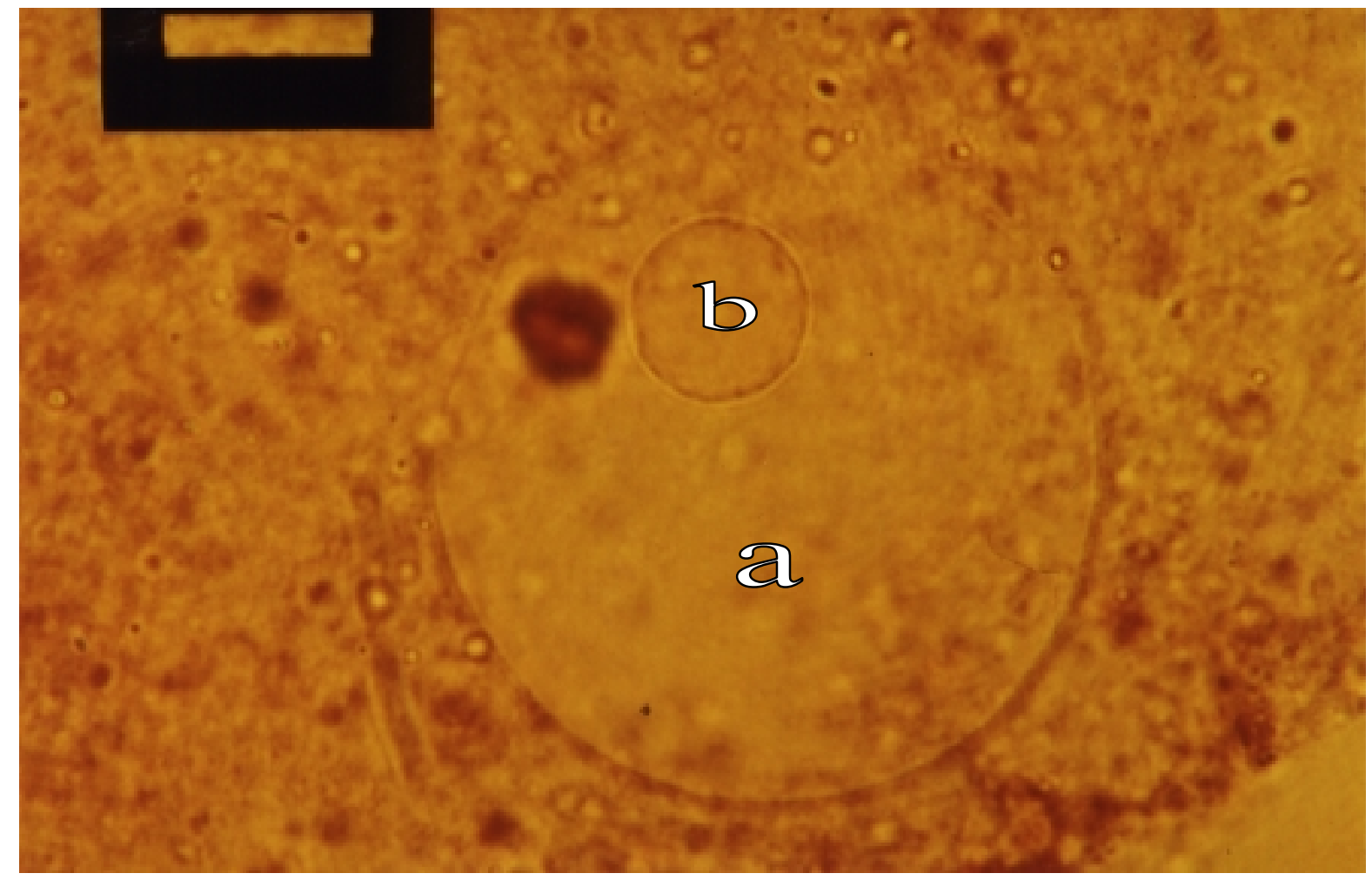

Abb. 3: Germinal vesicle, GV, Keimbläschenstadium. Deutlich sind der Nucleus (a) und Nucleolus (b) der Oozyte zu erkennen ( Balken $=50 \mu \mathrm{m})$.

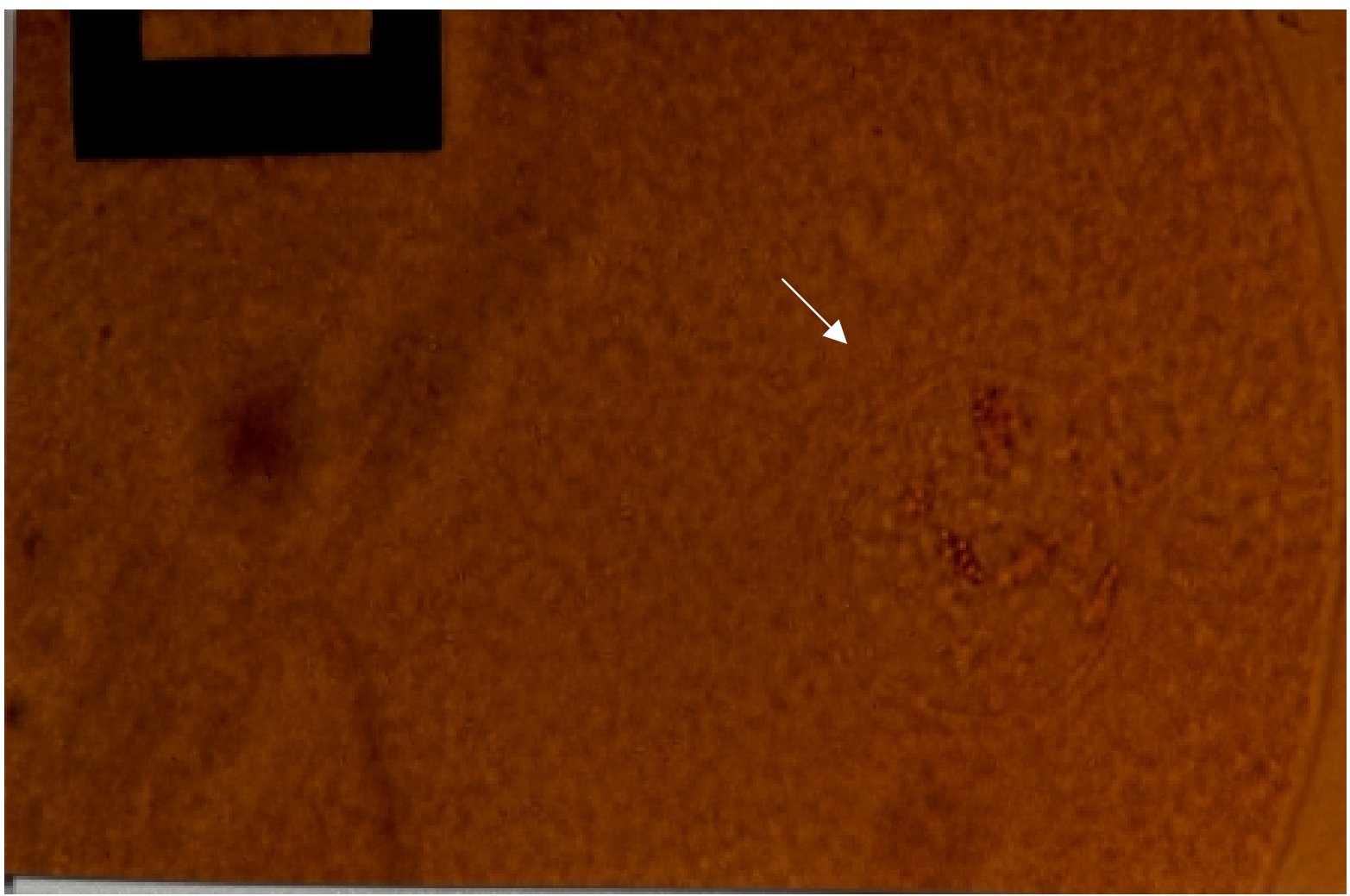

Abb. 4: Germinal vesicle breakdown, GVBD (Pfeile). Die Auflösung der Kernmembran hat begonnen. Die Meiose wurde wieder aufgenommen (Balken $=50 \mu \mathrm{m})$. 


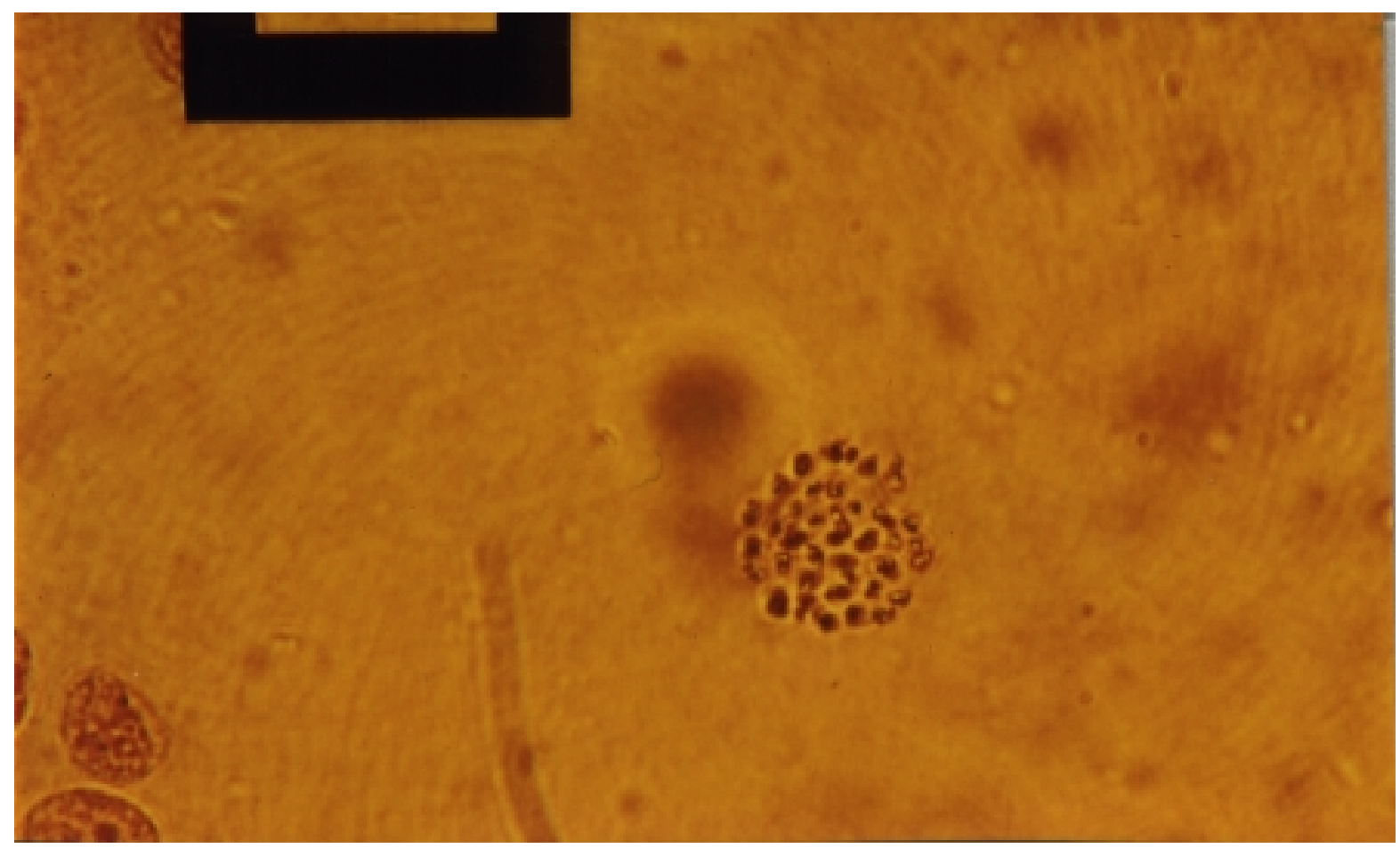

Abb 5: Prometaphase I. Die Chromosomen verdicken sich und kondensieren $($ Balken $=50 \mu \mathrm{m})$

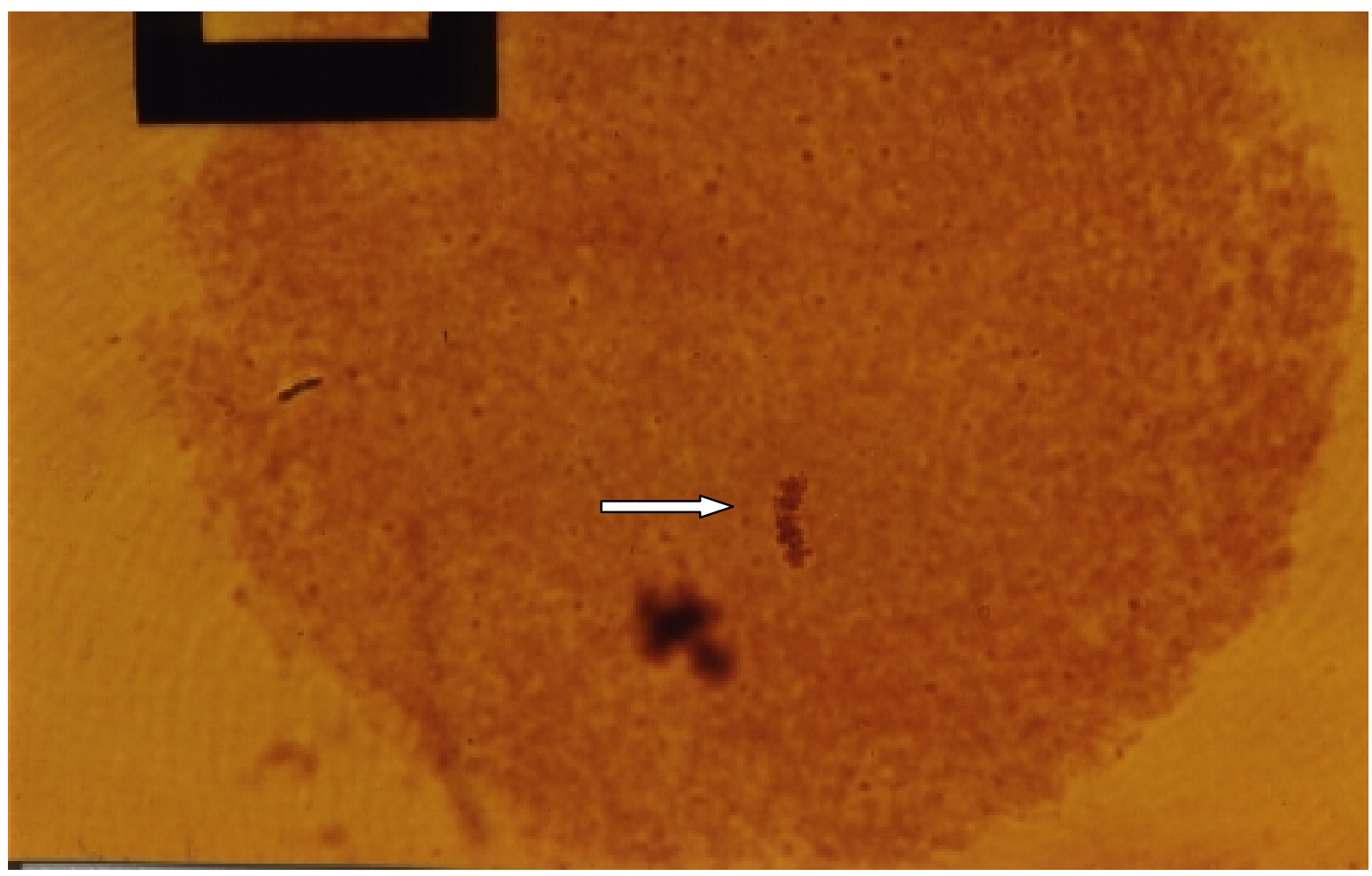

Abb. 6: Metaphase I: Die Chromosomen ordnen sich in der Äquatorialebene der Oozyte an $($ Balken $=50 \mu \mathrm{m})$ 


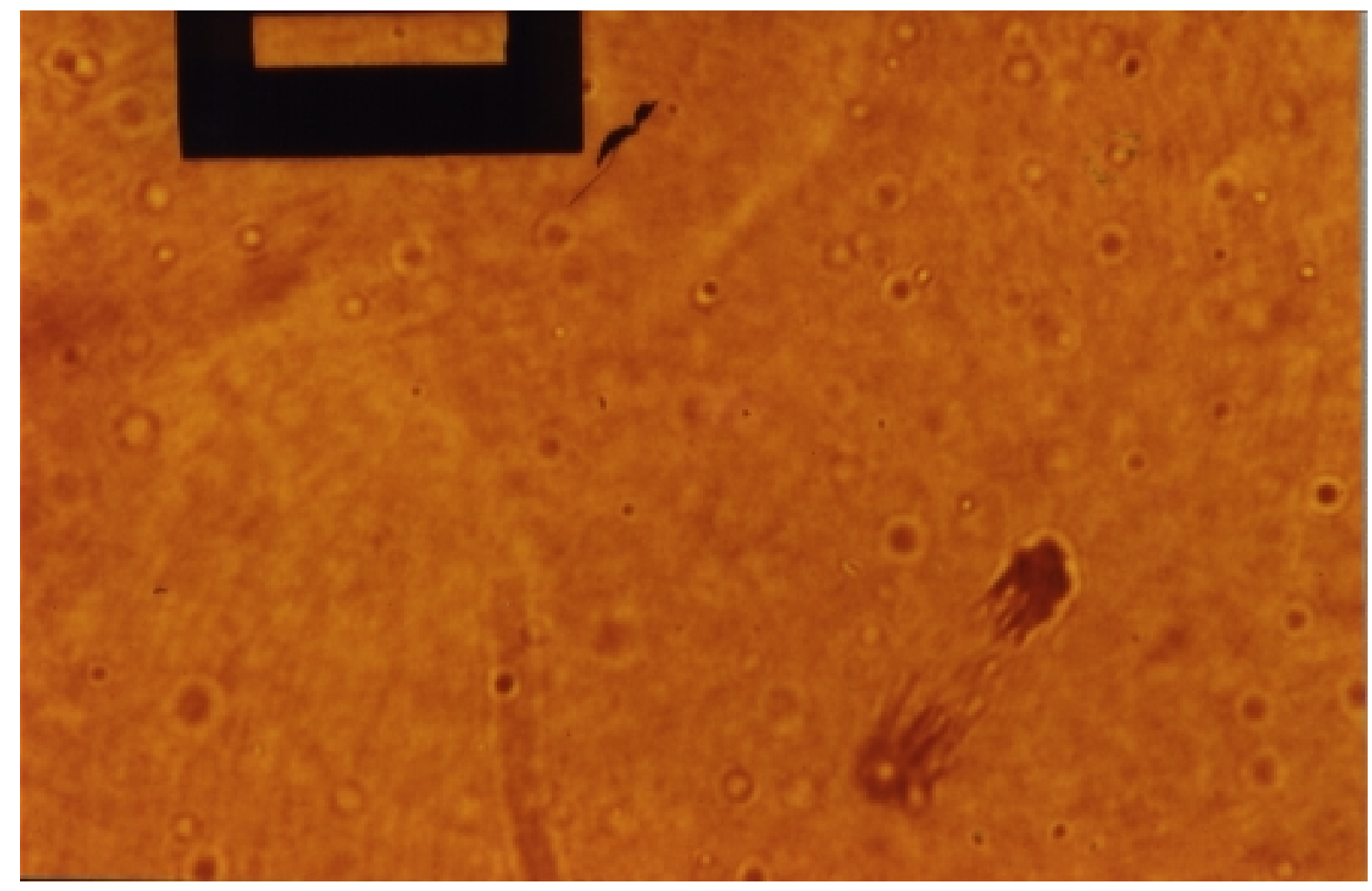

Abb. 7: Anaphase I. Der Spindelapparat ist ausgebildet und zieht die homologen Chromosomen zu den Polen (Balken $=50 \mu \mathrm{m})$

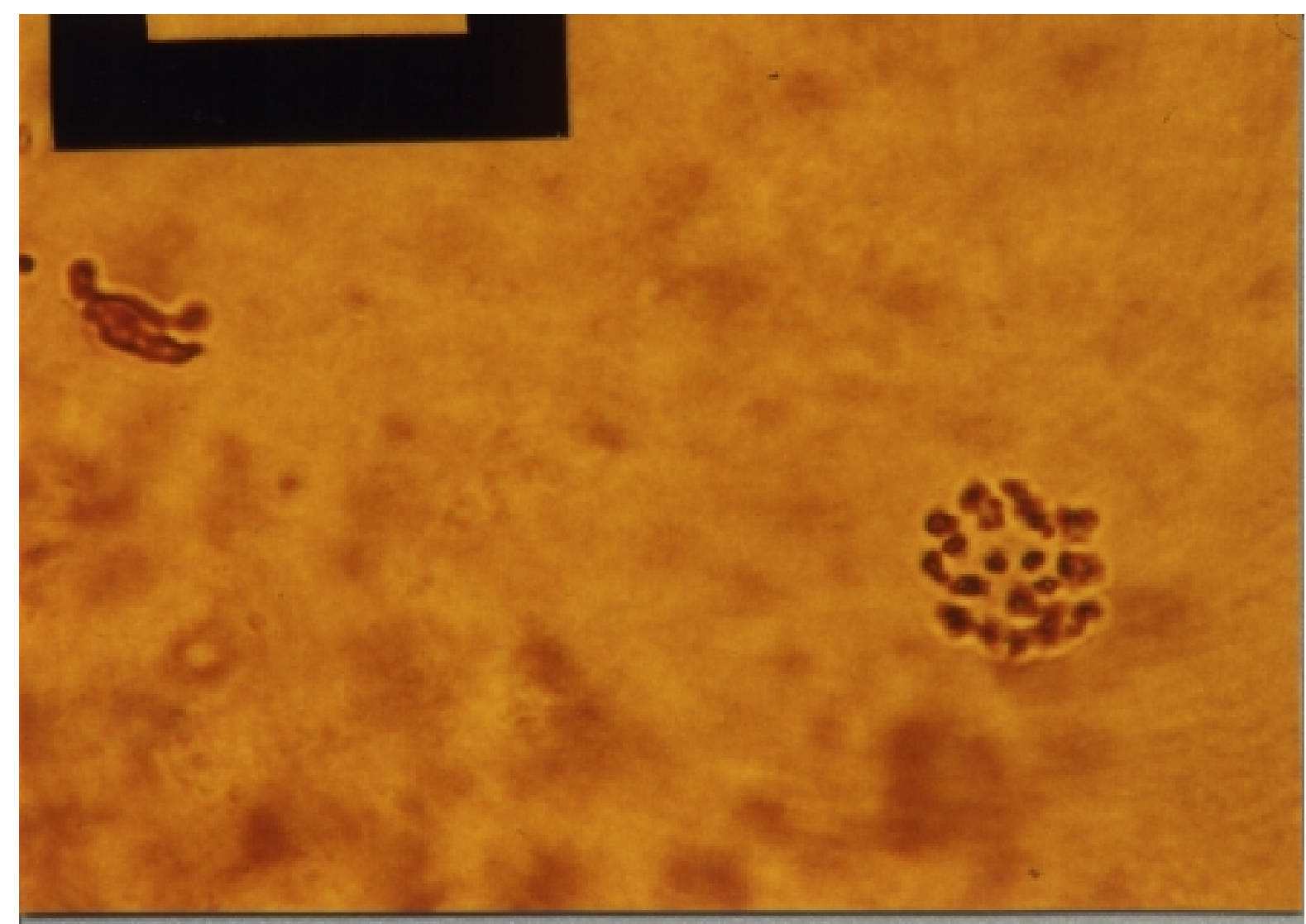

Abb. 8: Metaphase II. Der Chromosomensatz hat sich in ein Polkörperchen und einen homologen Chromosomensatz aufgeteit. Die Oozyte ist gereift (Balken $=50 \mu \mathrm{m})$ 


\subsection{Herstellung von Feederlayern}

\subsubsection{Gewinnung der Eileiterzellen für die Feederlayerkultur}

Die Eileiter wurden von peripuberalen Jungsauen auf dem Schlachthof gewonnen. Beide Tuben wurden cranial am Ostium abdominale tubae uterinae und distal des Isthmus tubae uterinae am Uterushorneingang mit einem Kunststoffaden (Synthacord

EP 7, Beyverts, Berlin) fest verschlossen, bevor sie mit einer Schere vom Uterus abgetrennt wurden. Sie wurden danach sofort in $1000 \mathrm{ml}$ eiskalter $0,9 \%$ iger NaClLösung mit 10ml Penicillin/Streptomycin Lösung (= 200I.E./ml Penicillin; 200 $\mathrm{\mu g} / \mathrm{ml}$ Streptomycin, Gibco BRL, Eggenstein) gesammelt und ins Labor transportiert. Alle weiteren Arbeitsschritte zur Präparation der Eileiter erfolgten unter sterilen Bedingungen mittels der Reinraumwerkbank (Steag, Rettberg, Göttingen). Nach zweimaligem Waschen der Organe in eiskalter 0,9\%iger NaCl-Lösung mit 10ml Penicillin/Streptomycin Lösung (=200I.E./ml Penicillin; 200 $\mathrm{gg} / \mathrm{ml}$ Streptomycin, Gibco BRL, Eggenstein) wurde jeweils ein Eileiter für 15 Sekunden in 70\%igem Alkohol gespült. Danach erfolgte erneut eine sorgfältige Spülung in eiskalter physiologischer Kochsalzlösung ohne Antibiotika. Jetzt wurde am abgebundenen Isthmus tubae uterinae das Lumen der Ampulla tubae uterinae eröffnet. Diese Öffnung wurde über ein offenes Zentrifugenröhrchen geführt, um dann auch den oberen Abbindefaden am Ostium abdominale tubae uterinae zu entfernen. Nun war es möglich, mit einer stumpfen Kanüle 10ml Eileiterspülmedium (TCM199 + $70 \mu \mathrm{g} / \mathrm{ml}$ Kanamycin $+20 \%$ FKS) durch den Eileiter zu pressen. Das im Zentrifugenröhrchen aufgefangene Medium mit Eileiterzellen wurde mit Deckel bis zur weiteren Aufbereitung auf Eis gelagert.

Waren alle Eileiter gespült, wurde eine Zentrifugation der im Medium angereicherten Oviduktzellen bei 1500 x g für 10min durchgeführt. Der Überstand des Mediums wurde verworfen und durch $500 \mu$ f frisches Eileiterspülmedium ersetzt. Das Sediment wurde resuspendiert und in $10 \mathrm{ml} 39^{\circ} \mathrm{C}$ warmes und bei $5 \% \quad \mathrm{CO}_{2}$ äquilibriertes Eileitermedium in $100 \mathrm{~mm}$ Zellkulturschalen ausgesäht. Die Eileiterepithelzellkultur war nach einer Woche konfluent und wurde nach Trypsinisierung noch zweimal neu passagiert. Nach der letzten Pasage wurden die Eileiterzellen mit PBS (ohne Calciumund Antibiotika) gewaschen, um das FKS aus dem Eileitermedium zu entfernen. Danach wurden die konfluenten Eileiterfeeder mit 0,5\% Trypsin-EDTA für 5 Minuten auf der Wärmeplatte inkubiert. Die nach der Inkubationszeit abgelösten Eileiterzellen wurden nun mit einer Pasteurpipette aufgenommen und in 10ml Eileitermedium mit 
FKS im Zentrifugenröhrchen überführt, um das Enzym Trypsin zu inaktivieren. Nach 10 minütiger Zentrifugation bei $1500 \mathrm{x}$ g wurde das Eileitersediment mit Einfriermedium (DMEM + 10\%FKS + 10\%DMSO + 1ml Penicillin-StreptomycinLösung $+0,5 \mathrm{ml}$ 20\%ige Glucoselösung) aufgenommen, portioniert und im Kryoröhrchen (Sarstedt, Nümbrecht) bei $-196^{\circ} \mathrm{C}$ im flüssigen Stickstoff bis zur Verwendung tiefgefroren.

\subsubsection{Herstellung der Eileiter - Feederlayer}

Die tiefgefrorenen Eileiterzellen (vgl Kap. 3.9.1.) wurden bei $37^{\circ} \mathrm{C}$ im Wasserbad aufgetaut und in 10ml Zellwaschmedium (TCM199 + 70 $\mu \mathrm{g} / \mathrm{ml}$ Kanamycin $+20 \%$ FKS) überführt. Nach einer Zentrifugation bei 1500 x g für 10 Minuten wurde der Überstand verworfen, und das Zellsediment erneut in 500ul Zellwaschmedium aufgenommen und resuspendiert. Diese Eileiterzellsuspension wurde nun zu 10x106 Zellen/ml in einer Vierlochschale in 500 $\mu$ l Eileitermedium ausgesäht und bis zum Gebrauch für drei Tage im Brutschrank bei $39^{\circ} \mathrm{C}$ und $5 \% \mathrm{CO}_{2}$ inkubiert. Nach Erhalt des konfluenten Monolayers wurde das Medium abgenommen, ohne die Zellage zu verletzten und mit dem bei $39^{\circ} \mathrm{C}$ und $5 \% \mathrm{CO}_{2}$ äquilibrierten Medium des jeweiligen Versuchansatzes auf der $37^{\circ} \mathrm{C}$ warmen Wärmeplatte stehend für eine Minute überschichtet. Nach Entfernung dieses Mediums wurde erneut frisches Medium des einzelnen Versuchsansatztes ersetzt, um ein definiertes Mediummilieu innerhalb eines Wells zu gewährleisten.

\subsubsection{Herstellung der Buffalo-Rat-Liver-Feederlayer}

Die BRL-Zellinie (Buffalo-ㅌed-Liver) aus dem Institut für Institut für Pflanzengenetik und Kulturpflanzenforschung, Gatersleben lag tiefgefroren im flüssigen Stickstoff vor. Sie wurde wie tiefgefrorene Eileiterzellen aufbereitet und ausgesäht. Die Zelldichte in der Vierlochschale betrug 1×106 BRL-Zellen/ml.

\subsection{Einsatz von Eileiter- und Buffalo-Rat-Liver-Feederlayern (Versuch 4)}

Aus den vorhergehenden Untersuchungen ergab sich die Frage, ob der Zusatz von nicht hitzeinaktiviertem Ziegenserum oder anti - inhibinhaltigem Ziegenserum einen Einfluß auf die nukleare und zytoplasmatische In-vitro-Maturation der Oozyten hat, 
wenn noch zusätzlich verschiedene Feederlayer während der 46 stündigen Reifungsphase der Oozyten eingesetzt werden.

Feeder-(Ernährungs-)-Zellen synthetisieren in Zellkultursystemen ein weites Spektrum an zellspezifischen Faktoren und konditionieren auf diese Weise das Medium für andere Zellen. In den vorliegenden Versuchen wurden folgende Zelltypen als Feederlayer eingesetzt:

1. Porcine Eileiterzellen (pEIL) zur Simulation der In-vivo-Bedingungen (WHITE et al. 1989).

2. Buffalo-Rat-Liver-Zellen (BRL) als Produzenten zahlreicher embryonaler Wachstumsfaktoren (SMITH \& HOOPER, 1987).

Es wurden 12 Versuchsgruppen aufgestellt ( Tabelle 5).

Tabelle 5: In-vitro Reifung von Schweineoozyten auf Feederlayern (Versuch 4)

\begin{tabular}{ccc}
\hline Versuchsgruppe & Proteinquelle & Feederlayer \\
& & \\
\hline 1 & $10 \% \mathrm{pFF}$ & ohne Feederlayer \\
3 & $10 \% \mathrm{pFF}$ & Eileiterfeederlayer \\
\hline 4 & $10 \% \mathrm{pFF}$ & BRL-Feederlayer \\
5 & $9 \% \mathrm{pFF}+1 \%$ Anti-INH & ohne Feederlayer \\
6 & $9 \% \mathrm{pFF}+1 \%$ Anti-INH & Eileiterfeederlayer \\
\hline 7 & $9 \% \mathrm{pFF}+1 \%$ Anti-INH & BRL-Feederlayer \\
\hline 8 & $9 \% \mathrm{pFF}+1 \% \mathrm{ZS}$ ak & ohne Feederlayer \\
9 & $9 \% \mathrm{pFF}+1 \% \mathrm{ZS}$ ak & Eileiterfeederlayer \\
\hline 10 & $9 \% \mathrm{pFF}+1 \% \mathrm{ZS}$ ak & BRL-Feederlayer \\
\hline 11 & ohne Serum & ohne Feederlayer \\
12 & ohne Serum & Eileiterfeederlayer \\
\hline
\end{tabular}

In Versuch 4 wurde mit 1146 Oozyten in vier Wiederholungen der Einfluß von Feederlayern auf die nukleare Reifung untersucht. Neben dem Einfluß einer Serumkomponente sollte zusätzlich der Einfluß von Feederlayern bei der In-vitroReifung von Schweineoozyten erörtert werden. Beide Feederlayer (Eileiter und BRL) wurden mit Anti-Inhibin-/Follikelflüssigkeitsmischungen (v:v, 1:9) sowie nicht 
hitzeinaktiviertem Ziegenserum/Follikelflüssigkeit (v:v, 1:9) kombiniert. Weiterhin wurde der Einfluß von Kontrollgruppen ohne Feederlayer mit Proteinquelle und mit Feederlayer ohne Proteinquelle getestet. VANSTEENBRUGGE et al. (1994) zeigen, daß sowohl BRL- als auch Eileiterzellen den pH-Wert der Kulturmedien, sowie die Sauerstoff-Kohlendioxid-Verhältnis oder Ionen-, Vitamin- und Lipidkonzentrationen konstant halten können.

Erneut wurden die meiotischen Phasen der Oozyten nach 46 stündiger Maturationsphase mit Hilfe der Lacmoidfärbung beurteilt.

\subsection{Eigene Untersuchungen zur In-vitro-Fertilisation in vitro gereifter Oozyten.}

In anschließenden Versuchen wurde nun auch die zytoplasmatische Reife der in vitro gereiften Oozyten untersucht.

Die in vitro befruchteten und kultivierten Oozyten wurden nach 2 Tagen Kultur auf dreierlei Weise klassifiziert. Die erhaltenen Embryonen wurden visuell morphologisch beurteilt, mit einer FDA - Färbung auf die Integrität ihres Zytoplasmas untersucht sowie mittels Hoechst A 33342-Fluoreszenzfärbung mitotisch intakte Kerne nachgewiesen. Diese drei Klassifizierungsmöglichkeiten wurden bei jeder Versuchsgruppe durchgeführt werden, so daß jeder einzelne Embryo der einzelnen Versuchsgruppen gleichzeitig Aussagen über drei Kriterien liefern konnte. Im letzten Versuch wurden die erhaltenen Embryonen nicht durch Färbung beurteilt, sondern auf synchronisierte Empfängersauen transferiert.

\subsubsection{Spermagewinnung}

Das Sperma für die in-vitro-Fertilisation wurde mit der Handdruckmethode von einem Minischweineber gewonnen (PAUFLER et al., 1974). Die spermareiche Fraktion (50$150 \mathrm{ml}$ ) des Ejakulates wurde in einem sterilen, auf $35^{\circ} \mathrm{C}$ vorgewärmten und mit 2 Lagen Gaze abgedeckten Glas aufgefangen, tropfenweise mit vorgewärmten $70 \mu \mathrm{g} / \mathrm{ml}$ Kanamycin (Sigma, Deisenhofen) versetzt. Danach erfolgte eine Portionierung des Ejakulates in sterile $10 \mathrm{ml}$ Reagenzgläser, die mit Alufolie und Parafilm luftdicht verschlossen und im Reagenzglasständer für 12-16 Stunden in einer Klimabox (Experta, Tropicool P-30 -G) bei $16^{\circ} \mathrm{C}$ für eine Präkapazitation gelagert wurden. 


\subsubsection{Spermaaufbereitung}

Nach der Präkapazitation wurden die Reagenzgläser mit dem Ejakulat sowie das Spermawasch-und Kapazitationsmedium (Vgl. Kap. 3.2.3. und 3.2.4.) langsam auf 20$25^{\circ} \mathrm{C}$ erwärmt.

Das Ejakulat wies nach der 12-16 stündigen Präkapazitaionsphase in den Reagenzgläsern zwei Spermafraktionen auf. Der plasmareiche Überstand wurde mit einer sterilen Pasteurpipette abgenommen und verworfen. Das spermareiche Sediment wurde nun behutsam mit dem erwärmten Spermawaschmedium versetzt bevor die Suspension bei $200 \mathrm{x}$ g für 8 Minuten zentrifugiert wurde.

Nach der Zentrifugation bildeten sich aus der Suspension erneut zwei Phasen. Das Sediment enthielt tote, immotile Spermatozoen. Im Überstand befanden sich die vitalen, motilen Spermatozoen, die abgenommen und erneut bei $600 \mathrm{x} \mathrm{g}$ für 10 Minuten zentrifugiert wurden. Während dieser Zentrifugation wurde der $\mathrm{pH}-$ Wert des erwärmten Kapazitiermediums überprüft und mit $1 \mathrm{M} \mathrm{NaOH}$ oder HCL auf pH 7,8 eingestellt.

Nach der zweiten Zentrifugation wurde das Spermapellet erneut mit 10ml Spermawaschmedium resuspendiert und bei 600 x g für 10 Minuten zentrifugiert, der Überstand verworfen und nun mit Kapazitiermedium überschichtet.

Nach der Resuspendierung des Pellets im Kapazitiermedium wurden die Spermatozoen im Zentrifugenröhrchen für 60 Minuten bei $39^{\circ} \mathrm{C}$ inkubiert (CHENG et al., 1986).

Nach Ablauf der Kapazitationszeit wurde das Sperma auf Motilität und Dichte überprüft, um festzulegen, welches Volumen notwendig war, um in $400 \mu \mathrm{l}$ Befruchtungsmedium eine Spermiendichte von $1 \times 10^{6}$ Spermien $/ \mathrm{ml}$ zu erreichen.

\subsubsection{Befruchtung der Oozyten}

Nach 46-stündiger Maturation wurden die expandierten und muzifizierten KumulusOozyten-Komplexe (KOK`s) dreimal in 70pl Befruchtungsmedium (Vgl. Kap. 3.2.5.)

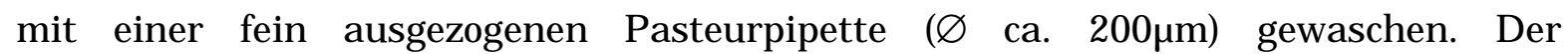
Waschvorgang dieser gereiften Kumulus-Oozyten-Komplexe fand auf einer Wärmeplatte (Minitüb, Tiefenbach) unter der Stereolupe (M8,Wild, Herrbrugg, Schweiz) bei 12facher Vergrößerung statt. Nach dem Waschen wurden jeweils 20 KOK's in 4-Loch Schalen (Nunc, Nunclon GLW) in 400ul äquilibriertes und mineralölüberschichtetes Befruchtungsmedium übertragen. 


\subsubsection{Die frühe Embryokultur}

Nach einer Inkubationszeit der Oozyten und Spermatozoen von 6 Stunden im

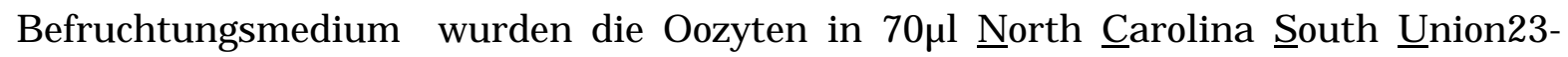
Medium (NCSU23, vgl. Kap. 3.2.6.1.) gewaschen und durch Auf- und Abpipettieren mit einer fein ausgezogenen Pasteurpipette $(\varnothing 150 \mu \mathrm{m})$ von anhaftenden Spermatozoen befreit. Auf diese Weise sollte die Möglichkeit der Polyspermie reduziert werden. Nach dreimaligem Waschen wurden die Oozyten in NCSU23-Medium mit Mineralöl mit oder ohne Feederlayer im Brutschrank bei $5 \% \mathrm{CO}_{2}, 39^{\circ} \mathrm{C}$ und $100 \%$ Luftfeuchte kultiviert. Dreißig Stunden nach der In-vitro-Befruchtung erfolgte ein Mediumwechsel (TROUNSON et al., 1994).

\subsection{Untersuchung der zytoplasmatischen Reife mit Anti- hInhibin- $\alpha$ Ziegenserum gereifter Oozyten durch in-vitro-Fertilisation (Versuch 5)}

In Versuch 5 wurde die zytoplasmatische Reife der Schweineoozyten überprüft, die mit Anti-Inhibin und porciner Follikelflüssigkeit in unterschiedlichen Konzentrationen in vitro gereift wurden. Dazu wurden die Oozyten wie in Versuch 3 (Vgl Kap. 3.8.) in sieben Versuchsansätzen gereift und anschließend befruchtet. Nach der In-vitroMaturation wurden die Ootyten in vitro befruchtet und kultiviert. Dreissig sowie 54 Stunden nach der Befruchtung wurde die Entwicklungs- bzw. Teilungsrate der in unterschiedlich supplementierten Maturationsmedien gereiften Oozyten ermittelt.

Es wurden 979 Oozyten bezüglich ihrer Entwicklungsfähigkeit nach IVF in vier Wiederholungen beurteilt.

\subsection{Untersuchung der zytoplasmatischen Reife auf Feederlayern gereiften Oozyten durch in-vitro-Fertilisation (Versuch 6)}

Im 6. Versuch wurden Oozyten in den gleichen Versuchsgruppen wie im vierten Versuch (Vgl. Kap. 3.10.) gereift und anschließend, anstatt gefärbt $\mathrm{zu}$ werden, befruchtet. Die Analyse der fertilisierten Oozyten erfolgte morphologisch nach 2 Kultivierungstagen in vitro gemäß Versuch 5 (Vgl. Kap. 3.12.). Es wurden 2317 Oozyten in 8 Wiederholungen nach der Reifung in-vitro fertilisiert und die Teilungrate bestimmt. 


\subsection{Untersuchung von Maturation und Kultur auf Feederlayern in-vitro gereifter und fertilisierter Oozyten (Versuch 7)}

Als Beurteilungskriterium für die Effektivität des Maturationssystems wurde in Versuch 6 die Teilungsaktivität der Oozyten nach In-vitro-Fertilisation herangezogen (Tabelle 14). Auch in Versuch 7 wurde die Teilungsrate bestimmt (Tabelle 15), die Versuchsanordnung entsprch der von Versuch 6. Es wurden nun zusätzlich Vitalitätskriterien bezüglich des Zytoplasmas (Tabelle 16, Abb. 10, 11 und 12) und des Kernmaterials (Tabelle 17) erhoben (FDA- und Hoechst-Fluoreszenzfärbungen). Dafür wurden in-vitro-gereifte und befruchtete Oozyten in NCSU-23 bei $39^{\circ} \mathrm{C}$ und $5 \% \mathrm{CO}_{2}$ und nach 30 und $54 \mathrm{~h}$ licht- und fluoreszenzmikroskopisch beurteilt. Dieser Versuchsansatz (Versuch 7) unterschied sich somit von anderen Untersuchungen, die Befruchtungsraten der in-vitro-maturierten Oozyten bereits 18 Stunden nach der Befruchtung nur durch Anfärbung des männlichen und weiblichen Vorkernes erhoben (NAITO et al., 1990; FUNAHASHI et al., 1993).

In Versuch 7 wurden 1371 Oozyten auf ihre Morphologie (=Teilungsrate), Intaktheit des Zytoplasmas (=Vitalität lebend/tot) sowie Intaktheit des Chromosomenmaterials (= Zellkernzahl) untersucht .

\subsubsection{Beurteilung der frühen Embryonalstadien}

Der Erfolg einer gelungen sowohl nuklearen als auch zytoplasmatischen Reifung der Oozyten, wurde nicht nur an den Oozyten, sondern auch an den physiologisch intakten Embryonen nach der Befruchtung bestimmt. Dazu wurden drei unterschiedliche Beurteilungskriterien herangezogen. Die Embryonen mußten morphologisch intakt sein. eine vitale Zytoplasmaaktivität aufweisen und als auch eine der Morphologie entsprechende Anzahl von Kernen zeigen.

\subsubsection{Morphologische Beurteilung}

Zwei Tage nach der Befruchtung wurden die Embryonen auf ihren Entwicklungsstatus hin untersucht und die Anzahl der Blastomeren wurde bestimmt. Als morphologisch intakte Embryonen wurden nur solche bezeichnet, die neben einer Anzahl gleichmäßig geformter Blastomeren auch ein intaktes Zytoplasma ohne stark aufgehellte Regionen in der Peripherie aufwiesen. 


\subsubsection{Kombinierte FDA- Hoechst-Färbung zur Bestimmung der Zytoplasmaaktivität}

Die FDA (3`6 - Fluorescin Diacetate, Sigma, Deisenhofen ) - Färbung ist eine Methode, zur Unterscheidung von toten und lebenden Embryonen. Lebende Embryonen zeigen ein hell grün leuchtendes Signal (Abb. 9). Die zu untersuchenden Embryonen wurden dreimal in $39^{\circ} \mathrm{C}$ warmen PBS gewaschen und dann in FDA-haltige PBS-Lösung überführt. Dazu wurde eine FDA-Stammlösung von 5mg FDA/ml Aceton (Merck, Darmstadt) in einer Konzentration von $2 \mu \mathrm{l} / 2 \mathrm{ml}$ PBS verdünnt (DIDION et al., 1990).

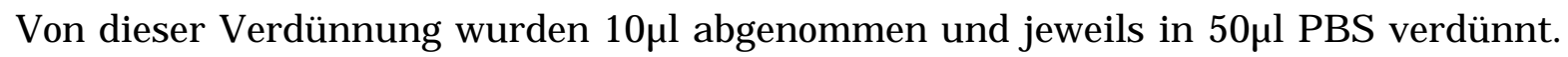
Die Embryonen verblieben jeweils für 1,5 Minuten bei $39^{\circ} \mathrm{C}$ auf der Wärmeplatte in der FDA-Lösung und wurden anschließend dreimal in PBS gewaschen.

Danach erfolgte die zweite Inkubation der Embryonen im Hoechst-Farbstoff. A33342 (Sigma, Deisenhofen), um mitotisch aktive Kerne sichtbar zu machen (Abb. 10, 11).

Eine Stammlösung von 1mg Hoechst A33342/ml Aqua dest (PURSEL et al., 1985) wurde zu je 10 $\mu \mathrm{l} / 50 \mu \mathrm{l}$ PBS verdünnt. Die Inkubationszeit im Hoechst-Farbstoff betrug 2 Minuten bei $39^{\circ} \mathrm{C}$ auf der Wärmeplatte.

Dann wurden die Embryonen auf einen Objektträger, auf den zuvor zwei Vaseline/Paraffin (w/w 1:9) Streifen aufgetragen wurden, in die Mitte positioniert und mit einem Deckgläschen abgedeckt, so daß die Zellen nur leicht gequetscht wurden.

Die FDA- Untersuchung fand mit einem Axioskop (Zeiss, Göttingen) Filtersatz 09 (Zeiss, Göttingen) bei einer Anregung von 450-490nm (BP Erregerfilter) und einer Emission von 520nm (Sperrfilter LP 520, Interferenzfilter FT 510) statt.

Die Beurteilung der Hoechst-Färbung erfolgte ebenfalls auf dem Fluoreszenzmikroskop (Axioskop, Zeiss, Göttingen) mit dem Filtersatz 02 (Zeiss, Göttingen) bei einer Anregung von 365nm (Erregerfilter G 365) und einer Emission von 420nm (Interferenzfilter FT 395, Sperrfilter LP 420). 
Abb. 9: Mit FDA angefärbte Oozyte. Die hellgrüne Fluoreszenzreaktion weist auf ein enzymatisch aktives Zytoplasma einer vitalen Oozyte hin

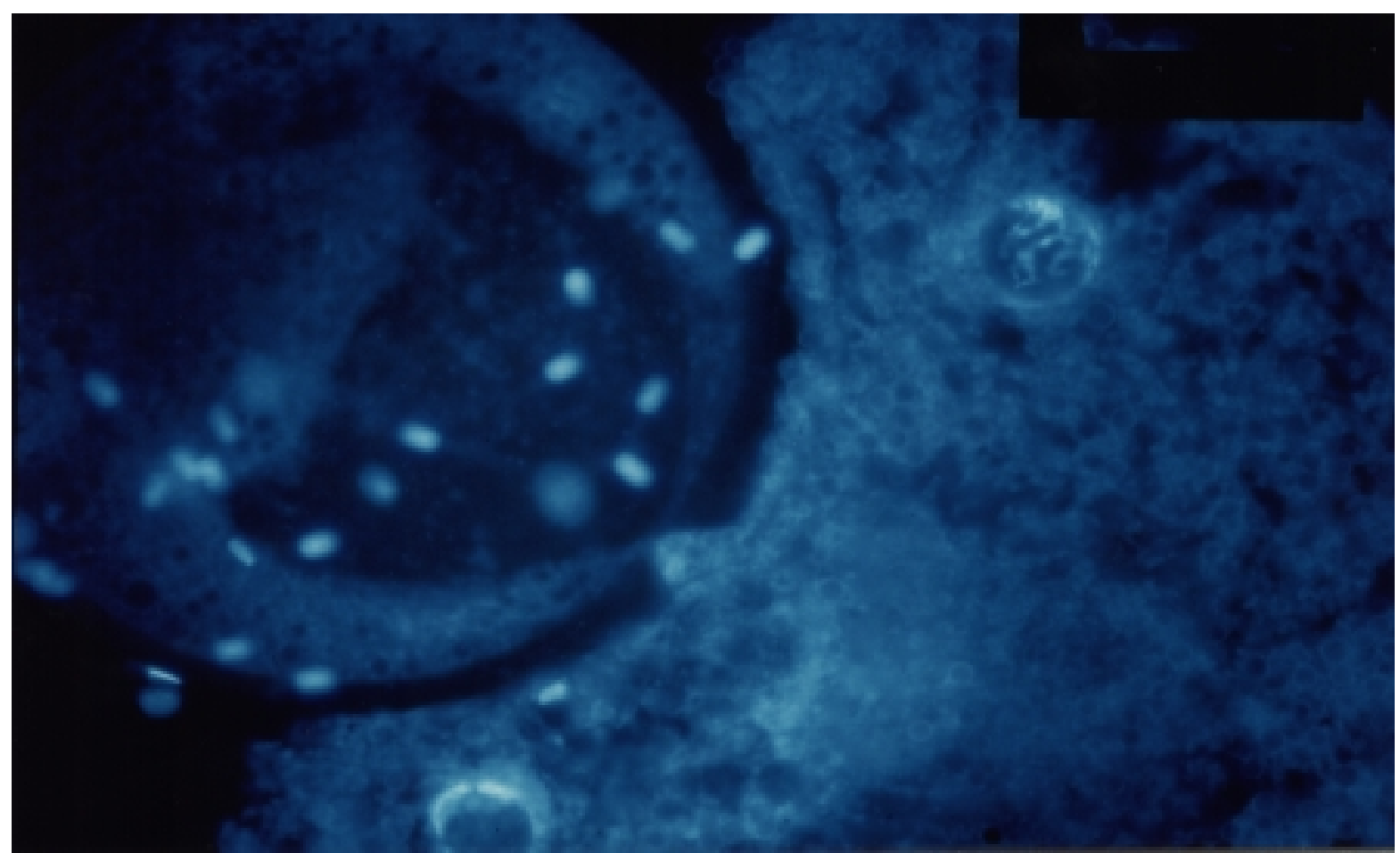

Abb. 10: Mit Hoechst A 3342 angefärbte Zygote. Das Zytoplasma mit Zellkernen (Pfeile) ist bei der Präparation ausgelaufen. Deutlich zu erkennen sind anheftende Spermatozoen an der Zona pellucida (kleine Pfeile) (Balken $=50 \mu \mathrm{m})$. 


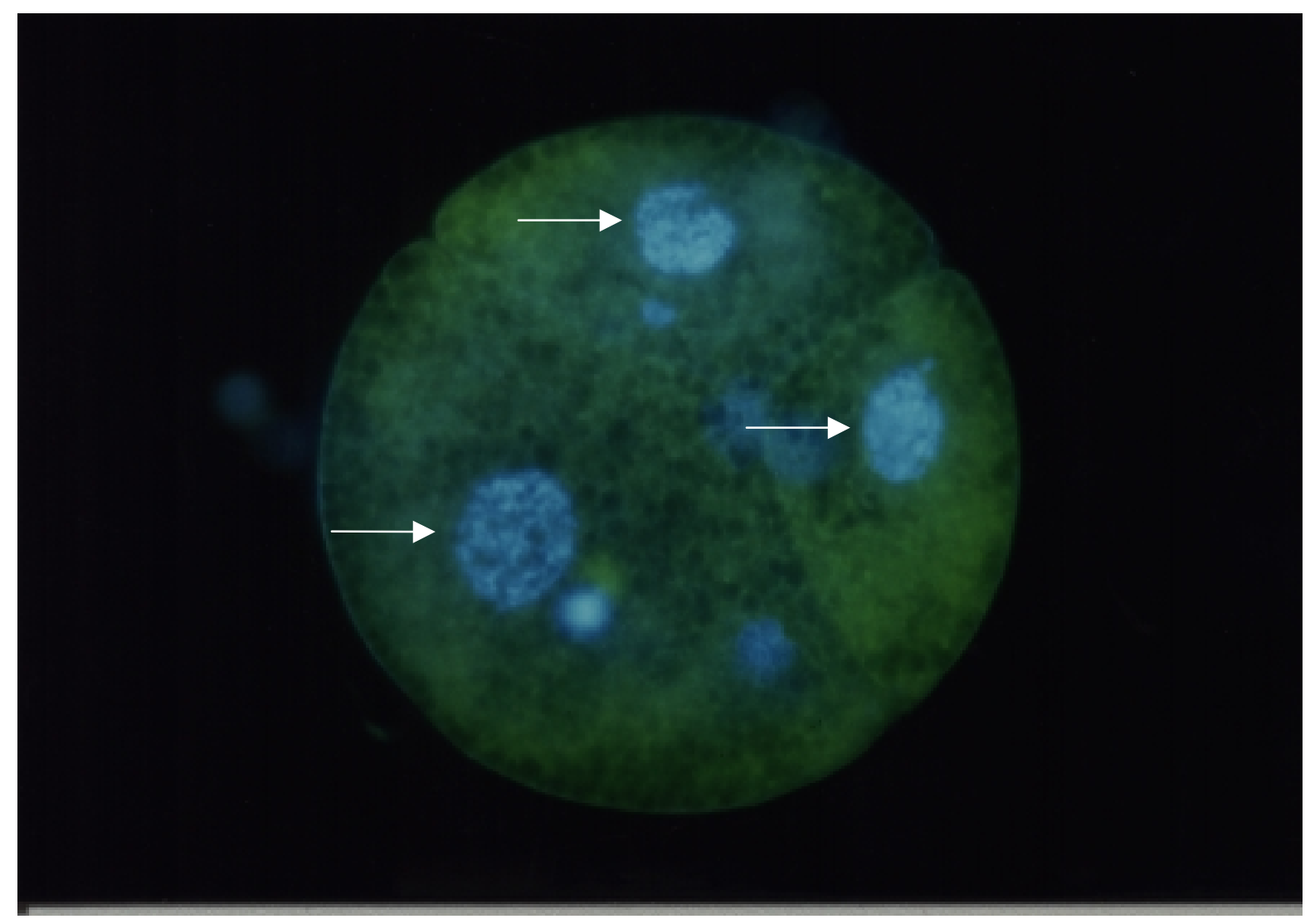

Abb. 11: Kombinierte FDA (grün) und Hoechst A 33342 (blau)-Färbung eines Embryos mit drei Zellkernen (kleine Pfeile)

\subsection{Interaktion von Eileiterfeederlayern in Maturation und Kultur porciner Oozyten und Embryonen (Versuch 8)}

Da aus den vorhergehenden Versuchen deutlich wurde, daß der Einsatz von Feederlayern während der Maturation einen positiven Einfluß hat, wurden in diesem Versuch Eileiter- und BRL-Feederlayer auch innerhalb der 2-tägigen Kultivierungsphase eingesetzt (Tabelle 6). In allen Versuchsgruppen wurde porcine Follikelflüssigkeit als die Proteinquelle während der Maturation eingesetzt, da aus den vorhergehenden Versuch deutlich wurde, daß der Einfluß der Serumkomponente $\mathrm{zu}$ vernachlässigen ist und der Einsatz von Anti-Inhibin keinen signifikanten Effekt auf die Reifung von porcinen Oozyten ausübte. Es wurden 9 Versuchsgruppen aufgestellt (Tabelle 6). 
Die Beurteilung der Erfolgsrate erfolgte nach demselben Schema wie im Versuch zuvor (Bestimmung der Teilungsrate, Anzahl lebender Oozyten nach Befruchtung und Embryonen mit zwei oder mehr Zellkernen).

Für diesen Versuch wurden 686 Oozyten in vier Wiederholungen benutzt (Tabelle 18).

Tabelle 6: Übersicht der Versuchsgruppen von Versuch 8 zur Maturation porciner Oozyten mit anschließender Embryokultur auf Feederlayern.

\begin{tabular}{|c|c|c|}
\hline Gruppe & Feederlayer in der Maturation & Feederlayer in der Kultur \\
\hline 1 & $\mathrm{BRL}+\mathrm{pFF}$ & BRL \\
\hline 2 & $\mathrm{BRL}+\mathrm{pFF}$ & $\mathrm{pEIL}$ \\
\hline 3 & $\mathrm{BRL}+\mathrm{pFF}$ & ohne Feeder \\
\hline 4 & $\mathrm{pEIL}+\mathrm{pFF}$ & BRL \\
\hline 5 & $\mathrm{pEIL}+\mathrm{pFF}$ & $\mathrm{pEIL}$ \\
\hline 6 & $\mathrm{pEIL}+\mathrm{pFF}$ & ohne Feeder \\
\hline 7 & ohne Feeder + pFF & BRL \\
\hline 8 & ohne Feeder + pFF & $\mathrm{pEIL}$ \\
\hline 9 & ohne Feeder $+\mathrm{pFF}$ & ohne Feeder \\
\hline
\end{tabular}

\subsection{Untersuchung zur Entwicklungsfähigkeit Eileiterfeederlayer- kultivierter Oozyten (Versuch 9)}

Ein weiterer Versuchsansatz (Versuch 9) überprüfte die Frage, nach der Überlebensfähigkeit in vitro erzeugter Schweineembryonen nach Transfer von Zwei - 
und Vierzellembryonen auf synchronisierte Empfängertiere. Bisherige Versuche anderer Arbeitsgruppen zeigen, daß aus in vitro gereiften und in vitro fertilisierten Oozyten kaum Trächtigkeiten resultieren (YOSHIDA, 1987). Erst YOSHIDA et al. (1993) haben nach Transfer von in vitro gereiften und befruchteten Oozyten Trächtigkeiten erzielt. Sie benutzten aufwendige synthetische Medien für die In-vitroKultur. In eigenen Versuchen sollte deshalb versucht werden, synthetische Zusätze durch natürlich produzierte Faktoren von Feederlayer-Zellen zu ersetzten.

Zuerst wurde in vier Versuchsgruppen von jeweils 129 Oozyten in vier Wiederholungen die Teilungsrate sowie die Anzahl vitaler Oozyten und Anzhl der Kernrate nach In-vitro-Maturation und In-vitro-Befruchtung auf pEIL-Feederlayern erhoben, ohne daß ein Embryotransfer erfolgte.

Im anschließenden Versuch wurden unreife Oozyten auf Eileiterzellen maturiert und nach Befruchtung auf Eileiterfeederlayer kultiviert. Parallel wurden in vivo gereifte Oozyten in vitro befruchtet und auch auf Eileiterfeederlayern kultiviert. Nach zwei Tagen Kultur wurden die Oozyten beider Versuchsgrupppen auf synchronisierte Empfängersauen übertragen. Für den Versuchsdurchgang mit anschließendem Embryonentransfer (in vitro und in vivo gereifte Oozyten) wurden die Embryonen nur morphologisch begutachtet und für den Transfer vorbereitet. Nicht geteilte Oozyten wurden mit Lacmoid angefärbt, um eine Aussage über ihren Entwicklungsstatus treffen zu können (Tabelle 9, Tabelle 21).

Die Versuchsgruppe 1 der in vitro gereiften Oozyten mit Eileiterfeederlayern in der Maturation und Kultur umfaßte 459 Oozyten, die auf die übliche Weise aus den Ovarien präpuberaler Jungsauen gewonnen wurden. Diese Oozyten wurden auf einem Feederlayer aus Eileiterzellen für 46 Stunden in TCM199 gereift.

Die Gruppe 2 umfaßte 191 in vivo gereifte Oozyten. Diese Oozyten wurden aus den Ovarien hormonstimulierter Jungsauen gewonnen. Anschließend wurden beide Gruppen in vitro befruchtet und jeweils für 2 Tage auf einem Eileiterfeederlayer kultiviert. Am Tag des Embryotransfers wurden aus beiden Gruppen geteilte Embryonen für den nachfolgenden Transfer ausselektiert. Oozyten, die keine Teilung aufwiesen, wurden mittels Lacmoidfärbung auf ihren Entwicklungsstatus untersucht. Die Versuche wurden viermal wiederholt

Die Trächtigkeitsdiagnose erfolgte am 28. Tag nach Transfer mit Ultraschall.

Die Versuche wurden viermal wiederholt 
Tabelle 7: In-vitro Maturation und Kultur auf Eileiterfeederlayern (Versuch 9)

\begin{tabular}{cccc}
\hline & \multicolumn{2}{c}{ Maturation } & \multicolumn{1}{c}{ Kultur } \\
Versuchsgruppe & Proteinquelle Feederlayer & Feederlayer \\
1 & $10 \% \mathrm{pFF}$ & Eileiter & Eileiter \\
2 & $10 \% \mathrm{pFF}$ & Eileiter & ohne \\
3 & $10 \% \mathrm{pFF}$ & ohne & Eileiter \\
4 & & & ohne \\
& $10 \% \mathrm{pFF}$ & ohne & \\
\hline
\end{tabular}

\subsection{7. Übertragung von 2 Tage alten Embryonen auf Empfängersauen}

Zur Überprüfung ihrer Vitalität wurden die in vitro erzeugten Embryonen auf synchronisierte Empfängersauen (BLUM \& HOLTZ, 1992) übertragen. Dazu wurden präpuberale Jungsauen aus dem Versuchsgut Relliehausen mit einem durchschnittlichen Gewicht von 100kg sechs Tage vor dem geplanten Transfer mit 1000I.E. PMSG (Intergonan, Intervet, Toenisvorst) und nach weiteren 72 Stunden mit 500I.E. hCG (Ovogest , Intervet, Toenisvorst ) intramuskulär vorbehandelt.

\subsubsection{Embryotransfer}

Einen Tag vor dem vorgesehenden Transfertermin wurden die Empfängertiere genüchtert, um Kreislaufprobleme während der Operation zu minimieren. Weiterhin wurde von jedem Empfängertier eine Blutprobe zur Progesteronbestimmung entnommen. Die Untersuchung erfolgte mit einem Enzymimmunoassay. Nur Tiere mit einem Progesteronwert $>6 \mathrm{ng} / \mathrm{ml}$ wurden als Empfängertier zugelassen.

Zur Ruhigstellung der Sauen wurden jeweils 5-6ml Stresnil (Janssen, Neuss, 1ml/20 kg KGW) intramuskulär injiziiert. Danach wurden die Tiere intravenös mit $8-10 \mathrm{ml}$ Hypnodil (Janssen, Neuss, 1,5ml/20kg KGW) sediert. Nun wurden die Sauen entlang 
des Gesäuges mit warmen Wasser, Seife und einer Bürste gewaschen und abgetrocknet und dann rücklings auf den Operationstisch verlagert. Nach Jodierung des Bauches im kaudalen Bereich wurde mit sterilen Papiertüchern so gewischt, daß die Flüssigkeitsentfernung von der Linea alba aus zu den Seiten hin vorgenommen wurde. Jetzt wurde der Bauch mit einem sterilen OP-Tuch (Secu-Drape, 75x75 cm, Sengewald, Rohrdorf) abgedeckt und an den Ecken mit jeweils einer Klammer fixiert. In Höhe der beiden kaudalen Zitzenpaare wurden die Haut und Bauchdecke durch einen etwa $10 \mathrm{~cm}$ langen Skalpellschnitt entlang der Linea alba eröffnet. Durch vorsichtiges Tasten mit den Fingern konnte nun der Operateur die Ovarien lokalisieren und vorlagern. Nachdem eine Gelbkörperbeurteilung beider Ovarien erfolgt war, wurden die Uterushörner ebenfalls vorgelagert, so daß die Eileiter gut erreichbar waren. Nun wurde ein Transferkatheter aus dem Humanbereich (Labotect, Göttingen), der die Embryonen enthielt, vorsichtig durch die Bursa ovarica in den Eileiter eingeführt. Nach dem Einspülen der Embryonen mit 20 $\mu 1$ NCSU23-Medium wurde der Katheter durch vorsichtiges Zurückziehen aus dem Organ entfernt. Jeweils neun Embryonen wurden in jeden Eileiter transferiert. Nachdem der Bauchraum der Sau mit warmer 0,9\%iger NaCl-Lösung gespült wurde, um das Risiko von Verwachsungen zu minimieren, wurde die Bauchhöhle durch Nähen der Bauchfascien und der Haut geschlossen. Jedes Tier erhielt nach Beendigung der Operation intramuskulär Tardomyocel (Bayer, Leverkusen, 3ml/50kg KGW).

\subsection{Statistische Auswertung}

Die in der vorliegenden Arbeit ermittelten Ergebnisse wurden im Datenbankprogramm dbase Version 3 plus gesammelt. Die varianzanalytische Auswertung erfolgte mit der GLM Prozedur des Statistikprogrammes SAS. Unterschiede zwischen den Versuchsgruppen der Versuche 1,2, 3 und 6 wurden mittels Chi-Quadrat-Test untersucht. In den Versuchen 4, 5, 7, 8 und 9 wurden signifikante Unterschiede mit dem Tukey`s Studentized Range Test überprüft. 


\section{Ergebnisse}

\subsection{Reifung follikullärer Oozyten des Schweines in unterschiedlichen Konzentrationen etalen Kälberserums (FKS) (Versuch 1).}

Wie aus Tabelle 8 hervorgeht, blieben von den in-vitro gereiften Oozyten nach der Giemsa-Färbung 532 (56,8\%) angefärbte Oozyten über, die zu einer Aussage über die Chromosomenkonstellation herangezogen werden konnten. Die restlichen 43,2\% gingen während des Prozesses der Anfärbung verloren.

Oozyten der Gruppe 1 ohne FKS-Zusatz zeigten sowohl in der Reifungsrate (= Prozent angefärbter Metaphase II-Oozyten) mit 27\% als auch bei der Klassifizierung des expandierten Kumulus (Abb. 1) mit 17\% die schlechtesten Ergebnisse. Versuchsgruppe 2 mit dem Zusatz von 1\% FKS erzielte eine Metaphase II-Reifung der Oozyten von $50 \%$, allerdings mit nur 23\% vorzüglich expandierten Kumuli. Der Einsatz von 5\% FKS erbrachte $\mathrm{zu} 48 \%$ eine vollständige nukleare Reifung der Oozyten sowie einen ausgezeichnet expandierten Kumulus (47\%). Der Zusatz von 10\% FKS zum Reifungsmedium bewirkte nur eine Maturationsrate von 39\% mit 37\% vorzüglichen Kumulusexpansionen. Die Versuchsgruppen 1-4 unterschieden sich nicht signifikant $(\mathrm{p}<0,05)$ bezüglich des Merkmals der Metaphase II-Konstellation.

\subsection{In-vitro-Reifung porciner Oozyten mit Anti - hInhibin- $\alpha$ Ziegenserum und hitzeinaktiviertem Ziegenserum als Proteinquelle (Versuch 2).}

Die Ergebnisse des zweiten Versuches sind in Tabelle 9 dargestellt. Der Zusatz von 10\% Follikelflüssigkeit ( $\mathrm{pFF}$ ) zum Basismedium TCM199 erbrachte mit 83\% Metaphase II-Konstellationen die besten Reifungsraten. Diese Gruppe unterschied sich signifikant von allen anderen Versuchsgruppen $(p<0,05)$. Auch waren die KOK`s nach ihrem morphologischen Erscheinungsbild zu 87\% der besten Klasse zuzuordnen. Mit 10\% FKS wiesen 68\% der Oozyten die Chromosomenkonstellation der Metaphase II auf, allerdings wurden nur 39\% als vorzüglich expandiert beurteilt. Hitzeinaktiviertes Ziegenserum (ZS) übte keinen fördernden Effekt auf die Reifung der Schweineoozyten aus (47\% MII; 7\% Klasse I). Die Versuchsgruppen mit 1\% bzw. 0,1\% Anti-inhibinhaltigem Ziegenserum (ZS Anti-INH; Versuchsgruppe 4 und 5.) erzielten höhere Maturationsraten (61\% bzw. 70\%) als die Kontrollversuchsgruppe 3 mit 10\% hitzeinaktiviertem Ziegenserum (47\%) . Allerdings war die morphologische Erscheinung der Kumulus-Oozyten-Komplexe der Gruppen 4 und 5 nach der Reifung 
nicht zufriedenstellend (14\% bzw. 12\%). Die Kontrollgruppen 6 und 7 mit nicht hitzeinaktiviertem Ziegenserum ohne Antikörper gegen Inhibin (ZS ak.) lieferten geringere prozentuale Maturationsraten (64\% und 61\%) und jeweils die schlechtesten Ergebnisse bezüglich der expandierten Kumuli (9\% bzw. 13\%).

Tabelle 8 Versuch 1: In-vitro-Maturation porciner Oozyten mit unterschiedlichen Konzentrationen an Fetalem Kälberserum (FKS) und anschließender Beurteilung der expandierten Kumulus-Oozyten-Komplexe (KOK`s), sowie deren nukleare Reife mittels Giemsa-Färbung ( Anzahl 4 Wiederholungen)

\begin{tabular}{ccccccccc}
\hline $\begin{array}{c}\text { FKS- } \\
\text { Konzentration } \\
\%\end{array}$ & $\begin{array}{c}\text { Anzahl } \\
\text { Oozyten }\end{array}$ & \multicolumn{2}{c}{ Qualität der KOK`s (\%) } & $\begin{array}{c}\text { Anzahl } \\
\text { gefärbter } \\
\text { Oozyten }\end{array}$ & $\bar{X}$ & MII Oozyten (\%) \\
\hline 0 & 192 & 17 & 40 & 36 & 7 & 114 & 27,0 & 1,1 \\
1 & 227 & 23 & 34 & 13 & 30 & 129 & 49,8 & 11,6 \\
5 & 259 & 47 & 28 & 20 & 5 & 154 & 47,8 & 11,5 \\
10 & 258 & 37 & 35 & 18 & 10 & 135 & 39,2 & 2,1 \\
\hline
\end{tabular}

z: Die prozentuale Angabe bezieht sich auf eine morphologische Beurteilung der expandierten Kumulus-Oozyten Komplexe nach der Reifung

I: Vorzüglich expandierte Kumulus-Oozyten-Komplexe

II: Gut expandierte Kumulus-Oozyten-Komplexe

III: Mäßig expandierte Kumulus-Oozyten-Komplexe

IV: Keine Expansion des Kumulus-Oozyten-Komplexes

\subsection{In-vitro-Reifung porciner Oozyten mit Anti - hInhibin- $\alpha$ und porciner Follikelflüssigkeit als Proteinquelle (Versuch 3).}

Die Ergebnisse sind Tabelle $10 \mathrm{zu}$ entnehmen. Der höchste Anteil an Oozyten, die die Metaphase II erreicht haben, wurde in der Kontrollgruppe mit 10\% pFF (Gruppe 1, 86\%) beobachtet. Diese Versuchsgruppe verhält sich gegenüber allen anderen Gruppen diees Versuches signifikant verschieden. Der niedrigste Anteil Metaphase IIKonstellationen wurde in Gruppe 5 mit $5 \% \mathrm{pFF}+5 \%$ nicht hitzeinaktiviertem Ziegenserum (59\%) beobachtet. In den Maturationsmedien mit Anti-Inhibin in den 
Konzentrationen von 5 und 1\% (Gruppe 2 und 3) wurden mit jeweils $70 \%$ und $72 \%$ höhere Maturationsraten erzielt als in Maturationsmedien mit der geringeren AntiInhibin-Konzentration von $0,1 \%$. Auch diese Unterschiede waren signifikant $\left(\mathrm{Chi}^{2}\right.$, $\mathrm{p}<0,05)$. Die Kontrollgruppen mit nicht hitzeinaktiviertem Ziegenserum ohne AntiInhibin (Versuchsgruppen 6 und 7) zeigten Reifungsraten von 67 und $71 \%$.

\subsection{In-vitro-Reifung von Schweineoozyten auf Feederlayern (Versuch 4).}

In Tabelle 11 sind die Ergebnisse dieses Versuches aufgeführt. Die besten Ergebnisse, d.h. der höchste Anteil an Metaphase II-Stadien wurde in der 3. Versuchsgruppe mit einem BRL-Feeder und 10\% porciner Follikelflüssigkeit in der Maturationskultur erzielt (88\%). Das deutlich schlechteste Ergebnis lieferte die Vesuchsgruppe 10 (Kontrolle) ohne Serumanteil und ohne Feederlayer (40\%). Alle Versuchsgruppen ohne Feederlayer (1, 4, 7, 10) zeigten gegenüber der Versuchsgruppen mit einem Feederlayer in der Maturationskultur signifikant schlechtere Reifungsraten (78, 69, 63 und 40\%). Bei der Betrachtung des jeweils eingesetzten Serumtyps der Versuchsgruppen 1 bis 3 (mit pFF), 4 bis 6 (mit Anti-Inhibin) 7 bis 9 (mit nicht hitzeinaktiviertem Ziegenserum) und 10 bis 12 (ohne Serum) zeigte im Durchschnitt der jeweils drei Versuchsgruppen ein Erreichen der Metaphase II von 84, 76, 69 und $65 \%$. In diesen Serumgruppen ließ sich bezüglich der Reifungsrate kein signifikanter Unterschied feststellen. Die Versuchsgruppen 1, 4, 7, 10 (ohne Feederlayer), 2, 5, 8, 11 (mit pEIL-Feederlayer) und 3, 6, 9, 12 (mit BRL-Feederlayer) zeigten im Durchschnitt 62,8, 79,3 und 79,0\% Reifungsrate. Zwischen den Feederlayertypen (BRL und pEIL) bestand kein signifikanter Unterschied, jedoch waren die Versuchsgruppen mit einem der beiden Feederlayer in der Maturationskultur gegenüber einer Kultur ohne Feederlayer signifikant überlegen. 
Tabelle 9: Versuch 2: Reifung von Schweineoozyten in Anti-inhibin supplementierten Medien mit anschließender Beurteilung der Expansion des Kumulus oophorus sowie Dokumentation der nuklearen Reife (Metaphase II) mittels Giemsa-Färbung (Anzahl Wiederholungen = 9)

\begin{tabular}{|c|c|c|c|c|c|c|c|c|c|}
\hline \multirow{2}{*}{$\begin{array}{l}\text { Versuchs- } \\
\text { Gruppe }\end{array}$} & \multirow[t]{2}{*}{ Zusatz zu TCM199 } & \multirow{2}{*}{$\begin{array}{l}\text { Anzahl } \\
\text { Oozyten }\end{array}$} & \multicolumn{4}{|c|}{ Qualität der KOK`s $(\%)^{z}$} & \multirow{2}{*}{$\begin{array}{l}\text { Anzahl } \\
\text { angefärbte } \\
\text { Oozyten }\end{array}$} & \multicolumn{2}{|c|}{ MII - Oozyten \% } \\
\hline & & & $\mathrm{I}$ & II & III & IV & & $\bar{X}$ & $\mathrm{SD}$ \\
\hline 1 & $10 \% \mathrm{pFF}$ & 286 & 87 & 2 & 7 & 4 & 204 & $83,2^{\mathrm{a}}$ & 6,1 \\
\hline 2 & $10 \% \mathrm{FKS}$ & 307 & 39 & 23 & 32 & 6 & 107 & $68,1^{\mathrm{b}}$ & 5,6 \\
\hline 3 & $10 \%$ inaktiv. ZS & 283 & 7 & 16 & 69 & 8 & 105 & $46,5^{\mathrm{c}}$ & 5,8 \\
\hline 4 & $9 \%$ inaktiv. ZS+1\%Anti-INH & 289 & 14 & 22 & 57 & 7 & 119 & $60,8^{\mathrm{b}}$ & 7,1 \\
\hline 5 & $9,9 \%$ inaktiv.ZS+0,1\%AntiINH & 162 & 12 & 9 & 66 & 13 & 157 & $69,6^{\mathrm{b}}$ & 5,8 \\
\hline 6 & $9 \%$ inaktiv. $\mathrm{ZS}+1 \%$ aktiv. $\mathrm{ZS}$ & 278 & 9 & 3 & 74 & 14 & 129 & $64,4^{\mathrm{b}}$ & 6,4 \\
\hline 7 & $9,9 \%$ inaktiv. $\mathrm{ZS}+0,1 \%$ aktiv.ZS & 267 & 13 & 16 & 61 & 10 & 118 & $61,3^{\mathrm{b}}$ & 5,6 \\
\hline
\end{tabular}

a,b,c: Werte mit unterschiedlichen Indices unterscheiden sich signifikant $\left(\mathrm{p}<0,05, \mathrm{Chi}^{2}\right.$-Test $)$

z: Vgl. Tab. 8 pFF=porcine Follikelflüssigkeit; FKS=Fetales Kälberserum, ZS=Ziegenserum; INH=Inhibin 
Tabelle 10: Versuch 3: Verteilung der Oozyten auf die verschiedenen Phasen der Meiose nach 46 stündiger Reifung in Maturationsmedium, das mit $\mathrm{pFF}$, antikörperhaltigem Ziegenserum bzw. nicht hitzeinaktiviertem Ziegenserum supplementiert war. (Anzahl Wiederholungen $=4)$.

\begin{tabular}{|c|c|c|c|c|c|c|c|c|c|c|}
\hline \multirow{2}{*}{$\begin{array}{l}\text { Versuchs- } \\
\text { gruppe }\end{array}$} & \multirow[t]{2}{*}{ Zusatz zu TCM199 } & \multirow{2}{*}{$\begin{array}{l}\text { Oozyten } \\
\text { Gesamt }\end{array}$} & \multirow[b]{2}{*}{$G V$} & \multicolumn{4}{|c|}{ GV bis TeloI-Oozyten (\%) } & \multirow[b]{2}{*}{ TeloI } & \multicolumn{2}{|c|}{ MII-Oozyten\% } \\
\hline & & & & $G V B D$ & PrometI & $M I$ & AnaI & & $\bar{X}$ & $\mathrm{SD}$ \\
\hline 1 & $10 \%$ porcine Follikelflüssigkeit (pFF) & 61 & 9,8 & 0 & 0 & 4,9 & 1,6 & 0 & $85,9^{a}$ & 3,7 \\
\hline 2 & $5 \% \mathrm{pFF}+5 \%$ anti - INH-haltiges $\mathrm{ZS}$ & 86 & 6,9 & 2,3 & 9,3 & 8,1 & 0 & 2,3 & $70,1^{\mathrm{b}}$ & 3,7 \\
\hline 3 & $9 \% \mathrm{pFF}+1 \%$ anti - INH-haltiges $\mathrm{ZS}$ & 66 & 12,1 & 4,5 & 1,5 & 9,0 & 1,5 & 0 & $71,5^{\mathrm{b}}$ & 2,3 \\
\hline 4 & $9,9 \% \mathrm{pFF}+0,1 \%$ anti - INH-haltiges ZS & 74 & 21,6 & 1,3 & 1,3 & 9,4 & 1,3 & 0 & $67,0^{\mathrm{c}}$ & 2,2 \\
\hline 5 & $5 \% \mathrm{pFF}+5 \%$ nicht hitzeinaktiv. ZS & 48 & 27,0 & 2,1 & 8,3 & 2,1 & 2,1 & 0 & $58,7^{\mathrm{c}}$ & 2,2 \\
\hline 6 & $9 \% \mathrm{pFF}+1 \%$ nicht hitzeinaktiv. ZS & 76 & 14,5 & 1,3 & 7,9 & 7,9 & 1,3 & 0 & $66,5^{\mathrm{c}}$ & 5,1 \\
\hline 7 & $9,9 \% \mathrm{pFF}+0,1 \%$ nicht hitzeinaktiv. ZS & 72 & 19,4 & 0 & 5,5 & 6,9 & 0 & 0 & $71,1^{\mathrm{b}}$ & 2,3 \\
\hline
\end{tabular}

a,b,c: Werte mit unterschiedlichen Indices unterscheiden sich signifikant $\left(\mathrm{p}<0,05, \mathrm{Chi}^{2}\right.$-Test $)$

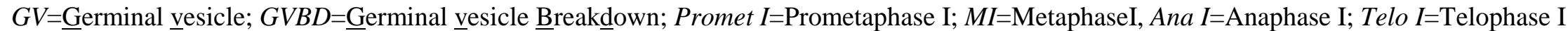

MII=MetaphaseII INH=Inhibin $\quad$ ZS=Ziegenserum 

Tabelle 11: Versuch 4: Einfluß von Eileiter- und Buffalo-Rat-Liver (BRL)-Feederlayern in Kombination mit Inhibin-Antiserum oder nicht hitzeinaktiviertem Serum auf die Reifung porciner Oozyten (Anzahl Wiederholungen $=4$ )

\begin{tabular}{|c|c|c|c|c|c|c|c|c|c|}
\hline \multirow{2}{*}{$\begin{array}{l}\text { Versuch } \\
\text { gruppe }\end{array}$} & \multicolumn{2}{|c|}{ Zusatz zu TCM199 } & \multicolumn{4}{|c|}{ Anzahl der eingesetzten Oozyten } & \multicolumn{3}{|c|}{ MII-Oozyten (\%) } \\
\hline & Proteinquelle & Feederlayer & Gesamt & $\bar{X}$ & $\mathrm{SD}$ & Min-Max & $\bar{X}$ & $\mathrm{SD}$ & Min-Max \\
\hline 1 & $10 \% \mathrm{pFF}$ & ohne & 103 & 25,8 & 3,6 & $22-31$ & $78,3^{\mathrm{a}}$ & 8,4 & $70-87$ \\
\hline 2 & $10 \% \mathrm{pFF}$ & Eileiter & 116 & 29,0 & 6,3 & $20-37$ & $85,1^{\mathrm{b}}$ & 12,3 & $72-100$ \\
\hline 3 & $10 \% \mathrm{pFF}$ & BRL & 95 & 23,8 & 2,7 & $21-27$ & $87,9^{\mathrm{b}}$ & 7,1 & $81-100$ \\
\hline 4 & $9 \% \mathrm{pFF}+1 \%$ Anti-INH. & ohne & 96 & 24,0 & 3,0 & $21-29$ & $68,9^{a}$ & 10,0 & $52-76$ \\
\hline 5 & $9 \% \mathrm{pFF}+1 \%$ Anti-INH. & Eileiter & 93 & 23,3 & 2,0 & $20-25$ & $80,8^{b}$ & 6,1 & $72-88$ \\
\hline 6 & $9 \% \mathrm{pFF}+1 \%$ Anti-INH. & BRL & 97 & 24,3 & 5,4 & $17-32$ & $78,4^{\mathrm{b}}$ & 7,2 & $71-87$ \\
\hline 7 & $9 \% \mathrm{pFF}+1 \% \mathrm{ZS} \mathrm{ak}$ & ohne & 71 & 23,6 & 8,8 & $16-36$ & $63,2^{\mathrm{a}}$ & 4,7 & $58-69$ \\
\hline 8 & $9 \% \mathrm{pFF}+1 \% \mathrm{ZS}$ ak & Eileiter & 98 & 24,5 & 2,7 & $20-27$ & $73,6^{\mathrm{b}}$ & 14,3 & 56-95 \\
\hline 9 & $9 \% \mathrm{pFF}+1 \% \mathrm{ZS}$ ak & BRL & 94 & 23,5 & 2,3 & $17-30$ & $70,0^{\mathrm{b}}$ & 13,3 & $58-90$ \\
\hline 10 & ohne & ohne & 100 & 25,0 & 4,1 & $20-30$ & $39,8^{a}$ & 11,7 & $23-55$ \\
\hline 11 & ohne & Eileiter & 74 & 18,5 & 5,2 & $11-25$ & $78,7^{\mathrm{b}}$ & 13,5 & $64-100$ \\
\hline 12 & ohne & BRL & 109 & 27,3 & 4,4 & $22-33$ & $78,9^{\mathrm{b}}$ & 13,5 & $63-97$ \\
\hline
\end{tabular}

Werte mit unterschiedlichen Indices unterscheiden sich signifikant ( $\mathrm{p}<0,05$,Tukey`s Studentized Range Test)

INH= Inhibin; ZS ak= nicht hitzeinaktiviertes Ziegenserum 


\subsection{In-vitro-Befruchtung von Oozyten, die mit einem antikörperhaltigen Ziegenserum in porciner Follikelflüssigkeit gereift wurden (Versuch 5).}

Die Ergebnisse sind in Tabelle 12 zusammengefaßt. Die höchste Entwicklungsrate wurde in Gruppe 6 beobachtet (34\%), die niedrigste Entwicklungsfähigkeit zeigten Oozyten der Gruppen 1 und 2 mit jeweils 25\%.

Sowohl die Gruppen 3 (32\% Teilungsrate) und 4 (32\% Teilungsrate), die mit antiinhibinhaltigem Ziegenserum supplementiert worden waren, als auch die Gruppen 5, 6 und 7 (32\%, 34\% und 32\%) lagen bezüglich der Entwicklungsrate über der mit ausschließlich pFF supplementierten Gruppe. Die Versuchsgruppen 5, 6 und 7 (mit Anti-Inhibin) lagen im Mittel der Teilungsrate (32\%) über dem Mittel der Teilungsrate der Gruppen 2, 3 und 4 deren Medium mit nicht hitzeinaktiviertem Ziegenserum supplementiert worden war (29\%).

Bei dem Vergleich der Ergebnisse von Versuchs 3 und 5 (Tabelle 13) läßt sich Folgendes feststellen: Die Gruppe 1 mit der besten Maturationsrate zeigt in der Entwicklungsrate mit $25 \%$ die niedrigste Erfolgsrate bezüglich der Embryonenentwicklung. Die in Anti-Inhibin gereiften Oozyten der Versuchsgruppen 2,3 und 4 zeigen im Mittel eine Maturationsrate von 69\%, die Kontrollgruppen 5, 6 und 7 mit nicht hitzeinaktiviertem Ziegenserum nur 64\%. Bei der Betrachtung der jeweiligen Teilungsraten weisen die Anti-Inhibin supplementierten Gruppen im Mittel über alle drei Gruppen 29\% geteilte Stadien auf, die Gruppen mit nicht hitzeinaktiviertem Ziegenserum durchschnittlich $32 \%$. Somit ergibt sich, daß 50\% der nuklear reifen Oozyten, die mit unterschiedlichen Konzentrationen nicht hitzeinaktiviertem Ziegenserum gereift wurden auch befruchtungs- und teilungsfähig sind. Dagegen sind Oozyten aus Anti - Inhibin supplementierten Medien nur zu 42\% befruchtungs- und teilungsfähig. 
Tabelle 12: Versuch 5: Teilungsrate porciner Oozyten, die in Maturationsmedien mit porciner Follikelflüssigkeit bzw. unterschiedlichen Konzentrationen antikörperhaltigen Ziegenserum oder nicht hitzeinaktiviertem Ziegenserum gereift wurden. (Anzahl Wiederholungen = 4)

\begin{tabular}{|c|c|c|c|c|c|c|c|c|c|}
\hline \multirow{3}{*}{ Gruppe } & \multirow{3}{*}{ TCM 199 plus } & \multirow{3}{*}{$\begin{array}{c}\text { Anzahl } \\
\text { Oozyten }\end{array}$} & \multicolumn{6}{|c|}{ Teilungsstadien } & \multirow{3}{*}{$\begin{array}{c}\text { Teilungsrate }^{z} \\
\%\end{array}$} \\
\hline & & & \multicolumn{2}{|c|}{ UFOy } & \multicolumn{2}{|c|}{ 2-4 Zeller } & \multicolumn{2}{|c|}{$>4$-Zeller } & \\
\hline & & & $\mathrm{n}$ & $\%$ & $\mathrm{n}$ & $\%$ & $\mathrm{n}$ & $\%$ & \\
\hline 1 & $10 \% \mathrm{pFF}$ & 130 & 97 & 75 & 26 & 20 & 7 & 5 & 25 \\
\hline 2 & $5 \% \mathrm{pFF}+5 \%$ Anti-INH. & 109 & 82 & 75 & 19 & 17 & 8 & 7 & 25 \\
\hline 3 & $9 \% \mathrm{pFF}+1 \%$ Anti-INH. & 112 & 76 & 68 & 25 & 22 & 10 & 9 & 32 \\
\hline 4 & $9,9 \% \mathrm{pFF}+0,1 \%$ AntINH. & 118 & 80 & 68 & 26 & 22 & 12 & 10 & 32 \\
\hline 5 & $5 \% \mathrm{pFF}+5 \% \mathrm{ZS} \mathrm{ak}$ & 117 & 80 & 68 & 30 & 26 & 7 & 6 & 32 \\
\hline 6 & $9 \% \mathrm{pFF}+1 \% \mathrm{ZS} \mathrm{ak}$ & 139 & 92 & 66 & 37 & 27 & 10 & 7 & 34 \\
\hline 7 & $9,9 \% \mathrm{pFF}+0,1 \% \mathrm{ZS}$ ak & 131 & 89 & 68 & 31 & 24 & 11 & 8 & 32 \\
\hline
\end{tabular}

\footnotetext{
$\mathrm{y}=$ unbefruchtete Oozyte $\quad{ }^{\mathrm{z}}=$ Summe der Teilungstadien/Anzahl Oozyten
}

Anti-INH= gegen Inhibin antikörperhaltiges Ziegenserum ohne Hitzeinaktivierung ; ZS ak.= Ziegenserum ohne Antikörper gegen Inhibin ohne Hitzeinaktivierung (Kontrolle) 
Tabelle 13: Versuch 3 und 5: Vergleich zwischen prozentual gereiften und befruchteten Oozyten nach Maturation mit porciner Follikelflüssigkeit bzw. unterschiedlichen Konzentrationen nicht hitzeinaktiviertem antikörperhaltigem - oder keine Antikörper enthaltedem Ziegenserum.

\begin{tabular}{|c|c|c|c|}
\hline Gruppe & Zusatz zu TCM199 & $\begin{array}{c}\text { MII Oozyten } \\
\%\end{array}$ & $\begin{array}{c}\text { geteilte Oozyten } \\
\%\end{array}$ \\
\hline 1 & $10 \% \mathrm{pFF}$ & $86^{\mathrm{a}}$ & 25 \\
\hline 2 & $5 \% \mathrm{pFF}+5 \%$ AntiINH. & $70^{\mathrm{b}}$ & 25 \\
\hline 3 & $9 \% \mathrm{pFF}+1 \%$ AntiINH. & $72^{\mathrm{b}}$ & 32 \\
\hline 4 & $9,9 \% \mathrm{pFF}+0,1 \%$ AntiINH & $67^{\mathrm{c}}$ & 32 \\
\hline 5 & $5 \% \mathrm{pFF}+5 \% \mathrm{ZS}$ ak. & $58^{\mathrm{c}}$ & 32 \\
\hline 6 & $9 \% \mathrm{pFF}+1 \% \mathrm{ZS}$ ak. & $67^{\mathrm{c}}$ & 34 \\
\hline 7 & $9,9 \% \mathrm{pFF}+0,1 \% \mathrm{ZS}$ ak. & $71^{\mathrm{c}}$ & 32 \\
\hline
\end{tabular}

a,b,c: Werte mit unterschiedlichen Indices unterscheiden sich signifikant ( $\mathrm{p}<0,05, \mathrm{Chi}^{2}$-Test)

Anti-INH= gegen Inhibin antikörperhaltiges Ziegenserum ohne Hitzeinaktivierung ZS ak.= Ziegenserum ohne Antikörper gegen Inhibin ohne Hitzeinaktivierung (Kontrolle) 


\subsection{In-vitro-Befruchtung von Oozyten, die mit einem antikörperhaltigen Ziegenserum in porciner Follikelflüssigkeit und zusätzlich auf Eileiter- bzw. BRL- Feederlayern gereift wurden (Versuch 6).}

In Tabelle 14 sind die Ergebnisse dieses Versuches zusammengefaßt. Die höchste Teilungsrate trat in Gruppe 6 (mit Anti-Inhibin und BRL-Feederlayer), (38\%) die niedrigste in Gruppe 10 ohne Serum und Feederlayer auf (21\%). Die Versuchsgruppen 1 bis 3 (mit pFF), 4-6 (mit Anti-Inhibin) 7 bis 9 (mit nicht hitzeinaktiviertem Ziegenserum) und 10 bis 12 (ohne Serum) zeigten im Durchschnitt eine Teilungsrate von 28, 32, 30 und 26\%. In den Serumgruppen ließ sich bezüglich der Teilungsrate kein signifikanter Unterschied feststellen. Die Versuchsgruppen 1, 4, 7, 10 (ohne Feederlayer), 2, 5, 8, 11 (mit pEIL-Feederlayer) und 3, 6, 9, 12 (mit BRL-Feederlayer) zeigten im Durchschnitt Teilungsraten von 26, 29, 33\%. Es bestand sowohl zwischen und innerhalb der Feederlayer- und Serumgruppen bezüglich des Merkmals Teilungsrate kein signifikanter Unterschied. 
Tabelle 14: Versuch 6: Einfluß von Eileiter- und BRL-Feederlayern in Kombination unterschiedlich supplementierter Maturationsmedien (pFF, Anti- Inhibin sowie nicht hitzeinaktiviertes Ziegenserum in verschiedenen Konzentrationen) auf Fertilisation und Teilung porciner Oozyten. (Anzahl Wiederholungen $=8$ )

\begin{tabular}{|c|c|c|c|c|c|c|c|c|}
\hline \multirow{2}{*}{$\begin{array}{l}\text { Vesuchs- } \\
\text { gruppe }\end{array}$} & \multicolumn{2}{|c|}{ Zusatz zu TCM199 } & \multicolumn{4}{|c|}{ Anzahl eingesetzter Oozyten } & \multicolumn{2}{|c|}{ Teilungsrate (\%) } \\
\hline & Proteinquelle & Feederlayer & gesamt & $\bar{X}$ & SD & Min- Max & $\bar{X}$ & $\mathrm{SD}$ \\
\hline 1 & $10 \% \mathrm{pFF}$ & ohne & 210 & 26,3 & 7,7 & $17-38$ & 26,4 & 8,2 \\
\hline 2 & $10 \% \mathrm{pFF}$ & Eileiter & 220 & 27,5 & 11,0 & $15-52$ & 24,8 & 10,5 \\
\hline 3 & $10 \% \mathrm{pFF}$ & BRL & 191 & 23,9 & 6,7 & $15-33$ & 30,9 & 17,1 \\
\hline 4 & $9 \% \mathrm{pFF}+1 \%$ Anti-INH. & ohne & 205 & 25,6 & 7,0 & $15-38$ & 26,9 & 10,3 \\
\hline 5 & $9 \% \mathrm{pFF}+1 \%$ Anti-INH. & Eileiter & 193 & 24,1 & 7,4 & $15-36$ & 30,1 & 16,0 \\
\hline 6 & $9 \% \mathrm{pFF}+1 \%$ Anti-INH. & BRL & 186 & 23,3 & 5,7 & $12-31$ & 38,3 & 21,4 \\
\hline \multirow[t]{2}{*}{7} & $9 \% \mathrm{pFF}+1 \% \mathrm{ZS}$ ak & ohne & 200 & 25,0 & 5,1 & $19-33$ & 31,8 & 9,7 \\
\hline & $9 \% \mathrm{pFF}+1 \% \mathrm{ZS}$ ak & Eileiter & 190 & 23,8 & 6,5 & $16-36$ & 28,9 & 14,5 \\
\hline 9 & $9 \% \mathrm{pFF}+1 \% \mathrm{ZS} \mathrm{ak}$ & BRL & 158 & 22,6 & 6,6 & $14-35$ & 28,6 & 14,7 \\
\hline 10 & ohne & ohne & 203 & 25,4 & 8,6 & $17-42$ & 20,5 & 7,9 \\
\hline 11 & ohne & Eileiter & 180 & 22,5 & 7,1 & $10-31$ & 30,1 & 11,3 \\
\hline 12 & ohne & BRL & 181 & 22,6 & 5,7 & $15-30$ & 27,7 & 15,7 \\
\hline
\end{tabular}

Anti-INH= gegen Inhibin antikörperhaltiges Ziegenserum ohne Hitzeinaktivierung

ZS ak.= Ziegenserum ohne Antikörper gegen Inhibin ohne Hitzeinaktivierung (Kontrolle) 


\subsection{Einfluß von Eileiter- und BRL- Feederlayern in Kombination verschiedener Konzentrationen Anti-hInhibins- $\alpha$ oder nicht hitzeinaktiviertem Ziegenserum während der Maturation auf Teilung, Vitalität und Kernmaterial porciner Oozyten nach Befruchtung (Versuch 7).}

Die Ergebnisse des folgenden Versuches sind in den Tabellen 15, 16 und 17 beschrieben. Dabei zeigt Tabelle 15 die Ergebnisse des Merkmals „Teilungsrate“, Tabelle 16 beschreibt die Ergebnisse der FDA-Färbung und Tabelle 17 die Resultate bezüglich der Hoechst A 33342-Färbung.

Die höchste Teilungsrate wurde in Gruppe $6(9 \% \mathrm{pFF}+1 \%$ Anti-INH + BRLFeederlayer) erreicht (39\%). Der höchste Anteil vitaler Oozyten wurde in Gruppe 9 beobachtet (9\% pFF+ 1\% ZS ak.+ BRL-Feederlayer, 96\%). Gruppe 11 (ohne Proteinquelle + Eileiter-Feederlayer) lieferte die meisten Oozyten mit mehr als zwei Zellkernen (54\%). Die Versuchsgruppen 1 bis 3 (mit pFF), 4 bis 6 (mit Anti-Inhibin) 7 bis 9 (mit nicht hitzeinaktiviertem Ziegenserum) und 10 bis 12 (ohne Serum) zeigten im Durchschnitt eine Teilungsrate von 30, 35, 31 und 31\%. Zwischen den Serumgruppen ließ sich bezüglich der Reifungsrate kein signifikanter Unterschied feststellen. Die Versuchsgruppen 1, 4, 7, 10 (ohne Feederlayer), 2, 5, 8, 11 (mit pEILFeederlayer) und 3, 6, 9, 12 (mit BRL-Feederlayer) zeigten im Durchschnitt 27, 33 und $36 \%$ Teilungsrate. Zwischen allen Feederlayergruppen bestand kein signifikanter Unterschied. Die Versuchsgruppen 1 bis 3 (mit pFF), 4 bis 6 (mit Anti-Inhibin) 7 bis 9 (mit nicht hitzeinaktiviertem Ziegenserum) und 10 bis 12 (ohne Serum) zeigten im Durchschnitt ein lebendes Zytoplasma von 94, 92, 92 und 90\%. In den Serumgruppen ließ sich bezüglich der Reifungsrate kein signifikanter Unterschied feststellen. Die Versuchsgruppen 1, 4, 7, 10 (ohne Feederlayer), 2, 5, 8, 11 (mit Eileiterfeederlayer) und 3, 6, 9, 12 (mit BRL-Feederlayer) zeigten im Durchschnitt 89, 95 und 93\% ein lebenden Zytoplasmas. Zwischen allen Feederlayergruppen bestand kein signifikanter Unterschied. Die Versuchsgruppen 1 bis 3 (mit pFF), 4 bis 6 (mit Anti-Inhibin) 7 bis 9 (mit nicht hitzeinaktiviertem Ziegenserum) und 10 bis 12 (ohne Serum) zeigten im Durchschnitt 44, 39, 33 und 38\% Oozyten mit zwei oder mehr Zellkernen. Die Versuchsgruppen 1, 4, 7, 10 (ohne Feederlayer), 2, 5, 8, 11 (mit pEIL-Feederlayer) und 3, 6, 9, 12 (mit BRL-Feederlayer) zeigten im Durchschnitt 26, 49 und 46\% Oozyten mit zwei oder mehr Zellkernen. Es konnte so in hochsignifikantem Maß festgestellt werden, daß ohne Feederlayer deutlich schlechtere Embryonenentwicklungen erzielt wurden. Kein Unterschied bestand bezüglich der Kernzahlen zwischen pEIL-Feederund BRL-Feederlayer. 
Tabelle 15: Versuch 7: Einfluß von Eileiter- und BRL-Feederlayern in Kombination unterschiedlich supplementierter Maturationsmedien (pFF, Anti- Inhibin sowie nicht hitzeinaktiviertes Ziegenserum in verschiedenen Konzentrationen) auf Fertilisation und Teilung porciner Oozyten.(Anzahl Wiederholungen =4)

\begin{tabular}{|c|c|c|c|c|c|c|c|c|c|}
\hline \multirow{2}{*}{$\begin{array}{l}\text { Versuchs- } \\
\text { gruppe }\end{array}$} & \multicolumn{2}{|c|}{ Zusatz zu TCM199 } & \multicolumn{4}{|c|}{ Anzahl eingesetzter Oozyten } & \multicolumn{2}{|c|}{ Teilungsrate (\%) } & \multirow[b]{2}{*}{ Min-Max } \\
\hline & Proteinquelle & Feederlayer & Gesamt & $\bar{X}$ & $\mathrm{SD}$ & Min-Max & $\bar{X}$ & $\mathrm{SD}$ & \\
\hline 1 & $10 \% \mathrm{pFF}$ & ohne & 124 & 31,0 & 7,0 & $20-38$ & 30,6 & 3,9 & $25-35$ \\
\hline 2 & $10 \% \mathrm{pFF}$ & Eileiter & 137 & 34,5 & 11,6 & $20-52$ & 27,2 & 4,2 & $10-37$ \\
\hline 3 & $10 \% \mathrm{pFF}$ & BRL & 117 & 29,25 & 4,8 & $21-33$ & 28,1 & 11,9 & $10-42$ \\
\hline 4 & $9 \% \mathrm{pFF}+1 \%$ AntiI & H ohne & 110 & 27,5 & 2,6 & $24-30$ & 27,9 & 6,2 & $21-37$ \\
\hline 5 & $9 \% \mathrm{pFF}+1 \%$ AntiI & H.Eileiter & 120 & 30,0 & 5,8 & $21-36$ & 34,6 & 12,1 & $18-47$ \\
\hline 6 & $9 \% \mathrm{pFF}+1 \%$ Anti- & JH BRL & 108 & 27,0 & 3,7 & $21-31$ & 38,9 & 23,0 & $0-59$ \\
\hline 7 & $9 \% \mathrm{pFF}+1 \% \mathrm{ZS}$ ak & ohne & 119 & 29,8 & 2,5 & $26-33$ & 27,7 & 10,4 & $10-37$ \\
\hline 8 & $9 \% \mathrm{pFF}+1 \% \mathrm{ZS}$ ak & Eileiter & 116 & 29,0 & 5,0 & $22-36$ & 28,9 & 8,8 & $18-43$ \\
\hline 9 & $9 \% \mathrm{pFF}+1 \% \mathrm{ZS}$ ak & BRL & 84 & 28,0 & 5,7 & $21-35$ & 34,5 & 19,4 & $14-61$ \\
\hline 10 & ohne & ohne & 124 & 31,0 & 9,1 & $17-42$ & 23,6 & 9,3 & $9-35$ \\
\hline 11 & ohne & Eileiter & 101 & 25,3 & 5,8 & $18-31$ & 37,4 & 2,3 & $33-38$ \\
\hline 12 & ohne & BRL & 111 & 27,8 & 2,7 & $23-30$ & 33,6 & 14,7 & $22-59$ \\
\hline
\end{tabular}

Anti-INH= gegen Inhibin antikörperhaltiges Ziegenserum ohne Hitzeinaktivierung

ZS ak.= Ziegenserum ohne Antikörper gegen Inhibin ohne Hitzeinaktivierung(Kontrolle) 
Tabelle 16: Versuch 7: Einfluß von Eileiter- und BRL-Feederlayern in Kombination unterschiedlich supplementierter Maturationsmedien (pFF, Anti- Inhibin sowie nicht hitzeinaktiviertes Ziegenserum in verschiedenen Konzentrationen) auf auf die Erhaltung lebenden Zytoplasmas porciner Oozyten.

\begin{tabular}{|c|c|c|c|c|c|c|c|c|c|}
\hline \multirow[b]{2}{*}{ Versuchsgruppe } & \multicolumn{2}{|c|}{ Zusatz zu TCM199 } & \multicolumn{4}{|c|}{ Anzahl eingesetzter Oozyten } & \multicolumn{3}{|c|}{ lebende Oozyten nach Befruchtung (\%) } \\
\hline & Proteinquelle & Feederlayer & Gesamt & $\bar{X}$ & $\mathrm{SD}$ & Min-Max & $\bar{X}$ & $\mathrm{SD}$ & Min-Max \\
\hline 1 & $10 \% \mathrm{pFF}$ & ohne & 124 & 31,0 & 7,0 & $20-38$ & 92,1 & 5,7 & 84-100 \\
\hline 2 & $10 \% \mathrm{pFF}$ & Eileiter & 137 & 34,5 & 11,6 & $20-52$ & 95,5 & 6,1 & $85-100$ \\
\hline 3 & $10 \% \mathrm{pFF}$ & BRL & 117 & 29,25 & 4,8 & $21-33$ & 93,8 & 6,1 & $88-100$ \\
\hline 4 & $9 \% \mathrm{pFF}+1 \%$ AntiINH & ohne & 110 & 27,5 & 2,6 & $24-30$ & 91,5 & 7,5 & $80-100$ \\
\hline 5 & $9 \% \mathrm{pFF}+1 \%$ AntiINH & Eileiter & 120 & 30,0 & 5,8 & $21-36$ & 93,9 & 5,0 & $86-100$ \\
\hline 6 & $9 \% \mathrm{pFF}+1 \%$ Anti-INH & BRL & 108 & 27,0 & 3,7 & $21-31$ & 89,4 & 11,8 & $71-100$ \\
\hline 7 & $9 \% \mathrm{pFF}+1 \% \mathrm{ZS} \mathrm{ak}$ & ohne & 119 & 29,8 & 2,5 & $26-33$ & 89,2 & 10,4 & $73-100$ \\
\hline 8 & $9 \% \mathrm{pFF}+1 \% \mathrm{ZS} \mathrm{ak}$ & Eileiter & 116 & 29,0 & 5,0 & $22-36$ & 92,8 & 12,4 & $71-100$ \\
\hline 9 & $9 \% \mathrm{pFF}+1 \% \mathrm{ZS} \mathrm{ak}$ & BRL & 84 & 28,0 & 5,7 & $21-35$ & 96,1 & 5,4 & $89-100$ \\
\hline 10 & ohne & ohne & 124 & 31,0 & 9,1 & $17-42$ & 87,2 & 17,4 & $57-100$ \\
\hline 11 & ohne & Eileiter & 101 & 25,3 & 5,8 & $18-31$ & 95,1 & 5,3 & $87-100$ \\
\hline 12 & ohne & $\mathrm{BRL}$ & 111 & 27,8 & 2,7 & $23-30$ & 92,2 & 11,5 & $72-100$ \\
\hline
\end{tabular}

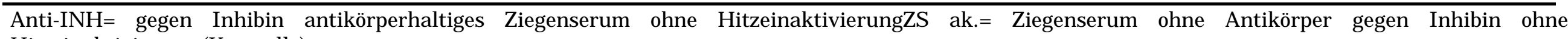
Hitzeinaktivierung (Kontrolle) 
Tabelle 17: Versuch 7: Einfluß von Eileiter- und BRL-Feederlayern in Kombination unterschiedlich supplementierter Maturationsmedien (pFF, Anti- Inhibin sowie nicht hitzeinaktiviertes Ziegenserum in verschiedenen Konzentrationen) auf das Kernmaterial porciner Embryonen.

\begin{tabular}{|c|c|c|c|c|c|c|c|c|c|}
\hline \multirow[t]{3}{*}{ Versuchsgruppe } & \multicolumn{2}{|c|}{ Zusatz zu TCM 199} & \multicolumn{4}{|c|}{ Anzahl eingesetzer Oozyten } & \multirow{2}{*}{\multicolumn{3}{|c|}{$\begin{array}{c}\text { Oozyten mit zwei oder mehr Zellkernen } \\
\frac{\text { nach Befruchtung }}{(\%)}\end{array}$}} \\
\hline & \multirow[b]{2}{*}{ Proteinquelle } & \multirow[b]{2}{*}{ Feederlayer } & \multirow[b]{2}{*}{ Gesamt } & \multirow[b]{2}{*}{$\bar{X}$} & \multirow[b]{2}{*}{$\mathrm{SD}$} & \multirow{2}{*}{ Min-Max } & & & \\
\hline & & & & & & & $\bar{X}$ & $\mathrm{SD}$ & Min-Max \\
\hline 1 & $10 \% \mathrm{pFF}$ & ohne & 124 & 31,0 & 7,0 & $20-38$ & $36,5^{\mathrm{a}}$ & 15,2 & $22-60$ \\
\hline 2 & $10 \% \mathrm{pFF}$ & Eileiter & 137 & 34,5 & 11,6 & $20-52$ & $48,4^{b}$ & 18,2 & $20-65$ \\
\hline 3 & $10 \% \mathrm{pFF}$ & BRL & 117 & 29,25 & 4,8 & $21-33$ & $48,7^{\mathrm{b}}$ & 6,6 & $41-57$ \\
\hline 4 & $9 \% \mathrm{pFF}+1 \%$ AntiINH. & ohne & 110 & 27,5 & 2,6 & $24-30$ & $27,3^{\mathrm{a}}$ & 5,2 & $19-33$ \\
\hline 5 & $9 \% \mathrm{pFF}+1 \%$ AntiINH & Eileiter & 120 & 30,0 & 5,8 & $21-36$ & $50,3^{b}$ & 21,1 & $24-83$ \\
\hline 6 & $9 \% \mathrm{pFF}+1 \%$ AntiINH. & BRL & 108 & 27,0 & 3,7 & $21-31$ & $39,8^{b}$ & 25,8 & $14-67$ \\
\hline 7 & $9 \% \mathrm{pFF}+1 \% \mathrm{ZS}$ ak. & ohne & 119 & 29,8 & 2,5 & $26-33$ & $24,1^{\mathrm{a}}$ & 13,8 & $3-24$ \\
\hline 8 & $9 \% \mathrm{pFF}+1 \% \mathrm{ZS}$ ak. & Eileiter & 116 & 29,0 & 5,0 & $22-36$ & $43,9^{\mathrm{b}}$ & 9,2 & $31-57$ \\
\hline 9 & $9 \% \mathrm{pFF}+1 \% \mathrm{ZS}$ ak. & BRL & 84 & 28,0 & 5,7 & $21-35$ & $49,9^{\mathrm{b}}$ & 2,6 & $48-54$ \\
\hline 10 & ohne & ohne & 124 & 31,0 & 9,1 & $17-42$ & $19,9^{\mathrm{a}}$ & 7,3 & $10-29$ \\
\hline 11 & ohne & Eileiter & 101 & 25,3 & 5,8 & $18-31$ & $54,2^{\mathrm{b}}$ & 20,6 & $29-84$ \\
\hline 12 & ohne & BRL & 111 & 27,8 & 2,7 & 23-30, & $44,2^{\mathrm{b}}$ & 20,6 & $17-65$ \\
\hline
\end{tabular}

Werte mit unterschiedlichen Indices unterscheiden sich signifikant ( $p<0,05$,Tukey`s Studentized Range Test)Anti-INH= gegen Inhibin antikörperhaltiges Ziegenserum ohne Hitzeinaktivierung

ZS ak.= Ziegenserum ohne Antikörper gegen Inhibin ohne Hitzeinaktivierung (Kontrolle) 


\subsection{Einsatz von Eileiter- und BRL Feederlayern in Maturation porciner Oozyten sowie anschließender Kultur der resultierenden Embryonen nach In-vitro-Fertilisation (Versuch 8).}

Für diesen Versuch sind die Ergebnisse der Teilungsrate, der FDA- uns Hoechst A 33342 -Färbung in Tabelle 18 zusammengefaßt. Die besten Teilungergebnisse mit 66\% lieferte Gruppe 1 mit einem BRL-Feederlayer in der Reifung und in der sich anschließenden Kultur nach Befruchtung. Die schlechtesten Teilungsergebnisse (18\%) wurden bei einer Kultur ohne Feeder während Maturation und Kultur (Kontrollgruppe 9) erzielt. Diese Kontrollgruppe 9 zeigte auch die schlechtesten Ergebnisse nach der FDA-Färbung (46\%) und Hoechstfärbung (28\%).

Die Durchschnittsergebnisse der verschiedenen Feederlayer in Maturation und Feederlayern in der Kultur zeigen deutlich signifikante Unterschiede zwischen den Versuchsgruppen. Die Versuchsgruppen 1 bis 3 mit einem BRL-Feederlayer in der Maturation, die Gruppen 4 bis 6 mit pEIL-Feederlayern in der Maturation und die Gruppen 7 bis 9 ohne Feederlayer in der Maturation zeigten jeweils im Durchschnitt Teilungsraten von 51, 43 und 37\%, lebende Embryonen zu 79, 81, und 62 sowie Embryonen mit zwei oder mehr Zellkernen in einer Frequenz von 71, 56 und 41\%. Somit wiederholt sich das zuvor schon ermittelte Ergebnis, daß Gruppen mit einem von beiden der eingesetzten Feederlayer in der Maturation bessere Ergebnisse erzielen als ohne Feederlayer. Bei der Gruppierung nach Feederlayern in der sich anschließenden Kultur wurden folgende Ergebnisse erzielt: Die Gruppen 1, 4 und 7 mit einem BRL-Feeder in der Kultur, 2, 5 und 8 mit pEIL als Feederlayer in der Embryokultur und den Gruppen 3, 6 und 9 ohne eine Kultivierung mit Helferzellen wurden 47, 51 und 29\% Teilungsrate, 79, 74 und 64\% lebendes Zytoplasma und zu 59, 69 und 40\% Embryonen mit zwei oder mehr Zellkernen ermittelt. 
Tabelle 18: Versuch 8: Einfluß von Eileiter- und BRL Feederlayern in sowohl Maturation porciner Oozyten als auch anschließender Kultur der resultierenden Embryonen auf Teilung, Vitalität und Kernzahl (Anzahl Wiederholungen = 4)

\begin{tabular}{|c|c|c|c|c|c|c|c|c|c|c|c|}
\hline \multirow[t]{3}{*}{ Gruppe } & \multirow{3}{*}{$\begin{array}{l}\text { Feederlayer } \\
\text { Maturation }\end{array}$} & \multirow{3}{*}{$\begin{array}{l}\text { während } \\
\text { Kultur }\end{array}$} & \multicolumn{3}{|c|}{$\frac{\text { Anzahl eingesetzter }}{\text { Oozyten }}$} & \multicolumn{2}{|c|}{ Teilungsrate (\%) } & \multicolumn{2}{|c|}{$\frac{\text { lebende Oozyen nach }}{\text { Befruchtung (\%) }}$} & \multirow{2}{*}{\multicolumn{2}{|c|}{$\begin{array}{l}\frac{\text { Oozyten mit zwei }}{\text { oder mehr }} \\
\frac{\text { Zellkernen nach }}{\text { Befruchtung }} \\
\frac{(\%)}{\underline{(0)}}\end{array}$}} \\
\hline & & & \multirow[t]{2}{*}{ Gesamt } & \multirow[t]{2}{*}{$\bar{X}$} & \multirow[t]{2}{*}{$\mathrm{SD}$} & \multirow[t]{2}{*}{$\bar{X}$} & \multirow[t]{2}{*}{$\mathrm{SD}$} & \multirow[t]{2}{*}{$\bar{X}$} & \multirow[t]{2}{*}{ SD } & & \\
\hline & & & & & & & & & & $\bar{X}$ & $\mathrm{SD}$ \\
\hline 1 & BRL & BRL & 72 & 18,0 & 9,0 & $65,6^{\mathrm{a}}$ & 28,6 & $83,7^{\mathrm{a}}$ & 18,9 & $77,9^{\mathrm{a}}$ & 14,2 \\
\hline 2 & BRL & $\mathrm{pEIL}$ & 71 & 17,8 & 8,7 & $55,4^{\mathrm{a}}$ & 16,8 & $85,8^{\mathrm{a}}$ & 15,3 & $74,6^{\mathrm{a}}$ & 19,7 \\
\hline 3 & BRL & ohne Feeder & 68 & 17,0 & 8,3 & $32,6^{b}$ & 16,0 & $66,7^{\mathrm{a}}$ & 9,3 & $60,1^{b}$ & 23,7 \\
\hline 4 & pEIL & BRL & 77 & 19,3 & 3,9 & $44,0^{\mathrm{a}}$ & 24,0 & $78,5^{\mathrm{a}}$ & 20,9 & $61,9^{\mathrm{a}}$ & 11,6 \\
\hline 5 & pEIL & $\mathrm{pEIL}$ & 84 & 21,0 & 6,2 & $47,1^{\mathrm{a}}$ & 10,6 & $84,1^{\mathrm{a}}$ & 19,8 & $74,7^{\mathrm{a}}$ & 8,7 \\
\hline 6 & $\mathrm{pEIL}$ & ohne Feeder & 72 & 18,0 & 7,6 & $38,9^{b}$ & 10,2 & $81,7^{\mathrm{a}}$ & 5,6 & $31,2^{b}$ & 12,9 \\
\hline 7 & ohne Feeder & BRL & 87 & 21,8 & 7,9 & $48,1^{\mathrm{a}}$ & 6,4 & $73,9^{a}$ & 23,5 & $39,7^{\mathrm{a}}$ & 9,1 \\
\hline 8 & ohne Feeder & $\mathrm{pEIL}$ & 75 & 18,8 & 6,3 & $44,3^{\mathrm{a}}$ & 21,6 & $65,8^{a}$ & 14,3 & $59,2^{\mathrm{a}}$ & 16,2 \\
\hline 9 & ohne Feeder & ohne Feeder & 80 & 20,0 & 6,6 & $18,2^{\mathrm{b}}$ & 13,5 & $47,6^{\mathrm{b}}$ & 31,4 & $25,2^{b}$ & 8,4 \\
\hline
\end{tabular}


4.9. Eileiterfeederlayer während der In-vitro Maturation und Kultur porciner Ozyten und Embryonen im Vergleich zu in vivo gereiften und in vitro befruchteten Oozyten und Embryonen auf Eileiterfeederlayern mit anschließendem Embryotransfer auf Empfängersauen (Versuch 9).

Die Ergebnisse dieses Versuches sind in Tabelle 20 aufgeführt.

Im Versuchsansatz ohne Embryotransfer hatten die Versuchsgruppen 1 und 2 einen Eileiterfeeder während der Maturation, in Versuchsgruppe 3 und 4 wurde auf den Feederlayer während der Reifung verzichtet. Oozyten der Gruppen 1 und 3 stand zusätzlich in der Embryonenkultivierung ein Eileiterfeeder zur Verfügung.

Die Kontrollgruppe 4 ohne jeglichen Feederlayer zeigte die besten Teilungsergebnisse (46\%) allerding auch die schlechtesten Ergebnisse bezüglich Vitalität und Kernanzahl (50, 19\%). Gruppe 1 mit Eileiterfeedern in beiden Kulturen zeigte 43\% Teilungsrate, 88\% lebende Oozyten nach der Befruchtung und 56\% der Embryonen wiesen zwei oder mehr Zellkerne auf. Die Gruppen 2 und 3 zeigten Teilungs, Vitalitäts- und Kernzahlen von 32 und $42 \%$, 89 und $73 \%$, sowie 44 und $34 \%$.

Beim Versuchsansatz mit Embryotransfer brachte Versuchsgruppe 1 in vitro gereifter und befruchteter Oozyten am 2. Tag nach der Kultur 29\% geteilte Embryonen im 2-6 Zellstadium auf. Diese Embryonen wurden morphologisch klassifiziert und je Versuchsdurchgang wurden nur die jeweils besten 20 Embryonen pro Empfängersau übertragen. Insgesamt standen 5 Empfängersauen zur Verfügung. Die nicht geteilten 325 Oozyten (71\%) wiesen zu 55\% die Metaphase II auf und zeigten zu 21\% zwein oder mehr Zellkerne, waren also befruchtet (Tabelle 21).

Versuchsgruppe 2 der in vivo gereiften Oozyten zeigte nur 17\% geteilte Embryonen, so daß $83 \%$ der Oozyten gefärbt wurden. Hier wurde nur bei $20 \%$ der Oozyten die Metaphase II nachgewiesen und nur 6\% der Oozyten wiesen zwei oder mehr Zellkerne auf. Die restlichen Oozyten befanden sich in einem früherem Reifungsstadium, wobei allerdings Oozyten das Keimbläschenstadium (GV) verlassen hatten.

Keine der Empfängersauen wurde am 28. Tag nach Embryotransfer mittels Ultraschall tragend befunden. 
Tabelle 20: Versuch 9: Vergleich des Einflusses von Eileiterfeederlayern in der Maturation und Kultur von porcinen Oozyten und Embryonen (Anzahl Wiederholungen = 4)

\begin{tabular}{|c|c|c|c|c|c|c|c|c|c|c|c|}
\hline \multirow[t]{4}{*}{ Gruppe } & \multirow{4}{*}{$\begin{array}{l}\text { Feederlayer } \\
\text { Maturation }\end{array}$} & \multirow{4}{*}{$\begin{array}{c}\text { Feederlayer } \\
\text { Kultur }\end{array}$} & \multirow{2}{*}{\multicolumn{3}{|c|}{$\frac{\text { Anzahl eingesetzer }}{\text { Oozyten }}$}} & \multicolumn{2}{|c|}{$\underline{\text { Teilungsrate }}(\%)$} & \multirow{2}{*}{\multicolumn{2}{|c|}{$\frac{\text { lebende Oozyten nach }}{\underline{\text { Befruchtung (\%) }}}$}} & \multirow{2}{*}{\multicolumn{2}{|c|}{$\begin{array}{l}\text { Oozyten mit zwei oder } \\
\text { mehr Zellkernen nach }\end{array}$}} \\
\hline & & & & & & \multirow{3}{*}{$\bar{X}$} & \multirow{3}{*}{$\mathrm{SD}$} & & & & \\
\hline & & & \multirow{2}{*}{ Gesamt } & \multirow[t]{2}{*}{$\bar{X}$} & \multirow{2}{*}{$\mathrm{SD}$} & & & \multirow[t]{2}{*}{$\bar{X}$} & \multirow[t]{2}{*}{$\mathrm{SD}$} & \multicolumn{2}{|c|}{ Befruchtung (\%) } \\
\hline & & & & & & & & & & $\bar{X}$ & $\mathrm{SD}$ \\
\hline 1 & pEIL & pEIL & 128 & 32,0 & 9,0 & 42,9 & 5,3 & $87,6^{\mathrm{a}}$ & 13,5 & $56,2^{\mathrm{a}}$ & 23,6 \\
\hline 2 & pEIL & ohne Feeder & 129 & 32,3 & 7,7 & 32,2 & 7,2 & $89,1^{\mathrm{a}}$ & 5,5 & $44,1^{\mathrm{a}}$ & 7,8 \\
\hline 3 & ohne Feeder & $\mathrm{pEIL}$ & 130 & 32,5 & 10,3 & 42,2 & 14,3 & $72,8^{\mathrm{b}}$ & 24,7 & $34,0^{b}$ & 11,9 \\
\hline 4 & ohne Feeder & ohne Feeder & 127 & 31,75 & 12,9 & 45,9 & 24,7 & $50,0^{\mathrm{b}}$ & 19,8 & $19,4^{\mathrm{b}}$ & 5,0 \\
\hline
\end{tabular}

Werte mit unterschiedlichen Indices unterscheiden sich signifikant ( $p<0,05$,Tukey`s Studentized Range Test) 
Tabelle 21:Versuch 9: Embryonale Entwicklungsstadien am zweiten Tag nach In-vitro-Kultivierung auf Eileiterfeederlayern aus in vitro maturierten porcinen Oozyten auf Eileiterfeederlayern im Vergleich zu in vivo gereiften Oozyten

\begin{tabular}{|c|c|c|c|c|c|c|c|c|c|c|c|c|c|}
\hline \multirow{3}{*}{$\begin{array}{l}\text { Versuchs- } \\
\text { gruppe }\end{array}$} & \multicolumn{2}{|c|}{ Feederlayer } & \multirow{3}{*}{$\begin{array}{l}\text { Oozyten } \\
\text { gesamt }\end{array}$} & \multirow{2}{*}{\multicolumn{2}{|c|}{$\mathrm{UFO}^{\mathrm{x}}$}} & \multirow{2}{*}{\multicolumn{2}{|c|}{$\begin{array}{c}\text { Geteilte } \\
\text { Embryonen }\end{array}$}} & \multirow{2}{*}{\multicolumn{2}{|c|}{ MII-Oozyten }} & \multirow{2}{*}{\multicolumn{2}{|c|}{$\begin{array}{l}\text { GV-TeloI- } \\
\text { Oozyten }\end{array}$}} & \multirow{2}{*}{\multicolumn{2}{|c|}{$\begin{array}{c}\text { Oozyten mit zwei } \\
\text { oder mehr Zellkernen }\end{array}$}} \\
\hline & Maturation & Kultur & & & & & & & & & & & \\
\hline & & & & $\mathrm{N}$ & $\%$ & $\mathrm{~N}$ & $\%$ & $\mathrm{~N}$ & $\%$ & $\mathrm{~N}$ & $\%$ & $\mathrm{~N}$ & $\%$ \\
\hline \multirow[t]{3}{*}{1} & in vitro & in vitro & 459 & 325 & 70,8 & 134 & 29,1 & 177 & 54,5 & 61 & 18,8 & 68 & 20,9 \\
\hline & $\mathrm{pEIL}$ & $\mathrm{pEIL}$ & & & & & & & & & & & \\
\hline & & in vitro & & & & & & & & & & & \\
\hline 2 & in vivo & $\mathrm{pEIL}$ & 191 & 158 & 82,7 & 33 & 17,3 & 32 & 20,3 & 116 & 73,4 & 10 & 6,3 \\
\hline
\end{tabular}

x: Unbefruchtete Oozyte 


\subsection{Diskussion}

Die In-vitro-Fertilisation ist eine Methode, Embryonen außerhalb eines Muttertieres zu erzeugen. Tierzüchterische Anwendungen wie z.B. die Erhaltung bedrohter Tierrassen, Verminderung deckspezifischer Tierseuchen oder genetische Manipulationen zur Erstellung pharmazeutischer Produkte (,gene pharming“) rechtfertigen die Erstellung von Embryonen in vitro. Das Verfahren der In-vitro-Fertilisation beim Haustier kann auch deshalb interessant sein, weil sich hieraus wertvolle Informationen für spezielle Techniken der In-vitro-Fertilisation beim Menschen ergeben könnten. So ist die Invitro-Maturation humaner Oozyten eine sehr aktuelle Fragestellung bei PCO (PolyCystic-Ovar)-Patientinnen und jungen Frauen mit Ovarialkarcinomen.

Es ist heute durchaus möglich, aus in-vivo-maturierten sowie in vivo-befruchteten Oozyten des Schweines präimplantatorische Embryonalstadien bis zur transferfähigen Blastozyste in vitro weiterzuentwickeln (CHENG, 1986; NAGAI et al., 1988; MATTIOLI et al. 1989; YOSHIDA et al., 1990; ZHENG \& SIRAD, 1992; FUNAHASHI \& DAY, 1993; SINGH \& ARMSTRONG 1994; RATH et al., 1995; WANG et al., 1995). Für ein komplettes porcines In-vitro-Fertilisationsprotokoll stellt die In-vitro Maturation beim Schwein das Schlüsselereignis dar (EDWARDS, 1965; WEIGL \& BREM, 1985; MATTIOLI et al. 1988a, b).

In der vorliegenden Arbeit wurde schwerpunktmäßig die In-vitro-Maturation porciner Oozyten untersucht. Zur Verbesserung der nuklearen Maturationrate wurde ein heterologer Antikörper gegen Inhibin eingesetzt. Weiterhin wurden Feederlayer zum Erhalt der Vitalität der Oozyten und Embryonen getestet.

\subsection{Gewinnung der Ovarien und Oozyten}

Beim Schwein stellt die Gewinnung unreifer Oozyten aus den Ovarien geschlachteter Jungsauen eine kostengünstige und einfache Möglichkeit dar, Gameten für die In-vitroFertilisation zu erhalten.

Die Ovarien vom Schwein fallen am Schlachthof zwar in großer Zahl an, doch muß bedacht werden, daß am Schlachthof die Fleischgewinnung an erster Stelle steht. Die Ovarien werden zusammen mit allen übrigen Innereien aus der Bauchhöhle entfernt, so daß ein Kontakt mit Darminhalt durchaus möglich ist und eine bakterielle Kontaminationsgefahr schon im Vorfeld gegeben ist. Da es sich bei den heutigen Schlachthöfen um EU-Schlachthöfe handelt, sacken die Innereien auf einer separat laufenden Edelstahlrutsche in Richtung Konfiskatkübel. Dieser Weg kann sehr lang 
sein, so daß die Ovarien bis zur Verbringung in den Thermosbehälter Wärme verlieren und starken Temperaturschwankungen ausgesetzt sind.

Dieser Temperatureinfluß kann vor allem im Winterhalbjahr extrem sein, wie die Untersuchungen von NAGAI et al. (1983) bestätigen. YOSHIDA et al. (1993) weisen darauf hin, daß Wärmeverluste während der gesamten Oozytenpräparation vermieden werden müssen.

Eine extreme Schädigung der Oozyten kann durch den Brühprozeß der Sauen erfolgen. Die Tiere werden vor der Eröffnung der Bauchhöhle mit $63-65^{\circ} \mathrm{C}$ heißem Wassser abgebrüht, um Schmutz und Borsten von der Außenhaut entfernen zu können. Eingehende Untersuchungen von SCHLIEPER \& HOLTZ (1986) über den Effekt des Brühprozesses auf die Embryonenqualität mit der Implantanationsrate als biologischen Prüfparameter zeigen deutlich, daß das Brühen einen signifikant negativen Einfluß hat. Die intraperitoneal gemessene Körpertemperatur der Tiere erhöhte sich von der vor der Betäubung ermittelten Rektaltemperatur von $39,6 \pm 0,3 .{ }^{\circ} \mathrm{C}$ um durchschnittlich $1,2^{\circ} \mathrm{C}$ auf $40,8 \pm 0,5^{\circ} \mathrm{C}$. Nach Vergleich zweier verschiedener Gewinnungsverfahren für Embryonen (chirurgisch und post mortem vor und nach dem Brühen) war die chirugische Gewinnungsmethode der Spülung nach Schlachtung und Brühen sowohl in der Gesamtzahl der Feten, der Anzahl normal ausgebildeter Feten als auch der Implantationsrate signifikant überlegen. Durch den Prozeß des Brühens könnten die in den Oozyten vorhandenen Speicherlipide und Membranen zerstört und Chromosomendefekte ausgelöst werden. Dem gegenüber stehen Tierarten, die nicht diesem Brühprozess unterliegen und bei denen die In-vitro-Fertilisation als etabliert gilt (Rind, Schaf, Maus). Möglicherweise werden aus diesem Grund bessere Ergebnisse nach In-vitro-Befruchtung erzielt. MEINECKE et al. (1982) geben bei der Verwendung von Schlachthausmaterial zu bedenken, daß eine Beeinträchtigung der empfindlichen Enzymsysteme, die für die Steroidsekretion verantwortlich sind, nicht ausgeschlossen werden können.

Im Gegensatz zu Schlachthausovarien vom Rind, die oft eine Negativauswahl alter und kranker Tiere darstellen (BERG, 1993), findet man beim Schwein kaum pathologisch veränderte Ovarien, da es sich hier um Masttiere definierten Alters und Gewichts handelt.

Der Zykusstand der als Eizellspender ausgewählten Tiere wurde durch Festlegung der minimalen und maximalen Follikelgröße eingegrenzt, so daß mit einem annährend homogenen Ausgangsmaterial von Oozyten gearbeitet wurde. 
Die Gewinnungsmethode für Oozyten aus Schweineovarien durch das Aufschneiden der Follikel ist optimal, da auf diese Weise die Oozyten aus dem Follikel gewonnen wurden, ohne mechanische Einwirkungen auf die Kumuluszellen auszuüben.

HAMANO \& KUWAYAMA (1993) belegen dieses Ergebnis mit ihren Untersuchungen an Rinderovarien, indem sie die Schneidemethode der Follikelaspiration gegenüberstellen. In Qualität und Quantität konnten die Autoren mittels der Schneidemethode mehr und bessere Oozyten finden. Die Autoren fanden nach der Schneidemethode im Durchschnitt 63,3 Oozyten wobei 84,6\% morphologisch intakt waren, während sie nach der Follikelaspiration im Durchschnitt nur 22,1 Oozyten mit 41,3\% normaler Morphologie fanden.

\subsection{In-vitro-Maturation porciner Oozyten mit einem Antikörper gegen Inhibin, Eileiter- und Buffalo-Rat-Liver - Feederlayern}

Die In-vitro-Reifung (Maturation) von Schweineoozyten war das Hauptziel der vorliegenden Arbeit, da es bis heute bei dieser Technik noch enorme Defizite gibt. So können zwar in isolierten Kumulus-Oozyten-Komplexen meiotische Prozesse eingeleitet werden, die zur Entarretierung des Diktyotän-Stadiums führen, und im besten Fall bis zur Metaphase II ablaufen, aber nicht zum Stadium einer vollständigen Oozytenreife führen. Eine schwache Entwicklungskompetenz der Oozyten läßt sich als eine noch nicht abgeschlossene zytoplasmatische Reifung deuten (WEIGL \& BREM, 1985).

In den eigenen Untersuchungen wurde zuerst der Einfluß von fetalem Kälberserum auf die In-vitro-Maturation von Schweineoozyten untersucht. Diese Versuche zeigten, daß ein Serumzusatz von mindestens 5\% zwingend notwendig ist, um eine nukleare Reifung und eine ausreichend muzifizierte Kumulusexpansion $\mathrm{zu}$ induzieren, daß aber FKS nicht optimal zur Reifung von Schweineoozyten geeignet ist, da eine Maturationsrate von $47 \%$ nicht überschritten wurde. Dieses Ergebnis stimmt mit den Aussagen von NAITO et al. (1988) überein. FUNAHASHI \& DAY (1993) kommen in ihren Untersuchungen sogar zu dem Schluß, daß fetales Kälberserum im Maturationsmedium einen hemmenden Einfluß auf die zytoplasmatische Reifung von Schweineoozyten besitzt, was sie durch eine geringe Anzahl an Vorkernstadien nach IVF dokumentieren. Auch Ziegenserum hatte in der eigenen Untersuchung keine positiven Effekte auf die porcinen Oozyten, denn der Zusatz von $10 \%$ hitzeinaktiviertem Ziegenserum lieferte die schlechtesten Maturationsraten (47\%).

Inhibin wird in vitro von den Granulosazellen sezerniert (ERICKSON \& HSUEH, 1978). HENDERSON \& FRANCHIMONT (1983) belegen dieses, indem sie nach Entfernung 
der Granulosazellen einen 80\%igen Abfall der Inhibin-Produktion feststellten. In der eigenen Untersuchung wurde die In-vitro-Maturation in einem Medium durchgeführt, das mit einem an Ziegenserum gebundenen Antikörper gegen Inhibin supplementiert worden war. Dieses Anti-Inhibin wurde von Inhibin -immunisierten Ziegen gewonnen (HENNIES et al., 1992). Dieser Antikörper sollte freies Inhibin aus der porcinen Follikelflüssigkeit und von den Kumuluszellen der Oozyten abfangen, und so den reifungshemmenden Einfluß des Hypophysenhormones neutralisieren. Im In-vivoModell konnten O`SHEA et al. (1994) sowie GLENNCROSS et al. (1994) zeigen, daß eine Immunisierung gegen Inhibin eine signifikant größere Ovulationsrate beim Schaf induziert. DIETRICH et al. (1995) zeigen am Modell der Ziege, daß eine Immunisierung gegen Inhibin die Follikelzahl erhöht. Das bedeutet, daß durch eine Immunisierung mehr Follikel für die anstehende Ovulation rekrutiert wurden, in denen die Oozyten die Meiose wieder aufnahmen.

Die Versuchsgruppen im zweiten Versuch mit Anti-Inhibin zu 1 und 0,1\% ergaben Reifungsraten porciner Oozyten von 62 und $72 \%$. Die dazuzugehörigen Kontrollversuchsgruppen mit 1 bzw. 0,1\% nicht hitzeinaktiviertem Ziegenserum zeigten hingegen nur 64 und $61 \%$ Oozyten, die die Metaphase II erreicht haben. Hitzeinaktiviertes Ziegenserum hingegen zeigte nur zu 47\% reife Oozyten. Somit kann dem Anti-Inhibin bezüglich der Reifung von porcinen Oozyten eine positive Wirkung zugeschrieben werden, die durch den reifungsreduzierenden Effekt des Ziegenserums an sich herabgesetzt wurde. Die besten Reifungsergebnisse wurden mit reiner porciner Follikelflüssigkeit erreicht (84\%).

Aufgrund dieser Beobachtung wurde versucht die positiven Effekte des Antikörpers gegen Inhibin der porcinen Follikelflüssigkeit zu kombinieren, indem verschiedene Mischungsverhältnisse im Hinblick auf die Maturation untersucht wurden.

In der Literatur gehen die Meinungen über den positiven Effekt von Follikelflüssigkeit auf eine abgeschlossene nukleare und zytoplasmatische Reifung auseinander. Während viele Arbeitsgruppen der Follikelflüssigkeit einen reifungsfördernden Effekt zuschreiben (MATTIOLI et al., 1988; NAITO et al., 1989; YOSHIDA et al., 1993), sprechen andere von einem eher inhibierenden Einfluß (TSAFIRI \& CHANNING, 1975). FUNAHASHI \& DAY (1993) schreiben pFF in der In-vitro-Maturation den Einfluß einer Senkung der Polyspermierate zu. Die angeblich maturationshemmende Wirkungsweise porciner Follikelflüssigkeit wurde erstmals von TSAFIRI \& CHANNING (1975) publiziert.. RACOWSKY \& McGAUGHEY (1982) erklären diese Diskrepanz der Aussagen mit einer Fehlinterpretation der whole-mount-Präparate, die sich bei 
Schweineoozyten durch eine sehr dunkle Anfärbung des lipidhaltigen Dottermaterials darstellen, so daß die Analyse fixierter Präparate sich als nicht einfach gestaltet. Die Autoren folgern, daß das GV-Stadium mit der diploiden MII-Konfiguration verwechselt worden ist und auf diese Weise Fehlinterpretationen der Oozytenreifung entstanden sein müssen die Summe der tatsächlich gereiften Oozyten unterschätzt wurde.

In der Follikelflüssigkeit kleiner Follikel wurden „Oocyte meiotic inhibitor“ (OMI) sowie Inhibin in großen Mengen festgestellt, während diese Inhibitoren in sprungreifen Graafschen Follikeln kaum vertreten waren (VAN DE WIEL, 1983). Im Gegensatz dazu fanden MILLER et al. (1991) in kleinen Follikeln weniger und in größeren Follikeln mit reifen Oozyten mehr Inhibin.

In den eigenen Versuchen wurde davon ausgegangen, daß Inhibin in der Follikelflüssigkeit vorhanden ist, die deshalb mit antikörperhaltigem Ziegenserum im Verhältnis 1:1 gemischt wurde. Allerdings blieb der gewünschte positive Effekt des Anti-Inhibins aus. Beste Ergebnisse bezüglich Maturationsraten lieferte erneut die reine porcine Follikelflüssigkeit und erst das zweitbeste Ergebnis kam aus der Kombination mit antiinhibinhaltigem Ziegenserum. Diese Ergebnisse lassen erneut den Schluß zu, daß der Effekt des Ziegenserums die Reifung der Oozyten behindert und so den positiven Effekt des Anti-Inhibins überdeckt.

Porcine Follikelflüssigkeit im Medium ergibt hohe nukleare Reifungsraten mit guter Kumulusexpansion (LEIBFRIED \& FIRST, 1980; RACOWSKY\& McGAUGHEY, 1982; NAITO et al., 1990; YOSHIDA et al., 1990, 1992; DAEN et al., 1994). Die Ergebnisse dieser Untersuchung zeigen, daß der Einsatz eines hitzeinaktivierten Ziegenserums nicht zu empfehlen ist. Nur ein geringer Anteil der Oozyten reift heran und eine Kumulusexpansion findet nur unzureichend statt. Eine nicht homogene Hyaluronsäureeinlagerung mit einhergehender eingeschränkter Muzifizierung des Kumulus oophorus sind dabei die Regel. Weiterhin kann festgestellt werden, daß der Zusatz des Antikörpers gegen Inhibin inaktiviertes Ziegenserum aufwerten kann, so daß eine tendenzielle Verbesserung der Reifungsrate erreicht wird.

Die Kombination von Follikelflüssigkeit und Anti-Inhibin erbrachte zwar bessere Reifungsraten als Ziegenserum ohne Antikörper, allerdings konnten Reifungsraten wie in Kultur mit reiner Follikelflüssigkeit nicht erreicht werden. Dies macht deutlich, daß der Antikörper gegen Inhibin einerseits positive Effekte auf die nukleare Maturation von Schweineoozyten besitzt, daß andererseits aber durch seine Bindung an Ziegenserum die biologische Aktivität wieder eingeschränkt wird. Konsequenz dieser 
Versuche wäre also, den Antikörper gegen Inhibin an ein neutrales Trägerprotein zu koppeln.

In einem einem weitereren Versuchsansatz wurde der Einfluß von Feederlayern auf die In-vitro-Maturation der Schweineoozyten im Keimbläschen-Stadium überprüft. Ein gravierender Unterschied in der In-vitro-Maturation von Schweineoozyten zu der anderer Säugetieren ist die Notwendigkeit der langen Verweildauer der Oozyten im Maturationsmedium. Die Maturationsphase von Oozyten des Schweines ist mit 44-48h zweimal länger als die von Wiederkäuern und dreimal länger als die von Nagetieren (MOTLIK et al., 1986).

MATTIOLI (1994) vermutet, daß während dieser lang andauernden Kulturphase eine Erschöpfung der Nährstoffe im Medium und eine Anreicherung mit toxischen Stoffwechselprodukten der kultivierten Zellen stattfindet. Er vermutet weiterhin, daß die unreifen Oozyten des Schweines nicht ausreichend „Maturation promoting factor“ (MPF) akkumuliert haben und so eine Brechung der nuklearen Membran zur Vorkernbildung nur schwer stattfinden kann.

Die unreife Oozyte des Schweines benötigt zur Maturation beispielsweise bestimmte Lipide (HOMA et al., 1986). Fette übernehmen nicht nur bei der Ernährung der Zellen wichtige Funktionen, sondern haben auch einen potentiellen Effekt bei Zell-Zell Interaktionen, sowie die Erhaltung physikalischer Eigenschaften und Funktionen biologischer Membranen (STUBBS \& SMITH, 1984).

Die dargestellten Probleme der besonderen Ansprüche von Schweineoozyten sollten in den vorliegenden Versuchen durch den Einsatz zweier Feederlayertypen, nämlich Eileiter- und BRL-Feederlayer gelöst werden. Sie sollten ein Nährstoffspektrum liefern, das den Oozyten sowohl in qualitativer als auch in quantitativer Weise gerecht wird. Feederlayer aus Eileiterzellen sezernieren Hyaluronsäure (MIYANO et al., 1994), die sich nach Untersuchungen von ARCHIBONG et al. (1989) günstig auf die Entwicklung von Schweinezygoten bis zur Blastozyste erwiesen hat. GANDOLFI (1994) weist darauf hin, daß in der Eileiterflüssigkeit identifizierbare Mengen an „Epidermal-growth factor“ (EGF) vorgefunden werden, der dem Epithel entstammt. Weiterhin werden Glycin und Taurin, die am meisten im Ovidukt vorkommenden freien Aminosäuren, sezerniert. Sie agieren als Osmolyte und schützen die Embryonen vor osmotischem Streß, indem sie die $\mathrm{H}^{+}$-Konzentrationen konstant halten.

Zwar läßt sich in vitro eine gute Kumulusexpansion erzeugen, die auf eine abgeschlossene Kern- und Zytoplasmareifung hindeutet (MOTLIK et al., 1986), doch treten schlechte Befruchtungsraten mit hohen Polyspermieraten auf. Bei erfolgter 
Kumulusexpansion muß gewährleistet sein, daß die Reinitiierung der Meiose nicht überstürzt passiert. Das bedeutet, daß ein inniger Kontakt zwischen Kumulus und Oozyte bis zur Metaphase I erhalten bleiben muß (MOTLIK et al., 1986). Deshalb sollen die für die In-vitro-Maturation eingesetzten Medien zwar der Follikelflüssigkeit ähneln, aber eine vorzeitige Reinitiierung der Meiose verhindern (GÖTZE et al., 1990).

Durch die 3x4 faktorielle Versuchsanstellung wurde erstmals der Effekt von Feederlayern in Kombination mit verschiedenen Proteinzusätzen im Medium bei der Invitro-Maturation von Schweineoozyten überprüft.

Es wurde ein deutlich positiver Effekt von beiden Feederlayertypen beobachtet. Weiterhin vermag der Einsatz eines Feederlayers eine Serumkomponente vollständig zu ersetzten. Allerdings konnte kein fördernder Effekt von Anti-Inhibin festgestellt werden und so kam es in weiteren Untersuchungen nicht mehr zum Einsatz.

Zur Überprüfung der nuklearen Reifung von Oozyten wurden die Chromosomen mit Hilfe verschiedener Techniken dargestellt. Zum einen kam in dieser Arbeit die Giemsa Färbung zur Anwendung. Mittels dieser ist es möglich, Metaphase II-Chromosomen deutlich darzustellen. Allerdings ist die Auswertungsrate sehr niedrig (TARKOWSKI, 1966). Es handelt sich dabei um eine Chromosomenspreizung, bei der die durch Natriumcitrat aufgeblähte Oozyte mit Hilfe von Essigsäure zum Platzen gebracht wird. Nach Ausschwemmung der Chromosomen und Trocknung werden diese durch den Giemsa-Farbstoff gefärbt. Es geschieht leider sehr häufig, daß sich der Chromosomensatz so weit von seiner zugehörigen Oozyte entfernt, daß er nicht mehr zugeordnet werden kann.

Die Lacmoid-Färbung hat deshalb die Giemsa-Methode in dieser Arbeit abgelöst. Hier betrug die Wiederfindungsrate der gefärbten Oozyten 100\%. Durch das Auftragen zweier etwa $3 \mathrm{~mm}$ breiter Paraffin - Vaseline (9:1) Streifen wurde das Deckglas fixiert, um während der langen Verweildauer im Essigsäure-Alkohol-Gemisch (1:3) nicht abgespült zu werden. MALENKO (1994) tritt diesem Problem durch die Konstruktion einer feuchten Färbekammer entgegen. Sowohl bei MALENKO (1994) als auch in dieser Arbeit konnten alle Stadien der Meiose vom germinalen Vesikel über „Germinal vesicle breakdown“(GVBD), Prometaphase I, Metaphase I, Anaphase I, Telophase I und Metaphase II genauestens dokumentiert werden. So konnte geklärt werden, ob innerhalb einer Kultur wenigstens die Meiose wieder aufgenommen wurde, oder ob der Arrest im GV-Stadium erhalten blieb. Nachteil der Lacmoid-Methode war, daß ein Zeitraum von mindestens 24 Stunden Fixierung in Essigsäure-Alkohol eingehalten 
werden mußte. Dies war bei der Giemsa-Metode nicht notwendig, da die Präparate sofort nach Fixierung gefärbt und beurteilt werden konnten.

\subsection{In-vitro-Entwicklung in vitro gereifter und befruchteter Oozyten}

$\mathrm{Da}$ das Erreichen der nuklearen Reife einer Oozyte nur den halben Weg zur Befruchtung darstellt, mußte die zytoplasmatische Reife ebenfalls untersucht werden. Die zytoplasmatische Reifung der Oozyten kann nicht mit einer Färbung nachgewiesen werden, sondern wurde durch eine In-vitro-Fertilisation der Oozyten überprüft. So wurden die Oozyten der Versuche 3, 4 und 5 mittels Lacmoid-Färbung auf ihre nukleare Reife untersucht. Die Versuchsanstellungen wurden in den Versuchen 6, 7 und 8 beibehalten, und mit neuen Oozyten besetzt, um Aussagen über die zytoplasmatische Reifung durch Befruchtungsversuche herauszuarbeiten.

Zwar nur tendentiell, aber dennoch unübersehbar brachten Versuchsgruppen mit dem Zusatz von hitzeinaktiviertem Ziegenserum trotz schlechterer Maturationsraten bessere Befruchtungsergebnisse. Somit konnten in Gruppen mit nicht hitzeinaktivierten Ziegenseren nahezu 50\% der Oozyten auch befruchtet werden. Die Ergebnisse lassen die Vermutung zu, daß im nicht hitzeinaktivierten Ziegenserum embryotrophe Stoffe vorhanden sind (z.B.. Transferrin, Fibronectin), welche die frühembryonale Entwicklung fördern. Die nukleare Maturation einer Oozyte könnte möglicherweise durch die von CHANG (1949) postulierten ovoziden Faktoren eingeschränkt werden. Auch BARG (1994) überprüfte die Entwicklungsrate von Mäuseembryonen, die in einem Medium kultiviert wurden, das mit einem nicht hitzeinaktiviertem Serum supplementiert worden war. Sie bestätigte die Ergebnisse von CHANG (1949) und stellt eine verminderte Entwicklungsrate und -geschwindigkeit der Embryonen fest. Die Ergebnisse dieser Arbeit lassen den Schluß zu, daß mit der Zugabe des nicht inaktivierten Serum von Ziegen eine Art Selektion der Oozyten stattfindet, denn von den maturierten Oozyten konnten dann $50 \%$ befruchtet werden.

Auch PINYOPUMINTR \& BAVISTER (1994b) stellen in ihren Untersuchungen an Rinderembryonen fest, daß eine Hitzeinaktivierung von Blutseren nicht notwendig ist. Durch die unterlassene Inaktivierung bleiben embryotrophe Eigenschaften im Serum erhalten. Die Autoren vermuten sogar eine Entwicklung von eher embryotoxischen Substanzen durch die Hitzeinaktivierung des Serums. Ebenso können TODOROV et al. (1993) keine Hitzeinaktivierung rechtfertigen, denn in ihren Untersuchungen mit 
östrischem Kuhserum fand eine reduzierte Entwicklung der Rinderembryonen in hitzeinaktiviertem Medium statt.

Follikelflüssigkeit hatte in den eigenen Untersuchungen zwar äußerst reifungsfördernde Fähigkeiten, allerdings waren die Befruchtungszahlen tendentiell schlechter als in den mit Anti-Inhibin oder aktivem Ziegenserum kultivierten Gruppen. Es muß also in Einklang mit den oben genannten Autoren davon ausgegangen werden, daß durch die unterlassene Hitzeinaktivierung Proteinstrukturen im Serum erhalten blieben, die die in-vitro gereiften Oozyten mit embryotrophen Faktoren unterstützten.

Das Wirkungsspektrum an Nährstoffen und Wachstumsfaktoren, die endokrin, parakrin und autokrin auf die Oozyten Einfluß haben, wurde durch den Einsatz von Eileiter- und BRL-Feederlayern zusätzlich zu den Proteinquellen erweitert. Die zu maturierenden Oozyten konnten in den eigenen Versuchen in einem qualitativ und in quantitativ angepaßten Wirkungsspektrum während der langen Kulturphase optimal ernährt werden. Beispielsweise bestätigen IM \& PARK (1995) einen positiven Effekt auf Embryonenentwicklungen von Wachstumsfaktoren wie Epidermal growth factor (EGF), der von Eileiterfeedern sezerniert wird.

Der Eileiterfeeder in Kombination mit der porcinen Follikelflüssigkeit stellt ein Milieu dar, das den In-vivo-Bedingungen während Ovuluation und Befruchtung in der Ampulle eines Säugetieres am nächsten kommt und deshalb auch sehr gute Reifungs- und Befruchtungserfolge im 5. und 8. Versuch dieser Arbeit ermöglichte. Es wird vermutet, daß der Feederlayer in der Lage ist, als Osmoregulator zu agieren (NAGAO et al., 1994; SPINDLE, 1995). KANO et al. (1994) und PAVASUTHIPAISIT et al. (1994) erörtern, daß Oviduktzellen einen löslichen Faktor besitzen, der eine verbesserte Embryonalentwicklung ermöglicht. Dieser Faktor ist nicht Spezies-spezifisch, denn die Autoren setzten zur Kultur von Rinderembryonen die Zellen des Eileiters vom Schwein ein. Das Schwein gehört zu den mehr-gebärenden Tieren, so daß die Hypothese aufgestellt wurde, daß die Zellen vom Schweineeileiter eine besonders hohe Potenz an wachstumsfördenden Faktern sezernieren (KANO et al., 1994; PAVASUTHIPAISIT et al., 1994).

WISEMAN et al. (1992) finden große Mengen von den Wachstumsfaktoren IGF I und II in der Oviduktflüssigkeit vom Schwein, so daß die Feederzellen dieser Tierspezies auch ein Medium mit den Faktoren anreichern müßten. Schon WHITE et al. (1989) stellten durch den Einsatz von Eileiterfeederlayern eine verbesserte embryonale Entwicklung von frühe Embryonen beim Schwein fest. Leider wurden die spezifischen embryotrophen Faktoren noch nicht beschrieben. BRL-Feederlayer konnten sich ebenfalls in der 
Embryokultivierung etablieren und angemessene Embryoentwicklungsraten bei Rinderembryonen hervorbringen (VOELKEL \& HU, 1992). Die Wirkungsweise der Feederlayer ist bis heute nicht vollständig geklärt. So postulieren NAKAO \& NAKATSUJI (1990), daß lediglich der Kontakt der Embryonen mit den Feederzellen einen ebenso wirkungsvollen Effekt besitzt wie die von den Zellen sezernierten Faktoren. Aus den vorliegenden Daten wird deutlich, daß beide Feederlayer in der Lage sind, das Serum als Proteinquelle im Medium zu ersetzen, was auch Untersuchungen von DUNFORD \& STUBBINGS (1992) und KATSKA et al. (1995) ergaben. Die Ergebnisse dieser Arbeit zeigen auch, daß mindestens eine Proteinquelle in Form von Feederlayern oder Serumzusatz vorhanden sein, um akzeptable Ergebnisse zu erzielen. Bei der Entscheidung für den Einsatz eines Feederlayers im Kultursystem muß der Mehraufwand für die Zellkultur bedacht werden. Dabei zeigten die eigenen Untersuchungen deulich, daß es schwieriger war durch das Spülen von Eileitern Zellen $\mathrm{zu}$ gewinnen und in einer Anzuchtkultur keimfrei zu passagieren, als kommerziell erhältliche BRL-Zellen für die Feederkultur zu benutzen.

REHMANN et al. (1994) erzielten bei Rinderembryonen mit der Kokultur aus etablierten BRL-Zellen, die ein konstantes Faktorenspektrum sezernieren, bessere Ergebnisse als mit Eileiterfeedern. Die Arbeitsgruppe von VAN INZEN et al. (1995) stellten die Problematik der Überwucherung der kultivierten Embryonen mit nicht inaktivierten Feederlayerzellen in ihren System fest, was natürlich die Entwicklung der Embryonen behinderte. Aus diesen Gründen sind die Autoren zu konditionierten Medien übergegangen, daß heißt sie benutzten nur den aus einer Feederlayerkultur angereicherten Medienüberstand. Innerhalb dieser Arbeit konnten diese Überwucherungen nicht festgestellt werde, obwohl auch mit nicht inaktivierten Feederlayern gearbeitet wurde. Einer Inaktivierung von Feederlayern geht eine Mitomycinbehandlung des Zellrasens voraus, um die Mitoserate der kultivierten Feederzellen zu stoppen. Das Mitomycin wird durch Waschen der Kultur nach einer gewissen Einwirkdauer zwar wieder entfernt, doch könnten noch immer Spuren des Mitosehemmers vorhanden sein, so daß aus diesem Grund in der vorliegenden Untersuchung auf diese Methode verzichtet wurde.

Weiterhin wurde in dieser Arbeit die These aufgestellt, daß nur aktive, lebende Zellen in der Lage sind, kontinuierlich Faktoren $\mathrm{zu}$ sezernieren und toxische Stoffwechsekprodukte zu eliminieren, um so dem In-vivo-System näher zu kommen. Der lebende Organismus ist durch eine kontinuierliche Fluktuation von endokrinen, 
parakrinen und autokrinen Faktoren charakterisiert, so daß die Dynamik in den vorliegenden Untersuchungen im In-vitro-Modell simuliert werden sollte.

In dieser Arbeit wurde ein Arbeitsprotokoll zur Gewinnung von Eileiterzellen erstellt (Kap. 3.9.1.), mit dem es möglich ist, mindestens 50\% der erhaltenen Eileiterkulturen auch keimfrei zu passasgieren. Für einen routinemäßigen Einsatz von Feederzellen sollten BRL-Zellen eingesetzt werden, da sich die Ergebnisse nur unwesentlich von denen der Eileiterkulturen unterschieden und in der Handhabung wesentlich einfacher sind. Allerdings muß bedacht werden, daß eine Kokultur zwar eine geeignete Methode darstellt, daß sie aber auch eine sehr undefinierte Kulturtechnik ist. Die sezernierten Inhaltsstoffe in den Medien von Kokulturen sind unbekannt und varieren wahscheinlich von einer Kultur zur anderen (PEURA, 1993)

Nachdem Feederkulturen in der vorliegenden Arbeit bei der In-vitro-Maturation eingesetzt wurden, kamen sie weiterhin in der sich anschließenden Embryokultur zum Einsatz. Das Nährstoffspektrum, an das sich die Oozyten in der sehr langen Maturationsphase adaptiert hatten, wurde in der Kultur beibehalten. Es zeigte sich, daß es besser ist, ein homogenes Feederspektrum in der Reifung und anschließenden Kultur anzubieten, d.h. beispielsweise Eileiterfeederlayer in der Maturation und Embryonenkultivierung. Sehr ungünstig wirkte sich ein Abbruch des Feedersystems nach der Maturationsphase aus, wie die Ergebnisse deutlich hervorbringen. Die Oozyten sind nach der Maturation auf einem hohen Nährstoffniveau, welches dann in einer nicht feedergestützten Kultur nicht mehr erreicht wurde und die Entwicklungsraten drastisch reduzierte.

Grundvoraussetztungen in allen Versuchsreihen war eine hohe Qualität der Kulturmedien. So wurden die Maturationsmedien neben hormonellen und energetisch wichtigen Bestandteilen mit einem Insulin-Transferrin-Selenit Komplex supplementiert. In der Kulturphase wurde ein von PETTERS \& REED (1991) sowie TORRES \&RATH (1992) propagiertes NCSU 23 Medium benutzt, welches sich gerade für die In-vitro-Entwicklung von Schweineembryonen als sehr förderlich herausgestellt hat. Die Autoren berichten, daß es nur in diesem Medium möglich ist, Blastozysten zum Schlüpfen zu bringen. Es enthält unter anderem Taurin. Diese Schwefel-enthaltende ßAminosäure ist in vielen Säugetiergeweben enthalten (LIU et al., 1995; RATH et al. 1995) und in der Lage, H+-Ionen abzufangen und so intrazellulär stabilisierend zu wirken. 


\subsection{Beurteilungskriterien porciner Embryonen}

Da eine morphologische Beurteilung von Embryonen zwangsläufig subjektiv sein muß, wurde jeder einzelne Embryo zusätzlich mittels fluoreszenzmikroskopischer Untersuchungen klassifiziert. Das bedeutet, daß jeder Embryo der einzelnen Versuchsgruppen zuerst morphologisch klassifiziert wurde, danach wurde Vitalitätsüberprüfung des Zytoplasmas (FDA) (SCHILLING \& DÖPKE, 1979) durchgeführt und anschließend am Embryo Nachweise morphologisch intakter Kerne (Hoechst A 33342) vollzogen, so daß ein Embryo gleichzeitig drei Aussagen liefern konnte . Die Hoechst-Färbung wird auch von PURSEL et al. (1985) und VIUFF et al. (1991) propagiert und als eine schnelle sowie einfache Methode herausgestellt, um eine nukleare Entwicklung von Embryonen zu dokumentieren. WURTH et al. (1994) hat einen mitotischen Index zur Qualitätskontrolle von Rinderembryonen benutzt. Die Blastomerenanzahl sollte möglichst hoch mit der Anzahl festgestellter Kerne korreliert sein.

In allen Versuchsgruppen traten hohe Frequenzen von Oozyten mit einem lebenden, also vitalen Zytoplasma auf, was sich durch eine hell-grün fluoreszierende Färbung manifestierte. Die Gruppe mit 10\% pFF und dem Eileiterfeeder in Maturation und Kultur brachte $97 \%$ vitale Oozyten hervor, so daß die Vermutung nahe liegt, die physiologischen In-vivo-Bedingungen mittels der vorliegenden Kulturen geschaffen zu haben. Es wurde aus der morphologischen Beurteilung des Embryos, sowie der Beurteilung des Blastomerenzytoplasmas deutlich, daß diese Parameter keinen sicheren Nachweis für einen lebenden Embryo darstellten. Erst die dritte sich anschließende Färbeuntersuchung der Kerndarstellung vermochte deutlich signifikante Unterschiede zwischen den Versuchsgruppen aufzuzeigen. Die Kernfärbung zeigte die Embryonen an, die mehr als einen morphologisch intakten Kern besaßen. Es muß dabei bedacht werden, daß Oozyten im Vorkernstadium auch zwei Kerne besitzen, nämlich einen männlichen und einen weiblichen Vorkern. Diese Oozyten gelten als penetriert, sind aber morphologisch keine als Zweizeller. So gestalten sich die Ergebnisse in dieser Arbeit derart, daß die Zahl der angefärbten und identifizierten Kerne oft höher ist, als die Anahl der Blastomerenzahl der Embryonen. Deshalb sind in den Ergebnissen dieser Arbeit die Kernzahlen höher als die Anzahl der Blastomeren der gefundenen Embryonen.

Auch in der 8. Untersuchung zeigte sich, daß Feederlayer-unterstützte Kulturen signifikant bessere Ergebnisse lieferten als herkömmliche Kulturen ohne Feederlayer. 
In einer abschließenden Untersuchung wurden in-vivo gereifte Oozyten in-vitro gereiften Oozyten gegenübergestellt. Beide Eizelltypen wurden in vitro befruchtet und kultiviert und anschließend auf Empfängersauen übertragen. In beiden Versuchsgruppen traten keine Trächtigkeiten. Es wird vermutet, daß die Anzahl der übertragenen Embryonen zu gering war, da man sich an Transferversuche mit in-vivo erzeugten Embryonen gehalten hat, wo nur bis zu 18 Embryonen übertragen werden. Das Schwein benötigt bis zum 15. Trächtigkeitstag das Signal von mindestens 4 intakten Embryonen, um die Trächtigkeit aufrecht zu erhalten (POLGE et al., 1966, DZIUK, 1968). Die Embryonen aus der In-vitro-Kultur sind allem Anschein nach nicht so vital, was sich durch eine geringere Anzahl nachweisbarer Kerne sowie einer reduzierten Induzierung von Trächtigkeiten äußert (TORRES \& RATH, 1992; RATH et al., 1995) und müssen deshalb in sehr großer Zahl in den Eileiter der Sau transferiert werden. Von YOSHIDA (1987) wurde beschrieben, daß nach In-vivo-Reifung und Invitro-Befruchtung porciner Oozyten der Transfer von nur 17 Zweizellern in den Eileiter einer synchronisierten Empfängersau einen Wurf von 4 Ferkeln ergab. Spätere Untersuchungen von YOSHIDA et al.(1990) beschäftigten sich dann mit In-vitro maturierten Oozyten. Hier wurden 190 geteilte Embryonen auf 4 Empfänger übertragen (47,5 Embryonen/Tier). Nach erneuter Spülung der Uterushörner nach 7 Tagen konnten 9\% der Embryonen als Blastozyste wiedergewonnen werden. Die Zahl transferierter Embryonen pro Empfängertier wurde hier also drastisch gesteigert. Trotzdem war die Zahl sich entwickelnder Embryonen eher gering. Ob eine Trächtigkeit bis zur Geburt weitergelaufen wäre, bleibt offen. 1993 teilten YOSHIDA et al. mit, daß nach Transfer von 75 Embryonen auf einen Empfänger aus einer In-vitro Maturation 3 gesunde Ferkel hervorgegangen sind. 4\% der übertragenen Embryonen haben sich also zu Ferkeln entwickeln können. MATTIOLI et al. (1989) konnten nach Transfer von 40-50 Embryonen pro Empfänger ebenfalls 2 Trächtigkeiten erzeugen.

VAJTA et al., 1991 konnten nach Transfer von 20-24 Embryonen aus einer In-vitroMaturation eine Trächtigkeit erzeugen, die aber nur per Ultraschall nachgewiesen wurde.

Schlußfolgernd läßt sich zusammenfassen, daß Anti-Inhibin in der hier dargebrachten Form nur einen tendentiellen positiven Effekt auf die In-vitro-Maturation von Schweineoozyten besitzt. Signifikant positive Effekte können aber dem Feederlayer sowohl in der Maturation als auch bei der Kultur von porcinen Zellen zugesprochen werden. Dabei sollte dem BRL-Feederlayer der Vorzug gegeben werden, da dieser in Konstanz der Sezernierung des Wirkungsspektrums und der Handhabung besser sind. 
Weiterhin hat sich in der Klassifizierung der Schweineembryonen eine parallele Anwendung der Hoechst A 33342- und FDA-Färbung nach vorhergehender morphologioschen Klassifizierung als vorteilhaft erwiesen. Der letztendliche Beweis der Vitalität der porcinen Embryonen konnte innerhalb dieser Arbeit nicht geliefert werden. Die Oozyten aus der In-vivo-Maturation ergaben innerhalb dieser Forschungsarbeit ebenfalls keine Trächtigkeit. Es muß an dieser Stelle wieder bedacht werden, daß die Eizellspender wie die Schlachtsauen auch erst gebrüht wurden und dann die Oozytenentnahme stattfand, um den In-vitro maturierten Oozyten keine Sonderbehandlung zu geben. Die eingangs diskutierten Probleme, die sich durch diese Entnahmetechnik ergeben, sollten an dieser Stellen nocheinmal berücksichtigt werden. Abschließend ist $\mathrm{zu}$ bemerken, daß das herkömmliche Reifungssytem für Schweineoozyten mit reiner porciner Follikelflüssigkeit durch die in den Experimenten dieser Arbeit mit Feederlayern und Serum supplementierten Medien bezüglich der Teilungsrate, sowie Vitalität der Embryonen eine deutliche Verbesserung hervorbrachte. Da es sich in den angestellten Versuchen um ein Screening mit einer hohen Anzahl an Versuchsgruppen handelte, sind die erhaltenen Ergebnisse in der Anzahl entwickelter Embryonen wahrscheinlich etwas reduziert. Die erhöhte Arbeitszeit außerhalb des Brutschranks und somit eines sehr variablen Klimamilieus schränkt die Entwicklungsfähigkeit der Embryonen stark ein. Gerade beim Schwein spielt dieser Aspekt eine sehr große Rolle, wie aus der Arbeit von BLUM (1989) deutlich hervorgeht. 


\subsection{Zusammenfassung}

In den vorliegenden Untersuchungen wurden Methoden erarbeitet, um bei porcinen Oozyten sowohl eine nukleare als auch eine synchron ablaufende zytoplasmatische Reifung zu erreichen. Zum einen wurden dazu unterschiedliche Seren und porcine Follikelflüssigkeit eingesetzt. Einen Schwerpunkt bildet hierbei der Einsatz eines an Ziegenserum gekoppelten Antikörpers gegen das reifungshemmende Hormon Inhibin. Weiterhin wurden Feederlayersysteme getestet, sowohl um Oozyten zu reifen als auch befruchtete Oozyten zu kultivieren.

Die Oozyten wurden aus den Ovarien geschlachteter peripuberaler Jungsauen durch Aufschneiden der Follikel gewonnen und nach dreimaligem Waschen in PBS $+10 \%$ FKS in ein Maturationsmedium (TCM199 + Proteinquelle/Feederlayer) überführt. Die Maturation der Oozyten wurde im Brutschrank bei $39^{\circ} \mathrm{C}$ unter $5 \% \mathrm{CO}_{2}$ für 46 Stunden durchgeführt. In den Versuchen 1 bis 4 wurde die Anzahl der Metaphase II-Oozyten (Maturationsrate) bestimmt. Dabei wurde in Versuchen 1 und 2 die GiemsaFärbetechnik angewendet und zusätzlich der Expansionsgrad des muzifizierten Kumulus oophorus nach der Reifung beurteilt. In den Versuchen 3 und 4 wurde die Giemsa-Färbung von der Lacmoid - Färbung abgelöst. In den Versuchen 5 bis 9 wurden die in vitro gereiften Oozyten fertilisiert, um auch die zytoplasmatische Reifung der Oozyten zu überprüfen. In diesen Versuchen wurde neben der Teilungsrate auch die Integrität des Zytoplasmas der Blastomeren (FDA-Färbung) sowie die Anzahl der embryonalen Zellkerne (Hoechst A 33342 -Färbung) bestimmt.

Im ersten Versuch ( $n=192-258$ Oozyten/Gruppe) wurde der Einfluß unterschiedlicher Konzentrationen fetalen Kälberserums (FKS) auf die Maturationsrate von porcinen Oozyten überprüft. Es stellte sich heraus, daß ein Zusatz von 5\% FKS zum MaturationsBasismedium TCM199 mit einer 48\%igen Maturationsrate und 47\% vorzüglichen expandierten Kumuli die empfehlenswerte Konzentration darstellte. Der Zusatz von 1\% FKS erzielt zwar tendenziell höhere Reifungsraten (50\%), jedoch wurden nur 23\% der Oozyten mit einem vorzüglich expandierten Kumulus oophorus eingestuft.

Der allgemein übliche Zusatz von 10\% FKS zum Maturationsmedium erzielte nur mittelmäßige Erfolge (39\% Reifungsrate, 23\% Oozyten der Qualität I). Die Unerläßlichkeit eines Serumzusatzes wurde in diesem Versuch durch die erste Versuchsgruppe bestätigt, denn hier wurden bei Fehlen eines Serumzusatzes nur 27\% Metaphase II-Oozyten mit 17\% vorzüglich expandierten Kumuli festgestellt. 
Im zweiten Versuch ( $\mathrm{n}=162-307$ Oozyten/Gruppe) wurde der Effekt eines Inhibinantikörperhaltigen Ziegenserums auf die Maturation der porcinen Oozyten untersucht. Die Kontrollgruppe mit $10 \%$ porciner Follikelflüssigkeit zeigte die besten Reifungsergebnisse sowohl bezüglich der Maturationsrate als auch der Expansion des Kumulus oophorus (83 und 87\%). Anti-inhibinhaltige Maturationsmedien waren gegenüber den Gruppen ohne Inhibin mit 61 und $70 \%$ gegenüber 64 und $61 \%$ tendenziell überlegen. Ein Kontroll - Ziegenserum ohne Inhibinantikörper, jedoch Hitze-inaktiviert, lieferte die deutlich schlechtesten Reifungsergebnisse (47\%), so daß dem Zusatz des Inhibin-Antikörpers ein reifungsfördernder Effekt zugeschrieben werden konnte.

Der dritte Versuch ( $n=61-86$ Oozyten/Gruppe) beschäftigte sich erneut mit unterschiedlichen Konzentrationen inhibinantikörperhaltigen Ziegenserums, wobei hier porcine Follikelflüssigkeit und nicht wie in Versuch 2 hitzeinaktiviertes Ziegenserum die Basis-Proteinquelle darstellte. Antikörperhaltige Medien waren bezüglich der Maturationsrate gegenüber den Medien ohne Antikörper det Tendenz nach überlegen (71, 71und $65 \%$ gegenüber 58, 67 und $68 \%$ ).

In Versuch $4 \quad(\mathrm{n}=74-116$ Oozyten/Gruppe $)$ wurde mit 12 verschiedenen Versuchsgruppen neben einem Serumeffekt zusätzlich der Einfluß von zwei Feederlayerkomponenten auf die In-vitro-Maturation porciner Oozyten überprüft. Alle Versuchsgruppen mit einem Feederlayer in der Reifungsphase (Buffalo-Rat-LiverZellen, BRL oder Eileiterfeederlayer, pEIL; Gruppe 2, 3, 5, 6, 8, 9 swie 11 und 12) waren gegenüber den Versuchsansätzen ohne Feederlayer signifikant überlegen. Das beste Maturationsergebnis mit $88 \%$ MII-Ozyten wurde mit $10 \%$ pFF und BRL-Feederlayer erzielt, während nur 40\% Metaphase II-Oozyten in einem Medium ohne Serum/pFF und ohne Feederlayer bestimmt wurden. Die Versuchsgruppen mit antikörperhaltigem Ziegenserum und pEIL oder BRL Feederlayern waren den Gruppen mit nicht hitzeinaktiviertem Ziegenserum und pEIL oder BRL der Tendenz nach wiederum übelegen (81\%, 78\% gegenüber 74\%, 70\%). Die Versuchsgruppen 11 und 12 mit BRL oder pEIL ohne Serum oder porcine Follikelflüssigkeit lieferten dennoch Reifungsraten von jeweils 79\%, womit deutlich wurde, daß ein Feederlayer die Funktion eines Serums in der In-vitro-Kultur ersetzten konnte.

Zur Überprüfung der zytoplasmatischen Maturation wurden Oozyten in Versuch 5 in vitro fertilisiert und die Teilungsrate bestimmt und nicht bereits nach der Reifung angefärbt ( $n=109-139$ Oozyten/Gruppe). Die Versuchsgruppen wurden mit neuen Oozyten besetzt, gereift und befruchtet, ohne die Versuchsgrupenanstellung von Versuch 3 zu ändern. Die in Versuch 3 zuvor schlechter abschneidenden 
Versuchsgruppen ohne Antikörper gegen Inhibin zeigten in dieser Versuchsserie die tendenziell höchste Teilungsrate von 32, 32 und 34\%. Auch die Medien mit geringeren Konzentrationen Anti-Inhibin zeigten diese Teilungsrate während die niedrigste Teilungsrate im Medium mit $10 \% \mathrm{pFF}$ festgestellt wurde (25\%), welches im Maturationsversuch die höchste Maturationsrate gezeigt hatte. Aufgrund dieser vergleichenden Versuchsanstellung ergab sich eine große Diskrepanz zwischen nuklaer und zytoplasmatisch reifungsfördenden Eigenschaften von Medienzusätzen.

Im 6. Versuch ( $n=158-220$ Oozyten/Gruppe) wurde die zytoplasmatische Reifung der Oozyten überprüft, die zusätzlich mit einem Feederlayer in der Maturation kultiviert wurden, so daß die Versuchsanstellung der des 4. Versuches entsprach. Bestes Ergebnis der Teilungsrate lieferte eine Kultur mit 9\% pFF, $1 \%$ Anti-Inhibin sowie einem BRLFeederlayer (38\%), schlechtestes Ergebnis (21\% Teilungsrate) eine Kultur ohne Proteinquelle und Feederlayer. Die Teilungsraten aller übrigen Versuchsgruppen lagen zwischen 25 und $32 \%$.

In Versuch 7 ( $n=84-137$ Oozyten/Gruppe) wurde ein komplexes Beurteilungsystem zur Klassifizierung der Versuchsgruppen angewendet: Es wurde bei jeder Oozyte die Teilungsrate, die Integrität des Zytoplasmas sowie die Anzahl der Zellkerne nach Invitro-Fertilisation bestimmt. Die Versuchsanstellung wurde entsprechend Versuch 6 angeordnet. Bei allen drei Beurteilungskriterien schnitten die Versuchsgruppen ohne Feederlayer gegenüber denen mit einem Feederlayer schlechter ab. Eine KultivierungsKonstellation von 9\% pFF, 1\% Anti-Inhibin und einem BRL-Feederlayer lieferte hinsichtlich der Merkmale Teilungsrate, Vitalität und Zellkernzahl mit 39, 89 und 40\% die besten Ergebnisse. Kulturen mit 9\% pFF, 1\% Anti-Inhibin und Eileiter-Feederlayern zeigten eine Teilungsrate von 35\%, 94\% vitale Oozyten und 50\% befruchtete Oozyten mit zwei und mehr Zellkernen. Diese beiden Kultivierungsmöglichkeiten können daher zur Maturation porciner Oozyten empfohlen werden.

Versuch 8 ( $n=68-80$ Oozyten/Gruppe) berücksichtigte den Einsatz eines Feederlayers sowohl in der Maturationsphase als auch in der anschließenden Kulturphase der Embryonen. Ein kombiniertes Feederlayersystem mit BRL-Zellen in beiden Kulturphasen erbrachte die besten Ergebnisse mit 66\% Teilungsrate, $84 \%$ vitalen Oozyten und 78\% Oozyten mit zwei und mehr Zellkernen gegenüber Maturations- und Embryonenkultur ohne jeglichen Feederlayer (18\% Teilungsrate, 48\% lebende Oozyten, 25\% Oozyten mit zwei und mehr Zellkernen). Alle Kulturen bei denen in der Embryokulturphase auf einen Feederlayer verzichtet wurde, schnitten in allen drei Beurteilungsmerkmalen gegenüber Feederlayer-unterstützten Embryokulturen 
signifikant schlechter ab. Der Einsatz von Feederlayern in beiden Phasen der Kultivierung von in vitro maturierten und fertilisierten Oozyten konnte innerhalb dieser Arbeit als positiv herausgestellt werden.

In Versuch 9 ( $n=127-130$ Oozyten/Gruppe) sollten in vitro gereifte mit in vivo gereiften Oozyten verglichen werden. Unreife Oozyten wurden in vitro auf Eileiterfeederlayern gereift und anschließend kultiviert. Gereifte Oozyten wurden von superovulierten Spendersauen gewonnen. Der Erfolg der verschiedenen Reifungssysteme wurde mit Embryotransfer überprüft, nachdem beide Oozytengruppen in vitro befruchtet, und die entstandenden Embryonen auf synchronisierte Empfängertiere übertragen wurden. Es konnte aus keiner Versuchsgruppe eine Trächtigkeit etabliert werden. 


\subsection{Summary}

The present investigation was undertaken in order to develop a method that would result in a synchronous in vitro maturation of nucleus and cytoplasm of porcine oocytes. A series of nine experiments was set up to compare various types and combinations of sera and porcine follicular fluid ( $\mathrm{pFF}$ ). A further important investigative feature was the testing of the use of a goat serum antibody against the maturationinhibiting hormone inhibin. In addition, two feeder layer systems were tested as to their suitability for the in vitro maturation of porcine oocytes and their in vitro cultivation when fertilised.

The oocytes were harvested by cutting open ovarian follicles of slaughtered peripubertal sows. They were washed three times in PBS $+10 \%$ foetal calf serum (FCS) and subsequently transferred to a maturation medium (TCM199 + Protein source/Feeder layer), where they were incubated at $39^{\circ} \mathrm{C}$ and $5 \% \mathrm{CO}_{2}$ for 46 hours. In Experiments 1 4 , the percentage of metaphase II oocytes that developed was determined (maturation rate). In Experiments 1 and 2, the cultured oocytes were stained with Giemsa and the degree of expansion of the mucified cumulus oopherus after maturation was assessed. The Giemsa stain was replaced by Lacmoid stain in Experiments 3 and 4 . In Experiments 5 - 9, the oocytes matured in vitro were fertilised in order to ascertain the efficiency of their cytoplasmic maturation. In these latter five experiments, both the rate of cellular division and the integrity of the blastomeres' cytoplasm were investigated (FDA staining). Also, the number of zygotes containing two or more embryonal nuclei were counted (Hoechst A 33342 staining).

In the first experiment of this series, the influence of different concentrations of FCS on the maturation rate of porcine oocytes was tested ( $n=192-258$ oocytes/group). From the results of this experiment, the recommended concentration of FCS needed to be added to the basic maturation medium (TCM199) was found to be $5 \%$ as this resulted in the best maturation rate (48\%), and an optimally expanded cumulus (quality 1) in $47 \%$ of the oocytes. A slightly higher degree of maturation (50\%) tended to be present when just $1 \%$ FCS was added, but only $23 \%$ of the oocytes had an optimal expansion of their cumulus oophorus.

The generally used standard of adding 10\% FCS to the maturation medium provided only middling success ( $39 \%$ maturation rate, $23 \%$ quality I oocytes). The fundamental 
necessity of FCS in the maturation medium was also confirmed by the results from the first test group where no FCS was present: just 27\% metaphase II oocytes developed and only $17 \%$ had an optimally expanded cumulus.

Experiment 2 looked at the effects of an inhibin-antibody-containing goat serum on the maturation of porcine oocytes ( $n=162-307$ oocytes/group). The first control group grown with only $10 \% \mathrm{pFF}$ showed the best degree of maturation both with respect to the rate of maturation and the expansion of the cumulus oopherus (83\% and 87\%, resp.). The groups of oocytes grown in maturation media containing anti-inhibin antibodies did not grow so well as those with $\mathrm{pFF}$, but they tended to grow better than those groups without this antibody (61\% and $70 \%$ vs $64 \%$ and $61 \%$, resp.). As a second control group grown with a heat-inactivated goat serum without the anti-inhibin antibodies resulted in the poorest results (47\% maturation rate). It can be concluded that the addition of the anti-inhibin antibody promotes maturationof porcine oocytes

The third experiment ( $\mathrm{n}=61-86$ oocytes/group) looked anew at the use of various concentrations of the anti-inhibin goat serum, whereby in this series $\mathrm{pFF}$ was used as the basic protein source and not, as in Experiment 2, the heat-inactivated goat serum. All three media containing the anti-inhibin antibody tended to have better maturation rates than the three media without this antibody (71\%, $71 \%$ and $65 \%$ vs $58 \%, 67 \%$ and $68 \%$, resp.).

In Experiment 4, twelve different test groups ( $\mathrm{n}=74$ - 116 oocytes/group) were set up in order to test not only the effect of differing serum concentrations, but also the influence of two feeder-layer combinations on the in vitro maturation of porcine oocytes. All the test groups with a feeder layer [Buffalo Rat Liver cells (BRL) or porcine oviduct feeder layer (pEIL); Groups 2,3,5,6,8,9,11 and 12] showed significantly better degrees of maturation than the test groups without feeder layers (Groups 1,4,7,10). The best maturation results were attained with $10 \% \mathrm{pFF}$ and a BRL feeder layer (88\% metaphase II oocytes), where less than half of these developed in the culture media without serum/pFF and a feeder layer (40\% metaphase II oocytes). The test groups with both the antibody-containing goat serum and pEIL or BRL tended to grow better than those groups with the non-heat-inactivated goat serum and a pEIL or BRL feeder layer ( $81 \%$ and $78 \%$ vs $74 \%$ and $70 \%$, resp.). Maturation rates of $79 \%$ were achieved in the test groups 11 and 12 grown with BRL or pEIL but without serum or pFF, which shows that a feeder layer can replace the function of serum in in vitro culture.

In order to test their degree of cytoplasmic maturation, the oocytes in Experiment 5 were not stained directly after maturation but were fertilised in vitro and their rate of 
division was determined ( $\mathrm{n}=109$ - 139 oocytes/group). Using the same test situation as in Experiment 3, more oocytes were matured and fertilised. Those test groups without the anti-inhibin antibody which had shown a poor result in Experiment 3 showed in this new test series a tendency for a higher rate of division (32\%, 32\% and 34\%). Those oocytes grown on media with the lowest concentrations of anti-inhibin exhibited an equivalent rate of division to this. In comparison, the group which had exhibited the highest maturation rate in Experiment 3 - the group grown on the medium containing only $10 \%$ pFF - now showed the lowest rate of division (25\%). As the test situation for these two experiments were the same, this result indicates that there is a great discrepancy between the degree of nuclear and cytoplasmic maturation induced by the various additives to the basic culture medium.

The degree of cytoplasmic maturation of the oocytes was then assessed in Experiment 6 ( $n=158-220$ oocytes/group). The test situations in this experiment, whereby the oocytes were cultured with a feeder layer mirrored those set up in experiment 4 . The best rates of division occurred in the culture with $9 \% \mathrm{pFF}, 1 \%$ anti-inhibin and a BRL feeder layer (38\%). The worst results occurred in the culture without either a protein source or a feeder layer. The rate of division of all the other test groups lay between 25 and $32 \%$.

In Experiment 7, a complex system of judgement for the classification of the test groups was used ( $n=84-137$ oocytes/group). The rate of division, the integrity of the cytoplasm and the number of nuclei after in vitro fertilisation were assessed for every oocyte. The design of this experiment was the same as for Experiment 6 . The worst results for all three criteria were found in those test groups without a feeder layer. A cultivation constellation of $9 \% \mathrm{pFF}, 1 \%$ anti-inhibin and a BRL feeder layer produced the best results for the rate of division, vitality and the percentage of zygotes with 2 or more nuclei (39\%, 89\% and 40\%, resp.). The cultures with $9 \%$ pFF, $1 \%$ anti-inhibin and pEIL had a $35 \%$ rate of division, $94 \%$ vital oocytes and $50 \%$ fertilised oocytes containing 2 or more nuclei. These two methods of cultivation can both, therefore, be recommended for the in vitro maturation of porcine oocytes.

Experiment 8 considered the use of a feeder layer not only for the maturation phase but also for the subsequent culture of the embryo ( $n=68-80$ oocytes/group). The best results in both culture phases were obtained with a BRL feeder layer system (66\% division rate, $84 \%$ vital oocytes and $78 \%$ oocytes with 2 or more nuclei). In comparison, the maturation and embryo cultures without feeder layers exhibited a rate of division of $18 \%, 48 \%$ vital oocytes, and $25 \%$ oocytes with 2 or more nuclei. As in comparison to the feeder-layersupported embryo cultures, there were significantly poorer results for all three 
parameters in those cultures where a feeder layer was not used during the embryonal culture phase, it may be concluded that within the scope of this research work, feeder layers have a positive effect on both these phases of oocyte cultivation.

In Experiment 9, in vitro matured oocytes were compared with in vivo matured oocytes ( $\mathrm{n}=127-130$ oocytes/group). The immature oocytes were matured in vitro on oviduct feeder layers and then cultivated, while the mature oocytes were collected from superovulated sows. The success of the different maturation systems were then tested by embryo transfer. The mature oocytes in each group were fertilised in vitro and the resulting embryos were implanted in synchronised recipient sows. A viable pregnancy could not be produced in any of the test groups. 


\subsection{Literaturverzeichnis}

ABE, S. N.HORI, M. HIRAYAMA, T. NAGAI (1994):

Effects of casein phosphopeptides and $\mathrm{Ca}^{2+}$ on in vitro fertilization in vitro of bovine oocytes matured in culture.

Theriogenology $\underline{41}, 151$.

ABEYDEERA, L. R., B. N. DAY (1997):

Fertilization and subsequent development in vitro of pig oocytes in a tris-bufferd medium with frowzen-thawed ejaculated spermatozoa.

Biol. Reprod. 57, 729-734.

ABEYDEERA, L. R., L. A. JOHNSON, G. R. WELCH, W. H. WANG, A. C. BOQUEST,

T. C. CANTLEY, A. RIEKE, B. N. DAY (1998):

Birth of piglets for gender following in vitro fertilization of in vitro matured pig oocytes by $\mathrm{X}$ and $\mathrm{Y}$ chromosome bearing spermatozoa sorted by high speed flow cytometry.

Theriogenology $\underline{50}, 981-988$.

ALBERTS, B., D. BRAY, J. LEWIS, M. RAFF, K. ROBERTS, J. D. WATSON (1990):

Molekularbiologie der Zelle.

VCH Verlagsgesellschaft mbH, Weinheim.

ANDERSON, E., D. F. ALBERTINI (1976):

Gap junctions between the oocyte and companion follicle cells in the mammalian ovary.

J. Cell Biology $\underline{71}, 680-686$.

ARCHIBONG, E. A., R. M. PETTERS, B. H. JOHNSON (1989):

Development of porcine embryos from one- and two cell stages to blastocysts in culture medium supplemented with porcine oviductual fluid.

Biol. Reprod. $\underline{41}, 1076-1083$. 
ARELlANO, J., M. J. ILLERA, P. LORENZO, J. SANCHEZ. G. SILVÁN. J. C. ILLERA, M. ILLEA, R. M. PETTERS (1993):

Epidermal growth factor enhance porcine oocyte maturation in vitro in the absence of follicular fluid or hormones.

Theriogenology $\underline{39}, 180$.

AUSTIN, C. R. (1951):

Observation on the penetration of the sperm into the mammalian egg.

Austr. J. Sci. Res. (B) $\underline{4}, 581-597$.

AUSTIN, C. R. (1960):

Capacitation and release of hyaluronidase from spermatozoa.

J. Reprod. Fert. 1 , 310-311.

AUSTIN, C. R. (1975):

Membrane fusion events in fertilization.

J. Reprod. Fert. 44 , 155-166.

AX, R. L., J. RYAN (1979):

The porcine ovarian follicle. IV. Mucopolysaccarides at different stages of development.

Biol. Reprod. 20, 1123-1132.

BACHVAROVA,R., V. DE LEON ( 1977):

Changes in total RNA, polyadenylated RNA, actin mRNA during meiotic maturation of mouse oocytes.

Develop. Biol.108, 325-331.

BACHVAROVA, R., V. DE LÉON, A. JOHNSON, G. KAPLAN, B. V. PAYNTON (1985):

Changes in total RNA, polyadenylated RNA, actin mRNA during meiotic maturation of mouse oocytes. Stored and polysomal ribosomes in mouse ova.

Develop. Biol. $\underline{58}, 248-254$. 
BALL, G. O., M. L. LEIBFRIED, R. W. JENZ, R. L. AX, B. D. BAVISTER, N. L. FIRST (1983):

Factors affecting successful in vitro fertilization of bovine follicular oocytes.

Biol. Reprod.28, 717-725.

BAMBA, K., Y. KOJIMA (1978):

Evaluation of boar sperm motility by caffeine-slide.

Jpn. J. Anim. Reprod. 24, 100-104.

BARG, CH. K. (1994):

Einfluß der Seruminaktivierung und Mediumerneuerung auf die in vitroEntwicklung von Embryonen.

Diplomarbeit der Agrarwissenschaften an der Georg-August-Universität, Göttingen.

BARNES,F. L., W. H. EYESTONE (1990):

Early cleavage and maternal zygotic transition in bovine embryos.

Theriogenology $\underline{33}, 141-152$.

BAVISTER, B. D. (1988):

Role of oviductal secretions in embryonic growth in vivo and in vitro.

Theriogenology 29 (1), 143-154.

BAVISTER, B. D. (1992):

Co-culture for embryo development: Is it really necessary?

Hum. Reprod. 7, 1339-1341.

BECKMANN, L. S. (1991):

Culture of early-stage porcine embryo.

Ph.D. Dissertation, University of Missouri, Columbia, 1991.

BEDFORD, J. M. (1983):

Form and function of eutherian spermatozoa in relation of the nature of egg investments.In: Fertilization of the human egg in vitro, pp. 133-146, H.M. Beier, H. R. L. Lindner (eds.), Springer Verlag, Berlin Heidelberg. 
BEHBOODI, E., G. B. ANDERSON, R. H. BONDURANT, S. L. CARGILL, B. R. KREUSCHER, J. F. MEDRANO, J. D. MURRAY (1995):

Birth of large calves that developed from in vitro-derived bovine embryos.

Theriogenology $\underline{44}, 226-323$.

BEIER, H. M. (1992):

Fertilisation und Furchung: Eine Kaskade molekularer und zellulärer Reaktionen.

Horme $\underline{2}, 17-28$.

BERG, U. (1993):

Entwicklung präimplantiver Embryonalstadien beim Rind durch in vitro Reifung, Fertilisation und Kultur von Oozyten.

Dissertation, München.

BETANCOURT, M., R. FIERRO, D. AMBRIZ (1993):

In vitro fertilization of pig oocytes matured in vitro.

Theriogenology $\underline{40}, 1155-1160$.

BETTERIDGE, K. J., J. FLÉCHON (1988):

Anatomy and physiology of pre-attachement bovine embryos.

Theriogenology 29, 155-187.

BICSAK, T. A., E. M. TUCKER, S. CAPPEL, J. VAUGHAN, J. RIVIER, W. VALE, A. L. W. HSUEH (1986):

Hormonal regulation of granulosa cell inhibin biosynthesis.

Endocrinology $\underline{119}$ (6), 2711-2719.

BLEIL, J.D., P. M. WASSARMAN (1980):

Synthethis of zona pellucida proteins by denuded and follicle enclosed mouse oocytes during culture in vitro.

Proc. Nat. Acad. Sci. USA 77, 1029-1033. 
BLUM-RECKOW, B., W. HOLTZ (1992)

Transfer of porcine embryos after 3 days of in vitro culture.

J. Anim. Sci. $\underline{69}, 3335-3342$.

BLUM, B. (1989)

Dissertation der landwirtschaftlichen Fakultät der Georg-August-Universität Göttingen.

BOICE, M. L., R. D. GEISERT, R. M. BLAIR, H. G. VERHAGE (1990):

Identification and characterization of bovine oviductual glycoproteins synthesized at estrous.

Biol. Reprod. $\underline{43}$, 457-465.

BOICE, M. L. P., A. MAVROGIANIS, C. N. MURPHY, R. S. PRATHER, B. N. DAY (1992):

Immunocytochemical analysis of the association of bovine oviduct specific glycoproteins with early embryos.

J. Exp. Zool. 263, 225-229.

BONGSO, A., S. C. NG, H. SATHANANTHAN, N. POH LIAN, M. RAUFF, S. RATNAM (1989):

Improved quality of human embryos when cultured with human ampullary cells.

Human Reprod. $\underline{4}$, 706-712.

BÖTTCHER, M., S. BLOTTNER, S. KRÜGER, B. RETTIG, W. LANGE (1990):

Der Einfluß des Cumulus oophorus auf die Befruchtung in vitro gereifter Oozyten des Rindes.

Arch. Exp. Vet. Med. $\underline{44}, 53-57$.

BÖTTCHER, M., B. KLUGE, K. TOMALAK, E. MEYER, W. LANGE (1992):

Zur Wirkung von Follikelflüssigkeit auf die Befruchtung in vitro gereifter Oozyten des Rindes.

Zuchthyg.27, 101-111. 
CANIPARI, R., F. PALOMBI, M. RIMINUCCI, F. MANGIA ( 1984):

Early programming of maturation competence in mouse oogenesis.

Develop. Biol. 102, 519-524.

CARNEY, E. W., C. TOBBACK, R. H. FOOTE (1990):

Co-culture of rabbit one-cell embryos with rabbit oviduct epithelial cells.

In vitro Cell. Dev. Biol. $\underline{26}$, 629-635.

CHANG, M: C. (1949):

Effects of heterologous sera on fertilized rabbit ova.

J. Gen. Phys. $\underline{32}$, 291-300.

CHANG, M. C. (1951):

Fertilization capacity of spermatozoa deposited in the fallopian tubes.

Nature $\underline{168}, 459-461$.

CHANG, M. C. (1955a):

The maturation of rabbit oocytes in culture and their maturation, activation, fertilization and subsequent development in the fallopian tubes.

J. Exp. Zool. 128, 379.

CHANG, M. C. (1955b):

Fertilization and normal development of follicular oocytes in the rabbit.

Science $\underline{121}, 867$.

CHANG, M. C. (1969):

Hormonal regulation of sperm capacitation. In: Schering symposium on mechanisms involved in conception.

Adv.Biosci., $\underline{4}$, 13-24, G. RASPÉ (ed.) Pergamon press, New York

CHANG, S. C. S., J. D. JONES, R. D. ELLEFSON, R. J. RYAN (1976):

The porcine ovarian Follicle: I. Selected chemical analysis of follicular fluid at different developmental stages.

Biol. Reprod. 15, 321-328. 
CHEN, 1., S. E. WERT, E. M. HENDRIX, P. T. RUSSEL, M. CANNON, W. J. LARSEN (1990):

Hyaluronic acid synthesis and gap junction endocytosis are necessary for normal expansion of the cumulus mass.

Mol. Reprod. Dev. 26, 236-247.

CHOI, Y. H., S. SAITO, N. OGURI (1995):

In vitro development of porcine oocytes fertilized in vitro with spermatozoa preincubated in two diffrent media.

Theriogenology $\underline{44}, 287-294$.

COX, J. F. (1991):

Effect of cumulus on in vitro fertilization of in vitro matured cow and sheep oocytes.

Theriogenology $\underline{35}$ (1), 191.

CRABTREE, H. G. (1929):

Observations of the carbohydrate metabolism of tumours.

Biochem. J. 233, 536-545.

CRAN, D. G., W. T. K. CHENG (1985):

Changes in cortical granules during porcine oocyte maturation.

Gam: Res: 11, 311-319.

CRAN, D. G., W. T. K. CHENG (1986):

The cortical reaction in pig oocytes during in vivo and in vitro fertilization.

Gam. Res. 13, 241-251.

CYERT, M. S., M. W. KIRSCHNER (1988):

Regulation of MPF activity in vitro.

Cell $\underline{53}, 185-195$. 
DAEN, F. P., E. SATO, K. NAITO, Y. TOYODA (1994):

The effect of pig follicular fluid fractions on cumulus expansion and male pronucleus formation in porcine oocytes matured and fertilized in vitro.

J. Reprod. Fert. 101, 667-673.

DAVIS, B. K. (1981):

Timing of fertilization in mammals:Sperm-cholesterol/phospholipid ratio as determinant of capacitation interval.

Proc. Natl. Acad. Sci. USA 78, 7560-7664.

DAVIS, D. L. (1985):

Culture and storage of pig embryos.

J. Reprod. Fert. $\underline{33}$ Suppl., 115-124

DAVIS, D. L., B. .L. DAY (1978):

Cleavage and blastocyst formation by pig eggs in vitro.

J. of Anim. Sci. $\underline{46}$ (4), 1043-1053.

De JONG, F. H., R. M. SHARP (1976):

Evidence for inhibin-like activity in bovine follicular fluid.

Nature (London), $\underline{263}, 71-72$.

DIAMOND, M. P., B. W. WEBSTER, R. K. CARR, A. C. WENTZ, K. G. OSTEEN (1985):

Human follicular fluid insulin concentration.

J. Clin. Endocrinol. Metab. $\underline{61}, 990$.

DIELEMAN, S. J., T. A. M KRUIP, P: FONTIJNE, W. H. R De JONG, G. C. WEYDEN, (1983):

Changes in oestradiol, progesterone, and testosterone concentrations in the follicular fluid and the micromorphology of preovulatory bovine follicles relative to the peak of luteinizing hormone.

J. Endocrinol. 97, 31-42, 1983. 
DIETRICH, E., M. HENNIES, J. K. VOGLMAYR, W. HOLTZ (1993):

Ovarian activity and immune response in boer goats treated with recombinant human inhibin $\alpha$-subunit.

Proc. $12^{\text {th }}$ intern. Congr. Anim. Reprod., The Hague,Netherlands, August 23-27, 1993, Communication 345, 1201-1203.

DIETRICH, E., M. HENNIES, W. HOLTZ, J. K. VOGLMAYR (1995):

Immunization of goats against recombinant human inhibin $\alpha$-subunit: Effects on inhibin binding, mating behaviour, ovarian activity and embryo yield.

Anm. Reprod. Sci. 39, 119-128.

DIDION, B. A., D. POMP, M. J. MARTIN, G. E. HOMANICS, C. L. MARKERT (1990):

Observation on the cooling and cryopreservation of pig oocytes at the germinal vesicle stage.

J. Anim. Sci. $\underline{68}, 2803-2810$.

DING, J., G. R. FOXCROFT (1992):

Follicular heterogeneity and oocyte maturation in vitro in pigs.

Biol. Reprod. 푸, 648-655.

DING, J., N. CLARKE, T. NAGAI, R. M. MOOR (1992a):

Protein and nuclear changes in pig eggs at fertilization.

Mol. Reprod. Dev.르, 287-296.

DING, J., R. M. MOOR, G. R. FOXCROFT (1992b):

Effect of protein synthesis on maturation, sperm penetration, and pronuclear development in porcine oocytes.

Mol. Reprod. Dev. 33, 59-66.

DING, J., G. R. FOXCROFT (1994):

FSH-stimulated follicular secretions enhance oocyte maturation in pigs. Theriogenology $\underline{41}$, 1473-1481. 
DORRINGTON, J. H., J. H. BENDELL, A. CHUMA, D. K. LOBB (1987):

Actions of growth factors in the follicle.

J. Steroid. Biochem. 27, 405-411.

DOWNS, S. M., DANIEL, S. A. J., EPPIG J. J. (1988):

Induction of maturation in cumulus cell-enclosed mouse oocytes by folliclestimulating hormone and epidermal growth factor: evidence for a positive stimulus of somatic cell origin.

J. Exp. Zool. 245, 86-96.

DULAK, N. C. H. M. TEMIN (1973):

A particial purified polypeptide fraction from rat liver cell conditioned medium with mutiplication-stimulating activity for embryo fibroblast.

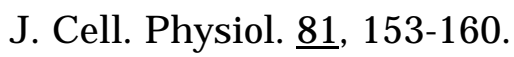

DULBECCO, R., M. VOGT (1953):

Plaque formation and isolation of pure lines with poliomyelitis viruses.

J. Exp. Med. 99, 167-182.

DUMOULIN, J. C. M., J. L. H. EVERS, M. BRAS, M. H. E. C. PIETERS, J. P. M. GERAEDTS (1992):

Positive effect of taurine on preimplantation development of mouse embryos in vitro.

J. Reprod. Fert. 94, 373-380.

DUNBAR, B. S., S. AVERY, V. LEE, S. PRASAD, D. SCHAHN, E. SCHWOEBEL, S. SKINNER, B. WILKINS (1994):

The mammalian zona pellucida: ist biochemistry, Immunochemistry, molecular biology, and developmental expression.

Reprod. Fert. Dev. $\underline{6}, 331-347$.

DUNFORD, R. R. B. STUBBINGS (1992):

The influence of serum and oviductual cells during in vitro maturation on blastocyst development.

Theriogenology 37, 205. 
DZIUK, P. J. (1968):

Effect of number of embryos and uterine space on embryo survival in the pig.

J. Anim. Sci. 27, 673-676.

EBERHARDT, D. M., D. M. HENDRICKS, J. F. DICKEY, J. R. DIEHL (1994):

Oviductal fluid and growth factors failed to enhance development of porcine embryos.

Theriogenology $\underline{41}, 1163-1172$.

EDWARDS, R, G. (1965):

Maturation in vitro of mouse, sheep, cow, pig, Rhesus monkey, and human ovarian oocytes.

Nature 208, 349-351.

EDWARDS, R, G. (1974):

Follicular fluid.

J. Reprod. Fert. 37, 189-219.

ENG, L. A., E. T. KORNEGAY, J. HUNTINGTON, T. WELLMAN (1986):

Effects of incubation temperature and bicarbonate on maturation of pig oocytes in vitro.

J. Reprod. Fert. $\underline{76}, 657-662$.

EPPIG, J. J. (1979a):

A comparision between oocyte growth in coculture with granulosa cells and oocytes with granulosa cell - oocyte junctional contact maintained in vitro.

J. Exp. Zool. 209, 345-353.

EPPIG, J. J. (1979b):

FSH stimulates hyaluronic acid synthesis by oocyte - cumulus cell complexes from moue preovulatory follicles.

Nature $\underline{281}, 483-485$. 
EPPIG, J. J. (1980):

Regulation of cumulus oophorus expansion by gonadotropins in vivo and in vitro.

Biol. Reprod 23, 545-552.

EPPIG, J. J., A. C. SCHROEDER (1986):

Culture systems for mammalian oocyte development: Progress and prospects.

Theriogenology 25 (1), 97-106.

EPPIG, J. J., S. M. DOWNS (1988):

Gonadotropin - induced murine oocyte maturation in vivo is not associated wirth decreased cyclic adenosine monophosphate in the oocyte - cumulus cell complex. Gam. Res. 20, 125-131.

EPPIG, J.J. (1991):

Intercommunication between mammalian oocytes and companion somatic cells.

BioAssays 13, 569-574.

ERICKSON, G. F., A. J. W. HSUEH (1978):

Secretion of „inhibin“ by rat granulosa cells in vitro.

Endocrinology 103 (5), 1960-1963.

EVANS , T., E. T. ROSENTHAL, J. YOUNGBLOM, D. DISTEL, T. HUNT (1983):

Cyclin: a protein specified by maternal $\mathrm{m}$ RNA in sea urchin eggs that is destroyed at each cleavage division. Cell 33, 389-396.

FINDLAY, J. K., D. M. ROBERTSON, I. J. CLARKE, R. KLEIN, B. W. DOUGHTON, S. XIAD. L. RUSSELL, L. SHUKOVSKI (1992):

Hormonal regulation of reproduction - general concepts.

Anim. Reprod. Sci._28, 319-328. 
FINDLAY, J. K. (1993):

An update on the roles of inhibin, activin, and follistatin as local regulatos of folliculogenesis.

Biol. Reprod. $\underline{48}$, 15-23.

FINDLAY, J. K., S. XIAO, S. SHUKOVHKI, U. MICHEL (1993):

Novel peptides in ovarian physiology: Inhibin, activin and follistatin.

In: „The ovary“ (Eds E. Y. ADASHI und P. C. K. LEUNG) pp. 413-432. (Raven Press: New York.)

FINDLAY J. K. (1994):

Peripheral and local Regulators of folliculogenesis.

Reprod. Fert. Dev. $\underline{6}, 127-139$.

FIRST, N. L., PARRISH, J. J. (1987):

In-vitro fertilization of ruminants.

J. Reprod. Fert., Suppl. 34, 151-165.

FLOOD, M. R., J. L. WIEBOLD (1988):

Glucose metabolism by preimplantation pig embryos.

J. Reprod. Fert. $\underline{84}$, 7-12.

FRASER, L. R. (1979):

Accelerated mouse sperm penetration in vitro in the presence of caffeine.

J. Reprod. Fert. 푸, 377-384.

FULKA, J., N. OUHIBI, R. M. MOOR, J. FULKA (1994):

Nuclear transplantation in mammals: The role of maturation promoting factor (MPF).

Reprod. Dom. Anim. 29, 352-378.

FUNAHASHI, H., B. N. DAY (1993):

Effects of the duration of exposure to hormone supplements on cytoplasmic maturation of pig oocytes in vitro.

J. Reprod. Fert. 98, 179-185. 
FUNAHASHI, H., T. T. STUMPF, S. L. TERLOUW, T. C. CANTLEY, A. RIEKE, B. N. DAY (1994a):

Development ability of porcine oocytes matured and fertilized in vitro.

Theriogenology $\underline{41}, 1425-1433$.

FUNAHASHI, H., T. C. CANTLEY, T. T. STUMPF, S. L. TERLOUW, B. N. DAY (1994b):

Use of low-salt culture medium for in vitro maturation of porcine oocytes is associated with elevated oocyte gluthadione levels and enhanced male pronuclear formation after in vitro fertilization.

Biol. Reprod. 푸, 633-639.

FUNAHASHI, H., T. C. CANTLEY, B. N. DAY (1994c):

Different hormonal requirements of porcine oocytes during maturation in vitro.

J. Reprod. Fertil. 101, 159-165.

GANDOLFI, F. R. M. MOOR (1987):

Stimulation of early embryonic development in the sheep by co-culture with ovicuct epithelial cells.

J. Reprod. Fert. $\underline{81}, 23-28$.

GANDOLFI, F., T. A. L: BREVIVI, S. MODINA, R. BIANCHI, L. PASSONI (1993):

Role of the oviduct during early embryogenesis.

Zuchthyg. $\underline{28}$ (4), 189-192.

GANDOLFI, F. (1994):

Autocrine, paracrine and environmental factors influencing embryonic development from zygote to blastocyst.

Theriogenology $\underline{41}, 95-100$.

GARBERS, D. L., N. L. FIRST, S. K. GORMAN, H. A. LARDY (1973):

The effects of cyclic nucleotide phosphodiesterase inhibitors on ejaculated porcine spermatozoan metabolism.

Biol. Reprod. $\underline{8}$, 599-606. 
GARDNER, H. G., KAYE, P. L. (1991):

Insulin in creases cell numbers and morphological development in mouse preimplantation embryos in vitro.

Reprod. Fert. Dev. $\underline{3}$, 79-92.

GERENA, R. L., KILLIAN, G. J. (1990):

Electrophoretic characterization of proteins in oviduct fluid of cows during the estrous cycle.

J.Exp. Zool. 256, 113-120.

GILULA, N. B., M. L. EPSTEIN, W. H. BEERS (1978):

Cell - to - cell communication and ovulation. A study of the cumulus oocyte complex.

J. of Cell Biol. $\underline{78}$, 58-75.

GLENCROSS, R. G., C. L. BLEACH, S. C. WOOD, P. G. KNIGHT (1994):

Active immunization of heifers against inhibin: effects oon plasma concentrations of gonadotrophins, steroids and ovarian follicular dynamics during prostaglandin-synchronized cycles.

J. Reprod. Fert. 100, 599-605.

GÖTZE, M., P. Kaufhold, A. Schuffenhauer, H. Torner, M Spitschak (1990):

Untersuchungen zur Hemmung der Meiose von Rindeoozyten mittels biologischer und synthetischer Inhibitoren.

Arch. Exper. Vet. Med. $\underline{44}, 19-27$.

GOSDEN, R. G., R. H. F. HUNTER (1988):

Electrophysiological properties of the follicle wall in the pig ovary.

Experentia $\underline{44}, 212-214$.

GRAHAM, C. F., C. J. ELLIS, A. L. BRICE, L. J. RICHARDSON, H. MARSHLL, P. N. SCHOFIELD (1990):

Growth factors and early mammalian development.

In: Establishing a successful human pregnancy ED. R. G. Edwards, Serono Sympose. Raven Press. 
GROCHOLOVÁ, R. J. PETR, J. MAREK, O. TEPLÁ (1995):

Beneficial influence of vero cells on in vitro maturation and fertilization of bovine oocytes.

Theriogenology $\underline{44}, 199-205$.

GRUPEN, C. G., H. NAGASHIMA, M. B. NOTTLE (1995):

Cysteamine enhances in vitro development of porcine oocytes matured and fertilized in vitro.

Biol. Reprod 포, 173-178.

GURDON, J. B. (1968):

Transplanted nuclei and cell cycle differentiation.

Sci. Am. 219, 24-35.

GURDON, J. B. (1973):

Gene expression during cell differentiation.

Oxford University press, Oxford

HAFEZ, E. S. E. (1980):

Reproduction in farm animals.

Lea $\&$ Febiger, $4^{\text {th }}$ Edition, Philadelphia.

HARVEY, M. B. P. L. KAYE (1988):

Insulin stimulates protein synthesis in compacted mouse embryos.

Endocrinology 122, 1182-1184.

HAMANO, S., K. NAITO, Y. FUKUDA, Y. TOYODA (1989):

In vitro capacitation of boar ejaculated spermatozoa: Effect of conditioned media prepared from preincubated sperm suspension.

Gam. Res. 24, 483-489.

HAMANO, S., M. KUWAYAMA (1993):

In vitro fertilization and development of bovine oocytes recovered from the ovaries of individual donors: A comparision between the cutting and aspiration method.

Theriogenology 39, 703-712. 
HANCOCK, J. L. (1959):

Polyspermie of pig ova.

Anim. Prod 1, 103-106.

HAMNER, C. E. (1973):

Oviductual fluid- Composition and physiology:

In Handbook of physiology-Section 7: Endocrinology, Vol II Female reproductive System, Part 2, pp.141-151, Eds R. O. GREEP \& E. B. ASTWOOD. American Physiological Society, Washington, D.

HARRISON, R. A. P., B. MAIRET, N. G. A. MILLER (1993):

Flow cytometric studies of bicarbonate-meiated $\mathrm{Ca}^{2+}$ influx in boar sperm populations.

Mol. Reprod. Dev. 35 197-208.

HENDERSON, K. M., P. FRANCHIMONT (1983):

Inhibin production by bovine ovarian tissues in vitro and ist regulation by androgens.

J. Reprod Fert. 67, 291-298.

HENDERSON, K. M., P. FRANCHIMONT, M. J. LECOMTE-YERNA, N. HUDSON, K.

BALL (1984):

Increase of ovulation rate after active immunization of sheep with inhibin partially purified from bovine follicular fluid.

J.Endocr. 102, 305-309.

HENDRICKS, D. M., C. T. LEE (1992):

Porcine ociduct epithelial culture produce growth factor (EGF) and insulin-like growth factor (IGF) I.

Endocrine society, 1147, abstr.

HENNIES, M., E. DIETRICH, R. MÖLLER, W. HOLTZ, J. K.VOGLMAYR (1992):

Antibody titre, mating behavior and ovarian activity in goats immunized against recombinant inhibin.

Acta Endocrinol.126 Suppl. 4, 136. 
HERRLER, A., H. M BEIER (1998):

Die Beurteilung der Eizellreifung und frühen Embryonalentwicklung bei der assistierten Reproduktion.

Reproduktionsmedizin 14, 131-142.

HILLENSJO, T., C. P. CHANNING ((1980):

Gonadotrophin stimulation of steroidogenesis and cellular dispersion in cultured porcine cumuli oophori.

Gam. Res. 3, 233-240.

HIRAO, Y., T. NAGAI, M. KUBO, T. MIYANO, M. MIYAKE, S. KATO (1994):

In vitro growth and maturation of pig oocytes.

J. Reprod. Fert. 100, 333-339.

HIRATO, F., W. J. STRITTMATTER; R. AXELROD (1979):

$\beta$-adrenergic receptor agonists increase phospholipid methylation, membrane fluidity and $\beta$-adrenergic receptor-adenylate cyclase coupling.

Proc. Nat. Acad. Sci. U.S.A. $\underline{76}$, 368-372.

HOMA, S. T., C. RACOWSKY, R. W. McGAUGHEY (1986):

Lipid analysis of immature pig oocytes.

J. Reprod Fert. 77, 425-434.

HORST, VAN DER; C. J. G., H. J. G. GROOTEN (1966):

The occurrence of hypotaurine and other sulfur-containing amino acids in seminal plasma and spermatozoa of boar, bull and dog.

Biochem. Biophys.. Acta, 117, 495-497.

HUNTER, R. H. F., C. POLGE (1966):

Maturation of follicular oocytes in the pig after injection of human chorionic gonadotrophin.

Reprod. Fert. $\underline{12}$, 525-531. 
HUNTER, R. H. F. (1967):

The effects of delayed insemination on fertilization and early cleavage in the pig.

J. Reprod. Fert. 13, 133-147.

HUNTER, R. H. F., J. P. HALL (1974):

Capacitation of boar spermatozoas: The influence of post coital separation of the uterus and the fallopian tubes.

Anat. Rec. 180, 597-603.

HUNTER, A. G., R. M. MOOR (1987):

Stage-dependent effects of inhibiting ribonucleic acids and protein synthesis on meiotic maturation of bovine oocytes in vitro.

J. Dairy Sci 무, 1646-1651.

HUNTER, R. H. F. (1990):

Fertilization of pig eggs in vivo and in vitro.

Reprod. Fert., Suppl. $\underline{40}$, 211-226.

HUSSEIN, A, M., F. J. BOURNE (1984):

Immunoglobin concentrations in pig follicular fluid.

Int. J. Fertil. 29 (1), 54-57.

IM, K. S., K. W. PARK (1995):

Effects of epidermal growth factor on maturation, fertilization and development of bovine follicular oocytes.

Therigenology $\underline{44}, 209-216$.

IRITANI, A., SATO, E., Y. NISHIKAWA (1974):

Secretion rates and chemical composition of oviduct and uterine fluids in sows.

J. Anim. Sci. $\underline{39}$, 582-588. 
IRITANI, A., K. NIWA, H. IMAI (1978):

Sperm penetration in vitro of pig follicular oocytes matured in culture.

J. Reprod. Fert. $\underline{54}, 379-383$.

KANE, M. T. (1975):

Bicarbonate requirements for culture of one-cell rabbit ova to blastocyst.

Biol. Reprod. 12, 552-555.

KANE, M. T., E. W. CARNEY, J. E. ELLINGTON (1992):

The role of nutrient, peptide growth factors and co-culture cells in development of preimplantation embryos in vitro.

Theriogenology $\underline{38}, 297-313$.

KANO, K., T. MIYANO, S. KATO (1994):

Effect of oviductual epithelial cells on fertilization of pig oocytes in vitro.

Theriogenology $\underline{42}, 1061-1068$.

KAPLAN, G., S. ABREU, R. BACHVAROVA (1982):

rRNA accumulation and protein synthesis patterns in growing mouse oocytes.

J. Exp. Zool. 220, 361-370.

KAUFFOLD, P., I. THAMM (1985):

Zustandsbeurteilung von Rinderembryonen. Arbeitsanleitung für den Embryotransfer.

Forschungszentrum für Tierproduktion Dummersdorf-Rostock.

KATO, Y. Y. TSUNODA (1994):

Effects of the culture density of mouse zygotes on the development in vitro and in vivo.

Theriogenology 41, 1315-1322.

KAYE, P. L., L. B. PEMBLE, J. G. HOBBS (1986):

Protein metabolism in preimplantation mouse embryos.

Prog. Clin. Biol. Res. 217B, 103-106. 
KAYE, P. L. (1986):

Metabolic aspects of the physiology of the preimplantation embry. In: Experimental approaches to mammalian embryonic development, J. Rossant \& R. A. Pedersen (eds.) Cambridge university press, Cambridge, pp. 267-292.

KIKUCHI, K., T. NAGAI, J. MOTLIK ( 1991):

Effect of follicle cells on in vitro fertilization of pig follicular oocytes.

Theriogenology 35: 225.

KIKUCHI, K., T. NAGAI, J. MOTLIK, Y. SHIOYA, Y. IZAIKE (1993):

Effect of follicle cells on in vitro fertilization of pig follicular oocytes.

Theriogenology 39, 593-599.

KIKUCHI, K. K. NAITO, F. P. DAEN, Y. IZAIKE, Y. TOYODA (1995):

Histone $\mathrm{H} 1$ activity during in vitro fertilization of pig follicular oocytes matured in vitro.

Theriogenology $\underline{43}, 523-532$.

KOOBS, D. H. (1972):

Phosphate mediation of the crabtree and pasteur effects.

Science 178, 127-133.

KRISHER, R. L., R. M. PETTERS, B. H. JOHNSON, B. D. BAVISTER, A. E. ARCHIBONG (1989a):

Development of porcine embryos from the one-cell stage to blstocyst in mouse oviducts maintained in organ culture.

J. Exp. Zool. 249, 235-239.

KRISHER, R. L., R. M. PETTERS, B. H. JOHNSON (1989b):

Effect of oviductal condition on the development of one - cell porcine embryos in mouse or rat oviducts maintained in organ culture.

Theriogenology $\underline{32}$ (6), 885-892. 
KURZROCK, R., Z. ESTROV, M. WETZLAR, J. V. GUTTERMAN, M. TALPOZ (1991):

LIF: Not just a leukaemia inhibitory factor.

Endocr. Rev. 12, 208-217.

LABBE, J. C., A. PICARD, G. PEAUCEllier, J. C. CAVADORE, P. NURSE, M. DOREE(1989):

Purification of MPF from starfish: Identification as the H1 histone kinase p34cdc2 and a possible mechanism for its periodic activation.

Cell 57, 253-263.

LARSEN, W. J., WERT, S. E., BRUNNER, G. D. (1986):

A dramatic loss of cumulus cell gap junctions is correlated with germinal vesicle breakdown in rat oocytes.

Dev. Biol. $\underline{113}$, 517-521.

LEIBFRIED, L., N. L. FIRST (1979):

Characterization of bovine follicular oocytes and their ability to mature in vitro.

J. Anim. Sci. $\underline{48}$ (1), 76-86.

LEIBFRIED, L., N. L. FIRST (1980):

Follicular control of meiosis in the porcine oocyte.

Biol. Reprod. 23, 705-709.

LENZ, R. W., G. E. BALL, M. L. LIEBFRIED, R. L. AX, N. L. FIRST (1983):

In vitro maturation and fertilization of bovine oocytes are temperature-dependent processes.

Biol. Reprod. 29, 173-179.

LINDNER, G. M., R. W. WRIGHT (1978):

Morpgological and quantitative aspects of the development of swine embryos in vitro.

J. Anim. Sci. $\underline{46}$ (3), 711-718. 
LIU, Z., R. H. FOOTE, X. YANG (1995):

Development of early bovine embryos in coculture with KSOM and Taurine, superoxide dismutase or Insulin.

Theriogenology $\underline{44}, 741-750$.

LOPEZ, L. C., E. M. BAYNA, D. LITOFF, N. L. SHAPER, H. J. SHAPER, B. D. SHUR (1985):

Receptor function of mouse sperm surface galactosyltransferase during fertilization.

J. Cell. Biol. 101, 1501-1510.

LOUTRADIS, D., D. JOHN, A. A. KIESSLING (1987):

Hypoxanthine sauses a 2-cell block in random-bred mouse oocytes.

Biol. Reprod. 37, 311-316.

MALAYER, J. R., P. J. HANSEN, W. C. BUHI (1988):

Secretions of proteins by cultured bovine oviducts collected from estrous through early diestrous.

J. Exp. Zool. 248, 345-353.

MARQUARDT, H., G. J. TODARO, L. E. HENDERSON, S. OROSZLAN (1988):

Purification and primary structure of a polypeptide with multiplicationstimulating activity from rat liver cultures.

J. Biol. Chem. 256, 6859-6865.

MAAS, D. H. A., B. T. STOREY, L. MASTROIANNI (1977):

Hydrogen ion and carbon dioxide content of the oviductal fluid of the rhesus monkey (Macaca mulatta).

Fert. Steril. 28, 981-985.

MALENKO, G. P. (1994):

An improved method for preparing whole specimens from bovine preimplantation embryos: A technique note.

Theriogenology $\underline{41}, 1207-1210$ 
MASSAGUÉ, J., B. KELLY, C. MOTTOLA (1985):

Stimulation by insulin like growth factor is required for cellular transformation by type $\beta$ transformation growth factor.

J. Biol. Chem. 260, 4551-4554.

MASON, A. J. J. S. HAYFLICK, N. LING, F. ESH, N. UENO, S.-Y., YING, R. GUILLEMIN, H. NIALL, P. H. SEEBURG (1985):

Complementary DNA sequence of ovarian follicular fluid inhibin show precursor structure with transforming growth factor- $\beta$.

Nature London $\underline{318}, 659-663$.

MATSUI, Y., C. L. MARKERT (1971):

Cytoplasmic control of nuclear behavior during meiotic maturation of frog oocytes.

J. Exp. Zool. 177, 129-146.

MASUI, I., H. J. CLARKE (1985):

Problems of oocytes maturation and the control of chromosome cycles.

Devel. Growth Different.. 27, 295-309.

MATTIOLI, M, G. GALEATI, E. SEREN (1988a):

Effect of follicle somatic cells during pig oocyte maturation on egg penetrability and male pronucleus formation.

Gam. Res. $\underline{20}, 177-183$.

MATTIOLI, M., G. GALEATI, M. L. BACCI, E. SEREN (1988b):

Follicular factors influence oocyte fertilizability by modulating the intercellular cooperation between cumulus cells and oocyte.

Gam. Res. 21, 223-232.

MATTIOLI, M:, M. L. BACCI, G. GALEATI, E. SEREN (1989):

Developmental competence of pig oocytes matured and fertilized in vitro.

Theriogenology 31, 1201-1207. 
MATTIOLI, M., G. GALEATI, B. BARBONI, E. SEREN (1994):

Concentration of cyclic AMP during the maturation of pig oocytes in vivo and in vitro.

J. Reprod. Fert. $\underline{100}, 403-409$.

\section{MATTIOLI, M. (1994):}

Recent acquisations in pig oocyte maturation and fertilization in vitro.

Reprod. Dom. Anim. $\underline{5}$, 337-384.

MEIZEL, S., C. W. LUI, P. K. WORKING, R. J. MRSNY (1980):

Taurine and hypotaurine: their effect on motilitiy, capacitation and their acrosome reaction of hamster sperm in vitro and their presence in sperm and reproductive tract fluids of several mamals.

Develop. Growth Different. $\underline{22}, 483-494$.

McGAUGHEY, R. W. (1975):

A comparision of the fluids from small and large ovarian follicles of the pig.

Biol. Reprod. 143, 147-153.

McGAUGHEY, R. W. (1977):

The culture of pig oocytes in minimal medium, and the influence of progesterone and estradiol-17 $\beta$ on meiotic maturation.

Endocrinology 100 (1), 3945.

McGAUGHEY, R. W. (1977):

The maturation of porcine oocytes in minimal, defined culture media with varied macromolecular supplements and varied osmolarity.

Gam. Res. 20, 177-183.

\section{McGAUGHEY, D. H. MONTGOMERY, J. D. RICHTER (1979):}

Germinal vesicle configurations and patterns of polypeptide synthesis of porcine oocytes from antral follicles of different size, as related to their competency of spontaneous maturation.

J. Exp. Zool. 209, 239-254. 
MEINECKE, B., S. MEINECKE - TILLMANN (1979):

Effects of gonadotrophins on oocyte maturation and progesterone production by porcine ovarian follicles cultured in vitro.

Theriogenology 11(5), 351-359.

MEINECKE, B., H. GIPS, S. MEINECKE - TILLMANN (1982):

Zur Dynamik der präovulatorischen intrafollikulären Steroidhormonsekretion beim Schwein.

Zuchthygiene $\underline{19}$, 193-204.

MEISTER, A., M. E. ANDERSON (1983):

Gluthadione.

Ann. Rev. Biochem 52, 11-60.

MEIZEL, S., C. W. LIU, P. K. WORKING, R. J. MERSNY (1980):

Taurine and Hypotaurine: Their effects on motility, capacitation and acrosome reaction of hamster sperm in vitro and their presence in sperm and reproductive tract fluid of several mammals.

Dev. Growth. Differ. 22, 483-494 .

MICHELMANN, H. W. , A. BOGDAN, B. HINNEY (1995):

Micromorphometry and spermatozoa binding patterns of fertilized human oocytes after in-vitro fertilization.

Human. Reprod. 10, 3154-3160.

MINATO, Y., Y. TOYODA (1982):

Induction of cumulus expansion and maturation division of porcine oocyte cumulus complexes.

Jpn. J. Zootech. Sci. 포,(7), 480-487.

MIYANO, T., R. E. HIRO-OKA, K. KANO, M. MIYAKE, H. KUSUNOKI, S. KATO (1994):

Effects of hyaluronic acid on the development of 1- and 2-cell porcine embryos to the blastocyst stage in vitro.

Theriogenology 1ㅗ, 1299-1305. 
MIZOGUCHI, H., W. R. DUKELOW (1981):

Gradual fixation method for chromosomal studies of squirrel monkey oocytes after gonadotropin treatment.

J. Med. Primatol. 10, 180-186.

MOOR, R. M., I. M. CROSBY, J. C. OSBORN (1983):

Growth and maturation of mammalian oocytes.

In vitro fertilization and embryo transfer. Academic Press Inc. London, Ltd.

MOOR, R. M., I. M. CROSBY (1986):

Protein requirements for germinal vesicle breakdown in ovine oocytes.

J. Embryol. Exp. Morphol. 94, 207-220.

MOORE, G. P. M., S. LINTERN-MOORE (1987):

Transcription of mouse oocyte genome.

Biol. Reprod. 17, 865-870.

MOORE, K. H., B. S. DUNBAR, G. R. BOUSFIELD, D. N. WARD (1994):

Initial charcterization of equine inhibin.

Biol. Reprod. 1ㅗ 63-71.

MORI, T., TAKENAKA, T. NAGAI (1993):

Effects of caffeine, casein phosphopeptides and $\mathrm{Ca} 2+$ on penetration in vitro of pig oocytes matured in culture.

Theriogenology $\underline{39}, 272$.

MORI, T., A. TAENAKA, M. HIRAYAMA, H. SHIMIZU, T. NAGAI (1994):

Effect of casein phosphopeptides on penetration of boar spermatozoa to oocytes matured in culture.

Theriogenlogy $\underline{41}, 262$.

MOTLIK, J., J. FULKA (1976):

Breakdown of the germinal vesicle in pig oocytes in vivo and in vitro.

J. Exp. Zool. 198, 155-162. 
MOTLIK, J., N. CROZET, J. FULKA (1984):

Meiotic competence in vitro of pig oocytes isolated from early antral follicles.

J. Reprod. Fert. $\underline{72}$, 323-328.

MOTLIK, J., J. FULKA, J. - E. FLÉCHON ( 1986):

Changes in the intercelllar coupling between pig oocytes and cumulus cells during maturation in vivo and in vitro.

J. Reprod Fert. $\underline{76}$, 31-37.

MOTLIK, J., J. FULKA (1986):

Factors affecting meiotic competence in pig oocytes.

Theriogenology 25 (1), 87-97.

NAGAI, T., K. NIWA, A. IRITANI (1983):

Improved rates of sperm penetration in pig follicular oocytes matured in culture. Jpn. Fert. Steril.. 28, 313-318.

NAGAI, T., K. NIWA, A. IRITANI (1984):

Effect of sperm concentration during preincubation in a defined medium on fertilization in vitro of pig follicular oocytes.

J. Reprod. Fert. $\underline{70}$, 271-275.

NAGAI, T., T. TAKAHASHI, H. MASUDA, Y. SHIOYA, M. KUWAYAMA, M. FUKASHIMA, S. IWASAKI, A. HANADA (1988):

In-vitro fertilization of pig oocytes by frozen boar spermatozoa.

J. Reprod. Fert. 84, 585-591.

NAGAI, T., R. M. MOOR (1990):

Effect of oviduct cells on the incidence of polyspermy in pig eggs fertilized in vitro.

Mol. Reprod. Dev. 26, 377-382. 
NAGAI, T., T. TAKAHASHI, Y. SHIOYA, N. OGURI (1990):

Maturation and fertilization of pig follicular oocytes cultured in pig amniotic fluid.

Theriogenology 34 (2), 195-203.

NAGAI, T., J. DING, R. M. MOOR (1993):

Effect of follicular cells and steroidgenesis on maturation and fertilization in vitro of pig oocytes.

J. Exp. Zool. 266, 146-151.

NAGAO, Y., K. SAEKI, M. HOSHI, H. KAINUMA (1994):

Effects of oxygen concentration and oviductual epithelial tissue on the development of in vitro matured and fertilized bovine oocytes cultured in proteinfree medium.

Theriogenology $\underline{41}, 681-687$.

NAITO, K., Y. FUKUDA, Y. TOYODA (1988):

Effects of porcine follicular fluid on the male pronucleus formation in porcine oocytes matured in vitro.

Gam. Res. 21, 289-295.

\section{NAITO, K., Y. FUKUDA, I. ISHIBASHI (1989):}

Developmental ability of porcine ova matured in porcine follicular fluid in vitro and fertilized in vitro.

Theriogenology 31 (5), 1049-1057.

NAITO, K., M. KOSAKA, Y. FUKUDA, I. ISHIBASHI, Y. TOYODA (1990):

Analysis of factor(s) present in follicular fluids promoting male pronucleus formation ability of porcine follicular oocytes.

Jpn. J. Reprod. $\underline{36}$ (4)., 213-218.

NAKAO, H., N. NAKATSUJII (1990):

Effects of co-culture, medium components and gas phase on in vitro culture of in vitro matured and fertilized bovine embryos.

Theriogenology $\underline{33}, 591-600$. 
NASR-ESFAHANI, M. H., M. H. JOHNSON (1992):

How does transferrine overcome the in vitro block to development of mouse preimplantion embryo?

J. Reprod. Fert. $\underline{96}, 41-48$.

NARIMOTO, K., NODA, Y., SHIOTANI, M., NATSUYAMA, S., MORI, T., FUJIMOTO, K., OGAWA, K., KIM, Y. C. (1991):

Role of superoxides dismutase in the fallopian tube function: Immunohistochemical assessment of superoxide dismutase in the fallopian tube. Acta Histochem. Cytochem. 24 , 85-91.

NODA, Y., H. MATSUMOTO, Y. UMAOKA, K. TATSUMI, J. KISHI, T. MORI (1991): Involvement of superoxide radicals in the two - cell block. Mol. Reprod Dev. 28, 356-360.

O, W. - S., D. M. ROBERTSON, D. M. de KRETSER (1989):

Inhibin as an oocyte meiotic inhibitor.

Mol. and Cell. Endocrinology $\underline{62}, 307-311$.

OCAMPO, M. B., L. C. OCAMPO, T. MORI, J. UEDA, H. KANAGAWA (1994):

Timing of sequential changes in chromosome configurations during the second meiotic division and cytoplasmic events of pig oocytes matured and fertilized in vitro.

Anim. Reprod. Sci. $\underline{34}$, 281-288.

OLSON, G. E., D. W. HAMILTON (1978):

Characterization of the surface glycoproteins of rat spermatozoa. Biol. Reprod. 19, 26-35.

OSBORN, J. C., R. M. MOOR (1983):

The role of steroid signals in maturation of mammalian oocytes.

J. Steroid. Biochem. 19, 133-137. 
O’SHEA, T., M. A. HILLARD, S. T. ANDERSON, B. M. BINDON, J. K. FINDLAY, C. G. TSONIS, J. F. WILKINS (1994):

Inhibin immuniozation for increasing ovulation rate and superovulation. Theriogenology $\underline{41}, 3-17$.

PALASZ, A. T., M. B. TORNESI, J. ARCHER, R. J. MAPLETOFT (1995):

Media alternatives for the collection and freezeing of mouse and cattle embryos.

Theriogenology $\underline{44}, 705-714$.

PARRISH, J. J., SUSKO-PARRISH, J. L., WINER, M. A., FIRST, N. L. (1988):

Capacitation of bovine sperm by heparin.

Biol. Reprod. $\underline{38}$, 1171-1180.

PAUFlER, S. K., H. BADER, A: BONFERT, R. H. FOOTE, S. SALAMON, H. W. VASTERLING (1974):

Künstliche Besamung und Eitransplantation bei Tier und Mensch.

Verlag m. \& H. Schaper, Hannover

PAVASUTHIPAISIT, K., Y. KITIYANANT, C. TOCHARUS (1994):

Embryonic development of bovine oocytes fertilized by sperm microinjection: Comparision between subzonal and ooplasmic injection.

Theriogenology $\underline{41}, 270$.

PEREIRA, R. J. T. A., M. AYOUB, W. HOLTZ (1995).:

Birth of live goat kids after in vitro maturation, fertilization and culture.

Reprod. Dom. Anim. 30, 299-300.

PERREAULT, S. D., R. R. BARBEE, V. I. SLOTT (1988):

Importance of gluthadione in the acquisation and maintainance of sperm nuclear decondensing activity in the maturing hamster oocytes.

Dev. Biol. 25, 181-186. 
PETTERS, R. M., B. H. JOHNSON; M. L. REED, A. E. ARCHIBONG ( 1990):

Glucose, glutamin and inorganic phosphate in early development of the pig embryos in vitro.

J. Reprod Fert. $\underline{89}$, 269-275.

PETTERS, R. M., M. L. REED (1991):

Addition of taurine or hypotaurine to culture medium improves development of one-and two-cell pig embryos in vitro.

Theriogenology $\underline{35}, 253$.

PETTERS, R. M: (1992):

Embryo development in vitro to the blastocyst stage in cattle, pigs and sheep.

Anim. Reprod. Sci. $\underline{28}, 415-421$.

PEURA, T. T. (1993):

In vitro culture of mammalian preimplantation embryos.

Zuchthyg. 28 (4), 170-173.

PINCUS, G., E. V. ENZMANN (1935):

The comparative behavior of mammalian eggs in vivo and in vitro.

J. Exp. Med. $\underline{62}, 665-675$.

PINYOPUMMINTR, T., B. D. BAVISTER (1991):

In vitro-matured/in-vitro-fertilized bovine oocytes can develop into morulae/blastocyst in chemically defined, protein-free culture media.

Biol. Reprod. 45, 736-742.

PINYOPUMMINTR, T., B. D. BAVISTER (1994a):

Effect of gaseous atmosphere on in vitro maturation and in vitro fertilization of bovine oocytes.

Theriogenology $\underline{41}, 276$. 
PINYOPUMMINTR, T., B. D. BAVISTER (1994b):

Development of bovine embryos in a cell-free culture medium: Effects of type of serum, timing of its inclusion and heat inactivation.

Theriogenology $\underline{41}, 1241-1249$.

PINYOPUMMINTR, T., B. D. BAVISTER (1995):

Optimum gas atmosphere for in vitro maturation and in vitro fertilization of bovine oocytes.

Theriogenology $\underline{44}, 471-477$.

POIRIER, G. R., J. JACKSON (1981):

Isolation and characterization of two proteinase inhibitors from male reproductive tract of mice.

Gam. Res. $\underline{4}$, 555-569.

POLGE, C. (1982):

Embryo transplantation and preservation.

In: Control of pig reproduction, COLE, D. J. A., FOXCROFT, G. R. (Eds.), Butterworth Scientific, London, 277-291.

PRATHER, R. S., P. A. EICHEN, D. K. NICKS, M. S. PETERS (1991):

Activation of porcine oocytes matured in vitro.

Theriogenology $\underline{35}, 258$.

PRATTEN, M. K., A. M. BROOKE, S. C. BROOME, F. BECK (1988):

The effect of epidermal growth factor, insulin, transferrine on the growth promoting properties of serum depleted by repeated culture of postimplantation rat embryos.

Development 104, 137-145.

PURSEL, V. G., R. J. WALL, C. E. REXROAD, R. E. HAMMER, R. L. BRINSTER (1985):

A rapid whole-mount staining procedure for nuclei of mammalian embryos.

Theriogenology 24, 687-700. 
RACOWSKY, C., R. W. McGAUGHEY (1982):

Further studies of the effects of follicular fluid and membrana granulosa cells on the spontaneous maturation of pig oocytes.

J. Reprod. Fert. $\underline{66}, 505-512$.

RACOWSKY, C. (1985):

Effect of Forskolin on meiotic arrest and stimulation of cumulus expansion, progesterone and cyclic cyclic AMP production by pig cumulus-oocyte complexes. J. Reprod. Fert.72, 107-116.

RATH, D. (1992):

Experiments to improve in vitro fertilization techniques for in vivo-matured porcine oocytes.

Theriogenology $\underline{37}, 885-896$.

RATH, D., L. A. JOHNSON, G. R. WELCH (1993):

In vitro culture of porcine embryos: Development to blastocysts after in vitro fertilization (IVF ) with flow cytometrically sorted and unsorted semen.

Theriogenology $\underline{39}, 293$.

RATH, D. H. NIEMANN, T. TAO (1995):

In vitro maturation of porcine oocytes in follicular fluid with subsequent effects on fertilization and embryo yield.

Theriogenology 44, 529-538.

REED, M. L., M. J. ILLERA, R. M. PETTERS (1992):

In vitro culture of pig embryos.

Theriogenology 37, 95-109.

REHMANN, N., A. R. COLLINS, T. K. SUH, R. W. WRIGHT (1994):

Development of in vitro matured and fertilized bovine oocytes co-cultured with buffalo rat liver cells.

Theriogenology $\underline{41}$, 1453-1462. 
REXROAD, C. E. (1989):

Co - culture of domestic animal embryos.

Theriogenology $\underline{31}(1), 105-114$.

RIEGER, D., N. M: LOSKUTOFF, K. J. BETTERIDGE (1992):

Developmentally related changes in the uptake and metabolism of glucose, glutamin and pyruvate by cattle embryos produced in vitro.

Reprod. Fert. Dev. $\underline{4}$, 547-557.

RIEGER, D. (1992):

Relationship between energy metabolism and development of early mammalian embryos.

Theriogenology $\underline{37}, 75-93$.

ROSENKRANS, C. F., D. L. DAVIS, G. MILLIKEN (1989):

Pig blastocyst development in vitro is affected by amino acids.

J. Anim. Sci. $\underline{67}$, 1503-1508.

ROSENKRANZ, Ch. (1993):

Low temperature $\left(20^{\circ} \mathrm{C}\right)$ during transport of porcine ovaries improves in vitro maturation of COCs.

J. Reprod. Fert. Abstr.11, 118, 64.

ROTTEN, D. (1993):

Regulation of FSH synthesis and secretion.

In: Reproduction in mammals and man. Eds THIBAULT, C., M. C. LEVASSEUR, R. H. F. HUNTER, Paris, 1993.

SAITO, S., H. NIEMANN (1991):

Effects of extracellular matrices and growth factors on the development of isolated porcine blastomeres.

Biol. Reprod. 44, 927-936.

SATO, E., A. IRITANI, Y. NISHIKAWA (1978):

Rate of maturation division of pig follicular oocytes cultured in vito. Jpn J. Zootech. Sci. $\underline{49}$, 400-405. 
SATO, E., H. MIYAMOTO, S. S. KOIDE (1990):

Glycosaminoglycans in porcine follicular fluid promoting viability of oocytes in culture.

Mol. Reprod. Dev. 26, 391-397.

SATO, E., T. TANAKA, T. TAKEYA, H. MIYAMOTO, S. S. KOIDE (1991):

Ovarian glycosaminoglycans potentiate angiogenic activity of epidermal growth factor in mice.

Endocrinology 128, 2402-2406.

SCHILLING, E., H. H. DÖPKE (1978):

A Rapid diagnostic test for the viability of early cattle and rabbit embryos using Diacetyl-fluorescin.

Naturwissenschaften $\underline{65}, 658$.

SCHILLING, E., D. SMIDT (1979):

Beurteilung der Lebensfähigkeit früher Embryonalstadien beim Rind.

Tagung: „Physiologie und Pathologie der Haustiere“, München,

Zuchthygiene $\underline{14}, 86$.

SCHILLING, E., D. SMIDT, B. SACHER, S. EL KASCHAB (1979):

Diagnosis of the viability of early bovine embryos by fluorescence microscopy.

Ann. Biol. Anim. Bioch. Biophys. 19 (5), 1625-1629.

SCHINI, S. A., B. D. BAVISTER (1988):

Two-cell block to development of cultured hamster embryos is caused by phosphate and glucose.

Biol. Reprod. $\underline{39}$, 1183-1192.

SCHLIEPER, B., W. HOLTZ (1986):

Transfer of pig embryos collected by laparatomy or slaughter.

Anim. Reprod. Sci. 12, 109-114. 
SCHULTZ, R. (1987):

„Molecular aspects of oocyte growth and maturation.“

In: ROSSANT, J., R. A. PEDERSEN.Eds.,Experimental approaches to mammalian embryonic development, Univ. Press, Cambridge, 1987, 195-237.

SCOTT, R., H. QUIGG, A. TROUNSON, C. TSONIS, J. K. FINDLAY (1980):

Inhibin in ovine follicular fluid.

Proc. Endocr. Soc. Aust. 23, 76 (Abstr.).

SALING, P.M. (1989):

Mammalian sperm interaction with extracellular matrices of the egg.

Reprod. Biol. 11, 339-388.

SESHAGIRI, P. B., B. D. BAVISTER (1989):

Phosphate is required for inhibition by glucose of development of hamster 8-cell embryos in vitro.

Biol. Reprod. 무, 607-614.

SINGH, B., D. T. ARMSTRONG (1994):

Localization of epidermal growth factor and its receptor in the porcine ovarian follicle, and its effects on in vitro maturation (IVM) and fertilization (IVF) of porcine oocytes.

Therigenology $\underline{41}, 295$.

SMITH, A. G., M. L. HOOPER (1987):

Buffalo rat liver cells produce a diffusable activity which inhibits the differentiation of murine embryonal carcinoma and embryonic stem cells.

Cell $\underline{31}, 11-24$.

SPINDLE (1995):

Beneficial effects of taurine on mouse zygotes developing in protein-free culture medium.

Theriogenology $\underline{44}, 761-772$. 
STAIGMILLER, R. B., R. M. MOOR (1984):

Effect of follicle cells on the maturation and development competence of ovine oocytes matured outside the follicle.

Gam. Res. $\underline{9}, 221-229$.

STOUFFER, R. L., G. D. HODGEN (1980):

Induction of luteal phase defects in rhesus monkeys by follicular fluid administration at the onset of menstrual cycle.

J. Clin. Endocrinol. Metab. 1, 669-671.

STUBBS, C. D., A. D. SMITH (1984):

The modification of mamalian membrane polyunsaturated fatty acid composition in relation to membrane fluidity and function.

Biochem. Biophys. Acta 779, 89-137.

SZÖLLÖSI, D. (1980):

Interaction between oocyte and follicle in vivo.

Proc. 9th Int. Cong. Anim. Reprod. Artif. Insem., Madrid, 95-99.

SZÖLLÖSI, D. (1993):

"Oocyte maturation.“

In: THIBAULT, C., M. C. LAVASSEUR, R. H. F. HUNTER: Reproduction in mammals and man, 1993, Ellipses, Paris.

SUZUKI, K., T. MORI, M YAMAGUCHI, H. SHIMIZU (1994a):

High potassium concentration accelerate pig sperm ability to penetrate oocytes in vitro.

Theriogenology $\underline{41}, 308,1994$.

SUZUKI, K., M. EBIHARA, T. NAGAI, N. G. E. CLARKE, R. A. P. HARRISON (1994b): Importance of Bicarbonate $/ \mathrm{CO}_{2}$ for fertilization of pig oocytes in vitro and synergism with caffeine.

Reprod. Fert. Dev. $\underline{6}, 221-227$. 
TAJIMA, Y., N. OKAMURA, Y. SUGITA (1987):

The affecting effect of bicabonate on sperm motility and respiration at ejaculation.

Biochem. Biophys. Acta. 924, 519-529.

TAKAHASHI, Y, FIRST, N. L. (1992):

In vitro development of bovine one-cell embryos: Influence of glucose, lactate, pyruvate, amino acids and vitamins.

Theriogenology 37, 963-978.

TARKOWSKI, A. K. (1966):

An air - drying method for chromosome preparations from mouse eggs.

Cytogenetics $\underline{5}, 394-500$.

THIBAULT, C., GERARD, M., MENEZO, Y. (1975):

Preovulatory and ovulatory mechanism in oocyte maturation.

J. Reprod. Fert. 45, 605-610.

THIBAULT, C., D. SZÖLLÖSI, M. GÉRARD (1987):

Mammalian oocyte maturation.

Reprod. Nutr. Develop. 27 (5), 865-896.

THIBODEAUX, J. K., J. D. ROUSSEL, L. L. GOODEAUX, Y. MENEZO, M. A. DIETRICH, R. A. GODKE (1991a):

The effect of culture media on in vitro growth and proliferation of bovine uterine epithelial cells.

Theriogenology 35: 283.

THIBODEAUX, J. K., L. L. GOODEAUX, J. D. ROUSSEL, Y.MÉNÉZO, G. F. AMBORSKI, J. D. MOREAU, R. A. GODKE (1991b):

Effects of stage of the bovine oestrus cycle on in vitro characteristics of uterine and oviductal epithelial cells.

Hum. Reprod. $\underline{6}$ (6), 751-760. 
THIBODEAUX, J. K., M. W. MYERS, S. G. PROUGH, K. L. WHITE (1995):

Effect of a serum extender containing growth factors on development of IVM and IVF bovine embryos.

Theriogenology $\underline{44}, 423-432$.

TODOROV, J., G. LEIDING, R. HAHN, J. HAHN (1993):

Über den Einfluß bestimmter Serumzusätze auf das Wachstum in vitro befruchteter Eizellen.

Persönliche Mitteilungen, 1993 in: BARG, CH. K. (1994): Einfluß der Seruminaktivierung und Mediumerneuerung auf die in vitro-Entwicklung von Embryonen. Diplomarbeit der Agrarwissenschaften an der Georg-AugustUniversität, Göttingen.

TÖPFER-PETERSEN, E., M. ENSSLIN, D. WABERSKI (1996):

Kapazitation. Eine kurze Übersicht.

Fertilität $\underline{12}$, 183-189.

TORRES, C. R., D. RATH (1992):

In vitro culture of porcine embryos to the blastocyst stage after in vivo or in vitro fertilization.

Theriogenology $\underline{37}, 283$.

TROUNSON, A. (1992):

The production of ruminant embryos in vitro.

Anim. Reprod. Sci.28: 125-137.

TROUNSON, A., GARDNER, D. K. (1993):

Handbock of in vitro fertilization.

CRC Press, Inc.,2000 Corporate Blvd., N. W., Boca Raton, Florida, 33431.

TROUNSON, A., D. PUSHETT, L. J. MACLELLAN, I. LEWIS, D. K. GARDNER (1994):

Current status of IVM/IVF and embryo culture in humans and in farm animals.

Theriogenology $\underline{41}, 57-66$. 
TSAFARI, A., C. P. CHANNING (1975):

Influence of follicular maturation conditions on the meiosis of pig oocytes in vitro.

J. Reprod Fert. $\underline{43}$, 149-152.

VAJTA, G., Z. MACHÁTY, Z. Z. BÁRÁNDI, A. SOÓS, L. SOLTI (1991):

Transfer of in vitro fertilizes and cultivated swine embryos.

Theriogenology $\underline{35}, 289$.

VAN INZEN, W. G., A. E. P. VAN STEKELENBURG-HAMERS, S. M. WEIMA. T. A. M. KRUIP, M. M. BEVERS, C. L. MUMMERY (1995):

Culture of bovine embryos to the blastocyst stage using buffalo rat liver (BRL) cells.

Theriogenology $\underline{43}, 723-738$.

VANSTEENBRUGGE, A., A. VAN LANGENDONCKT, C. SCUTENAIRE, A. MASSIP, F. DESSY (1994):

In vitro development of bovine embryos in buffalo rat liver or bovine oviductconditioned medium.

Theriogenology $\underline{42}, 931-940$.

VANDERHYDEN, B. C. (1993):

Species differences in the regulation of cumulus expansion by an oocyte - secreted factor(s).

J. Reprod Fert. $\underline{98}$, 219-227.

VISHWAKARMA, P. (1962):

The $\mathrm{pH}$ and bicarbonate-ion content of the oviduct and uterine fluids.

Fert. Steril. 13, 481-485.

VIUFF, D., V. MADISON, P. HYTTEL, B. AVERY, T. GREVE (1991):

Fluorescent intravital staining of bovine oocytes and zygotes.

Theriogenology $\underline{35}, 291$. 
VOELKEL, S. A., Y. X. HU (1992):

Effect of gas atmosphere on the development of one-cell bovine embryos in two culture systems.

Theriogenology $\underline{37}, 1117-1131$.

WANG, W. H.M. UCHIDA, K. NIWA (1992):

Effect of follicle cells on in vitro penetration of pig oocytes by cryopreserved, ejaculated spermatozoa.

J. Reprod. Dev. $\underline{8}, 125-131$.

WANG, W. H., K. NIWA, K. OKUDA (1991):

In vitro penetration of pig oocytes matured in culture by frozen-thawed ejaculated spermatozoa.

J. Reprod. Fert. $\underline{93}$, 491-496.

WANG, W.-H., ABEYDEERA, L. R., OKUDA, K., NIWA, K. (1994):

Penetration of porcine oocytes during maturation in vitro by cryopreserved, ejaculated spermatozoa.

Biol. Reprod. 무, 510-515.

WANG, W. H., L. R. ABEYDEERA, L. R. FRASER, K. NIWA (1995):

Functional analysis using chlortetracycline fluorescence and in vitro fertilization of frozen thawed ejaculated boar spermatozoa incubated in a protein-free chemically definde medium.

J. Reprod. Fert. 104, 305-313.

WALKER, S. K., R. J. LAMPE, R. F. SEAMARK (1989):

Culture of sheep zygotes in synthetic oviduct fluid medium with different concentrations of sodium bicarbonate and HEPES.

Theriogenology $\underline{32}$, 797-805.

WASSARMAN, P. M., S. C. MROZAK (1981):

Dev. Biol. $\underline{84}, 364$. 
WASSARMAN, P. M., J. D. BLEIL, S. M. CASCIO, M. J. LaMARCA, G. E. LETOURNEAU, S. C. MROZAK, R. M. SCHULTZ (1981):

In: Bioregulators of reproduction (G. Jagiello und H. J. Vogel, eds), pp 119150.Academic press, New York und London.

WATSON, A. J., A. HOGAN, A. HAHNEL, K. E. WIEMER, G. A. SCHULTZ (1992):

Expression of growth factor ligand and receptor genes in the preimplantation bovine embryo.

Mol. Reprod. Dev. 31, 87-95.

WILSON, W. L., G. OLIPHANT (1987):

Isolation and biochemical characterization of the subunits of the rabbit sperm acrosome stabilizing factor.

Biol. Reprod. 37, 159-169.

WEIGL, A., BREM, G., (1985):

In-vitro-Reifung boviner Oozyten und mögliche Anwendungsbereiche

Humanmedizinische Gemeinschaftstagung, Berlin.

WEISMAN, D. L., H. M. HENDRICKS, D. M. EBERHARDT, W. C. BRIDGES (1992):

Identification and content of insulin-like growth factors in porcine oviductual fluid.

Biol. Reprod. $\underline{47}$, 126-132

WERT, S., W. J. LARSEN (1988):

Meiotic resumption and gap junction modulation in the culture cumulus-oocyte complex.

Gam. Res. 22, 143-162.

WESTERGAARD, L. G. (1988):

Intrafollicular factors regulating human ovarian follicular development and oocyte meiosis.

Danish Med. Bull. 35 (3),270-281. 
WILLIAMS, W. L. (1972):

Biochemestry of capacitation of spermatozoa.

In: Biology of mammalian fertilization, 43-60, K. S. MOGHISSI, E. S. E. HAFEZ (eds.), C. C. THOMAS, Springfield, I11.

WISE, T., U. SÜSS, G. STRANZINGER, K. WUTHRICH, R. R. MAURER (1994):

Cumulus and oocyte maturation and in vitro and in vivo fertilization of oocytes in relation to follicular steroids, prolactin and gycosaminoglycans throughout the estrous period in superovulated heifers with normal LH surge, no detectable surge, and progestin inhibition of LH surge.

Dom. Anim. Endocrinol. 11 (1), 59-86.

WHITE, K. L., K. HEHNKE, F. RICKORDS, L. L. SOUTHERN, D. L. THOMPSON, T. C. WOOD (1989):

Early embryonic development in vitro by coculture with oviductal epithelial cells in pigs.

Biol. Reprod. $\underline{41}$, 425-430.

WHITMORE, H. L., L. F. ARCHBALD (1977):

Demonstration of quantitation of immunoglobins in bovine serum, follicular fluid and uterine vaginal secretions with reference to bovine viral diarrhoea and infectious bovine rhinotracheitis.

Am. J. Vet. Res. 38, 455.

WHITTINGHAM, D. G., J. D. BIGGERS (1968):

Development of zygotes in cultured mouse oviducts. I The effect of varying oviductal conditions.

J. Exp. Zool. 169, 391.

WIEMER, K. E., J. COHEN, G. F. AMBORSKI, G. WRIGHT, S. WIKER, L. MUNYAKAZI, R. A. GODKE (1989):

In vitro development and implantation of human embryos following culture on fetal bovine uterine fibroblast cells.

Hum. Reprod. $\underline{4}, 595-600$. 
WISEMAN, D. L.,HENDRICKS, D. M., EBERHARDT, D. M., BRIDGES, W. C. (1992):

Identification and content of insulin-like growth factors in porcine oviductual fluid.

Biol. Reprod. 47, 126-132.

WU, R. (1965):

Control mechanism of glycolysis in Ehrlich Ascites tumor cells.

J. Biol. Chem 240, 2827-2832.

WURTH, Y. A., W. I. VAN DER ZEE-KOTTING, S. J. DIELEMAN, M. M. BERVERS, TH. A. M. KRUIP (1994):

Presence of mitotic cells: a parameter of embryo quality.

Anim. Reprod. Sci. 포, 173-182.

YANAGIMACHI, R., G. L. NICOLSON, Y. D. NODA, M. FUJIMOTO (1973):

Electron microscopic observations on the distribution of acidic anionis residues in hamster spermatozoa and eggs before and during fertilization.

J. Ultrstruct. Res. $\underline{43}, 344-353$.

YANAGIMACHI, R. (1988):

Mammmalian fertilization.

The pysiology of reproduction in : E. KNOBIL, J. NEILL et al., Raven press, New York., 135-185.

YANAGIMACHI, R. (1989):

Sperm capacitation and gamete interaction.

J. Reprod. Fert., Suppl. $\underline{38}$, 27-33.

YOSHIDA, M. (1987):

In vitro fertilization of pig oocytes matured in vivo.

Jpn. J. Vet. Sci. $\underline{49}$ (4), 711-718.

YOSHIDA, M. (1993):

Role of gluthdione in the maturation and fertilization of pig oocytes in vitro.

Mol. Reprod. Dev. 35, 76-81. 
YOSHIDA, M., K. BAMBA, Y. KOJIMA (1989):

Effects of gonadotrophins and estradiol - $17 ß$ on the timing of nuclear maturation and cumulus mass expansion in pig oocytes cultured in vitro.

Jpn. J. Anim. Reprod 35 (2), 86-91.

YOSHIDA, M., Y. ISHIZAKI, H. KAWAGISHI (1990):

Blastocyst formation by pig embryos resulting from in - vitro fertiliztion of oocytes matured in vitro.

J. Reprod. Fert. $\underline{88}, 1-8$.

YOSHIDA, M., Y. ISHIZAKI, H. KAWAGISHI, K. BAMBA, Y. KOJIMA (1992):

Effects of pig follicular fluid on maturation of pig oocytes in vitro and on their subsequent fertilizing and development capacity in vitro.

J. Reprod. Fert. 95, 481-488.

YOSHIDA, M., Y. MIZOGUCHI, K. ISHIGAKI, T.KOJIMA, T. NAGAI (1993):

Birth of piglets from in vitro fertilization of pig oocytes matured in vitro.

Theriogenology $\underline{39}$, 1303-1311.

YOUNGS, C. R., T. J. KNIGHT, S. M. BATT, D. C. BEITZ (1994):

Phospholipid, choloesterol, triacylglycerol, and fatty acid composition of porcine blastocysts.

Therigenology $\underline{41}, 343$.

ZAIGLER, J. S., J. L. LEPE-ZUNIGA, B. VISTICA, I. GREY (1985):

Analysis and cytotoxic effects of light exposed HEPES-containing culture medium.

In vitro Cell Dev. Biol. 21, 282-287.

ZHANG, X., D. T. ARMSTRONG, (1990):

Presence of amino acids and insulin in a chemically defined medium improves development of 8-cell rat embryos in vitro and subsequent implantation in vivo. Biol. Reprod. 42, 662-668. 
ZHANG, L., E. G. BLAKEWOOD, R. S. DENNISTON, R. A. GODKE (1991):

The effect of insulin on maturation and development of in vitro fertilized bovine oocytes.

Theriogenology $\underline{35}, 301$.

ZHENG, Y. S., M. A. SIRARD (1992):

The effect of sera, bovine serum albumin and follicular cells on in vitro maturation and fertilization of porcine oocytes.

Theriogenology $\underline{37}, 779-790$. 


\section{Anhang}

Zusammenstellung der Medien für die IVF beim Schwein

Ovarientransportmedium* ${ }^{*}$, Phosphate buffered saline (PBS), pH 7,2-7,4; 280 $\mathrm{mOsmol} / \mathrm{kg}$

$\mathrm{NaCl}$

$8,0 \mathrm{~g}$

$\mathrm{KCl}$

$0,2 \mathrm{~g}$

$\mathrm{MgCl}_{2}$ × $6 \mathrm{H}_{2} \mathrm{O}$

$0,1 \mathrm{~g}$

$\mathrm{CaCl}_{2}$ wasserfrei**

$0,1 \mathrm{~g}$

$\mathrm{Na}_{2} \mathrm{HPO}_{4}$

$1,0 \mathrm{~g}$

$\mathrm{NaH}_{2} \mathrm{PO}_{4} \times \mathrm{H}_{2} \mathrm{O}$

$0,15 \mathrm{~g}$

$\mathrm{KH}_{2} \mathrm{PO}_{4}$

$0,2 \mathrm{~g}$

Penicillin/Streptomycin

5ml (10000 I.E/ml Penicillin, 10000 I.E.

Streptomycin)

auf $1000 \mathrm{ml}$ Aqua Bidest

* Ovarientransport für die Oozytengewinnung bei $37^{\circ} \mathrm{C}$

Ovarientransport für die Gewinnung von Follikelflüssigkeit bei $4^{\circ} \mathrm{C}$

** wird nach dem Autoklavieren als Stocklösung zufiltriert

Oozytengewinnungs- und Waschmedium* ${ }^{*}$ PBS; $\mathrm{pH}$ 7,4, $285 \mathrm{mOsm} / \mathrm{kg}$

$\begin{array}{ll}\mathrm{NaCl} & 8,0 \mathrm{~g} \\ \mathrm{KCl} & 0,2 \mathrm{~g} \\ \mathrm{MgCl}_{2} \times 6 \mathrm{H}_{2} \mathrm{O} & 0,1 \mathrm{~g} \\ \mathrm{CaCl}_{2} \text { wasserfrei** } & 0,1 \mathrm{~g} \\ \mathrm{Na}_{2} \mathrm{HPO}_{4} & 1,0 \mathrm{~g} \\ \mathrm{NaH}_{2} \mathrm{PO}_{4} \times \mathrm{H}_{2} \mathrm{O} & 0,15 \mathrm{~g} \\ \mathrm{KH}_{2} \mathrm{PO}_{4} & 0,2 \mathrm{~g} \\ \mathrm{Penicillin}_{\text {S Streptomycin }} & 5 \mathrm{ml} \text { (10000 I.E./ml Penicillin, } 10000 \text { I.E. } \\ & \text { Streptomycin) } \\ \text { FKS } & 2 \%\end{array}$

auf $1000 \mathrm{ml}$ Aqua Bidest, bei $5^{\circ} \mathrm{C}$ für 4 Wochen aufbewahrt *Steril filtriert in $100 \mathrm{ml}$ Portionen 
Oozytenmaturationsmedium ${ }^{*}$, TCM199**, $\mathrm{pH} 7,4,280 \mathrm{mOsmol} / \mathrm{kg}$

$\begin{array}{ll}\text { Na-Pyruvat } & 0,26 \mathrm{mM} \\ \text { Glucose } & 0.5 \mathrm{mM} \\ \text { Transferrin } & 5 \mu \mathrm{g} / \mathrm{ml} \\ \text { Insulin } & 5 \mu \mathrm{g} / \mathrm{ml} \\ \text { Na-Selenit } & 5 \mathrm{ng} / \mathrm{ml} \\ \text { hCG-Ekluton } & 2 \mathrm{I} . \mathrm{E} / \mathrm{ml} \\ \text { PMSG-Intergonan } & 5 \mathrm{I} . \mathrm{E} / \mathrm{ml} \\ \text { Serum/Serumanaloga } & 10 \%\end{array}$

auf $10 \mathrm{ml}$ TCM199 ohne HEPES,

*je nach Versuchansatz mit verschiedenen Serumtypen oder Follikelflüssigkeit zujeweils $10 \%$ versetzt, Steril filtriert, nur frisch angesetzt benutzt.

**9,9g TCM199-Pulver+ 2,2g NaHCO3 auf 11 Ampuva, steril filtiert, für 4 Wochen bei $8^{\circ} \mathrm{C}$ aufbewahrt

Spermawaschmedium, NaCL, pH 7,2, $280 \mathrm{mOsmol} / \mathrm{kg}$

$\begin{array}{ll}\mathrm{NaCl} & 9,0 \mathrm{~g} \\ \mathrm{BSA} & 1,0 \mathrm{~g} \\ \text { Kanamycin } & 70 \mu \mathrm{g} / \mathrm{ml}\end{array}$

auf 1000 ml Ampuva

Steril filtriert und in $100 \mathrm{ml}$ Portionen für 4 Wochen bei $4^{\circ} \mathrm{C}$ aufbewahrt

Spermakapazitationsmedium, TCM199, pH 7,8; $305 \mathrm{mOsmol} / \mathrm{kg}$

$\begin{array}{ll}\text { Ca-Laktat } & 0,09 \mathrm{~g} \\ \text { Na-Pyruvat } & 0,01 \mathrm{~g} \\ \text { D-Glucose } & 0,055 \mathrm{~g} \\ \text { Kanamycin } & 7,0 \mu \mathrm{g} \\ \text { FCS } & 12 \%\end{array}$

auf $50 \mathrm{ml}$ TCM199; steril filtriert und nur frisch angesetzt verwendet 
Fertilisationsmedium, TCM199, $\mathrm{pH}$ 7,8, 300mOsmol

$\begin{array}{ll}\text { Ca-Laktat } & 0,09 \mathrm{~g} \\ \text { Na-Pyruvat } & 0,01 \mathrm{~g} \\ \text { D-Glucose } & 0,055 \mathrm{~g} \\ \text { Kanamycin } & 7,0 \mu \mathrm{g} \\ \text { Caffeine } & 0,0135 \mathrm{~g} \\ \text { FCS } & 12 \%\end{array}$

auf $50 \mathrm{ml}$ TCM199; steril filtriert und nur frisch angesetzt verwendet

**9,9g TCM199-Pulver+ 2,2g NaHCO3 auf 11 Ampuva, steril filtiert, für 4 Wochen bei $8^{\circ} \mathrm{C}$ aufbewahrt

Anzucht- und Erhaltungsmedium für Eileiterzellen, DMEM, pH 7,4

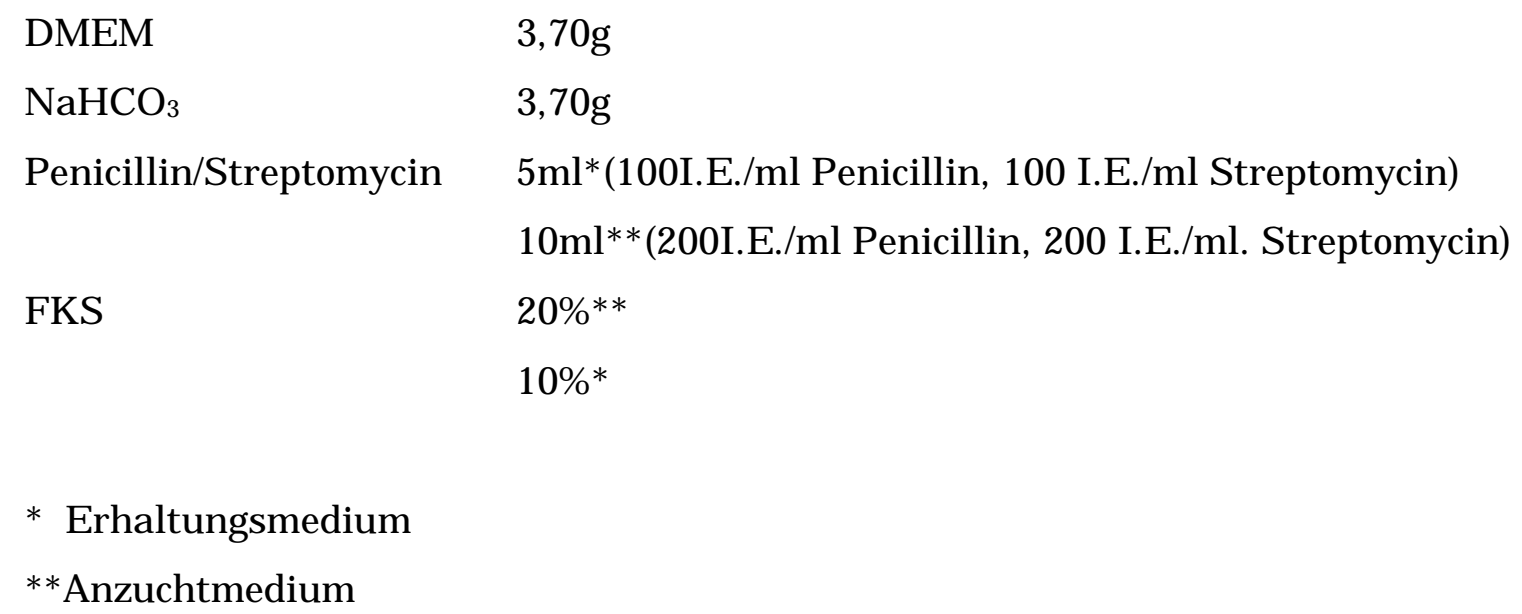


Einfriermedium für Eileiterzellen, DMEM

$\begin{array}{ll}\text { DMEM } & 1,34 \mathrm{~g} \\ \text { FKS } & 10 \% \\ \text { DMSO } & 10 \mathrm{ml} \\ \text { Glukoselösung(20\%ig) } & 0,5 \mathrm{ml} \\ \text { Penicillin/Streptomycin } & 1,0 \mathrm{ml}\end{array}$

auf $100 \mathrm{ml}$ Ampuwa, in $5 \mathrm{ml}$ Portionen steril filtriert, bei $-20^{\circ} \mathrm{C}$ aufbewahrt

Embryokulturmedium, NCSU23, $\mathrm{pH} 7,4,285 \mathrm{mOsmol}$

a) Basislösung

$\begin{array}{ll}\mathrm{NaCl} & 3,3525 \mathrm{~g}^{*} \\ \mathrm{KCl} & 0,178 \mathrm{~g}^{*} \\ \mathrm{CaCl} 2 & 0,0945 \mathrm{~g}^{*} \\ \mathrm{KH} 2 \mathrm{PO} 4 & 0,081 \mathrm{~g} * \\ \mathrm{MgSO} 4 x 7 \mathrm{H} 2 \mathrm{O} & 0,147 \mathrm{~g}^{*} \\ \mathrm{NaHCO} 3 & 1,053 \mathrm{~g}^{*} \\ \text { Phenolrot } & 1 \%\end{array}$

Diese Komponenten auf $500 \mathrm{ml}$ Ampuva steril filtriert in $100 \mathrm{ml}$ Portionen für 4 Wochen bei $5^{\circ} \mathrm{C}$ aufbewahrt

b)Basislösung mit Zusätzen

$\begin{array}{ll}\text { D-Glucose } & 0,03 \mathrm{~g} \\ \text { Glutamin } & 0,0044 \mathrm{~g} \\ \text { Taurin } & 0,026 \mathrm{~g} \\ \text { Hypotaurin } & 0,016 \mathrm{~g} \\ \text { Insulin } & 5 \mu \mathrm{g} / \mathrm{ml} \\ \text { Transferrin } & 5 \mu \mathrm{g} / \mathrm{ml} \\ \text { Na-Selenit } & 5 \mathrm{ng} / \mathrm{ml} \\ \text { Kanamycin } & 2,1 \mu \mathrm{g} \\ \text { BSA } & 0,4 \% \\ \text { FCS } & 10 \%\end{array}$

auf $30 \mathrm{ml}$ Basislösung, steril filtriert mit und ohne Feederlayer nur frisch verwendet. 


\section{Reagenzien, Verbrauchsmaterial und Geräte}

\section{Reagenzien}

TCM 199,

$\mathrm{NaCl}$

$\mathrm{KCl}$,

$\mathrm{CaCl}_{2} \times 2 \mathrm{H}_{2} \mathrm{O}$

$\mathrm{MgCl}_{2} \times 6 \mathrm{H}_{2} \mathrm{O}$

$\mathrm{MgSO}_{4} \times 7 \mathrm{H}_{2} \mathrm{O}$,

$\mathrm{KH}_{2} \mathrm{PO}_{4} \times \mathrm{H}_{2} \mathrm{O}$,

$\mathrm{NaH}_{2} \mathrm{PO}_{4}$,

$\mathrm{Na}_{2} \mathrm{HPO}_{4}$,

$\mathrm{NaHCO}_{3}$;

HEPES;

Insulin-Transferrin-Na-selenit

Ca-Laktat

D-Glucose

Caffeine

Na-Pyruvat,

Glutamin

Kanamycin,

Penicillin/Streptomycin

PMSG

hCG

BSA,

FKS

Taurin,

Hyoptaurin,

Insulin/Transferrin/Na-Selenit

Ampuva

Phenolrot,

FDA

Hoechst A 33342
Sigma, Deisenhofen, ～\# M 5017

Sigma, Deisenhofen, \# S 5886, Embryo tested

Sigma, Deisenhofen, \# P 5405, Embryo tested

Sigma, Deisenhofen, \# C 7902, Embryo tested

Sigma, Deisenhofen, \# M 2393, Embryo tested

Sigma, Deisenhofen, \# M 2643, Embryo tested

Sigma, Deisenhofen, \# P 5655, Embryo tested

Sigma, Deisenhofen, \# S 5011, Embryo tested

Sigma, Deisenhofen, \# S 5136, Embryo tested

Sigma, Deisenhofen; $\quad$ \# S 5761, Embryo tested

Sigma, Deisenhofen; \# H 9136, Embryo tested

Sigma, Deisenhofen \# I1884, Embryo tested

Sigma, Deisenhofen, ～\# L 4263

Sigma, Deisenhofen, \# G 6152, Embryo tested

Sigma, Deisenhofen \# 0750

Sigma, Deisenhofen, \# \#4562, Embryo tested

Sigma, Deisenhofen, \# G 5763, Embryo tested

Sigma, Deisenhofen, \# K 0129

Gibco, Eggenstein

Ovogest , Intervet, Tönisvorst

Intergonan , Intervet, Tönisvorst

Sigma, Deisenhofen, \# A 3311, Embryo tested

Gibco, Eggenstein

Sigma, Deisenhofen, \# T 7146

Sigma, Deisenhofen

Sigma, Deisenhofen, ～\# I 1884

Fresenius, Bad Homburg

Sigma, Deisenhofen, ～\# P3532

Sigma, Deisenhofen, \# F-7378

Sigma, Deisenhofen, \# H 6024 
Giemsa

DPX

Lacmoid

Hyaluronidase,

Mineralöl,

Essigsäure

Alkohol

Stresnil

Hypnodil

Tardomycel

\section{Verbrauchsmaterialien}

Einmalplasikspritzen

Spritzenfilter 0,2 $\mu \mathrm{m}$

$10 \mathrm{ml}$ Zentrifugenröhrchen

Kryoröhrchen

Kanülen

Pipettenspitzen

Petrischalen ( $100 \times 10 \mathrm{~mm} ; 55 \times 10 \mathrm{~mm} ; 35 \times 10 \mathrm{~mm})$

Vierlochschalen

Deckgläschen

Objektträger

Operationsfaden Syntacord EP 3

Operationsabdecktuch Secu-Drape $75 \times 75$

Zellkulturflaschen $\left(175 \mathrm{~cm}^{2}\right)$
Merck, Darmstadt

Gurr BDH, England

Sigma, Deisenhofen, ～\# L 7512

Sigma, Deisenhofen, \# H 4272

Sigma, Deisenhofen, $\quad$ \# 8410

Merck, Darmstadt

Merck, Darmstadt

Janssen, Neuß

Janssen, Neuß

Bayer AG, Leverkusen
Braun, Melsungen

Sarstedt, Nümbrecht

Sarstedt, Nümbrecht

Sarstedt, Nümbrecht

Braun, Melsungen

GLW, Würzburg

Greiner, Solingen

Nunclon Delta, GLW, Würzburg

Ochs, Bovenden

Ochs, Bovende $\mathrm{n}$

Beyverts, Berlin

Sengewald GmbH, Rohrdorf

Falcon, Becton Dickinson, England

\section{Geräte}

Stereolupe M8

Inverses Mikroskop
Wild Heerbrugg, Schweiz

Leitz, Wetzlar 
Wärmeplatten

Laminar Flow Steag,

Wasserbad D1

Brutschrank

Zentrifuge

Präzisionswaage 2007 MP6

Osmometer Osmomat 030

Digital-pH-Meter 643

pH-Sonde Ingold

Fluoreszenzmikroskop Axioscop

Fotoanlage M80

Variopetten,

Autoklav

Magnetrührer

Schüttler
Medax Nagel KG, Kiel

Rettberg, Göttingen

Haake

Water Jacketed Inkubator, Firma ScientificUSA,

Labotect, Göttingen

Labofuge II, Hereaus, Osterode

Sartorius, Göttingen

Schütt, Göttingen

WTW, Weilheim, Schütt, Göttingen

Steinbach, Taunus, Schütt, Göttingen

Zeiss, Göttingen

Zeiss Göttingen

Eppendorf, Hamburg

KSG 112, Schütt, Göttingen

Hamag Ret, Rettberg, Göttingen

Mixomat, Boskamp Geräte Bau KG, Hersel, Bonn 
Herrn Prof. Dr. W. Holtz möchte ich für die Überlassung des interessanten Themas, der Möglichkeit zur Erlernung qualifizierter Methoden sowie der Unterstützung bei der Planung und Durchführung der Versuche recht herzlich danken.

Großer Dank gilt Herrn Prof. Dr. H.W. Michelmann für die Übernahme des Korreferates dieser Arbeit sowie für die ergiebigen Gespräche und Diskussionen, die das Entstehen der Arbeit in großem Maße beeinflußt haben.

Erste Ideen und Anregungen dieses Themas wurden von Frau Dr. E. Dietrich ins Leben gerufen. Auch hat sie dafür Sorge getragen, Herrn W. T. Huang in die Arbeitsgruppe zu integrieren, dessen große Erfahrung auf dem Gebiet der porcinen IVF diese Arbeit in ihrer Entstehungsweise gefördert hat. Beiden bin ich sehr dankbar.

Frau Prof. Dr. rer. nat. I. Probst möchte ich ebenfalls meinen besonderen Dank für die freundschaftliche Zusammenarbeit und den Gedankenaustausch aussprechen.

Ohne H. Füllgrabe, die sich durch ihr gewissenhaftes Engagement und jederzeit bereitwillige Hilfe auszeichnet, wäre die Durchführung der Versuche gerade in der letzten Phase der Arbeit nicht möglich gewesen. Ich möchte ihr hierfür meinen außerordentlichen Dank aussprechen.

Für die schnelle und hochqualifizierte Hilfe bei der statistischen Ausarbeitung möchte ich Herrn Dr. H. Brandt ganz herzlich danken.

Den Kollegen und Kolleginnen der Abteilung Fortpflanzungsbiologie möchte ich für die freundschaftliche und familiäre Arbeitsatmosphäre danken.

Die Arbeit wurde im Zeitraum von 1992-1994 durch die Dr. Karl-Eibl-Stiftung finanziell gefördert, der ich daher zu großem Dank verpflichtet bin.

$\mathrm{Zu}$ guter letzt aber deshalb nicht minder möchte ich meinen Eltern für meine Ausbildung, ihr Vertrauen und jegliche Unterstützung danken. Besonderer Dank gilt meinem Mann, Henning Ropeter, der mich gerade in der langen Phase der Ausarbeitung dieser Arbeit immer wieder motiviert und unterstützt hat 


\section{Lebenslauf}

Name

Geburtsdatum,-ort

Eltern

Familienstand

Staatsangehörigkeit

Schulen

Studium

Tätigkeiten nach dem Studium:
Manuela Ropeter-Scharfenstein

17. November 1966 in Altenkirchen / Westerwald Werner Scharfenstein, KFZ - Elektriker - Meister

Barbara, geb. Großhennig, Hausfrau

verheiratet, 1 Tochter

deutsch

1974 - 1978 Grundschule Herberhausen

1978 - 1986 Theodor - Heuss - Gymnasium

Abschluß : Allgemeine Hochschulreife

1986 - 1988 Georg - August - Universität

Göttingen, Vordiplom.

1988-1989 Landwirtschaftliches Praktikum

1989 - 1992 Georg - August - Universität

Göttingen

Abschluß : Diplom - Agrar - Ingenieur

Fachrichtung : Tierproduktion

1992-1995 Wissenschaftliche Mitarbeiterin am Institut für Tierzucht und Haustiergenetik der Universität Göttingen, Arbeitsgruppe Fortpflanzung und Biotechnik seit 1995 Leiterin des Labors für Reproduktionsmedizin der Praxis Dres. F-J.Algermissen, P.Justus und G.Wilke in Hildesheim 
